Prepared in cooperation with the

New Jersey Department of Environmental Protection

\title{
Simulation of Groundwater Mounding Beneath Hypothetical Stormwater Infiltration Basins
}

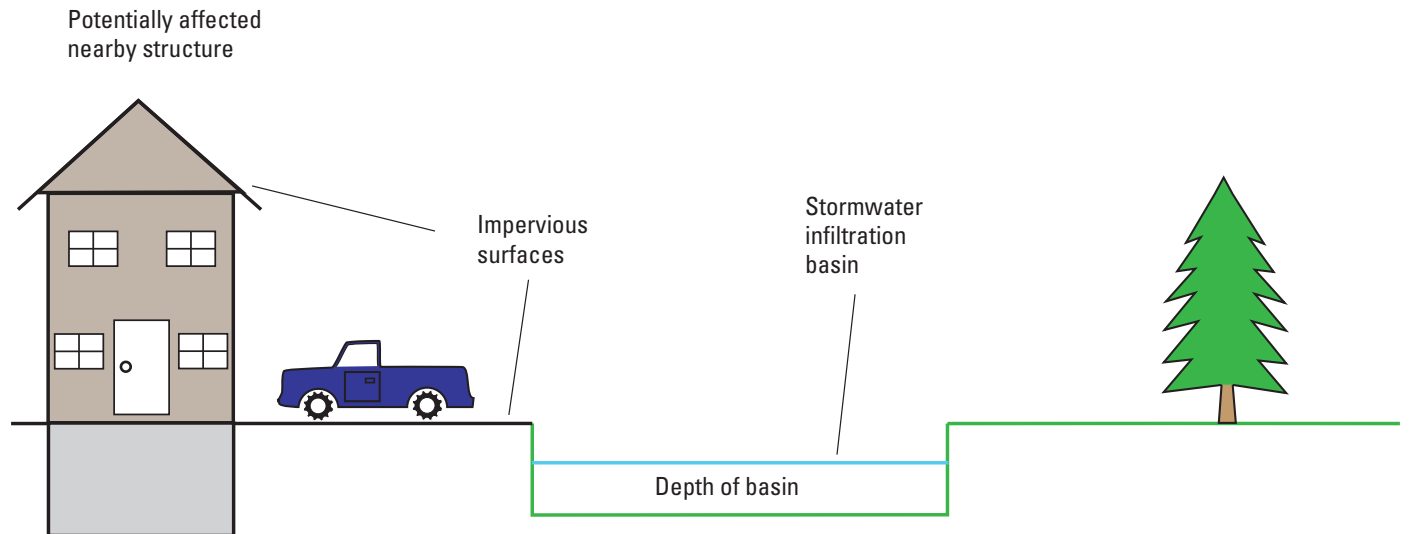

Unsaturated zone

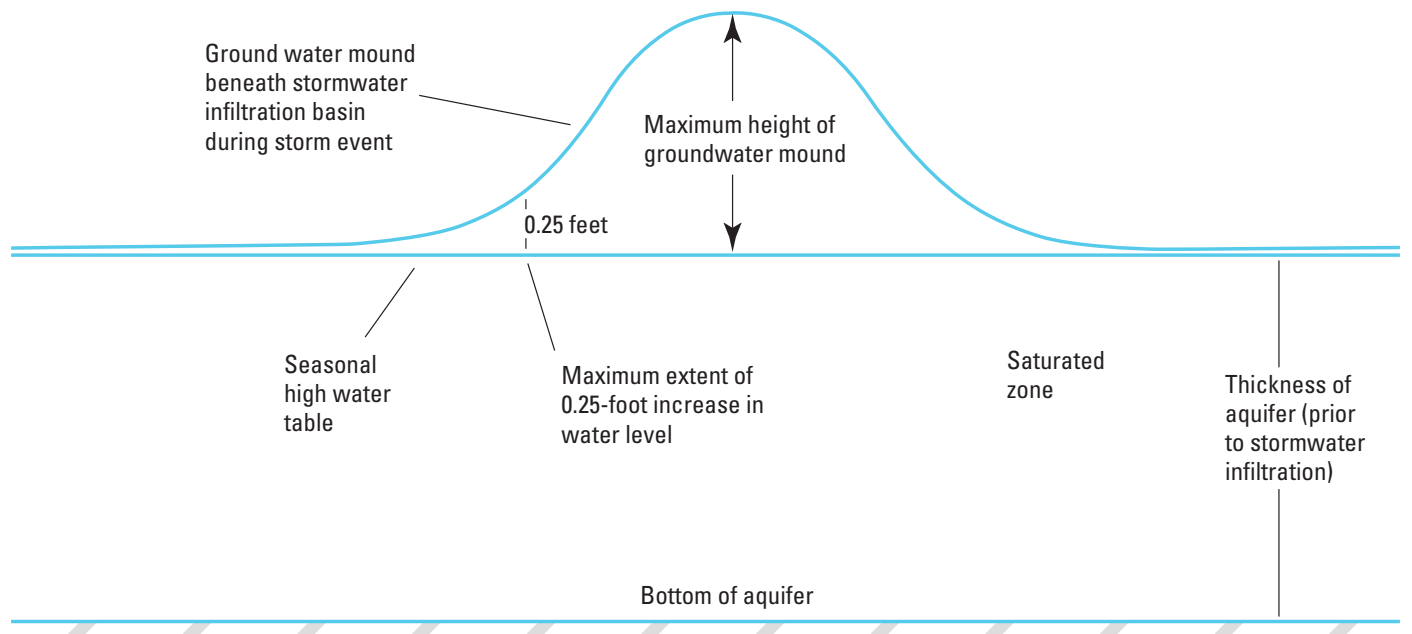

Scientific Investigations Report 2010-5102 



\section{Simulation of Groundwater Mounding Beneath Hypothetical Stormwater Infiltration Basins}

By Glen B. Carleton

Prepared in cooperation with the

New Jersey Department of Environmental Protection

Scientific Investigations Report 2010-5102 


\section{U.S. Department of the Interior \\ KEN SALAZAR, Secretary \\ U.S. Geological Survey \\ Marcia K. McNutt, Director}

\section{U.S. Geological Survey, Reston, Virginia: 2010}

For more information on the USGS - the Federal source for science about the Earth, its natural and living resources, natural hazards, and the environment, visit http://www.usgs.gov or call 1-888-ASK-USGS

For an overview of USGS information products, including maps, imagery, and publications, visit http://www.usgs.gov/pubprod

To order this and other USGS information products, visit http://store.usgs.gov

Any use of trade, product, or firm names is for descriptive purposes only and does not imply endorsement by the U.S. Government. Use of company names is for identification purposes only and does not imply responsibility.

Although this report is in the public domain, permission must be secured from the individual copyright owners to reproduce any copyrighted material contained within this report.

Suggested citation:

Carleton, G.B., 2010, Simulation of groundwater mounding beneath hypothetical stormwater infiltration basins:

U.S. Geological Survey Scientific Investigations Report 2010-5102, 64 p. 


\section{Acknowledgments}

The author thanks Sandra Blick, Supervisor, Stormwater Management Unit, Bureau of Nonpoint Pollution Control, Division of Water Quality, NJDEP, for her vision regarding the need for this research and consistent expertise in directing the work. Kunal Patel, also of the Non-Point Pollution Control Element, provided information on technical details and reviews, including terminology used by soil scientists and groundwater hydrologists. Joseph Skupien, Storm Water Management Consulting, provided extremely valuable insights into basin-design criteria and other subtleties of how developers in New Jersey meet stormwater management regulations. The members of the American Water Resources Association (AWRA) New Jersey Section Stormwater-Best-Management-Practices-Mounding Technical Guidelines Workgroup participated in technical discussions that identified the need for quantitative assessment of variables affecting groundwater mounding. Nicholas Trainor (Rutgers University, Department of Applied Mathematics) used sophisticated mathematical software to solve the Hantush equation and Hunt equation to verify that Excel spreadsheets used in this report accurately solved the analytical equations.

The author is grateful for the assistance of Arthur Baehr (U.S. Geological Survey, retired) in developing the spreadsheet solving the transient Hantush (1967) equation. The author thanks technical reviewers Melinda Chapman (U.S. Geological Survey, North Carolina Water Science Center) and Jeffrey Hoffman (New Jersey Geological Survey). Improvements to illustrations by Gregory Simpson (U.S. Geological Survey) and Jonathan Bucca (Rowan State University) are appreciated. 



\section{Contents}

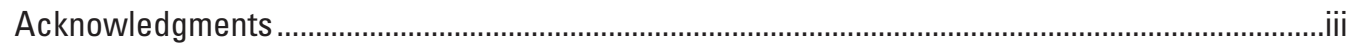

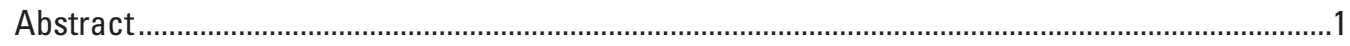

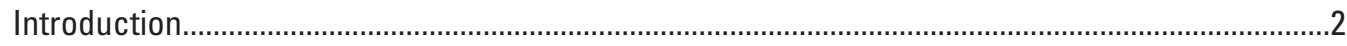

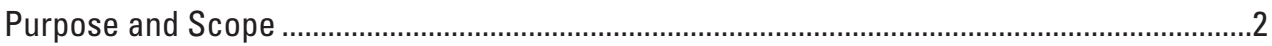

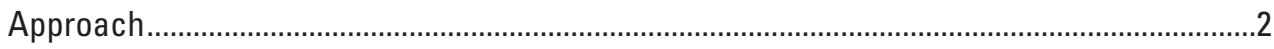

Previous Investigations.........................................................................................................

Physical Variables Affecting Height and Extent of Groundwater Mounding....................................5

Soil Permeability and Aquifer Thickness ............................................................................5

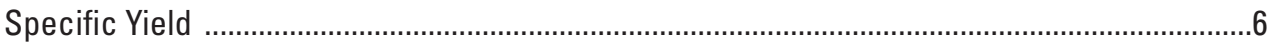

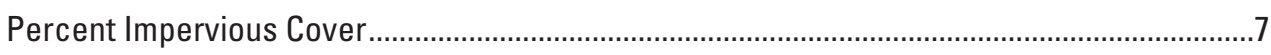

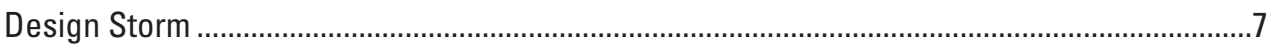

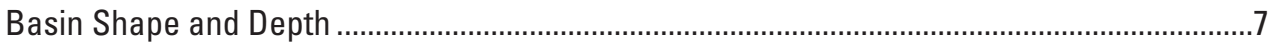

Depth to Water Table ...................................................................................................................

Use of Finite Difference Numerical Models to Estimate Groundwater Mounding ............................8

Model Design...................................................................................................................................... 8

Simulation of Groundwater Mounding Beneath Hypothetical Stormwater Infiltration

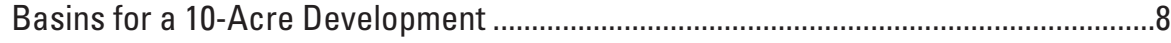

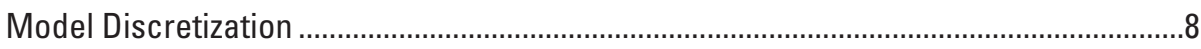

Characteristics Varied to Estimate Groundwater Mounding ............................................10

Model Boundaries, Recharge, and Difference Between Undeveloped and

Developed Water Levels ....................................................................................... 10

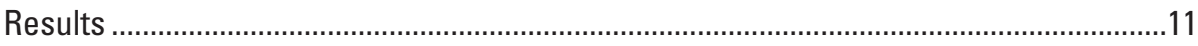

Maximum Height of Groundwater Mounding ......................................................13

Maximum Extent of Groundwater Mounding .........................................................16

Simulation of Groundwater Mounding Beneath Hypothetical Dry Wells for a 1-Acre

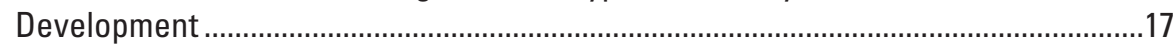

Model Discretization, Boundaries, and Difference Between Undeveloped and Developed Water Levels .................................................................................. 17

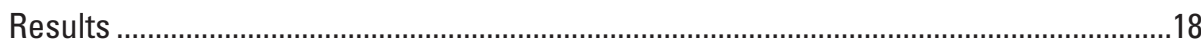

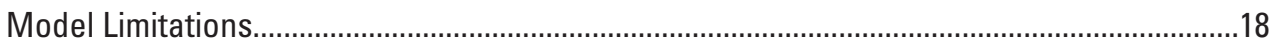

Use of Analytical Equations to Estimate Groundwater Mounding .................................................22

Description of Hantush Equation ...............................................................................................22

Spreadsheet for Solving Hantush Equation ...........................................................................22

Comparison of Analytical and Finite-Difference Estimates of Groundwater Mounding

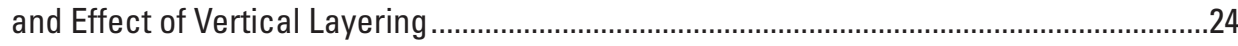

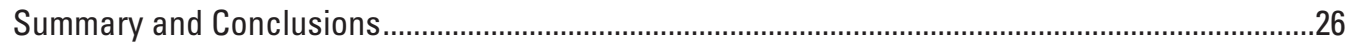

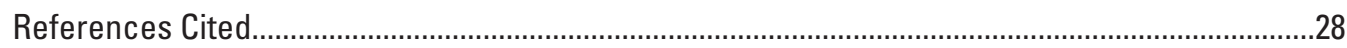




\section{Figures}

1. Schematic representation of a groundwater mound beneath a hypothetical stormwater infiltration basin.

2-3. Maps showing-

2. Model grid and boundary conditions of a finite-difference model used to simulate groundwater mounding beneath hypothetical stormwater infiltration basins on a 10-acre development.

3. Relative size and placement of selected hypothetical infiltration basins used in simulations of groundwater mounding beneath a 10-acre development.

4-5. Box plots showing -

4. Range of maximum height of simulated groundwater mounding beneath hypothetical stormwater infiltration basins on a 10-acre development in relation to aquifer and basin characteristics.

5. Range of maximum extent of 0.25 -foot simulated groundwater mounding beneath hypothetical stormwater infiltration basins on a 10-acre development in relation to aquifer and basin characteristics

6. Schematic diagram showing relative shape of groundwater mounding in aquifers of higher and lower soil permeability.....

7. Model grid and boundary conditions of a finite-difference model used to simulate groundwater mounding beneath hypothetical stormwater infiltration basins on a 1-acre development

8-9. Box plots showing-

8. Range of maximum height of simulated groundwater mounding beneath hypothetical stormwater-infiltration dry wells on a 1-acre development in relation to aquifer and dry well characteristics

9. Range of maximum extent of 0.25 -foot simulated groundwater mounding beneath hypothetical stormwater-infiltration dry wells on a 1-acre development in relation to aquifer and dry well characteristics.

10. User interface page of spreadsheet for solving the Hantush (1967) equation that describes groundwater mounding beneath an infiltration basin with example input and output.

11. Graph showing groundwater mounds beneath hypothetical stormwater-infiltration basins calculated using the Hantush equation and simulated with 1-, 3-, 6-, 9-, and 15-layer finite-difference models

\section{Tables}

1. Values of variables input to the finite-difference simulations of groundwater mounding beneath hypothetical stormwater infiltration basins on 1-acre and 10-acre developments.

2. Simulated groundwater mounding beneath hypothetical stormwater-infiltration basins on a 10 -acre development

3. Simulated groundwater mounding beneath hypothetical stormwater-infiltration dry wells on a 1-acre development

4. Calculated and simulated groundwater mounding beneath hypothetical stormwater-infiltration basins using selected analytical solutions and finite-difference models. 


\section{Conversion Factors}

Inch/Pound to SI

\begin{tabular}{|c|c|c|}
\hline Multiply & By & To obtain \\
\hline \multicolumn{3}{|c|}{ Length } \\
\hline inch (in.) & 2.54 & centimeter $(\mathrm{cm})$ \\
\hline foot $(\mathrm{ft})$ & 0.3048 & meter $(\mathrm{m})$ \\
\hline \multicolumn{3}{|c|}{ Area } \\
\hline acre & 4,047 & square meter $\left(\mathrm{m}^{2}\right)$ \\
\hline acre & 0.4047 & hectare (ha) \\
\hline square foot $\left(\mathrm{ft}^{2}\right)$ & 0.09290 & square meter $\left(\mathrm{m}^{2}\right)$ \\
\hline \multicolumn{3}{|c|}{ Volume } \\
\hline gallon (gal) & 3.785 & liter $(\mathrm{L})$ \\
\hline gallon (gal) & 0.003785 & cubic meter $\left(\mathrm{m}^{3}\right)$ \\
\hline \multicolumn{3}{|c|}{ Flow rate } \\
\hline cubic foot per day $\left(\mathrm{ft}^{3} / \mathrm{d}\right)$ & 0.02832 & cubic meter per day $\left(\mathrm{m}^{3} / \mathrm{d}\right)$ \\
\hline gallon per minute (gal/min) & 0.06309 & liter per second $(\mathrm{L} / \mathrm{s})$ \\
\hline inch per hour (in/h) & 0.0254 & meter per hour $(\mathrm{m} / \mathrm{h})$ \\
\hline inch per year (in/yr) & 25.4 & millimeter per year $(\mathrm{mm} / \mathrm{yr})$ \\
\hline \multicolumn{3}{|c|}{ Hydraulic conductivity } \\
\hline foot per day (ft/d) & 0.3048 & meter per day $(\mathrm{m} / \mathrm{d})$ \\
\hline \multicolumn{3}{|c|}{ Hydraulic gradient } \\
\hline foot per mile (ft/mi) & 0.1894 & meter per kilometer $(\mathrm{m} / \mathrm{km})$ \\
\hline \multicolumn{3}{|c|}{ Transmissivity* } \\
\hline foot squared per day $\left(\mathrm{ft}^{2} / \mathrm{d}\right)$ & 0.09290 & meter squared per day $\left(\mathrm{m}^{2} / \mathrm{d}\right)$ \\
\hline
\end{tabular}

*Transmissivity: The standard unit for transmissivity is cubic foot per day per square foot times foot of aquifer thickness $\left[\left(\mathrm{ft}^{3} / \mathrm{d}\right) / \mathrm{ft}^{2}\right] \mathrm{ft}$. In this report, the mathematically reduced form, foot squared per day $\left(\mathrm{ft}^{2} / \mathrm{d}\right)$, is used for convenience. 



\title{
Simulation of Groundwater Mounding Beneath Hypothetical Stormwater Infiltration Basins
}

\author{
By Glen B. Carleton
}

\section{Abstract}

Groundwater mounding occurs beneath stormwater management structures designed to infiltrate stormwater runoff. Concentrating recharge in a small area can cause groundwater mounding that affects the basements of nearby homes and other structures. Methods for quantitatively predicting the height and extent of groundwater mounding beneath and near stormwater infiltration structures can be used by property developers and regulatory agencies to assess the threat to previously existing or proposed structures.

Finite-difference groundwater-flow simulations of infiltration from hypothetical stormwater infiltration structures (which are typically constructed as basins or dry wells) were done for 10-acre and 1-acre developments. Aquifer and stormwater-runoff characteristics in the model were changed to determine which factors are most likely to have the greatest effect on simulating the maximum height and maximum extent of groundwater mounding. Aquifer characteristics that were changed include soil permeability, aquifer thickness, and specific yield. Stormwater-runoff variables that were changed include magnitude of design storm, percentage of impervious area, infiltration-structure depth (maximum depth of standing water), and infiltration-basin shape. Values used for all variables are representative of typical physical conditions and stormwater management designs in New Jersey but do not include all possible values. Results are considered to be a representative, but not all-inclusive, subset of likely results.

Maximum heights of simulated groundwater mounds beneath stormwater infiltration structures are the most sensitive to (show the greatest change with changes to) soil permeability. The maximum height of the groundwater mound is higher when values of soil permeability, aquifer thickness, or specific yield are decreased or when basin depth is increased or the basin shape is square (and values of other variables are held constant). Changing soil permeability, aquifer thickness, specific yield, infiltration-structure depth, or infiltration-structure shape does not change the volume of water infiltrated, it changes the shape or height of the groundwater mound resulting from the infiltration. An aquifer with a greater soil permeability or aquifer thickness has an increased ability to transmit water away from the source of infiltration than aquifers with lower soil permeability; therefore, the maximum height of the groundwater mound will be lower, and the areal extent of mounding will be larger.

The maximum height of groundwater mounding is higher when values of design storm magnitude or percentage of impervious cover (from which runoff is captured) are increased (and other variables are held constant) because the total volume of water to be infiltrated is larger. The larger the volume of infiltrated water the higher the head required to move that water away from the source of recharge if the physical characteristics of the aquifer are unchanged. The areal extent of groundwater mounding increases when soil permeability, aquifer thickness, design-storm magnitude, or percentage of impervious cover are increased (and values of other variables are held constant).

For 10-acre sites, the maximum heights of the simulated groundwater mound range from 0.1 to 18.5 feet $(\mathrm{ft})$. The median of the maximum-height distribution from 576 simulations is $1.8 \mathrm{ft}$. The maximum areal extent (measured from the edge of the infiltration basins) of groundwater mounding of 0.25 -ft ranges from 0 to $300 \mathrm{ft}$ with a median of $51 \mathrm{ft}$ for 576 simulations. Stormwater infiltration at a 1-acre development was simulated, incorporating the assumption that the hypothetical infiltration structure would be a pre-cast concrete dry well having side openings and an open bottom. The maximum heights of the simulated groundwater-mounds range from 0.01 to $14.0 \mathrm{ft}$. The median of the maximum-height distribution from 432 simulations is $1.0 \mathrm{ft}$. The maximum areal extent of groundwater mounding of $0.25-\mathrm{ft}$ ranges from 0 to $100 \mathrm{ft}$ with a median of $10 \mathrm{ft}$ for 432 simulations.

Simulated height and extent of groundwater mounding associated with a hypothetical stormwater infiltration basin for 10 -acre and 1-acre developments may be applicable to sites of different sizes. For example, for a 20 -acre site with 20 percent impervious surface, the stormwater infiltration basin design capacity (and associated groundwater mound) would be the same as for a 10-acre site with 40 percent impervious surface.

A spreadsheet was developed to solve the Hantush analytical equation, which can be used to calculate groundwater mounding. The Hantush equation incorporates simplifying assumptions, including that all flow is horizontal. The spreadsheet accepts user-supplied values for horizontal soil permeability, initial saturated aquifer thickness, specific yield, basin 
length, basin width, and duration and magnitude of recharge rate. Comparison of results of finite-difference simulations of a multi-layer system that includes a vertical component of flow in the saturated zone with the results from the analytical equation indicates that the horizontal-flow-only assumption in the analytical equation can cause an under-prediction of the maximum height of a groundwater mound by as much as 15 percent. The more realistic representation of the vertical component of flow and the ability to include site-specific details make finite-difference models such as MODFLOW potentially more accurate than analytical equations for predicting groundwater mounding.

\section{Introduction}

In 2004, the New Jersey Department of Environmental Protection (NJDEP) implemented stormwater-management rules that include the requirement that "substantial" (greater than 1 acre) new development must have no net loss in groundwater recharge (New Jersey Administrative Code 7:8-5.4(a)2, 2004). Therefore, the amount of recharge that is rejected by new impervious surfaces, such as roofs or driveways, must be infiltrated elsewhere, often through engineered structures such as stormwater infiltration basins or dry wells (fig. 1). An unintended consequence of this rule is that nearby structures, such as basements, can experience flooding caused by the localized mounding of the water table associated with concentrated recharge, particularly during intense (largevolume) recharge events. In 2007, the U.S. Geological Survey (USGS), in cooperation with the New Jersey Department of Environmental Protection, initiated a study to evaluate which physical characteristics associated with stormwater infiltration basins and the underlying aquifer have the greatest effect on groundwater mounding.

Stormwater infiltration basins designed with inaccurate assumptions or insufficient analysis may not function as designed. For example, calculations to estimate the amount of time required for the basin to drain typically are based on the assumption of vertical flow out of the basin bottom into unsaturated sediments. If groundwater mounding of the underlying water table reaches the bottom of the infiltration basin, the rate of infiltration out of the basin will decrease substantially.

Several analytical equations have been developed to predict the height of the water table beneath an infiltration basin. The use of these equations by designers of stormwater infiltration basins has been limited by the paucity of available tools for solving them. Numerical groundwater-flow models can be used but considerable training is required to develop, run, and interpret results from numerical models. Designers could benefit from a consistent method to quickly quantify the predicted height of a groundwater mound beneath and near a proposed infiltration basin. Such a quantitative method could also allow regulators to objectively evaluate applications and determine whether groundwater mounding associated with a proposed infiltration basin would be likely to prevent the basin from functioning properly or pose a potential threat to nearby structures.

The goal of this study was to provide quantitative methods for estimating the height of groundwater mounds beneath infiltration basins that can be used by (1) engineers preparing stormwater infiltration basin designs and (2) regulators reviewing those designs. These methods can be used to predict the magnitude and extent of groundwater mounding beneath and adjacent to engineered stormwater infiltration structures during recharge events under specific conditions. A number of variables (including hydrogeologic characteristics and infiltration structure design) were evaluated to better understand which factors most affect the magnitude and extent of groundwater mounding.

\section{Purpose and Scope}

Analytical and numerical techniques used to estimate the magnitude and extent of groundwater mounding beneath infiltration structures are presented in this report. Analytical equations are evaluated, and use of a spreadsheet developed to solve the Hantush (1967) equation (for the growth of groundwater mounds in response to uniform infiltration beneath an infiltration structure) with user input for aquifer and infiltration-structure characteristics is described. Numerical groundwater-flow models constructed for both 1-acre and 10-acre hypothetical developments also are described along with results of hundreds of simulations of combinations of variables including soil permeability, aquifer thickness, aquifer specific yield, design storm magnitude, basin depth, basin shape, and percentage of impervious surface. Box plots show the simulated maximum height of groundwater mounds and maximum extent of groundwater mounding of $0.25-\mathrm{ft}$ and illustrate which variables have the greatest effect on groundwater-mound height and extent. A table is presented that lists for each of the 10-acre and 1-acre developments the simulated maximum height of groundwater mounding, maximum radius of 0.25 -ft height, and groundwater mounding at several fixed distances from the edge of the basin for each of the hundreds of variable combinations.

\section{Approach}

Two methods were used to quantitatively estimate the height and extent of groundwater mounds near proposed stormwater infiltration basins - (1) a spreadsheet to numerically integrate equations presented by Hantush (1967) and (2) three-dimensional finite-difference groundwater-flow models. Hantush's equations define the shape of groundwater mounds beneath rectangular (including square) or round infiltration basins, and are based on several simplifying assumptions, including that the aquifer is homogeneous and isotropic, flow 


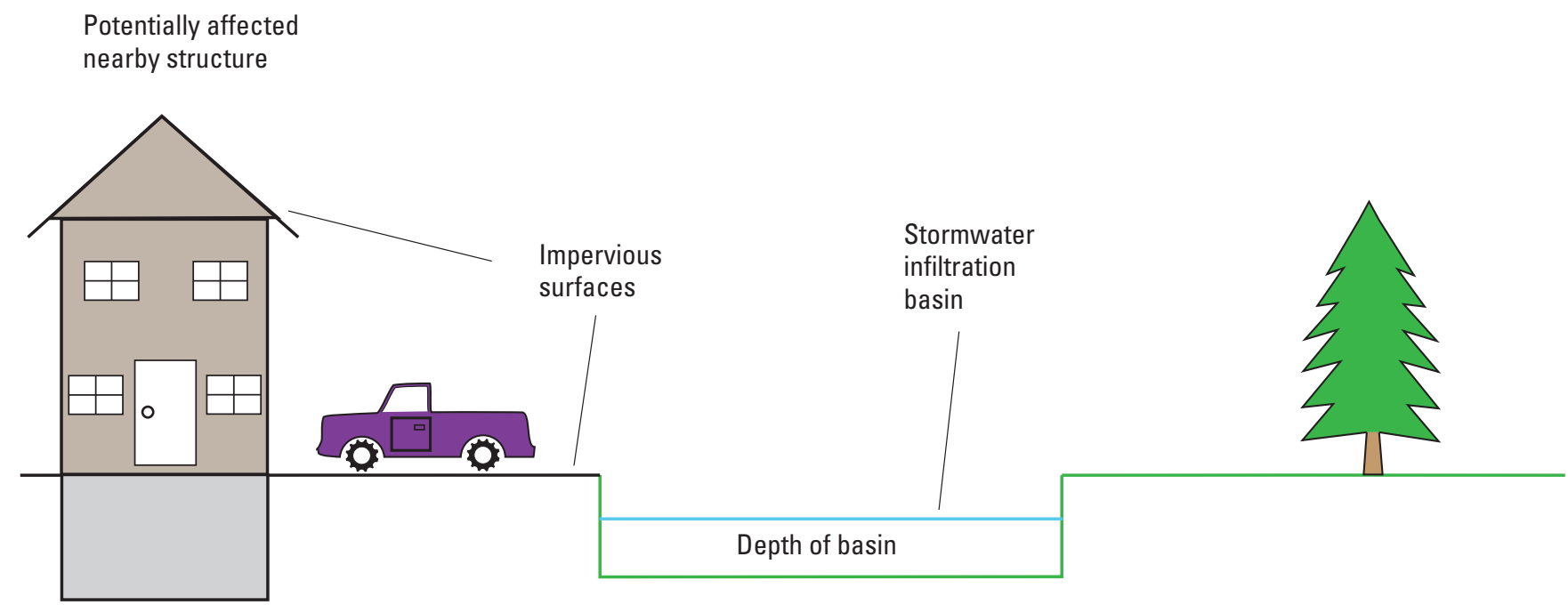

Unsaturated zone
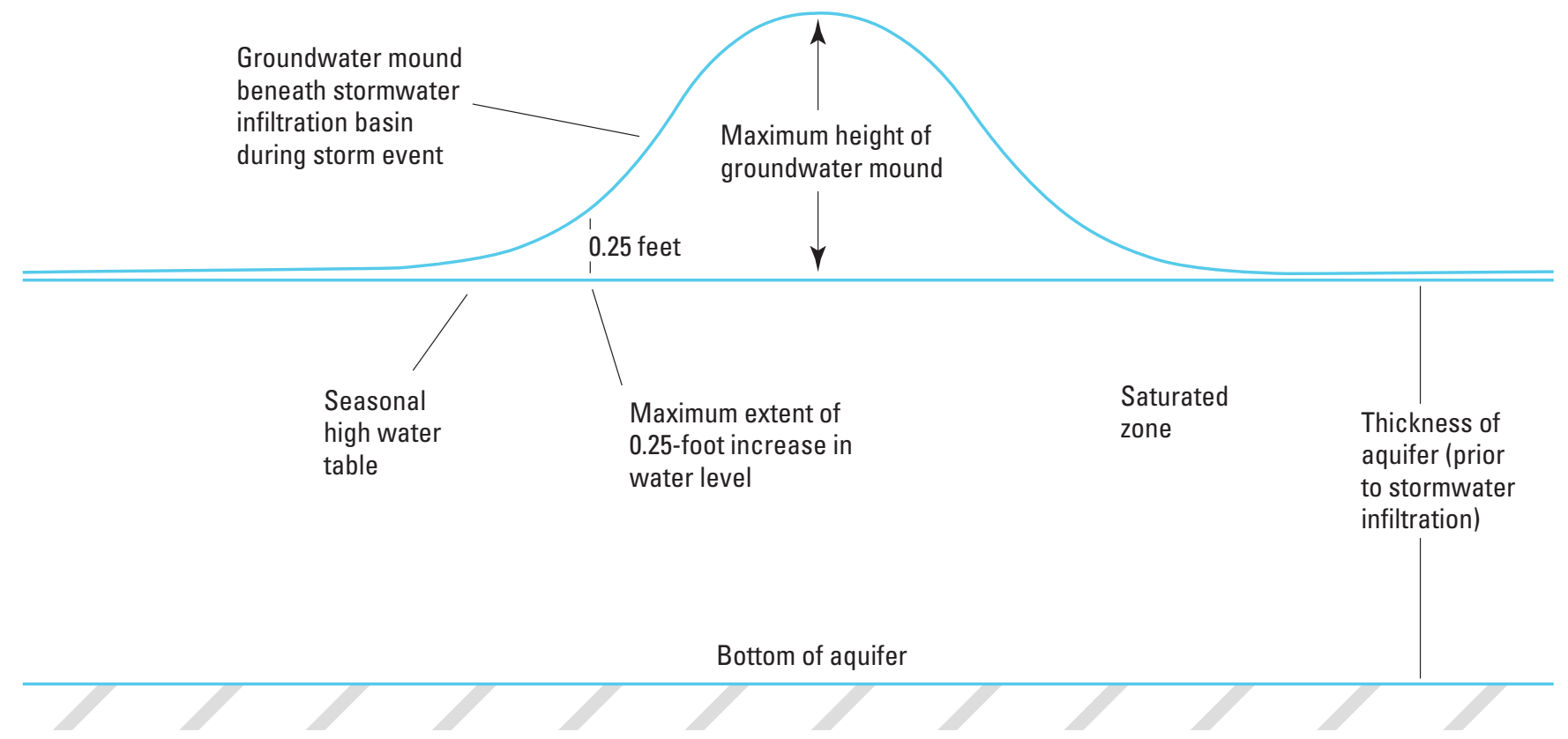

Figure 1. Schematic representation of a groundwater mound beneath a hypothetical stormwater infiltration basin.

is strictly horizontal, the change in aquifer saturated thickness relative to original saturated thickness is trivial, and the infiltration rate is constant.

The finite-difference groundwater-flow model MODFLOW-2000 (Harbaugh and others, 2000) was used to simulate the height and extent of groundwater mounds beneath infiltration basins with various aquifer characteristics, recharge conditions, and basin areas, depths, and shapes. Hundreds of simulations were completed in which two to four values for each of seven variables were altered to estimate groundwater mounds in various hypothetical settings and design constraints. The seven variables that were altered are soil permeability, aquifer thickness, specific yield, infiltration basin depth, basin shape, magnitude of design storm, and percentage of impervious land cover. The seven variables and appropriate values for New Jersey were determined in coordination with Sandra Blick (NJDEP), Joseph Skupien (Storm Water Management Consulting, LLC), and members of the NJDEP Stormwater Best Management Practices (BMP) Committee.

Values of variables used in the simulations were chosen to include a realistic range of values and to keep the number of simulations small enough to be readily interpreted. The values 
selected (and the rationale for selecting those values) are discussed farther on in the "Physical Variables Affecting Height and Extent of Groundwater Mounding" section of this report. Tables are provided in the "Results" sections that list the maximum height, maximum extent, and height at fixed distances of a groundwater mound beneath infiltration basins designed to infiltrate runoff from a 10 -acre or 1-acre development.

For the 10 -acre system, transient simulations with constant recharge for 1.5 days ( 36 hours) were made for predevelopment and post-development conditions. Recharge for pre-developed conditions was uniform throughout the model area, with no impervious surface and no infiltration basin. Recharge for developed conditions was the same as predevelopment recharge outside the 10-acre developed area. The developed area received less recharge because of impervious surfaces, and the infiltration basin received the recharge rejected by the impervious surfaces in the developed area. Precipitation was assumed to reach the water table without loss to evapotranspiration or surface runoff to surface-water bodies. Initial conditions included no antecedent recharge and a flat water table. The height and extent of the groundwater mound was calculated by subtracting water levels simulated under predevelopment conditions from water levels simulated under post-development conditions.

For the 1-acre system, the effect of reduced recharge from impervious surfaces over such a small area was not considered to be important; therefore, predevelopment conditions were not simulated. Simulations included only recharge to the infiltration basin (dry well), and groundwater mounding was calculated directly as the increase in water level associated with recharge introduced at the infiltration basin.

The lateral and bottom boundaries of the model are noflow boundaries. The lateral boundaries were set sufficiently far from the infiltration basins, such that simulated water-level increases at all boundaries was less than $0.01 \mathrm{ft}$ for all simulations. A surface-water drain simulated using the MODFLOW Drain Package was included in the simulations of a 10-acre development to test whether presence or absence of a stream at that distance affected results. The surface-water boundary had no effect on the simulated groundwater mound because the change in flow to the drain was less than 0.1 percent under pre- and post-development recharge.

The infiltration basin for each simulation had a volume (basin depth multiplied by area) equal to the recharge rejected by the impervious surfaces (stormwater-runoff design-storm depth multiplied by area of impervious surface). To minimize the number of basin footprints needed for the simulations, variables that determine the required area of the basin were varied by a factor of two or four. For example, two design storm magnitudes were considered, with the first selected to be the NJDEP stormwater quality design storm of 1.25 inches, so the second storm was chosen to be 0.3125 inch (one-fourth of 1.25 inches, rounded to 0.31 inch in the remainder of this report). Similarly, infiltration basins are often designed to be $2 \mathrm{ft}$ deep (greater depths could pose a drowning hazard), but shallower depths are sometimes used, so a depth of $0.5 \mathrm{ft}$ (one-fourth of $2 \mathrm{ft}$ ) was chosen. Therefore, for a given percentage of impervious area, the basin footprint required for a design storm magnitude of $1.25 \mathrm{in}$. and a basin depth of $2 \mathrm{ft}$ is the same as for a design storm magnitude of $0.31 \mathrm{in}$. and a basin depth of $0.5 \mathrm{ft}$. For this study the design-storm magnitude is assumed to have fully infiltrated pervious surfaces under predevelopment conditions; the runoff from the design storms that must be infiltrated is assumed to be the magnitude of the design storm with no allowance for evaporation from impervious surfaces or runoff from natural, pervious surfaces.

The simulations do not include any delay or attenuation associated with travel through the unsaturated zone. Also, the volume of water from the design storm falling on impervious surface is simulated as directly recharging the water table at the infiltration basin over 36 hours.

For analytical methods such as that proposed by Hantush (1967), horizontal flow is assumed; therefore, vertical anisotropy of hydraulic conductivity (vertical hydraulic conductivity, also called soil permeability, is different from, usually less than, horizontal hydraulic conductivity) is not accounted for in the method. Use of multiple layers in MODFLOW allows inclusion of vertical anisotropy. The number of layers used to represent the aquifer was chosen to be three to balance the need for multiple layers with the need for keeping the runtimes of simulations to a minimum. The difference in results from simulations with fewer or greater than three layers is discussed in the "Comparison of Analytical and Finite-Difference Estimates of Groundwater Mounding and Effect of Vertical Layering" section of this report.

In the 576 simulations for the 10 -acre site, 7 of the MODFLOW input files were identical: the Basic, Drain, and Pre-conditioned Conjugate Gradient (solver) Packages, Output Control Option, Observation Process, and Name and Observation Data files. These files were copied into 576 sequentially numbered directories. The MODFLOW input files that varied among simulations - the Discretization Package (includes aquifer thickness), Layer Property Flow Package (includes soil permeability and specific yield), and Recharge Package files -were copied into the appropriate directories. The goal for the simulations for the 10 -acre site was to simulate aquifer response to a recharge event where recharge was reduced in the developed area and concentrated at an infiltration basin. Because the aquifer response is, in part, a function of aquifer characteristics, aquifer response to recharge under predevelopment (uniform) conditions was simulated for each unique combination of aquifer characteristics and design storm magnitude. Binary files of aquifer heads from the predevelopment simulations were copied into the appropriate directories. After the post-development simulations were completed, a FORTRAN program was used to extract the water levels from the binary head file for each simulation, subtract the predevelopment water level from the post-development water level; calculate the maximum change in head, calculate the maximum extent of groundwater mounding of $0.25-\mathrm{ft}$ and the change in water levels at fixed distances from the right edge of the infiltration basin, and save the results to a summary file. 
In the 432 simulations for the 1 -acre site, the same procedure was followed, except recharge over the 1-acre area was not reduced by the percentage of impervious cover. Therefore, the water-level change was calculated by the MODFLOW Drawdown Output Control option without the need for subtracting predevelopment from post-development water levels.

\section{Previous Investigations}

Artificial recharge of groundwater through recharge basins has been conducted for various reasons. In some applications the goal is to store excess water available seasonally (for example, during periods of snow melt) for later use in irrigation. In other applications the goal is to dispose of treated wastewater. Infiltration of stormwater runoff is a similar application, although the timeframe of infiltration is shorter than for the preceding examples.

Recharge basins and the effects on the underlying water table have been widely studied for decades. A number of investigators have presented analytical solutions for the shape of the water table beneath an artificial recharge basin, including Baumann (1952), Glover (1960), Hantush (1967), Rao and Sarma (1981), and Hunt (1971). Sunada and others (1983) and Warner and others (1989) evaluated the above solutions. Rai and Singh (1981) presented a similar analytical solution to that of Hantush (1967), and in a number of subsequent articles they (sometimes with other authors) present solutions that include a variety of different boundary conditions (for example, Manglik and others, 1997, 2003). Marino (1974) and Latinopoulos $(1981,1984)$ also present several analytical solutions to the problem with different boundary conditions. For all of the analytical solutions referenced above, it is assumed that flow away from the location of the recharge basin is horizontal and occurs in an isotropic, homogeneous aquifer in which the change in height of the water table is not large (generally less than one-half the aquifer thickness).

Although the above analytical solutions have been used to simulate the shape of a groundwater mound beneath hypothetical infiltration basins, they are difficult to apply without numerical integration. Sunada and others (1983) found the solution of Hantush (1967) to be the most accurate and amenable to numerical integration. Sunada and others (1983) and Warner and others (1989) developed computer programs to solve the Hantush equation for steady (continuous) or transient recharge with user-specified input variables of transmissivity, basin size, and recharge rate. These computer programs are no longer readily available and do not run on some personal computers (for example, they will not run on computers using a 64-bit processor). Finnemore (1995) presents a computer program for solving the Hantush (1967) equation, and Zomorodi (2005) offers a simplified method for solving the Hantush equation, but both approaches are used only with steady-state conditions. Poeter and others (2005) also evaluate groundwater mounding under steady-state conditions. Engineering Software, Inc. (2006), developed proprietary software,
MODRET, that is based on the USGS finite-difference model MODFLOW. The software, initially developed for use in engineered aquifer-recharge facilities in Florida, calculates unsaturated and saturated losses and groundwater mounding from infiltration basins; it includes limited surface-water flow routing. MODRET is designed as a 1-layer aquifer and, therefore, does not include the effects of vertical anisotropy (aquifer permeability in the vertical direction differs from that in the horizontal direction).

Sumner and Bradner (1996) and Sumner and others (1999) simulated infiltration from artificial recharge basins with the USGS variably saturated, two-dimensional flow model (VS2D). They found that analyses that ignore the unsaturated zone (as do all of the analytical and finite-difference methods referenced above) may over-estimate the height of the groundwater mound occurring beneath an infiltration basin and may not correctly estimate the behavior over time because of storage and delay in the unsaturated zone.

\section{Physical Variables Affecting Height and Extent of Groundwater Mounding}

New Jersey regulations (New Jersey Administrative Code 7:8-5.4(a)2, 2004) require the recharge of stormwater falling on newly added impervious surfaces. The physical characteristics of the aquifer, stormwater infiltration basin, and design storm can all contribute to the height and breadth of a groundwater mound occurring under a stormwater infiltration structure. The physical characteristics that were varied in the simulations are discussed below.

\section{Soil Permeability and Aquifer Thickness}

The ability of an aquifer to transmit water from an area of higher water level (head) to lower water level is quantified as the aquifer transmissivity. Transmissivity is the horizontal hydraulic conductivity multiplied by aquifer thickness (typically written $\mathrm{T}=\mathrm{Kb}$, where $\mathrm{K}$ is in units of length per time ( $\mathrm{L} / \mathrm{T})$ and $\mathrm{b}$ is in units of length). The thickness of the water-table aquifer in most locations in New Jersey ranges from about 10 to $200 \mathrm{ft}$ (about one order of magnitude) (see, for example, Nicholson and others, 1996; Johnson and Watt, 1996; Johnson and Charles, 1997; and Charles and others, 2001). In northern New Jersey bedrock is commonly close to land surface and the unconsolidated sediments can be $10 \mathrm{ft}$ or less in thickness. Areas covered by glacial till can be tens of feet thick, and glacially buried valleys commonly have as much as $100 \mathrm{ft}$ of unconsolidated sediments comprising the water-table aquifer. Where the water-table aquifer occurs in bedrock, typically most water-producing fractures are present in the upper $200 \mathrm{ft}$ and most of the groundwater flow occurs in this portion of the aquifer (for example, see Carleton and others, 1999). Coastal Plain aquifers typically are less than $100 \mathrm{ft}$ 
Simulation of Groundwater Mounding Beneath Hypothetical Stormwater Infiltration Basins

thick where they crop out, with the notable exception of the Kirkwood-Cohansey aquifer, although in most locations a clay layer is encountered within the top $200 \mathrm{ft}$ of the KirkwoodCohansey aquifer (Zapecza, 1989).

The horizontal hydraulic conductivity of the unconfined aquifers in New Jersey ranges over several orders of magnitude, about 0.01 to 200 feet per day (ft/d) (Nicholson and others, 1996; Johnson and Watt, 1996; Johnson and Charles, 1997; Charles and others, 2001; and Carleton and others, 1999). When simulating groundwater mounding associated with stormwater infiltration, the large variations in horizontal hydraulic conductivity make it the more important and controlling variable compared to aquifer thickness. Because thickness is readily measured (using surface geophysics for example), it was also varied in the analyses.

In soil science, the term soil permeability has the same units and meaning as hydraulic conductivity, usually measured in the vertical direction (see, for example, Ritter, 2006), and is a measure of the resistance to flow of water through a unit volume of material. In groundwater hydrology and petroleum engineering, intrinsic permeability is a property of the porous medium independent of the material and is in units of length squared (Fetter, 1994, p. 96). Hydraulic conductivity is a function of the intrinsic permeability and the specific weight and dynamic viscosity of the fluid flowing through the material. In most soil science applications the fluid of interest is water that has a density and viscosity that can be assumed to be constant; therefore, the term soil permeability (in this report and many other publications) is used interchangeably with vertical hydraulic conductivity.

Measurements of soil permeability in the unsaturated zone are measurements of vertical hydraulic conductivity and are referred to as an infiltration rate, often reported in inches per hour. The permeability of unsaturated sediments varies with the degree of saturation. Quantifying the effects of variably saturated permeabilities in the unsaturated zone is beyond the scope of this report. In the saturated zone (aquifers and confining units), horizontal hydraulic conductivity is often measured by conducting an aquifer test; the resulting estimates are often reported in feet per day.

Horizontal hydraulic conductivity in unconsolidated sediments is usually greater than vertical hydraulic conductivity (soil permeability). Often only vertical or only horizontal conductivity is measured, and the directional hydraulic conductivity that was not measured is calculated by assuming a 10:1 ratio of horizontal to vertical hydraulic conductivity (Anderson and Woessner, 1991; Pope and Watt, 2005; Modica, 1996; Cauller and Carleton, 2006). This vertical anisotropy can be caused by generally flat-lying mineral grain orientation and (or) layers of finer sediments interspersed with coarser, more permeable sediments. Vertical anisotropy is scale dependent. Freeze and Cherry (1979, p. 32-34) state that vertical anisotropy in cores rarely exceeds 10:1 and is usually less than $3: 1$, but it is not uncommon for regional anisotropy to be 100:1 or greater. On a county-wide scale, Kauffman and others (2001) used horizontal to vertical hydraulic conductivity ratios from 1:1 to $178: 1$ to calibrate a groundwater-flow model in an unconfined aquifer in the Coastal Plain of New Jersey. The ratio of horizontal to vertical hydraulic conductivity of 10:1 was used in all simulations in this study.

The ratio of horizontal to vertical hydraulic conductivity can be estimated by analyzing multiple-well aquifer tests or making separate measurements of vertical hydraulic conductivity (for example, with a soil permeameter) and horizontal hydraulic conductivity (for example, a slug test or aquifer test). Where no estimate of the ratio is available, using a measured or estimated vertical hydraulic conductivity (soil permeability) for both vertical and horizontal hydraulic conductivity (ratio of 1:1) is a conservative assumption.

The soil permeabilities used in this study to represent typical conditions were $0.2 \mathrm{in} / \mathrm{hr}, 1 \mathrm{in} / \mathrm{hr}$, and $5 \mathrm{in} / \mathrm{hr}$. The lowest value, $0.2 \mathrm{in} / \mathrm{hr}$ was chosen because that is the minimum soil permeability allowed for basins that infiltrate the groundwater recharge design storm (Sandra Blick, New Jersey Department of Environmental Protection, oral commun., 2008). The National Resources Conservation Service (2009) has four soil hydrology categories: permeability less than $0.02 \mathrm{in} / \mathrm{hr}$, $0.06 \mathrm{in} / \mathrm{hr}$ to less than $0.57 \mathrm{in} / \mathrm{hr}, 0.57 \mathrm{in} / \mathrm{hr}$ to $1.42 \mathrm{in} / \mathrm{hr}$, and greater than $1.42 \mathrm{in} / \mathrm{hr}$. Soil permeability of $1 \mathrm{in} / \mathrm{hr}$ was chosen as the middle value for this study because it is the approximate midpoint of the third soil permeability category and is five times the minimum value used. Soil permeability of $5 \mathrm{in} / \mathrm{hr}$ was chosen as the third value for this study because it is five times the second value and represents a reasonable midpoint between $1 \mathrm{in} / \mathrm{hr}$ and $20 \mathrm{in} / \mathrm{hr}$ (the highest value in the database); 38 percent of average permeabilities in the National Resources Conservation Service (2009) database are between $1 \mathrm{in} / \mathrm{hr}$ and $5 \mathrm{in} / \mathrm{hr}$, and 19 percent are greater than $5 \mathrm{in} / \mathrm{hr}$. The higher two soil permeabilities used for this study, $1 \mathrm{in} / \mathrm{hr}$ and $5 \mathrm{in} / \mathrm{hr}$, are equivalent to horizontal hydraulic conductivities of $20 \mathrm{ft} / \mathrm{d}$ and $100 \mathrm{ft} / \mathrm{d}$, respectively (assuming a 1:10 vertical anisotropy ratio), values that are representative for New Jersey. Reported horizontal hydraulic conductivities in unconsolidated water-table aquifers in New Jersey (including glacial till, glacial outwash, and Coastal Plain sediments) range from 7 to $800 \mathrm{ft} / \mathrm{d}$ with average values ranging from 87 to $160 \mathrm{ft} / \mathrm{d}$ reported by different authors (New Jersey Geological Survey, 2008; Nicholson and others, 1996; Johnson and Watt, 1996; Johnson and Charles, 1997; and Charles and others, 2001).

\section{Specific Yield}

Specific yield governs how much water the unsaturated zone can store when recharge reaches the water table. Specific yield is related to porosity. The total porosity is defined as the volume of the void space divided by the total volume, often expressed as a percentage. Typical unconsolidated sediment porosities range from about 20 to 40 percent (Fetter, 1994, p. 86). However, not all of the void space is available for stormwater storage because water adheres to grains of sediment (specific retention) and reduces the amount of storage for subsequent recharge. 
Total porosity is equal to specific yield (Sy) plus specific retention ( $\mathrm{Sr}$ ). Specific yield is the volume of water that will drain from the sediment, as a result of gravity, divided by the total volume. Specific retention is the volume of water remaining divided by the total volume. Specific yield and specific retention are often expressed as percentages. Coarse sediments will have a lower specific retention and higher specific yield than fine-grained sediments that have the same porosity. Field capacity is the term used in soil science for the concept of specific retention but includes a time component-for example, the percentage that will drain in 24 hours. This term is used in agriculture because it represents the amount of water potentially available for plants to take up. There is no corresponding term in soil science for specific yield, representing the volume of water drained. Specific yield was estimated to be 17 percent for the water-table aquifer in Cape May County, New Jersey (Gill, 1962), and that value was used for this study. A value of one-half of 17 percent, 8.5 percent, also was used for this study, allowing evaluation of the sensitivity of results to specific yield.

\section{Percent Impervious Cover}

New Jersey stormwater management regulations (New Jersey Administrative Code 7:8-5.4(a)2, 2004) require that a new development that adds impervious cover (pavement, rooftops) includes stormwater management. The larger the percentage of impervious cover, the larger the volume of water that must be infiltrated by the recharge basin. A larger volume of infiltrated water will result in a higher groundwater mound and an increased radius of groundwater mounding in the underlying aquifer because a steeper groundwater gradient is required to push the larger volume away from the area where infiltration occurs. Four different impervious cover percentages were used in simulations for this study: $10,20,40$, and 80 .

\section{Design Storm}

Infiltration basins are designed to accept runoff from storms of different magnitudes according to design constraints of individual sites. For example, if an area is determined to typically have $16 \mathrm{in} / \mathrm{yr}$ of groundwater recharge and the development is expected to result in 10 percent impervious cover, then the infiltration basin must be able to infiltrate each year a volume of water equivalent to 1.6 inches of precipitation across the site. A designer would need to determine the depth of precipitation that must be captured from each precipitation event in an average year to yield 1.6 inches of annual recharge. However, for a development that wishes to capture only runoff from rooftops, not roads, the depth of precipitation from each storm that is required to be captured in the infiltration basin would be greater than if the runoff from all impervious surfaces were being channeled to the basin (Joseph Skupien, Storm Water Management Consulting, LLC, oral commun.,
2008). Data for New Jersey have been compiled to show, on average, how many storms per year are less than or equal to a given precipitation depth (Leon Kauffman, U.S. Geological Survey, written commun., 2001).

A 1.25-inch storm was chosen as one of the design storms for this project because that value is the NJDEP water-quality design storm magnitude (Sandra Blick, New Jersey Department of Environmental Protection, written commun., 2008). NJDEP regulations define the water-quality design storm magnitude as 1.25 inches in 2 hours (New Jersey Administrative Code 7:8-5.4(a)2, 2004), but for this study the simulation period is 36 hours because the infiltration basins are assumed to have the capacity to accept and store all of the runoff from the storm, regardless of the duration. A second design storm of 0.3125 inch (rounded to 0.31 inch) was chosen because it is one-fourth of the 1.25-inch storm, reducing the number of basin footprints used in the simulations: a simulation with 10 -percent impervious cover and a 1.25-inch storm requires the same infiltration basin size as one with 40-percent impervious cover and a 0.31 -inch storm. For comparison purposes, 65 percent of average annual precipitation is derived from storms of 1.25 inches or less, and 14 percent of average annual precipitation is derived from storms of 0.31 inch or less (Leon Kauffman, U.S. Geological Survey, written commun., 2001).

For this study the design-storm magnitude is assumed to have fully infiltrated pervious surfaces under predevelopment conditions with no runoff. Therefore, for the percentage of the hypothetical development that will be converted to impervious surface, the runoff from the design storms that must be infiltrated is assumed to be the magnitude of the design storm. There is no allowance for evaporation from impervious surfaces or runoff from natural, pervious surfaces.

\section{Basin Shape and Depth}

To minimize construction costs and land area required, stormwater infiltration basins are usually designed to be the smallest footprint that will capture and store the volume of runoff indicated by regulations and site conditions. A basin designed to capture runoff from a 20 -acre development with 10 percent impervious cover would be the same size as that for a 5 -acre development with 40 percent impervious cover (other factors being equal). Basin shapes can vary from round to square to elongate. The height and radius of a groundwater mound beneath a square basin will be virtually the same as that beneath a round basin, but a square basin can be better represented than a round basin with a finite-difference model. The rate at which water will drain down through the bottom of the basin can be greatly reduced (compared to the natural undisturbed materials) if equipment is driven on the basin during construction. The basin area required for a development can be large enough that available construction equipment does not have sufficient horizontal reach to excavate a round or square basin of sufficient size from the edges. In this case a rectangular basin may be constructed where the width 
is determined by the reach of the construction equipment, and the necessary length is calculated by dividing the required volume by the achievable width. For this study, simulated basins were square or rectangular (width to length ratio of 1 to 8 ).

For safety reasons, stormwater infiltration basins are often designed to have no more than $2 \mathrm{ft}$ of standing water. In some circumstances, depths of less than $2 \mathrm{ft}$ are used in basin design (Sandra Blick, New Jersey Department of Environmental Protection, oral commun., 2008), so for this study 2 -ft and 0.5 -ft depths were modeled.

Single-home stormwater-management structures sometimes include a dry well (seepage pit) to temporarily store runoff. A dry well can simply be an excavation filled with crushed rock or can be made with a pre-cast concrete structure. Pre-cast concrete structures come in many sizes and vary from manufacturer to manufacturer. For this study, representative volumes of dry wells with depths of 2, 4, and $10 \mathrm{ft}$ and their associated horizontal extents (Mershon Concrete, written commun., 2008) were used.

\section{Depth to Water Table}

The depth of the water table below land surface can also be described as the thickness of the unsaturated zone (not accounting for the capillary fringe). A thicker unsaturated zone can store more water and will, therefore, reduce and (or) delay the water reaching the water table beneath a stormwater infiltration basin (Sumner and others, 1999). Evaluation of the unsaturated-zone effects (delayed delivery of recharge to the water table or estimation of storage in the unsaturated zone and subsequent evapotranspiration preventing recharge to the water table) were beyond the scope of this study, in part because of the infinite combinations of thickness, degree of saturation prior to the storm event, and heterogeneity. Neglecting the unsaturated zone is a conservative approach because a simulated water-table mound occurring beneath an infiltration basin will be smaller if storage in the unsaturated zone is included in the simulation. For sites at which the unsaturated zone is considered to be important (for example, sites with a thick unsaturated zone that fail to meet design criteria when the unsaturated zone is neglected), site-specific conditions would have to be included in simulations to provide appropriate results.

\section{Use of Finite Difference Numerical Models to Estimate Groundwater Mounding}

Finite-difference numerical models are useful in the solution of non-linear groundwater-flow problems. Finitedifference models offer the benefit (compared to analytical solutions) of representing highly complex three-dimensional conditions and including site-specific conditions such as variations in aquifer characteristics, basin shape, recharge duration, and other local features in the simulations. The height of the water table beneath stormwater infiltration basins and the surrounding area was simulated for this study using the USGS groundwater-flow model MODFLOW-2000 (Harbaugh and others, 2000).

\section{Model Design}

The models of 10-acre and 1-acre areas having a hypothetical stormwater infiltration basin were designed to simulate the groundwater mounding beneath and near the basin for a fully three-dimensional system with horizontal boundaries that are beyond the radius of influence of the infiltration basin (for modeling purposes assumed to be a simulated $0.01-\mathrm{ft}$ increase in water level). The simulations are transient, running for 36 hours during the period of recharge from the basin to the aquifer. Initial conditions for all simulations include a flat water table and an initial constant aquifer thickness. Beginning each simulation with a flat water table corresponds to a physical system that has recovered from any previous recharge events to a steady-state condition. Although the water table will have a gradient under almost all natural conditions, the gradient is likely to be very small compared to the local gradient caused by groundwater mounding. A pre-existing gradient created by having an initial model stress period with regional recharge and discharge to a surface-water feature (drain) was not used because this led to non-uniform aquifer thicknesses that could not be set to the desired 10,20, and $40 \mathrm{ft}$.

Multiple layers must be included in the model to simulate the effect of vertical anisotropy of permeability. For this study, soil permeability (vertical hydraulic conductivity) is estimated to be one-tenth of horizontal hydraulic conductivity. The models include three layers to make possible the simulation of the vertical component of flow and the effects of vertical anisotropy of permeability. The top layer was modeled as unconfined, whereas the middle and bottom layers were modeled as confined.

\section{Simulation of Groundwater Mounding Beneath Hypothetical Stormwater Infiltration Basins for a 10-Acre Development}

A 10-acre development was chosen as a representative scale for developments that likely would have a hypothetical centralized stormwater collection and infiltration system. The modeled development is rectangular with the stormwater infiltration basin located close to the development boundary (fig. 2).

\section{Model Discretization}

The simulated area is square (fig. 2), 2,300 ft (700 m) on each side (about 120 acres). The grid cells increase from 
$1.65 \mathrm{ft}(0.50 \mathrm{~m})$ on a side in the area of the infiltration basin to $3.3 \mathrm{ft}(1.0 \mathrm{~m})$ and then $6.6 \mathrm{ft}(2.0 \mathrm{~m})$ on a side in the remainder of the model (fig.2). The model has 560 rows and 568 columns, and all 318,080 cells are active in each model layer.

The model has three layers that are of equal saturated thickness (layer 1 is partially saturated, whereas layers 2 and 3 are fully saturated) at the start of the simulation when the water table is flat. For the simulations with an aquifer thickness of $10 \mathrm{ft}$, layers 2 and 3 are each a constant thickness of $3.33 \mathrm{ft}$. The saturated thickness of layer 1 was initially also $3.33 \mathrm{ft}$ but increased throughout the 1.5-day simulation because of recharge. The total thickness (saturated and unsaturated) of layer 1 is $60 \mathrm{ft}$, thick enough that layer 1 is never fully saturated at any location in any simulation. Similarly, for simulations with aquifer thicknesses of 20 and $40 \mathrm{ft}$, the initial saturated thicknesses of the three layers are each $6.66 \mathrm{ft}$ and $13.32 \mathrm{ft}$, respectively.

All of the simulations are transient, lasting 1.5 days (36 hours). This storm duration was chosen because the NJDEP requires that stormwater infiltration basins drain in 3 days or

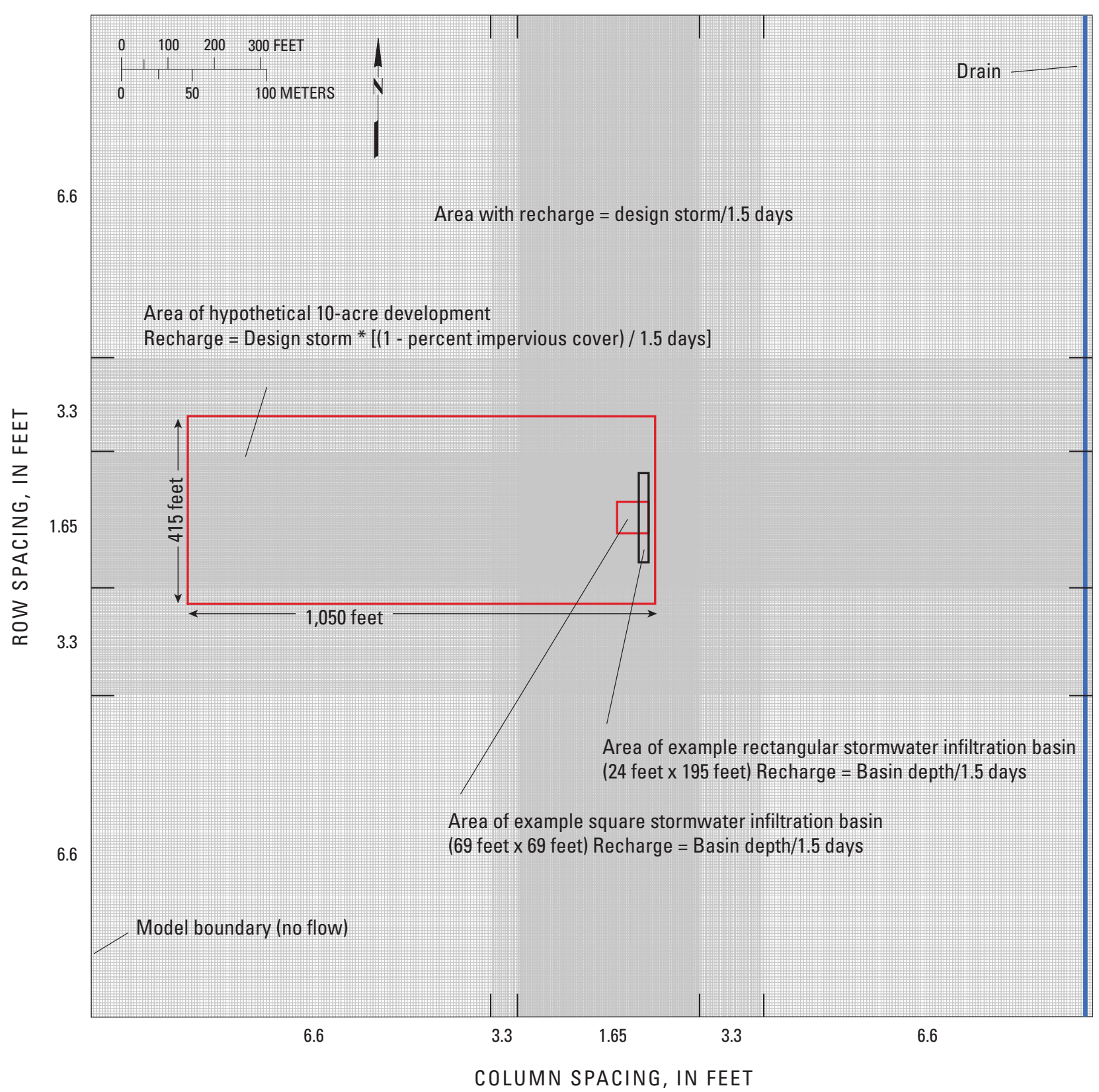

Figure 2. Model grid and boundary conditions of a finite-difference model used to simulate groundwater mounding beneath hypothetical stormwater infiltration basins on a 10 -acre development. 
less to prevent mosquito breeding and, as a factor of safety, that the basins be designed to drain in 1.5 days (or, the basins can be designed to drain in 3 days if the soil permeability is assumed to be one-half the measured value, producing similar estimates of groundwater mounding). Although the NJDEP water-quality design storm duration is 2 hours (New Jersey Administrative Code 7:8-5.5(a)2, 2004), it was assumed that stormwater infiltration basins would capture and store the runoff while it infiltrates over 1.5 days. The 1.5 -day stress period was divided into 16 time steps with an initial time step of 0.0208 day ( 30 minutes) and the time steps increased in length by a factor of 1.2 for each time step. The initial condition is steady-state (flat water table, no recharge, surface-water boundary at the same elevation as the water table), so no initial steady-state stress period was used.

\section{Characteristics Varied to Estimate Groundwater Mounding}

The seven physical characteristics varied to establish a range of simulated groundwater mounds are soil permeability, aquifer thickness, specific yield, infiltration basin shape, basin depth, design storm, and percentage of impervious cover (table 1). Unique combinations of three values of soil permeability, three values of aquifer thickness, two values of specific yield, two basin shapes, two basin depths, two design storm magnitudes, and four percentages of impervious cover required 576 simulations.

Values of soil permeability (vertical hydraulic conductivity, $\mathrm{Kv}$ ) used in the simulations are $0.2 \mathrm{in} / \mathrm{hr}, 1 \mathrm{in} / \mathrm{hr}$, and $5 \mathrm{in} / \mathrm{hr}$. A horizontal to vertical permeability ratio of $10: 1$ was used in all simulations, yielding horizontal hydraulic conductivities (Kh, in units of feet per day more commonly used in groundwater investigations) of $4 \mathrm{ft} / \mathrm{d}, 20 \mathrm{ft} / \mathrm{d}$, and $100 \mathrm{ft} / \mathrm{d}$. These values were chosen because the minimum soil permeability allowed for infiltration basins is $0.2 \mathrm{in} / \mathrm{hr}$ (Sandra Blick, oral commun., 2008), and permeabilities of $5 \mathrm{in} / \mathrm{hr}$ are typical of unconsolidated sediments in New Jersey (see additional discussion in the "Soil Permeability and Aquifer Thickness" section of this report). Aquifer thickness values of 10, 20, and $40 \mathrm{ft}$ were used in this study.

Specific yield in the simulations was either 0.17 or 0.085 (17 or 8.5 percent). Because layer 1 included the water table, the specific yield determined how much water (when added via recharge, for example) could be stored in the aquifer. Specific yield is a function of the pore space available when water has drained from the aquifer. Layers 2 and 3 function as confined aquifers because the thickness does not change with changing head. Layers 2 and 3, therefore, have much lower storage capacity, entered into the model as storativity (which is equal to specific storage multiplied by aquifer thickness). Specific storage (expressed in units of $1 /$ Length) is a function of the compressibility of water and of the aquifer material and is several orders of magnitude less than the porosity (Fetter, 1994, p. 116). For this study, a value of $3.3 \times 10^{-5} \mathrm{ft}^{-1}$ was used in all simulations for specific storage. A sensitivity analysis using a specific storage value for model layers 2 and 3 of $3.3 \mathrm{x}$ $10^{-3} \mathrm{ft}^{-1}$ lowered the maximum head only $0.02 \mathrm{ft}$.

The design storm magnitudes used in this study were 1.25 inches and 0.31 inch. Although the NJDEP water quality design storm is 1.25 inches of rain in 2 hours, the duration of recharge (from the infiltration basin, the developed area, and the undeveloped area) is 1.5 days ( 36 hours). Four percentages of impervious cover were used-10, 20,40, and 80 percent. Infiltration basins were simulated as either 2 or $0.5 \mathrm{ft}$ deep.

The volume of runoff from the hypothetical developed area for each simulation was calculated by multiplying the depth of the design storm by 10 acres (435,600 square feet) by the percentage of impervious cover. The assumed runoff volume is a conservative estimate because no losses (for example, evaporation or storage) are included. The calculated volume of runoff was used to determine the area of the infiltration basin by dividing the volume of runoff by the depth of the basin, either 2 or $0.5 \mathrm{ft}$. For square basins, the lengths of the sides were calculated by taking the square root of the area. For rectangular basins, the length of the long side is eight times the length of the short side. The length of the short side was calculated by dividing the area by eight, then taking the square root.

\section{Model Boundaries, Recharge, and Difference Between Undeveloped and Developed Water Levels}

The lateral and bottom sides of the model shown in fig. 2 are no-flow boundaries. The top is a specified-flux boundary with recharge occurring at the water table. The simulations were for a duration of 1.5 days with a steady infiltration of water during that period. A drain is included near the eastern boundary of the model, $1,000 \mathrm{ft}$ east of the western edge of the simulated infiltration basins. The surface-water drain modeled with the MODFLOW Drain Package was included in the simulations of a 10-acre development to test whether presence or absence of a stream at that distance affected results. The surface-water boundary had no effect on the simulated groundwater mounds because the change in flow to the drain was less than 0.1 percent under pre- and post-development recharge.

The area of the hypothetical development is 10 acres; it is the same for all simulations and is a rectangle, $415 \mathrm{ft}$ in the north/south direction (along model columns) and 1,050 ft in the east/west direction (along rows) (fig. 2). The modeled infiltration basins varied in size according to the input variables, ranging from 570 square feet $\left(\mathrm{ft}^{2}\right)$ to $72,600 \mathrm{ft}^{2}$ in area (table 1), meaning the width of the basin varies from $8.4 \mathrm{ft}$ for the smallest rectangular basin to $270 \mathrm{ft}$ for the largest square basin. The distance from the center to the edge of the basins varies from $4.2 \mathrm{ft}$ to $135 \mathrm{ft}$. The eastern edge of the basin is always along the same line (in the same column), $20 \mathrm{ft}$ west of the development boundary, and is centered in the north/ south direction around the same horizontal line (model row) 
Table 1. Values of variables input to the finite-difference simulations of groundwater mounding beneath hypothetical stormwater infiltration basins on 1-acre and 10-acre developments.

\begin{tabular}{lll}
\hline \multicolumn{1}{c}{ Input variable } & \multicolumn{1}{c}{$\begin{array}{c}\text { Values for a 10-acre development } \\
\text { (centralized stormwater infiltration basin) }\end{array}$} & $\begin{array}{c}\text { Values for a 1-acre development } \\
\text { (individual dry well) }\end{array}$ \\
\hline $\begin{array}{l}\text { Soil permeability } \\
\text { (vertical hydraulic conductivity) }\end{array}$ & $0.2,1.0$, or 5.0 inches/hour & $0.2,1.0$, or 5.0 inches/hour \\
Aquifer thickness & 10,20, or 40 feet & 10,20, or 40 feet \\
$\begin{array}{l}\text { Specific yield } \\
\text { (Sy, pore space available for new storage) }\end{array}$ & 0.085 or 0.17 & 0.085 or 0.17 \\
$\begin{array}{l}\text { Percentage of development to be covered by } \\
\text { impervious material } \\
\text { (for example, rooftops and pavement) }\end{array}$ & $10,20,40$ or 80 percent & $10,20,40$ or 80 percent \\
$\begin{array}{l}\text { Design storm magnitude } \\
\text { (depth of precipitation site-wide that must be }\end{array}$ & 1.25 inches or 0.31 inch & 1.25 inches or 0.31 inch \\
accommodated by infiltration basin) & & 2,4, or 10 feet \\
$\begin{array}{l}\text { Depth of infiltration basin or dry well } \\
\text { Infiltration-basin/dry-well shape }\end{array}$ & 0.5 or 2.0 feet & Square \\
Range of infiltration basin/dry well areas & Square (ratio of sides $1: 1)$ & 11 to 1,800 square feet \\
Number of variable combinations & Rectangular (ratio of sides $1: 8)$ & 432 \\
\hline
\end{tabular}

(fig. 3). The simulated height of the groundwater mounding is calculated and reported at distances from the eastern edge of the basin. Results from the analytical solution (discussed later in this report) are presented in feet from the center of the basin so that an adjustment needs to be made to compare analytical results to those presented in the following section of this report.

The groundwater mound associated with a stormwater infiltration basin is calculated by subtracting the water-level increase associated with precipitation events under predevelopment conditions from that under post-development conditions, using the same aquifer characteristics. Therefore, predevelopment simulations were run for all combinations of selected aquifer characteristics (soil permeability, aquifer thickness, and specific yield) with 0.31 inch or 1.25 inches of recharge applied uniformly over the simulated area in 1.5 days. Post-development simulations were then run for the same combinations of aquifer characteristics with the addition of infiltration basins on a 10-acre developed area. For the simulation, if the developed area has, for example, 10 percent impervious cover, then 90 percent of the storm depth will recharge the aquifer over the 10 -acre area and 10 percent will recharge through the infiltration basin. If the 10 -acre area has $10,20,40$, or 80 percent impervious surface, the developed area receives $90,80,60$, or 20 percent of the recharge, respectively, and the remainder will recharge through the infiltration basin. The area outside the developed area receives the same recharge as predevelopment, and the infiltration basin area receives a depth of recharge equal to the depth of the basin. The simulated water levels under predevelopment conditions were subtracted from simulated water levels post-development to determine the change associated with the addition of impervious surfaces (reducing recharge in those areas) and an infiltration basin (concentrating recharge in a small area).

\section{Results}

The maximum height of simulated groundwater mounds (which occurs under the center of the basin), the maximum extent of 0.25 -ft groundwater mounding, and the height of groundwater mounding at fixed distances from the east (right) edge of the hypothetical stormwater infiltration basin for 10 -acre developments are given in table 2 (located in back of report due to its length). The range of the maximum groundwater-mound heights and of the maximum extent of groundwater mounding height of $0.25 \mathrm{ft}$ for each of the 18 values of the seven aquifer, basin, and design storm variables are shown in box plots in figures 4 and 5, respectively. (The box plots included in this report show results from the synthetic population of hypothetical simulations and do not imply a random distribution.) The maximum simulated groundwater-mound height is $18.5 \mathrm{ft}$ and the minimum is $0.1 \mathrm{ft}$. The median of all 576 simulations of the maximum mound heights is $1.8 \mathrm{ft}$. The maximum extent (east from the eastern edge of the infiltration basins, see figs. 2 and 3) of groundwater mounding of 


\section{Simulation of Groundwater Mounding Beneath Hypothetical Stormwater Infiltration Basins}
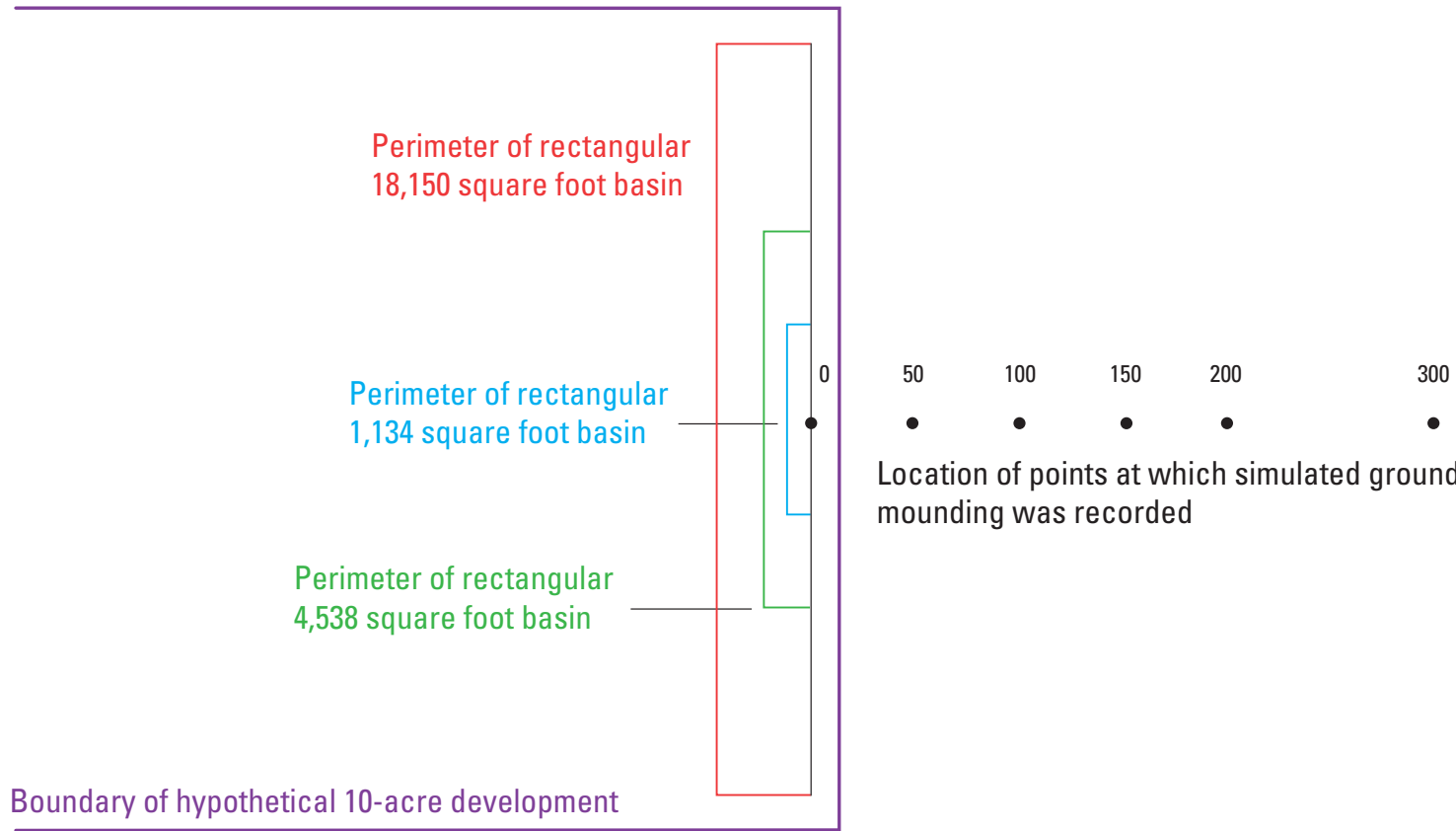

Location of points at which simulated groundwater mounding was recorded

Perimeter of square

1,134 square foot basin

Perimeter of square 4,538 square foot basin 18,150 square foot basin

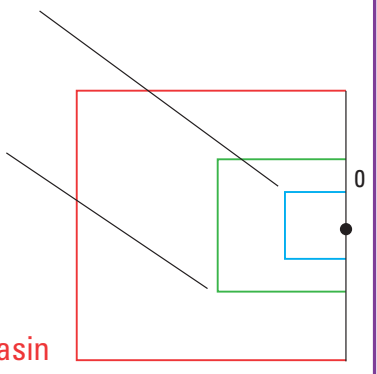

$50 \quad 100 \quad 150 \quad 200$

300

Location of points at which simulated groundwater mounding was recorded

Boundary of hypothetical 10-acre development

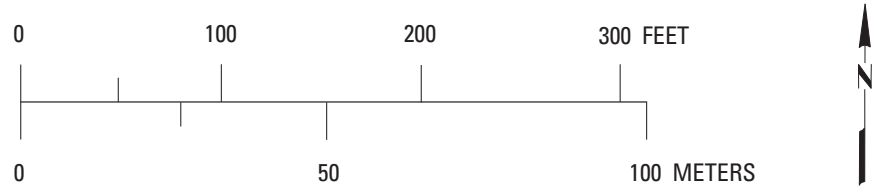

Figure 3. Relative size and placement of selected hypothetical infiltration basins used in simulations of groundwater mounding beneath a 10 -acre development. 
$0.25 \mathrm{ft}$ ranges from 0 to $300 \mathrm{ft}$ with a median of $51 \mathrm{ft}$ for all 576 simulations.

A basin designer needing estimates of the height and extent of groundwater mounding associated with a stormwater infiltration basin for a proposed 10-acre development can find in table 2 the results of a simulation with the same or similar aquifer characteristics and design criteria as the proposed 10 -acre development and can obtain simulated groundwatermound heights and extents. The results in table 2 may be applicable to sites of sizes other than 10 acres. The area of the infiltration basin is a function of a combination of the area of the development, percentage of impervious surface, design storm magnitude, and basin depth; therefore, it is not the area of the development, but the area and depth of the basin, that is the relevant factor for groundwater mounding. Choosing the basin area and depth from table 2 that is equal to or greater than the user's design basin will yield conservative results. For example, the area of a stormwater infiltration basin for a 20 -acre site with 20 percent impervious surface would be the same as that for a 10 -acre site with 40 percent impervious surface and same depth basin. For sites with aquifer characteristics different from those used in this report, the user can choose the closest value that is more conservative. For example, if vertical soil permeability is estimated to be $3 \mathrm{in} / \mathrm{hr}$, using appropriate simulations from table 2 including soil permeability of $1 \mathrm{in} / \mathrm{hr}$ would yield a conservative estimate of maximum groundwater-mound height and $5 \mathrm{in} / \mathrm{hr}$ would yield a conservative estimate of maximum extent of groundwater mounding of $0.25-\mathrm{ft}$. The same approach is appropriate for aquifer thickness (smaller thickness for a conservative estimate of maximum groundwater-mound height and larger thickness for a conservative estimate of maximum extent of groundwater mounding) and basin shape (square basins for a conservative estimate of maximum groundwatermound height and rectangular basins for a conservative estimate of maximum extent of groundwater mounding). Lower values of specific yield and higher values of basin depth produce more conservative estimates of both maximum groundwater-mound height and extent of groundwater mounding.

The simulated systems respond non-linearly to changes in soil permeability and aquifer thickness; increasing soil permeability by a factor of five from 0.2 to $1 \mathrm{in} / \mathrm{hr}$ reduces maximum groundwater-mound heights more than increasing by a factor of five from 1 to $5 \mathrm{in} / \mathrm{hr}$. Therefore, interpolating between (or extrapolating beyond) results for input values between (or beyond) those used in this study may yield incorrect results. More conservative estimates can be obtained by using the closest appropriate simulated input value to the variable measured (or estimated) at a particular site.

The groundwater mounding associated with two or more nearby infiltration basins can be conservatively estimated by simulating the basins separately then adding together the mounding at any given location associated with each individual basin. For example, if identical basins were centered $100 \mathrm{ft}$ apart, the maximum height of the groundwater mound beneath one basin would be increased by the height of the groundwater mound created by the second basin at a distance of $100 \mathrm{ft}$ from the center of that second basin. The height and extent of groundwater mounding are governed by non-linear equations because of the changing thickness of the saturated zone (and, therefore, changing capacity of the aquifer to transmit water). Therefore, there is a known error associated with adding the simulated height of individual groundwater mounds to estimate the combined height. However, the estimate will be conservative and the error will be small if the height of the simulated groundwater mounds is small in comparison to the thickness of the saturated zone. For example, a finite-difference simulation with aquifer and basin characteristics the same as simulation number 218 (table 2) but with two infiltration basins centered $100 \mathrm{ft}$ apart produced maximum groundwatermound heights within $0.02 \mathrm{ft}$ of the result reached by simply adding the effects, and at the midpoint between the two basins the mound height was $1.00 \mathrm{ft}$ lower than the height calculated by adding the two individually simulated groundwater-mound heights at that location.

\section{Maximum Height of Groundwater Mounding}

The box plots in figure 4 show whether a higher value of a variable increases or decreases the maximum groundwatermound height and whether changing the values of some variables changes maximum heights more than changing the values of other variables. For example, groundwater-mound heights are most sensitive to (show the greatest variation with) soil permeability (vertical hydraulic conductivity). Maximum mound heights have the smallest range $(0.1$ to $3.6 \mathrm{ft})$ when soil permeability is set to the highest value of $5 \mathrm{in} / \mathrm{hr}$ and lowest median $(0.6 \mathrm{ft})$ of the 18 variable values. In contrast, maximum heights have the highest minimum $(0.9 \mathrm{ft})$ and highest median ( $3.9 \mathrm{ft}$ ) when soil permeability is $0.2 \mathrm{in} / \mathrm{hr}$. Varying aquifer thickness would have the same effect as varying soil permeability (which, in this study, is one-tenth horizontal hydraulic conductivity) if the values were changed by a factor of 25 (for example, from a thickness of 10 to $250 \mathrm{ft}$ ), but aquifer thickness was changed only by a factor of 4 (10 to $40 \mathrm{ft}$ ) in this study because aquifer thickness usually varies by about an order of magnitude (for example, from 20 to $200 \mathrm{ft}$ ), whereas hydraulic conductivity usually varies by several orders of magnitude at any given site and can vary by seven or more orders of magnitude at a site or between sites. Figure 4 shows that the greatest and median maximum groundwater heights decrease with increasing soil permeability and aquifer thickness.

Groundwater-mound heights decrease when soil permeability, aquifer thickness, or specific yield is increased (and other variables are held constant). In these simulations, changing soil permeability, aquifer thickness, specific yield, basin depth, or basin shape does not change the volume of aquifer recharge; it changes the shape or height of the groundwater mound resulting from the infiltration.

An aquifer with a greater horizontal permeability or aquifer thickness has a greater ability to transmit water away 


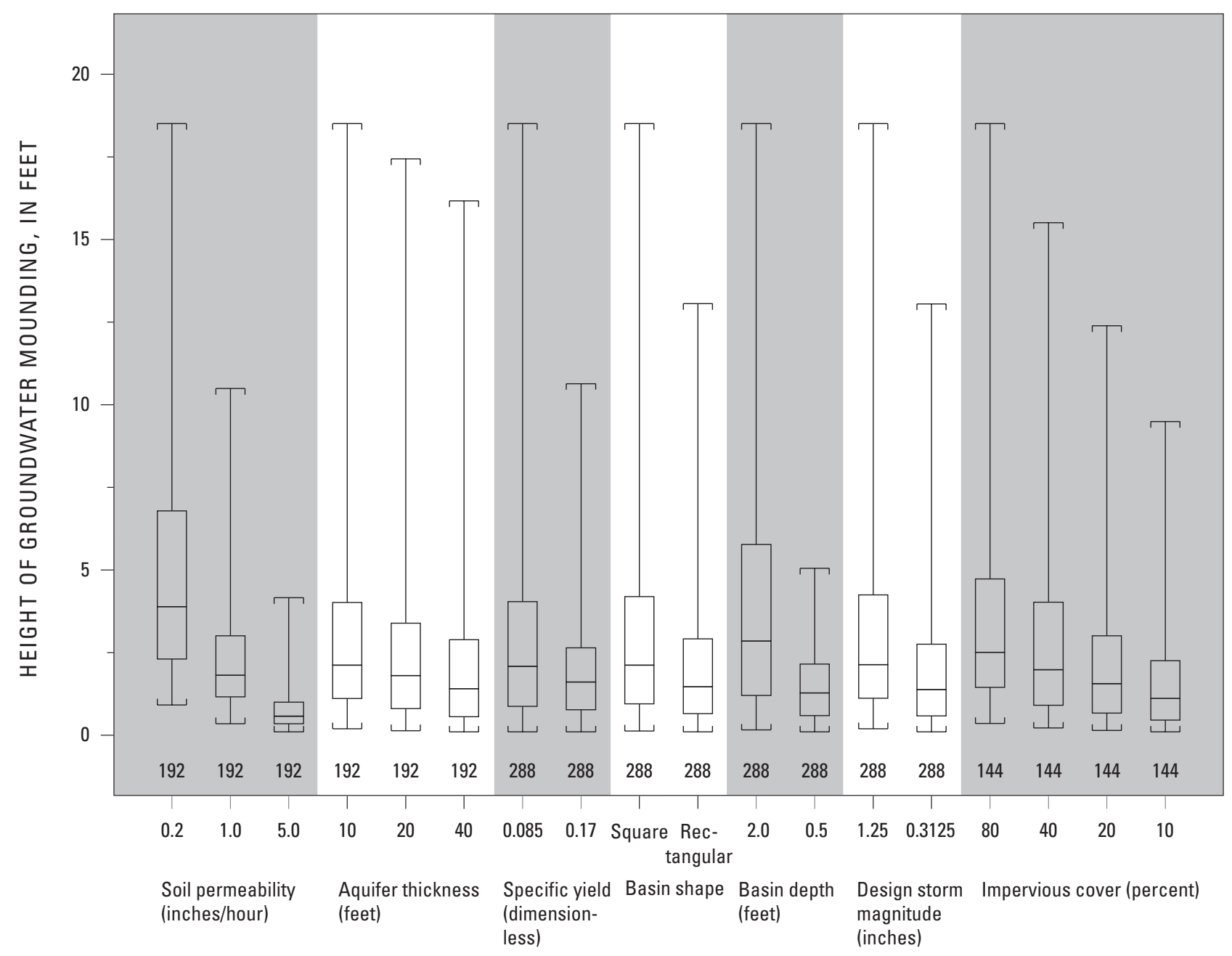

EXPLANATION

\begin{tabular}{l} 
Median percentile \\
25th percentile \\
\hline $144 \quad$ Minimum \\
\hline
\end{tabular}

Figure 4. Range of maximum height of simulated groundwater mounding beneath hypothetical stormwater infiltration basins on a 10 -acre development in relation to aquifer and basin characteristics. 


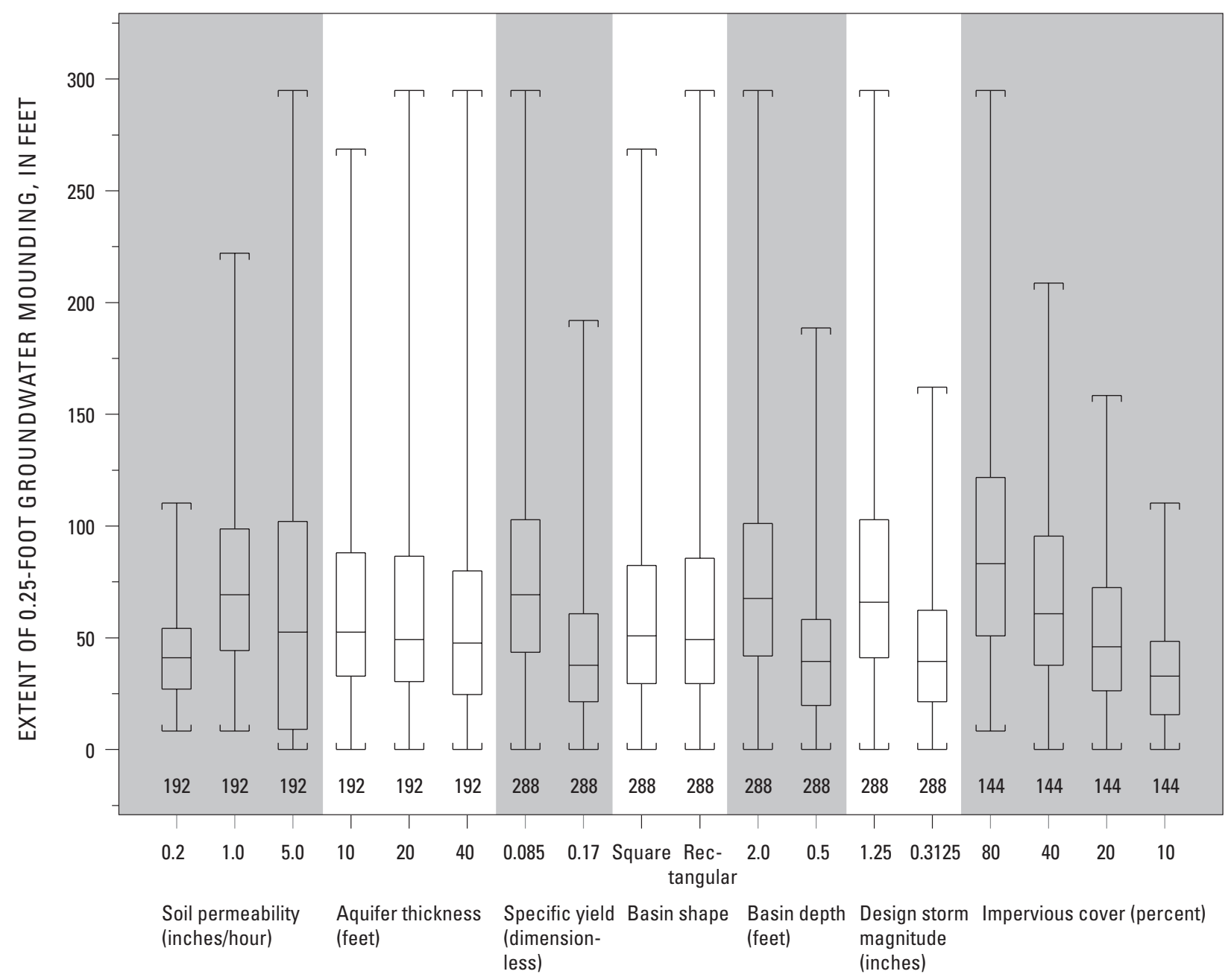

EXPLANATION

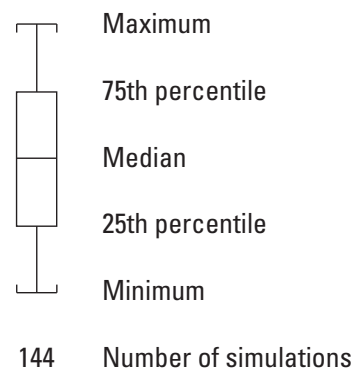

Figure 5. Range of maximum extent of 0.25 -foot simulated groundwater mounding beneath hypothetical stormwater infiltration basins on a 10 -acre development in relation to aquifer and basin characteristics. 
from the source of infiltration than aquifers with lower horizontal permeability or aquifer thickness. Therefore, increasing horizontal permeability decreases the maximum height of groundwater mounding and increases the extent of groundwater mounding. Also, the simulated heights of the groundwater mounds beneath the rectangular basins in this study are lower than beneath the equally sized square basins. Infiltration reaching the water table beneath a rectangular basin has a greater cross-sectional area of aquifer across which to flow away from the basin compared to that of a square basin of equal area. Therefore, the rectangular basin requires less hydraulic head to move the infiltrated water through the aquifer and the simulated groundwater mounds are lower.

The groundwater mound is lower when specific yield is higher because the aquifer can store more water per unit volume of aquifer. The lower height occurs because a given volume of infiltrated water will saturate, for example, one-half the volume of an aquifer when specific yield is doubled.

Linear changes in values of the variables produce nonlinear changes in the groundwater-mound heights. Doubling the specific yield (from 8.5 percent to 17 percent) doubles the storage capacity of the aquifer and, therefore, potentially halves the maximum height of the groundwater mound. The maximum groundwater-mound height of the 576 simulations was $18.5 \mathrm{ft}$, occurring in simulation number 506 , for which the specific yield was 8.5 percent (table 2). Simulation number 505 has the same variable values as number 506 except for specific yield of 17 percent and a maximum groundwatermound height of $10.6 \mathrm{ft}$. The reason the maximum groundwater-mound height for simulation 505 is not exactly half that of simulation 506 is that the simulated unconfined flow system is non-linear and transmissivity changes as the height of the groundwater mound changes.

Basin depth, when changed by a factor of 4 (from 0.5 to $2 \mathrm{ft}$ ), has a substantial effect on the maximum height of groundwater mounding. If there was no lateral flow away from the source of recharge, vertical infiltration of, for example, $2 \mathrm{ft}$ of water into an aquifer with specific yield of 8.5 percent would raise the water level $23.53 \mathrm{ft}$, whereas vertical infiltration (with no lateral flow) beneath a basin depth of $0.5 \mathrm{ft}$ and specific yield of 8.5 percent would raise the water level $5.88 \mathrm{ft}$, one-fourth of that for a basin four times deeper. The simulations for this study do not include flow in the unsaturated zone so water is recharged directly to the water table, and horizontal flow away from the source of recharge begins immediately and continues during the entire 36-hour recharge period, resulting in a maximum groundwater-mound height of $18.5 \mathrm{ft}$ rather than $23.5 \mathrm{ft}$.

Increasing the design-storm magnitude by a factor of 4 (from 0.31 to 1.25 inches) or the percentage of impervious cover by a factor of 8 (from 10 to 80 percent) also has a substantial effect on the maximum height of groundwater mounding. The groundwater-mound height increases when the design storm magnitude or percentage of impervious cover increases (and values of other variables are held constant) because the total volume of infiltrated water also increases. A greater volume of infiltrated water requires a higher head to move that water away from the source of recharge if the physical characteristics of the aquifer are unchanged. Impervious cover percentage and design-storm magnitude have a greater effect on maximum heights of groundwater mounding for the 1 -acre developments (described further on in this report) than for the 10-acre developments because recharge in the 10-acre developments was reduced in the area of the development to account for the effect of impervious surfaces.

The maximum groundwater-mound height $(18.5 \mathrm{ft}$ ) was produced by a simulation with a square basin, maximum basin depth, impervious cover percentage, and storm magnitude ( $2 \mathrm{ft}, 80$ percent, and $1.25 \mathrm{in}$, respectively), and minimum specific yield, soil permeability, and aquifer thickness (8.5 percent, $0.2 \mathrm{in} / \mathrm{hr}$, and $10 \mathrm{ft}$, respectively); therefore, the head required to impart horizontal flow away from the area of recharge is higher than in other simulations.

\section{Maximum Extent of Groundwater Mounding}

The maximum extent of groundwater mounding (defined as a 0.25 -ft water-level increase at a distance measured from the east edge of the hypothetical infiltration basin, see figs. 2 and 3) for 10-acre developments ranges from $0 \mathrm{ft}$ to $300 \mathrm{ft}$ (table 2, fig 5). Of the 576 simulations, 117 had a maximum extent of less than $25 \mathrm{ft}$, and 95 had an extent of more than $100 \mathrm{ft}$, with a median value of $51 \mathrm{ft}$. The maximum extent of a simulated mound of at least $0.01 \mathrm{ft}$ was less than $750 \mathrm{ft}$ for all simulations and $500 \mathrm{ft}$ or greater for 56 of the simulations.

Groundwater mounding of at least $0.25 \mathrm{ft}$ was chosen as the lower limit of mounding considered to be significant. A $0.05 \mathrm{ft}$ difference between pre- and post-development water levels caused by stormwater infiltration is not detectable under field conditions when recharge from precipitation outside of an infiltration structure is increasing water levels by tenths of a foot or more. The value of $0.25 \mathrm{ft}$ was chosen as the amount of significant groundwater level change based on the NJDEP stormwater regulation that sets $0.1 \mathrm{ft}$ as the maximum acceptable change for surface water. Any simulated groundwater value of $0.05 \mathrm{ft}$ is rounded up to $0.1 \mathrm{ft}$ (Sandra Blick, oral commun., 2008), and a surface-water-level increase of $0.05 \mathrm{ft}$ is equivalent to a groundwater-level increase of $0.25 \mathrm{ft}$ if the specific yield of the aquifer was 20 percent $(0.05 \mathrm{ft} / 0.20=$ $0.25 \mathrm{ft}$ ).

The relation between the maximum extent of groundwater mounding and the seven variables tested for this study appears contradictory in some cases. As mentioned in the above discussion of groundwater-mound heights, when other variables are held constant, increasing soil permeability results in a decreased maximum height of groundwater mounding but an increased areal extent. However, the box plots for maximum extent of a 0.25 -ft groundwater mounding for the three values of soil permeability (fig. 5) show that the median extents for soil permeabilities of $0.2 \mathrm{in} / \mathrm{hr}, 1 \mathrm{in} / \mathrm{hr}$, and $5 \mathrm{in} / \mathrm{hr}$ are 41,69 , and $52 \mathrm{ft}$, respectively, so the median of 
the maximum extents increases from the lowest to the middle value of soil permeability but decreases from the middle to the highest value of soil permeability. This outcome also can be seen in some of the results shown in table 2 , for example for simulation numbers 2,4 , and 6 , where the soil permeabilities are $0.2 \mathrm{in} / \mathrm{hr}, 1 \mathrm{in} / \mathrm{hr}$, and $5 \mathrm{in} / \mathrm{hr}$ and the maximum extents of 0.25 -ft groundwater mounding are $41 \mathrm{ft}, 52 \mathrm{ft}$, and $13 \mathrm{ft}$, respectively. The reason the maximum extent is smallest for the highest value of soil permeability is that $0.25 \mathrm{ft}$ was selected as the threshold of significant groundwater mounding. The maximum groundwater-mound heights are 5.40, 1.83, and $0.48 \mathrm{ft}$, and the groundwater-mound heights at $150 \mathrm{ft}$ from the east (right) edge of the infiltration basin are $0.00,0.02$, and $0.04 \mathrm{ft}$ for simulation numbers 2,4 , and 6 , respectively. These results show that the groundwater mound in settings with higher soil permeability is lower at the center and extends farther from the center. However, because the maximum groundwater-mound height in simulation number 6 (soil permeability of $5 \mathrm{in} / \mathrm{hr}$ ) is only $0.48 \mathrm{ft}$, groundwater mounding of $0.25 \mathrm{ft}$ occurs closer to the edge of the basin than in simulations 2 or 4. Because the groundwater mound for a system with higher soil permeability has a lower maximum height but a greater extent than for a system with lower soil permeability (other variables held constant), there is a "crossover" point where the groundwater mounds have the same height (fig. 6). If that "crossover" point is at $0.25 \mathrm{ft}$ or greater, the maximum extent of groundwater mounding of $0.25 \mathrm{ft}$ increases with increasing soil permeability. Because of the $0.25 \mathrm{ft}$ threshold selected for significance, the range of maximum extents is greatest for high soil permeabilities and least for low soil permeabilities. The highest extents occur with the highest permeabilities because the groundwater mound is lower and more areally extensive, as described above. For a few of the simulations with high permeabilities, the groundwater mound is so flat that the $0.25-\mathrm{ft}$ rise does not extend beyond the east edge of the basin, and the maximum extent is zero, lower than any extent that occurs in simulations with lower permeabilities.

The extent of groundwater mounding of $0.25 \mathrm{ft}$ is substantially affected by changing specific yield by a factor of 2 , basin depth by a factor of 4 , design-storm magnitude by a factor of 4 , or percentage of impervious cover by a factor of 8 (fig. 5). The extent is less affected by changing aquifer thickness by a factor of 4 or basin shape from square to rectangular.

Distances in table 2 for the maximum extent of $0.25-\mathrm{ft}$ groundwater mounding and groundwater mounding at fixed locations are given from the east edge of the basin. (This is different than analytical and finite-difference results given in table 4 (farther on in this report), where distances are from the center of the basin.) For the 10-acre developments, the sizes of the hypothetical basins vary from $24 \mathrm{ft}$ to $270 \mathrm{ft}$ on a side for the square basins and $8.4 \mathrm{ft} \times 67 \mathrm{ft}$ to $95 \mathrm{ft} \times 760 \mathrm{ft}$ for the rectangular basins, meaning that the distance from the center to the right edge of the basin varies from $4.2 \mathrm{ft}$ to $135 \mathrm{ft}$. The relevant measurement for adjacent property owners is likely to be the distance from the edge of the basin to existing or proposed structures. For basins with shapes different than square

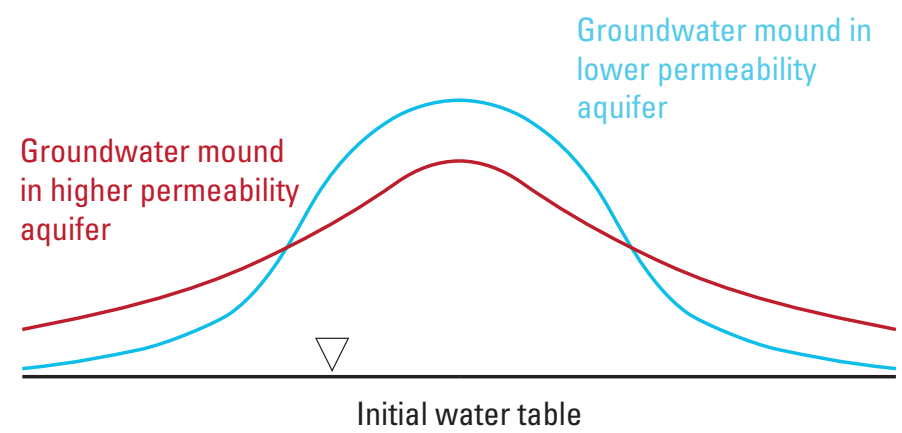

Figure 6. Schematic diagram showing relative shape of groundwater mounding in aquifers of higher and lower soil permeability.

and rectangular (short side to long side ratio 1:8), groundwater mounding effects relative to the edge of the basin can be estimated from the results presented in table 2 by, for example, interpolating between the results for a square basin and a 1:8 rectangular basin to obtain an estimate for a rectangular basin with a short side to long side ratio of 1:4.

\section{Simulation of Groundwater Mounding Beneath Hypothetical Dry Wells for a 1-Acre Development}

Stormwater management can be applied on a development-wide scale (such as the hypothetical 10-acre developments described in the preceding section) or on a property-byproperty scale. For example, some municipalities require that substantial expansion or redevelopment of existing structures includes stormwater management measures to address the increased runoff caused by the expansion (for example, Township of Princeton, 2009). In other circumstances it may be more cost-effective to capture stormwater runoff at each property rather than construct a centralized facility. The simulation of stormwater infiltration at a hypothetical 1-acre development incorporated the assumption that the infiltration structure would be a pre-cast concrete dry well. These structures are constructed with capacities that can range from 600 to 2,700 gallons and with open bottoms and openings on all sides to allow discharge of received water (Mershon Concrete, written commun., 2009).

\section{Model Discretization, Boundaries, and Difference Between Undeveloped and Developed Water Levels}

The modeled area is rectangular, $1,700 \mathrm{ft}(518 \mathrm{~m})$ in the $\mathrm{x}$-direction (along rows) by 1,300 $\mathrm{ft}(400 \mathrm{~m})$ in the $\mathrm{y}$ direction, about 50 acres (fig. 7). The grid cells are $0.5 \mathrm{ft}(0.15 \mathrm{~m})$ on a side in an approximately $60 \mathrm{ft}$ by $60 \mathrm{ft}$ square around the infiltration dry well, increasing to $1 \mathrm{ft}(0.30 \mathrm{~m}), 2 \mathrm{ft}(0.60 \mathrm{~m})$, 
$4 \mathrm{ft}(1.25 \mathrm{~m}), 8 \mathrm{ft}(2.50 \mathrm{~m})$, and $16 \mathrm{ft}(5.00 \mathrm{~m})$ on a side with increasing distance from the hypothetical dry well. The model has 410 rows and 475 columns, and all 194,750 cells are active in each layer.

The model of hypothetical 1-acre developments has the same features as the model of hypothetical 10-acre developments, including three initially equal-thickness layers, transient simulations of 1.5 days, no-flow boundaries on the bottoms and sides, and a specified flux (recharge) boundary on the top. However, the model of the 1-acre development does not have the surface-water boundary (drain) used in the model of the 10-acre system because simulations of the 10-acre developments indicated that a drain located 1,000 $\mathrm{ft}$ from the infiltration basin had an insignificant effect on groundwater mounding. Furthermore, not including a surface-water boundary is conservative because the simulated mound height is higher than would be the case if a nearby drain were present. The same variables were changed (soil permeability, aquifer thickness, specific yield, design storm magnitude, percentage of impervious cover, and basin depth), except for basin shape: all hypothetical basins in the 1-acre developments were square. Also, because there is not a safety concern regarding water depth in a buried structure, drywells are simulated to be $2 \mathrm{ft}, 4 \mathrm{ft}$, or $10 \mathrm{ft}$ deep (Mershon Concrete, written commun., 2009).

Because of the small area of the hypothetical development, 1 acre, the effect of less recharge in the developed area compared to the surrounding area was assumed to be small, and the only recharge input to the model was from the hypothetical dry well. Therefore, the groundwater mounding due to the dry well was calculated by subtracting the initial (flat) water-table height from the final water-table height. (Neglecting the effect of reduced recharge in the developed area is a different approach than was used in the model of the hypothetical 10-acre development described in the previous section of this report.) The hypothetical dry wells were varied in size according to the input variables, but the east edge of the dry well was always located along the same north/south line (model column) and is centered in the north/south direction around the same east/west line (model row), similar to that of the simulation of hypothetical basins in the models of the 10-acre development (figs. 2 and 3).

\section{Results}

Simulated maximum groundwater-mound heights, maximum extent of groundwater mounding of $0.25-\mathrm{ft}$, and groundwater mounding at fixed distances from the right edge of the hypothetical stormwater infiltration dry well for 1-acre developments are given in table 3 (located in back of report due to its length). The range of maximum heights of groundwater mounds and maximum extent of a 0.25 -ft groundwater mounding for each of the 17 values of the six aquifer, basin, and design storm variables are shown in box plots in figures 8 and 9 , respectively. The maximum simulated height of groundwater mounding ranges from 0.01 to $14.0 \mathrm{ft}$ (fig. 8). The median for all 432 simulations of the maximum height of groundwater mounding is $1.0 \mathrm{ft}$. The maximum extent (measured east of the right edge of the dry wells) of the $0.25-\mathrm{ft}$ groundwater mounding ranges from 0 to $100 \mathrm{ft}$ (fig. 9) with a median for all 432 simulations of $10 \mathrm{ft}$.

Results from simulations of hypothetical dry wells on 1-acre developments are similar to those from 10-acre developments: maximum heights of groundwater mounds are most affected by the changes made to soil permeability, and sensitivity to other variables is similar. For further information on the groundwater mounding associated with changes to different variables, see the "Results" section within the "Simulation of Groundwater Mounding Beneath Stormwater Infiltration Basins for a 10-Acre Development" earlier in this report. However, neglecting the effect of reduced recharge in the developed area (away from the dry well) produces results that differ slightly from the simulation of 10-acre developments. For example, maximum groundwater-mounding height and extent of groundwater mounding results for simulations of 1 -acre developments are more sensitive to changes in designstorm magnitude and percentage of impervious cover than changes in dry-well depth, whereas for 10-acre developments changing basin depth had more influence.

The small size of the infiltration dry wells in the 1-acre models and the fixed threshold of $0.25 \mathrm{ft}$ for maximum extent of groundwater mounding lead to different results of simulations of 1-acre developments compared to results of simulations of 10 -acre developments. For example, although increasing soil permeabilities are associated with decreasing heights of the groundwater mound at the center and increasing lateral extent, at the highest permeability the groundwater mound is less than $0.25 \mathrm{ft}$ at the edge of the dry well for more than half of the 1-acre simulations, and the median extent decreases with increased soil permeability or aquifer thickness (fig. 9). In contrast, as was the case for the 10 -acre results, the maximum extent of groundwater mounding of $0.25 \mathrm{ft}$ in simulations of 1-acre developments increases with increased basin depth, design-storm magnitude, or percentage of impervious cover, or decreased specific yield.

\section{Model Limitations}

The initial water-table gradient is simulated to be zero. At some sites, the slope of the water table prior to infiltration can cause the aquifer transmissivity to vary enough that the assumption of an initial flat water table leads to errors in estimated groundwater mounding large enough to affect basin design decisions. If the initial simulated thickness of the water-table (unconfined) aquifer in this study is equal to the smallest thickness measured at a site, the assumption of an initial flat water table is conservative and could be used to minimize errors associated with using results from this study for an area with a sloping water table. 


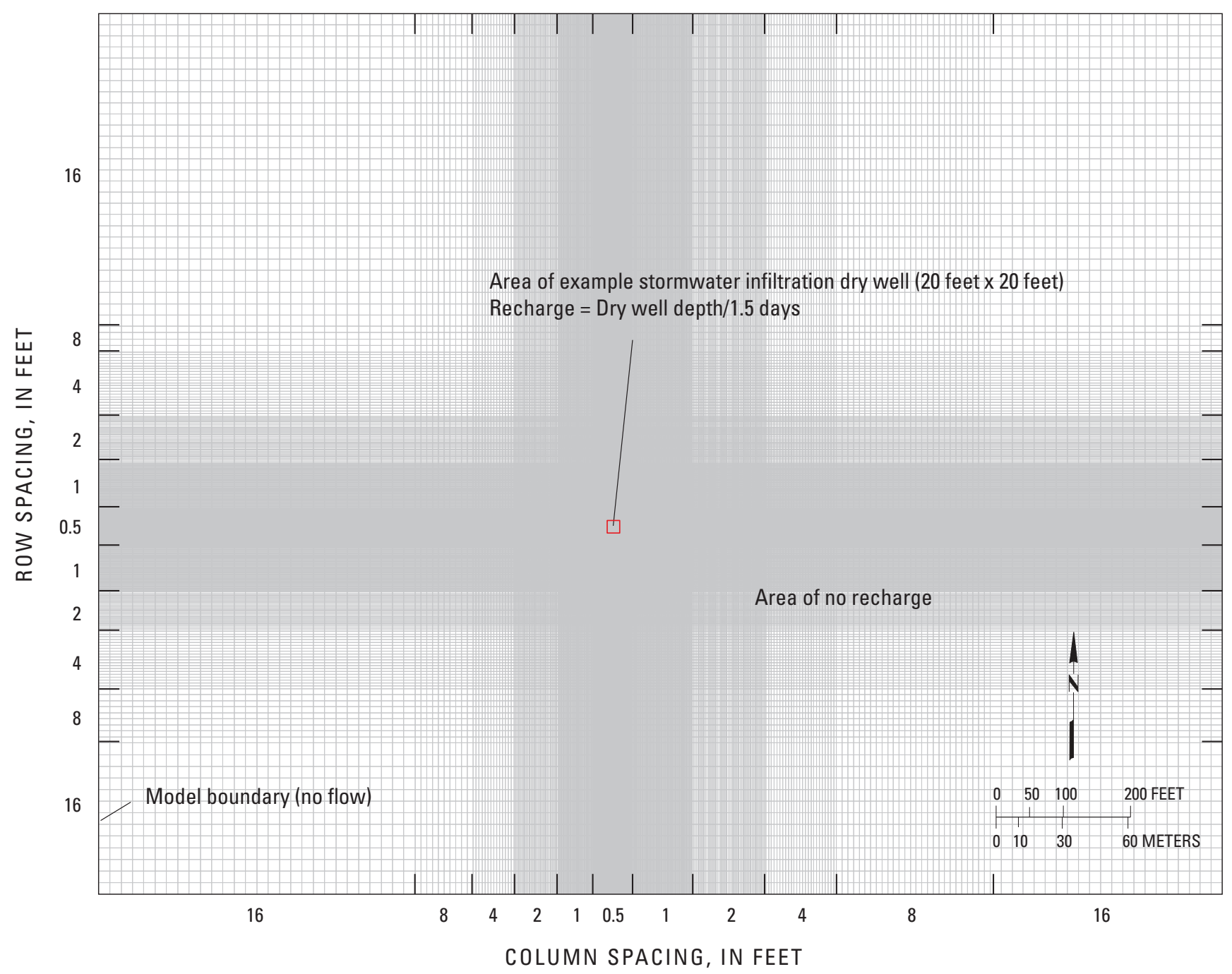

Figure 7. Model grid and boundary conditions of a finite-difference model used to simulate groundwater mounding beneath hypothetical stormwater infiltration basins on a 1-acre development.

The duration of the simulations was 1.5 days with a steady infiltration of the stormwater-basin design volume of water during that period. Infiltration of the same volume of water during a shorter period would result in a higher groundwater mound beneath and near the infiltration basin. Also, there is no evaluation of whether the design volume would infiltrate to the water table within 1.5 days. The simulated recharge was applied directly to the water table, irrespective of the physical plausibility of complete infiltration through the basin bottom and the unsaturated zone. It is possible that in sediments of lower permeability $(0.2 \mathrm{in} / \mathrm{hr})$ the basin would not fully drain in 1.5 days, yet for the simulations it is assumed the water reaches the water table during that period. Methods for calculating whether the infiltration basin will drain in more, less, or exactly 1.5 days are beyond the scope of this study but would need to be applied to confirm that the basin meets the design criteria before using the results of these simulations.

The model used for these simulations, MODFLOW-2000 (Harbaugh and others, 2000), simulates only flow in the saturated zone. Therefore, the simulated stormwater infiltration reaches the water table without attenuation in an unsaturated zone. In reality, there can be substantial storage and time delay in the unsaturated zone that would act to lower the height of the groundwater mound associated with a stormwater event. Because neglecting the unsaturated zone leads to higher simulated groundwater mounds, this approach is conservative.

A finite number of simulations are described for a limited suite of variables, whereas there are an infinite number of combinations of values of variables not included and of properties that were not varied (such as the ratio of vertical to horizontal permeability). Additional simulations would need to be done to estimate the sensitivity of results to properties that 


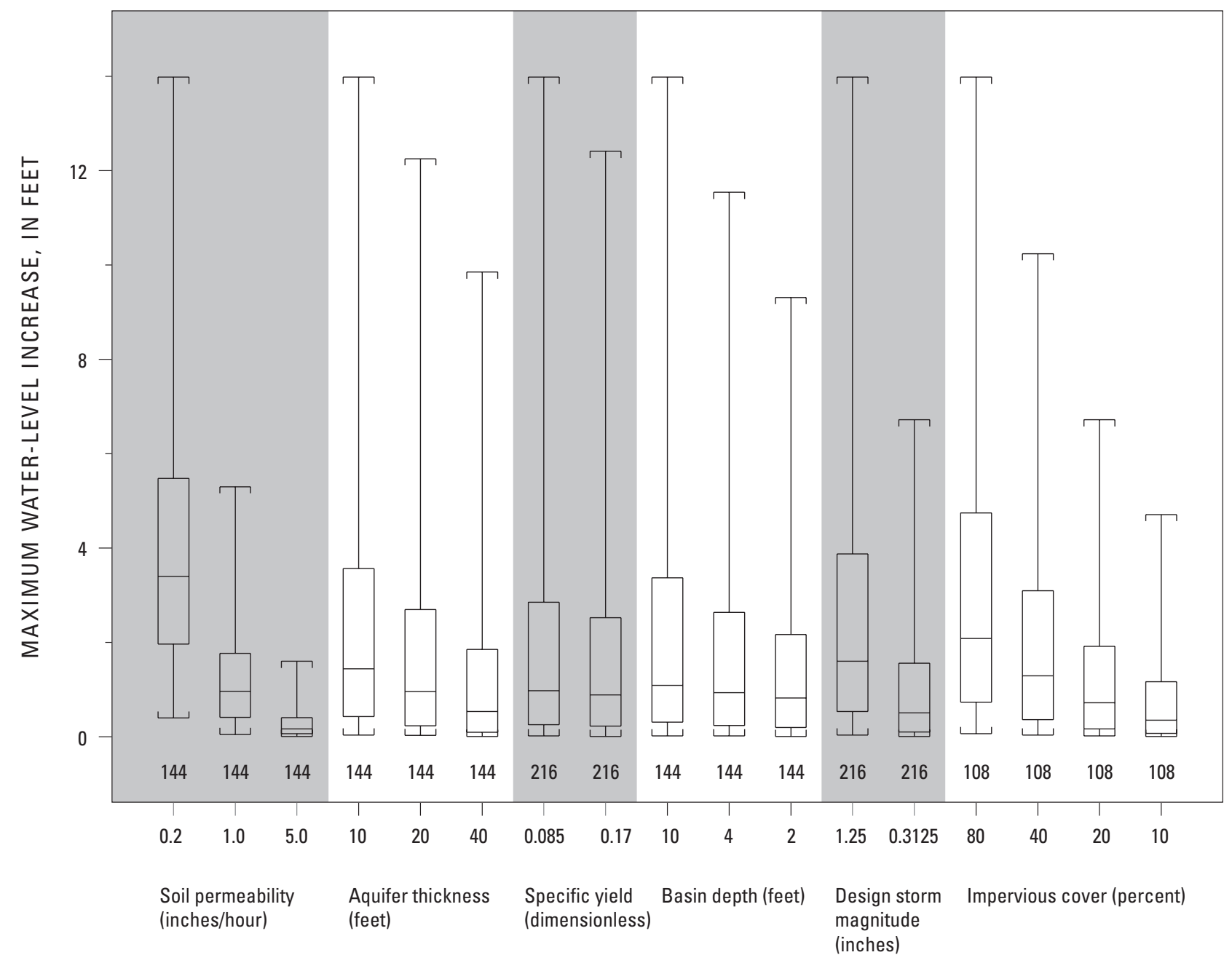

EXPLANATION

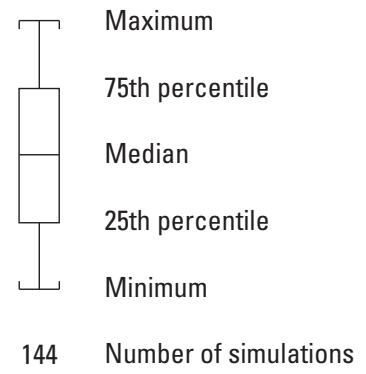

Figure 8. Range of maximum height of simulated groundwater mounding beneath hypothetical stormwater-infiltration dry wells on a 1 -acre development in relation to aquifer and dry well characteristics. 


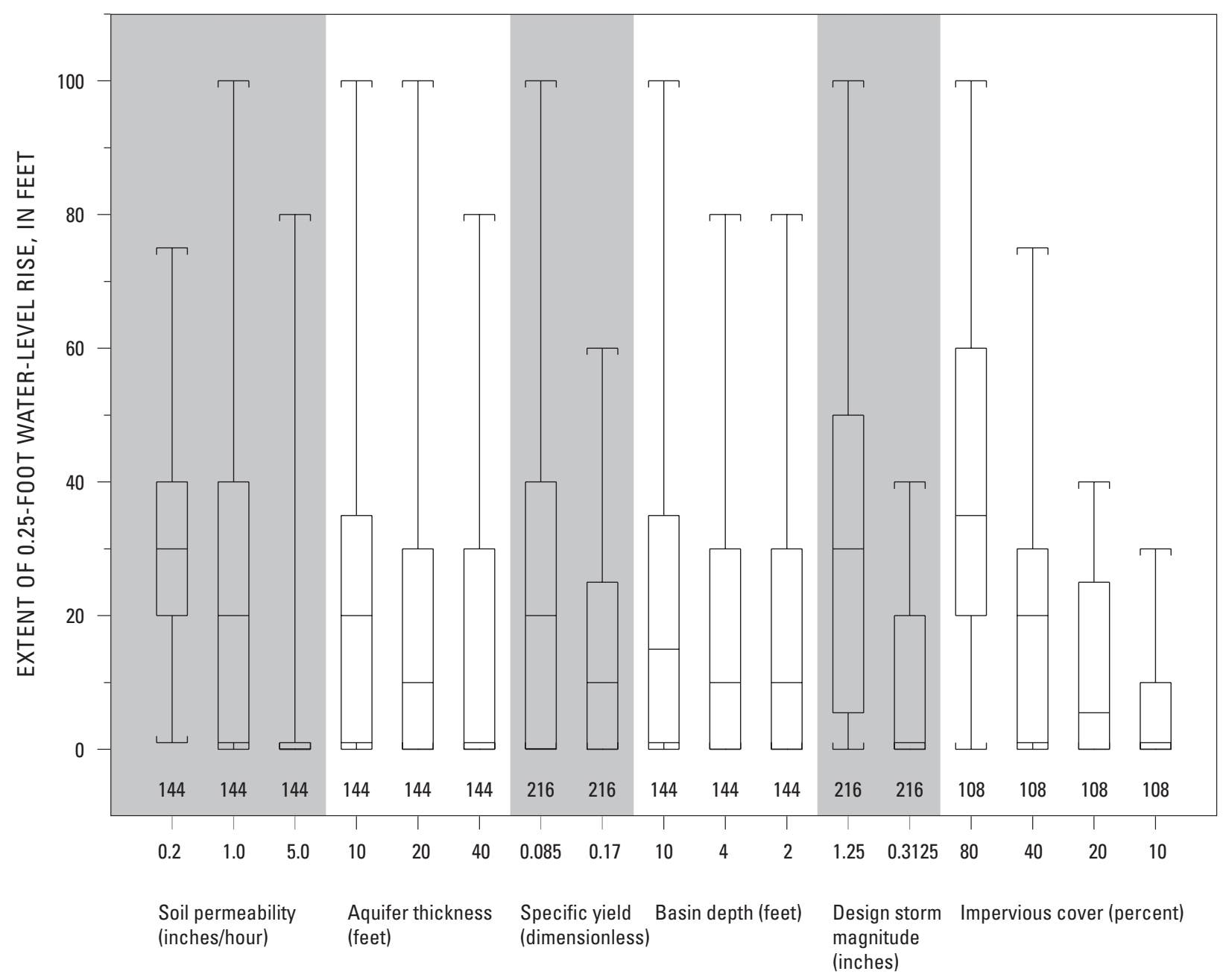

EXPLANATION

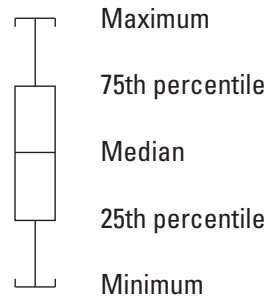

144 Number of simulations

Figure 9. Range of maximum extent of 0.25 -foot simulated groundwater mounding beneath hypothetical stormwater-infiltration dry wells on a 1-acre development in relation to aquifer and dry well characteristics. 
were not changed and to estimate groundwater mounding at sites for which properties are substantially different than those used in this study.

\section{Use of Analytical Equations to Estimate Groundwater Mounding}

Analytical equations (partial differential equations with initial and boundary conditions that mathematically describe, in this case, groundwater flow) can be used to estimate the magnitude and radius of groundwater mounding beneath an infiltration basin or dry well, but the accuracy of the results is limited by simplifying assumptions that are inherent to solving the non-linear differential equations. A number of solutions have been presented over the past 50 years; the most widely cited is that by Hantush (1967).

\section{Description of Hantush Equation}

Hantush (1967) proposed a solution of an equation describing the "growth and decay of groundwater mounds in response to uniform percolation." The Hantush and similar equations are widely implemented (for example, Finnemore, 1995; Zomorodi, 2005) to estimate water-table mounding beneath septic systems and other similar infiltration structures that can reasonably be considered steady-state (infiltration is constant over time). However, few implementations have included the more challenging transient condition (infiltration occurs over a limited duration, then ceases) which is addressed in this study.

Hantush (1967) assumes a water-table aquifer of infinite extent and finite thickness with a horizontal, impermeable base. The solution also includes the Dupuit assumptions of horizontal flow and negligible change of transmissivity with a change in head. The solution Hantush derived making these assumptions provides results that correspond well with similar analytical solutions and some field measurements.

Hunt (1971) proposed a solution that mathematically includes the vertical component of the flow vector that can be significant in groundwater mounding, but the solution has substantial limitations, including a non-solvable integral at the center of the infiltration basin and numerical oscillations beyond the outer edge of the infiltration basin. Hunt's solution does not account for vertical anisotropy of permeability.

Finite-difference numerical simulations of groundwater mounding show that vertical anisotropy can lead to simulated groundwater-mound heights on the order of 15 percent higher than those simulated in either a 1-layer finite-difference model or analytical solution with the assumption that flow is strictly horizontal flow (see the following section of this report "Comparison of Analytical and Finite-Difference Estimates of Groundwater Mounding and Effect of Vertical Layering"). Also, simulations that include storage in, and delayed yield from, the unsaturated zone result in groundwater mounding less than that obtained by neglecting the unsaturated zone (Sumner and others, 1999). Therefore, the height of groundwater mounding is underestimated by the Hantush equation where vertical anisotropy is present and overestimated where an unsaturated zone is present.

Hantush (1967) solves the general two-dimensional groundwater flow equation by making assumptions to create boundary conditions that allow the use of a Laplace transform with respect to time and the Fourier cosine transform with respect to $\mathrm{x}$ and then $\mathrm{y}$ to derive an integral that can be solved. The resulting equation is

$$
\begin{aligned}
& h^{2}-h_{i}^{2}=(w / 2 k)(v t)\left\{S *\left(\frac{l+x}{\sqrt{4 v t}}, \frac{a+y}{\sqrt{4 v t}}\right)+S *\left(\frac{l+x}{\sqrt{4 v t}}, \frac{a-y}{\sqrt{4 v t}}\right)+\right. \\
& \left.S *\left(\frac{l-x}{\sqrt{4 v t}}, \frac{a+y}{\sqrt{4 v t}}\right)+S *\left(\frac{l-x}{\sqrt{4 v t}}, \frac{a-y}{\sqrt{4 v t}}\right)\right\} \\
& \text { where } S *(\alpha, \beta)=\int_{0}^{1} \operatorname{erf}\left(\frac{\alpha}{\sqrt{\tau}}\right) \operatorname{erf}\left(\frac{\beta}{\sqrt{\tau}}\right) d \tau,
\end{aligned}
$$

where

$$
\begin{aligned}
& h=\text { head at a given time after recharge begins; } \\
& h_{i}=\text { initial head (height of the water table above } \\
& \text { the base of the aquifer); } \\
& =\text { recharge (infiltration) rate; } \\
& K=\text { horizontal hydraulic conductivity; } \\
& v \quad=\text { diffusivity, where } v=\mathrm{Kb} / \mathrm{Sy} \text {; } \\
& \underline{b} \quad=\text { average aquifer thickness; } \\
& S_{y} \quad=\text { specific yield; } \\
& t \text { = time elapsed since recharge began; } \\
& l=\text { half-length of the recharge basin; } \\
& a \quad=\text { half-width of the recharge basin; } \\
& x=\text { distance from the center of the recharge } \\
& \text { basin in the } \mathrm{x} \text { direction; } \\
& y=\text { distance from the center of the recharge } \\
& \text { basin in the y direction; } \\
& \alpha=\frac{l+x}{\sqrt{4 v t}} \text { or } \frac{l-x}{\sqrt{4 v t}} \text {; } \\
& \beta=\frac{a+y}{\sqrt{4 v t}} \text { or } \frac{a-y}{\sqrt{4 v t}} ; \\
& \tau=\text { dummy variable of integration; and } \\
& \text { erf }=\text { error function. }
\end{aligned}
$$

The integral in the above equation cannot be solved explicitly and is solved using iterative numerical methods.

\section{Spreadsheet for Solving Hantush Equation}

As part of this study, a spreadsheet was developed to use the Hantush equation (1967) to calculate the magnitude of groundwater mounding. The required input values (aquifer thickness, horizontal hydraulic conductivity, specific yield, basin size, and recharge rate and duration) are straightforward and can be measured or estimated from published values. The 
difficulty of solving the Hantush equation for transient (nonsteady state) flow has prevented it from being widely applied in groundwater-mounding applications. This report provides a tool using readily available software to solve the integrals and allow users to specify input variables and generate reasonable, quantified, reproducible estimates of groundwater mounding beneath stormwater infiltration structures.

The numerical solution used in the Microsoft Excel spreadsheet presented in this report was written by Dr. Arthur Baehr (U.S. Geological Survey (retired), written commun., 2009) to solve the above equation using the numerical integration techniques Simpsons Rule and the Trapezoidal Rule (Chapra and Canale, 1998). Users specify the recharge rate, specific yield, horizontal hydraulic conductivity, basin width and length, and duration of recharge, and the spreadsheet software calculates the maximum height of groundwater mounding and the mounding at user-specified distances from the center of the mound.

The user executes an Excel macro to recalculate water levels if any values are changed, so macros need to be enabled. Although a change entered for any input variable will cause the spreadsheet to automatically recalculate values, the results will not be correct until the macro is executed because the numerical integration requires an estimate of the final result as an input. The macro uses the Excel function "Goal Seek" to converge on a solution where the estimated and calculated water levels are within 0.0001 . The numerical integration uses the error function, which the user may need to add by following the Excel help instructions for ERF:

If this function is not available, and returns the \#NAME? error, install and load the Analysis ToolPak addin.

On the Tools menu, click Add-Ins.

In the Add-Ins available list, select the Analysis ToolPak box, and then click OK.

If necessary, follow the instructions in the setup program.

The values highlighted in yellow/orange in the user interface page of the spreadsheet (fig. 10) are user-specified input values of aquifer and basin characteristics and the distances from the center of the basin for which groundwater-mounding (thickness of the saturated zone) estimates are desired. The

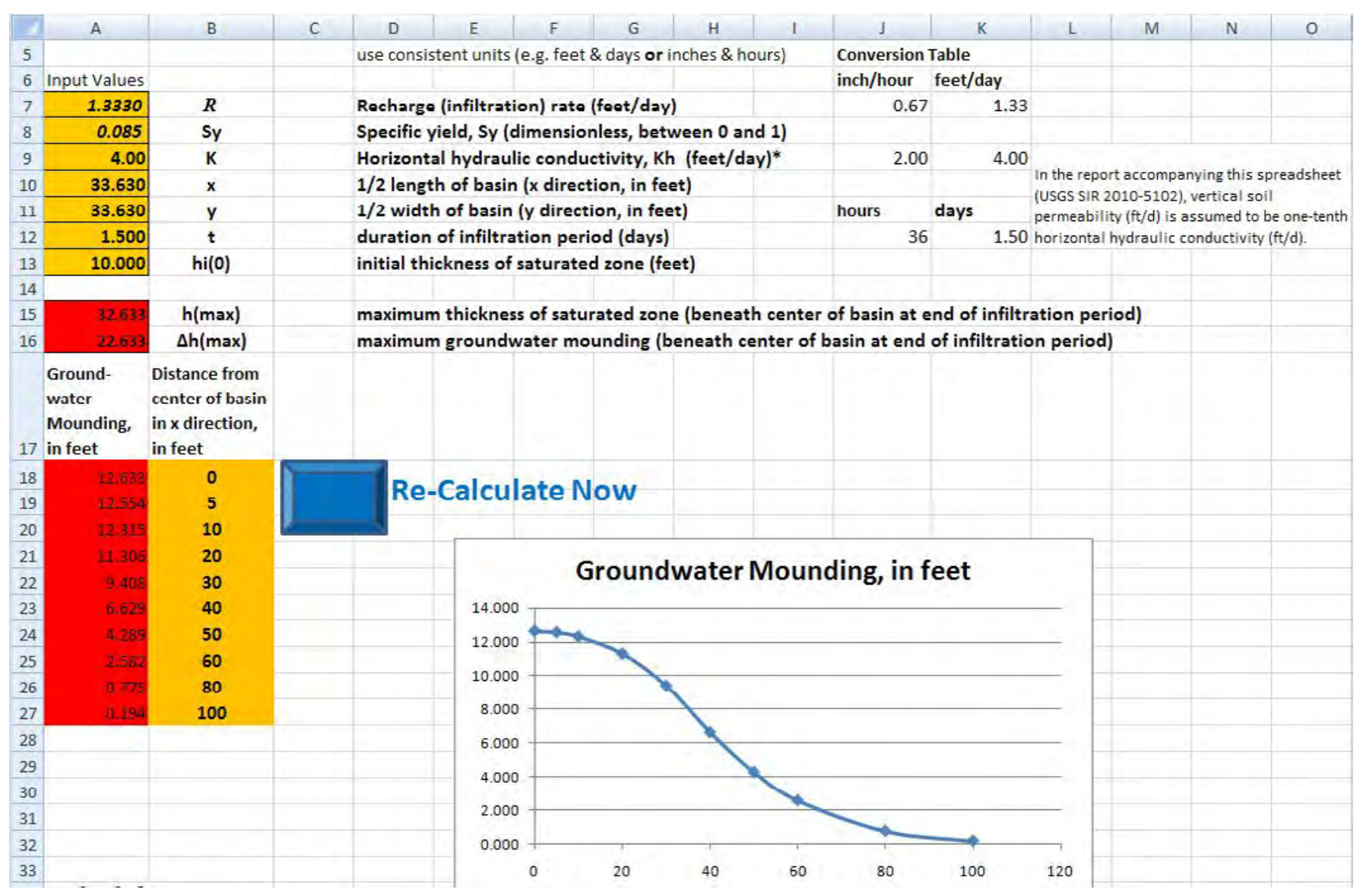

Figure 10. User interface page of spreadsheet for solving the Hantush (1967) equation that describes groundwater mounding beneath an infiltration basin with example input and output. 
values highlighted in red are the calculated maximum height of the groundwater mound, maximum change in water level, and groundwater-mound heights at user-specified distances from the center of the basin. The graph shows the height of the groundwater mound (y axis) above the bottom of the aquifer (datum of zero) in relation to distance (x axis) from the center of the infiltration basin. Each time a value in the spreadsheet is changed, the user must click on the blue button to recalculate the saturated thickness at each of the user-specified points to get valid results.

\section{Comparison of Analytical and Finite- Difference Estimates of Groundwater Mounding and Effect of Vertical Layering}

Results of groundwater-mounding calculations from the spreadsheet described in the preceding section were compared to results from other methods, including the MODFLOW simulations done for this study, to determine accuracy of the methods (table 4, fig. 11). Nicholas Trainor (Rutgers University, Dept. of Applied Mathematics, written commun., 2009) used the mathematical software MAPLE to numerically integrate the Hantush equation (1967) and calculated results identical to those from the spreadsheet solution described in this report. Trainor also solved the Hantush equation in radial coordinates for a circular basin of the same area with similar results. A FORTRAN program, originally written by Sunada and others (1983) and modified by Warner and others (1989), that numerically integrates the Hantush (1967) equation yields maximum groundwater-mound heights that are as much as 15 percent different from those generated for this report with the same input values. The reasons for the discrepancy are not known but may be that the FORTRAN program was written to minimize run-times on 1980s-era personal computers, and the approximations from the numerical integrations introduce more numerical error than those used for this study. Results from numerical integration of the Hunt (1971) equation by Baehr (U.S. Geological Survey, written commun., 2009) show that the Hunt equation cannot be solved at the center of the basin. Also, close to the center of the basin, groundwatermound heights calculated using Hunt's solution increase with distance from the center of the basin (out to $16.4 \mathrm{ft}$ ) instead of decrease and do not correspond closely to values calculated using the Hantush equation (table 4). At distances beyond the edge of the user-specified infiltration basin, groundwatermound heights calculated using the Hunt and Hantush equations are similar.

For comparison with the analytical solution described in the preceding paragraph, finite-difference model (MODFLOW) simulations were conducted with recharge only at the infiltration basin (as opposed to simulations of hypothetical 10 -acre developments described earlier in this report for which recharge was applied over the entire model domain at different rates). For the simulations listed in table 4, a 2-ft-deep infiltration basin was modeled that drains at a steady rate over 1.5 days $(1.33 \mathrm{ft} / \mathrm{d})$. Specific yield was 8.5 percent; the initial saturated aquifer thickness was $10 \mathrm{ft}$; and the infiltration basin was square with an area of about $4,500 \mathrm{ft}^{2}(67 \mathrm{ft}$ on a side). Five MODFLOW models were constructed with 1, 3, 6, 9, and 15 layers to test the sensitivity of results to finer vertical discretization. The 1-layer model is analogous to the Hantush solution, neither of which includes a vertical component of flow. Horizontal hydraulic conductivity was $4 \mathrm{ft} / \mathrm{d}$ and the ratio of vertical anisotropy was 10:1 (vertical hydraulic conductivity (soil permeability) was $0.2 \mathrm{in} / \mathrm{hr}$, which is equivalent to $0.4 \mathrm{ft} / \mathrm{d}$, one-tenth horizontal hydraulic conductivity).

The maximum groundwater-mound height simulated by a finite-difference model that is analogous to the Hantush solution (one layer, two-dimensional flow, recharge applied only over the area of the infiltration basin) is within 3 percent of that from the Hantush equation (table 4). The maximum groundwater-mound height simulated with a 3-layer model is 8 percent $(1.1 \mathrm{ft})$ higher than that from the 1-layer model. The maximum groundwater-mound heights simulated with the 6-, 9-, and 15-layer models are 12,14 , and 15 percent $(1.5,1.7$, and $1.8 \mathrm{ft}$ ) higher, respectively. The maximum groundwatermound heights from the 6-, 9-, and 15-layer models are 3, 4, and 5 percent $(0.4,0.6$, and $0.7 \mathrm{ft})$ higher, respectively, than that from the 3-layer model. In contrast, because the volume of the groundwater mound is constant, the simulated maximum extent of groundwater mounding is greater for models with fewer vertical layers than for models with more vertical layers. Figure 11 shows the sensitivity of the simulated height of the groundwater mound in the hypothetical 10-acre development to the number of layers used in the simulation. The MODFLOW model results are the same at about $45 \mathrm{ft}$ from the center of the basin: between 0 and $45 \mathrm{ft}$ the models with more vertical layers yield higher mound heights than models with less vertical layers; beyond $45 \mathrm{ft}$ models with more vertical layers yield lower mound heights than models with less vertical layers. Input values for aquifer and stormwater-runoff characteristics other than those used to obtain the results shown in table 4 and figure 11 could yield larger departures of mound heights from the analytical and 3-layer models, but the input variables for simulations shown were chosen to obtain a high groundwater mound, and most values for input variables would yield smaller mound-height differences (although potentially larger percentage differences) than shown. These results indicate how sensitive simulated results can be to vertical anisotropy and how results achieved under field conditions could be affected by horizontal low-permeability layers.

Simulations of groundwater mounding beneath infiltration basins will underestimate the maximum height of mounding if vertical anisotropy is not included. Horizontal layers of lower permeability material are common in many geologic environments and have a substantial effect on vertical flow (but have less effect on horizontal flow than over- or underlying higher-permeability layers). Beneath and near an 
Table 4. Calculated and simulated groundwater mounding beneath hypothetical stormwater infiltration basins using selected analytical solutions and finite-difference models.

[solutn, solution; -, not calculated; n/a, not applicable]

\begin{tabular}{|c|c|c|c|c|c|c|c|c|c|}
\hline \multicolumn{2}{|c|}{$\begin{array}{l}\text { Distance from } \\
\text { center of square } \\
\text { stormwater } \\
\text { infiltration } \\
\text { basin }\end{array}$} & \multirow{2}{*}{$\begin{array}{c}\text { Trainor }^{1} \\
\text { solution of } \\
\text { Hantush } \\
\text { water-level } \\
\text { increase } \\
\text { (feet) }\end{array}$} & \multirow{2}{*}{$\begin{array}{c}\text { Spread- } \\
\text { sheet }^{3} \\
\text { solution of } \\
\text { Hantush } \\
\text { water-level } \\
\text { increase } \\
\text { (feet) }\end{array}$} & \multirow{2}{*}{$\begin{array}{c}\text { Sunada }^{4} \\
\text { solution of } \\
\text { Hantush } \\
\text { water-level } \\
\text { increase } \\
\text { (feet) }\end{array}$} & \multirow{2}{*}{$\begin{array}{c}\text { Baehr }^{5} \\
\text { solution of } \\
\text { Hunt }^{6} \\
\text { water-level } \\
\text { increase } \\
\text { (feet) }\end{array}$} & \multirow{2}{*}{$\begin{array}{c}\text { MOD- } \\
\text { FLOW' } \\
\text { 1-layer } \\
\text { water-level } \\
\text { increase } \\
\text { (feet) }\end{array}$} & \multirow{2}{*}{$\begin{array}{c}\text { MOD- } \\
\text { FLOW } \\
\text { 3-layer } \\
\text { water-level } \\
\text { increase } \\
\text { (feet) }\end{array}$} & \multirow{2}{*}{$\begin{array}{c}\text { MOD- } \\
\text { FLOW } \\
\text { 15-layer } \\
\text { water-level } \\
\text { increase } \\
\text { (feet) }\end{array}$} & \multirow{2}{*}{$\begin{array}{c}\text { MOD- } \\
\text { FLOW } \\
\text { 3-layer } \\
\text { 10-acre } \\
\text { simulation } \\
\text { number } 218^{8} \\
\text { water-level } \\
\text { increase } \\
\text { (feet) }\end{array}$} \\
\hline (feet) & (meters) & & & & & & & & \\
\hline 0.0 & 0 & 12.63 & 12.63 & 15.83 & $\mathrm{n} / \mathrm{a}$ & 12.23 & 13.32 & 14.03 & 12.39 \\
\hline 0.3 & 0.1 & 12.63 & 12.63 & - & 10.56 & - & - & - & - \\
\hline 3.3 & 1 & 12.60 & 12.60 & 15.76 & 10.60 & 12.22 & 13.31 & 14.02 & 12.34 \\
\hline 6.6 & 2 & 12.49 & 12.50 & 15.59 & 10.83 & 12.14 & 13.23 & 13.93 & 12.23 \\
\hline 10 & 3.1 & 12.31 & 12.32 & 15.30 & 11.16 & 11.99 & 13.08 & 13.78 & 12.06 \\
\hline 20 & 6 & 11.35 & 11.31 & 13.70 & 11.59 & 11.14 & 12.17 & 12.86 & 11.08 \\
\hline 25 & 7.6 & 10.49 & 10.49 & 12.43 & 11.17 & 10.41 & 11.37 & 12.02 & 10.24 \\
\hline 30 & 9.1 & 9.52 & 9.41 & 10.80 & 10.31 & 9.47 & 10.31 & 10.89 & 9.13 \\
\hline 40 & 12 & 6.79 & 6.63 & 6.95 & 7.62 & 6.99 & 7.32 & 7.57 & 6.30 \\
\hline 50 & 15 & 4.31 & 4.29 & 4.22 & 4.55 & 4.86 & 4.72 & 4.62 & 4.03 \\
\hline 75 & 23 & 1.05 & 1.07 & 1.01 & 0.23 & 1.46 & 1.10 & 0.88 & 0.97 \\
\hline 100 & 31 & 0.19 & 0.19 & 0.18 & 0.15 & 0.32 & 0.27 & 0.25 & 0.25 \\
\hline 150 & 46 & - & 0.01 & 0.01 & 0.04 & 0.01 & 0.02 & 0.02 & 0.02 \\
\hline 200 & 61 & 0.00 & 0.01 & 0.01 & -0.02 & 0.00 & 0.00 & 0.00 & 0.00 \\
\hline
\end{tabular}

'Nicholas Trainor, Rutgers University Department of Applied Mathematics, written commun., 2009.

${ }^{2}$ Hantush, M.S., 1967, Growth and decay of groundwater mounds in response to uniform percolation: Water Resources Research, v.3, p. $227-234$.

${ }^{3}$ Excel spreadsheet presented in this report (revised from Arthur Baehr, U.S. Geological Survey (retired), written commun., 2009).

${ }^{4}$ Sunada, D.K., Warner, J.W., and Molden, D.J., 1983, Artificial groundwater recharge, San Luis Valley, Colorado: Colorado Water Resourece Research Institute, Colorado State University, Fort Collins, Co., Research Project Technical Completion Report, Project no. A-050-Colo, 116 p.

${ }^{5}$ Arthur Baehr, U.S. Geological Survey (retired), written commun., 2009.

${ }^{6}$ Hunt, B.W., 1971, Vertical recharge of unconfined aquifers: Journal of Hydraulics Division, American Society of Civil Engineers, v. 97, no. HY7, p. $1017-1030$.

${ }^{7}$ Harbaugh, A.W.,Banta, E.R., Hill, M.C., and McDonald, M.G., 2000, MODFLOW-2000-The U.S. Geological Survey modular ground-water model-User guide to modularization concepts and the ground-water flow process: U.S. Geological Survey Open-File Report 00-92, 121 p.

${ }^{8}$ See table 2 in this report.

infiltration basin there is a large vertical component of flow, and lower-permeability horizontal layers exert more control on vertical flow than intervening higher-permeability layers. Although vertical anisotropy ratios of 3:1 or less are common in cores, the cumulative effect of one or more low-permeability horizontal layers can lead to an overall vertical anisotropy ratio of 10:1 or greater (Freeze and Cherry, 1979, p. 32-33). Thus, vertical permeability measured in a core sample may overestimate the vertical permeability of the full vertical section through which flow will occur. 


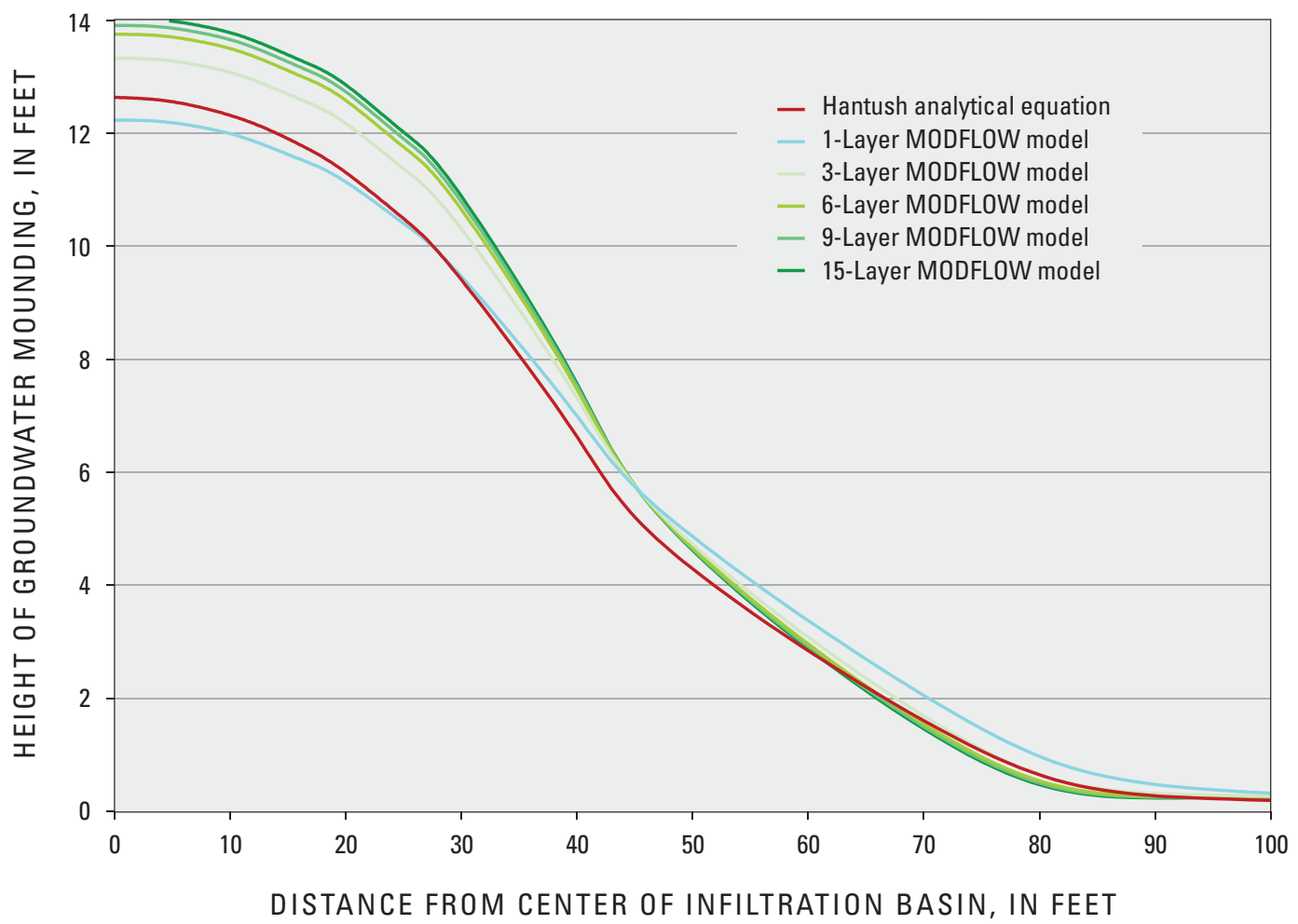

Figure 11. Groundwater mounds beneath hypothetical stormwater infiltration basins calculated using the Hantush equation and simulated with 1-, 3-, 6-, 9-, and 15-layer finite-difference models.

\section{Summary and Conclusions}

In 2004, the New Jersey Department of Environmental Protection (NJDEP) implemented stormwater management rules that include the requirement that "substantial" (greater than 1 acre) new development must have no net loss in groundwater recharge (New Jersey Administrative Code, 2004). Therefore, the amount of recharge that is rejected by new impervious surfaces, such as roofs or driveways, needs to be recharged through engineered structures, such as infiltration basins or dry wells.

Groundwater mounding beneath stormwater infiltration structures was simulated using an analytical method (Hantush, 1967) that incorporates the assumptions of horizontal flow and, therefore, does not account for vertical anisotropy of permeability. Groundwater mounding also was simulated using the finite-difference groundwater-flow model MODFLOW. Three layers of equal initial saturated thickness are used in the three-dimensional MODFLOW simulations that include vertical anisotropy. The simulations do not include any delay or attenuation associated with travel through the unsaturated zone. Also, the volume of water resulting from the design storm falling on impervious surfaces is simulated as steadily recharging the water table below the infiltration basin over 1.5 days.
A 10-acre development was chosen as a representative scale for developments that might have a centralized stormwater collection and infiltration system. The seven physical characteristics varied to establish a range of simulated groundwater mounds beneath a hypothetical infiltration basin for a 10-acre development are soil permeability, aquifer thickness, specific yield, infiltration basin shape, basin depth, design storm, and percentage of impervious cover, and these form 576 unique combinations of the input values. A horizontal to vertical permeability ratio of 10:1 was used in all simulations. Values of vertical soil permeability used in the simulations were $0.2 \mathrm{in} / \mathrm{hr}, 1 \mathrm{in} / \mathrm{hr}$, or $5 \mathrm{in} / \mathrm{hr}$ (equivalent to horizontal hydraulic conductivities of 4, 20, or $100 \mathrm{ft} / \mathrm{d}$ ). Initial aquifer saturated thicknesses used were 10,20, or $40 \mathrm{ft}$, specific yield was 0.17 or 0.085 ( 17 or 8.5 percent), design storm magnitudes were 1.25 inches or 0.31 inch, percentages of impervious cover were $10,20,40$, or 80 percent, and stormwater infiltration basins were either 2 or $0.5 \mathrm{ft}$ deep. Basins were either square or rectangular (with the length of the long side eight times the length of the short side). Recharge to the 10-acre developed area with 10,20,40, or 80 percent impervious surface was 90 , 80,60 , or 20 percent of the design storm depth, respectively; recharge to the area outside the developed area was equal to the design storm magnitude; and the infiltration basin area received a depth of recharge equal to the depth of the basin. 
The maximum height of groundwater mounding calculated during the simulations for the 10 -acre development is $18.5 \mathrm{ft}$, and the minimum is $0.1 \mathrm{ft}$. The median from all 576 simulations of the maximum groundwater mounding is $1.8 \mathrm{ft}$. The maximum extent (measured from the edge of the infiltration basins) of groundwater mounding of 0.25 - $\mathrm{ft}$ ranges from 0 to $300 \mathrm{ft}$ with a median of $51 \mathrm{ft}$ for all 576 simulations. Maximum heights of groundwater mounding are most sensitive to (show the greatest variation with) the three values of soil permeability used. Maximum groundwater-mound heights when soil permeability is $5 \mathrm{in} / \mathrm{hr}$ have the smallest range $(0.1$ to $3.6 \mathrm{ft}$ ) and lowest median $(0.6 \mathrm{ft})$ for the 18 variable values. In contrast, maximum groundwater-mound heights when soil permeability is $0.2 \mathrm{in} / \mathrm{hr}$ have the highest minimum $(0.9 \mathrm{ft})$ and highest median $(3.9 \mathrm{ft})$ for the 18 variable values. Varying the aquifer thickness would have the same effect as varying the soil permeability if the values were changed by a factor of 25 (for example, from 10 to $250 \mathrm{ft}$ ), but values were only changed over a factor of 4 (10 to $40 \mathrm{ft}$ ) in this study.

The maximum groundwater-mound height is higher when one of three variables - soil permeability, aquifer thickness, or specific yield - is decreased (and other variables are held constant). Changing soil permeability, aquifer thickness, specific yield, or basin shape did not change the volume of water infiltrated, it changed the shape or height of the groundwater mound resulting from the infiltration. An aquifer with a greater soil permeability or aquifer thickness can transmit water away from the source of infiltration with less increase in head needed to drive the flow than an aquifer with lower soil permeability or thickness. Therefore, the maximum groundwater-mound height will be lower and the extent of the groundwater mounding will be farther with higher soil permeability. Similarly, the maximum groundwater-mound height beneath a square infiltration basin will be greater than beneath a rectangular basin, but the extent of groundwater mounding (perpendicular to the long edge of the basin) will be greater than beneath a square basin with the same area as the rectangular basin. The maximum groundwater-mound height is lower when specific yield is greater because the aquifer stores more water per unit volume than when the specific yield is lower. For example, a given volume of infiltrated water will saturate one-half the volume of the aquifer when specific yield is doubled.

The maximum groundwater-mound height is higher when the basin depth, design storm magnitude, or percentage of impervious cover is larger (and other variables are held constant) because of the larger total volume of infiltrated water. A larger volume of infiltrated water requires a higher head to move that water away from the source of recharge if the physical characteristics of the aquifer are unchanged. The second greatest effect on maximum groundwater mounding (after increasing soil permeability by a factor of 25 , from 0.2 $\mathrm{in} / \mathrm{hr}$ to $5 \mathrm{in} / \mathrm{hr}$ ) in simulations of the 10 -acre development occurred when the basin depth was increased by a factor of 4 (from $0.5 \mathrm{ft}$ to $2 \mathrm{ft}$ ).
Groundwater mounding of at least $0.25 \mathrm{ft}$ was chosen as the lower limit of mounding considered significant. The relation between the maximum extent of groundwater mounding and variations of the seven variables tested for this study is sometimes contradictory. Because the groundwater mound in an aquifer with higher permeability has a lower maximum height but a greater extent than in an aquifer with lower permeability (other variables held constant), there is a "crossover" point where the groundwater mounds have the same height. If that "crossover" point is at $0.25 \mathrm{ft}$ or greater, the maximum extent of groundwater mounding of $0.25 \mathrm{ft}$ will increase with increased aquifer transmissivity (increased permeability and (or) aquifer thickness).

Stormwater infiltration at a 1-acre development was simulated, and the hypothetical infiltration structure was simulated as a pre-cast concrete dry well. Unique combinations of three values of soil permeability, three values of aquifer thickness, two values of specific yield, three dry-well depths, two design storm magnitudes, and four percentages of impervious cover required 432 simulations, with the same input values as used for simulations of the 10-acre development except that basin depths of 2, 4, and $8 \mathrm{ft}$ were used for the dry wells.

The maximum simulated height of groundwater mounding for the 1-acre development ranges from 0.01 to $14.0 \mathrm{ft}$. The median from all 432 simulations of the maximum height of groundwater mounding is $1.0 \mathrm{ft}$. The maximum extent of groundwater mounding of $0.25-\mathrm{ft}$ ranges from 0 to $100 \mathrm{ft}$ with a median of $10 \mathrm{ft}$ for all 432 simulations.

Hantush's equation describing the "growth and decay of groundwater mounds in response to uniform percolation" is widely used to estimate water-table mounding beneath septic systems and other steady-state conditions. However, fewer implementations have included the more challenging transient condition (infiltration occurs over a limited duration and then ceases). A spreadsheet was developed requiring input values (aquifer thickness, horizontal hydraulic conductivity (assumed in this study to be 10 times vertical soil permeability), specific yield, basin size, and recharge rate and duration) that are straightforward and can be measured or estimated. Users specify the recharge rate, specific yield, horizontal hydraulic conductivity, basin width and length, and duration of recharge, and the spreadsheet calculates the maximum height of groundwater mounding and the mounding at user-specified distances from the center of the infiltration basin.

Maximum groundwater-mound height beneath a stormwater infiltration basin simulated with a finite-difference model analogous to the Hantush solution (one layer, horizontal flow only) is within 3 percent of that from the Hantush equation for the set of variable values simulated. The maximum groundwater-mound height simulated with a 3-layer model (using the same input variables) is 8 percent $(1.1 \mathrm{ft}$ ) higher than that from the 1-layer model. The maximum groundwatermound height simulated with the 15 -layer model is 15 percent $(1.8 \mathrm{ft})$ higher than that from the 1-layer model and 5 percent higher than that from the 3-layer model $(0.7 \mathrm{ft})$. The increase 
in maximum height of the simulated groundwater mound (and decrease in extent of groundwater mounding) with an increased number of horizontal layers illustrates the importance of the vertical component of flow and the typically lower-vertical-than-horizontal hydraulic conductivity. Inclusion of storage in, and delayed yield from, the unsaturated zone would result in lower simulated groundwater mounds compared to those from simulations that omit the unsaturated zone. Therefore, the height of groundwater mounding is underestimated by the Hantush equation where vertical anisotropy is present and overestimated where an unsaturated zone is present.

Results from this study can be used to estimate groundwater-mound heights for sites of different sizes than 10 acres or 1 acre and (or) with different variables than those used in the simulations. The area of the infiltration basin is a function of the area of the development, percentage of impervious surface, design storm magnitude, and basin depth. Area and depth of the basin, not area of the development, governs groundwater mounding. Choosing the basin area and depth that is equal to or greater than the user's design basin will yield conservative results. For sites with aquifer characteristic values different than those used in this study, a basin designer will obtain a conservative result when a conservative variable value is chosen from among those given in this report. For example, if vertical soil permeability is estimated to be $3 \mathrm{in} / \mathrm{hr}$, using appropriate simulations and including soil permeability of $1 \mathrm{in} / \mathrm{hr}$ would yield a conservative estimate of maximum groundwater-mound height, and soil permeability of $5 \mathrm{in} / \mathrm{hr}$ would yield a conservative estimate of maximum extent of groundwater mounding of $0.25-\mathrm{ft}$. The same approach is appropriate for aquifer thickness (smaller thickness for a conservative estimate of maximum groundwater-mound height and larger thickness for a conservative estimate of maximum extent of groundwater mounding) and basin shape (square basins for a conservative estimate of maximum groundwatermound height and rectangular basins for a conservative estimate of maximum extent of groundwater mounding). Lower values of specific yield and higher values of basin depth are conservative for estimating both maximum groundwatermound height and extent of groundwater mounding.

The simulated systems respond non-linearly to changes in soil permeability and aquifer thickness: increasing soil permeability by a factor of five from 0.2 to $1 \mathrm{in} / \mathrm{hr}$ reduces maximum groundwater-mound heights more than increasing soil permeability by a factor of five from 1 to $5 \mathrm{in} / \mathrm{hr}$. Therefore, interpolating between (or extrapolating beyond) results for input values between (or beyond) those used in this study may yield incorrect results. Conservative estimates can be obtained by using the value for a variable that is closest to the value measured (or estimated) at a particular site.

The groundwater mounding associated with two or more nearby infiltration basins can be estimated by modeling the basins separately then adding together the resulting mounding. Because of non-linearities, adding separately simulated groundwater mounds will overestimate the groundwater-mound height, a conservative result.

\section{References Cited}

Anderson, M.P., and Woessner, W.W., 1991, Applied groundwater modeling: Simulation of flow and advective transport: San Diego, Calif., Academic Press, 381 p.

Baumann, P., 1952, Groundwater movement controlled through spreading: Transactions, American Society of Civil Engineers, v. 117, p. 1024-1060.

Carleton, G.B., Welty, Claire, and Buxton, H.T., 1999, Design and analysis of tracer tests to determine effective porosity and dispersivity in fractured sedimentary rocks, Newark Basin, New Jersey: U.S. Geological Survey WaterResources Investigations Report 98-4126A, 80 p.

Cauller, S.J., and Carleton, G.B., 2006, Hydrogeology and simulated effects of ground-water withdrawals, KirkwoodCohansey aquifer system, Upper Maurice River basin area, New Jersey: U.S. Geological Survey Scientific Investigations Report 2005-5258, 48 p.

Chapra, S.C., and Canale, R.P., 1998, Numerical methods for engineers ( $3 \mathrm{~d}$ ed.): Boston, Mass., WCB/McGraw-Hill, $924 \mathrm{p}$.

Charles, E.G., Storck, D.A., and Clawges, R.M., 2001, Hydrology of the unconfined aquifer system, Maurice River area: Maurice and Cohansey River basins, New Jersey, 1994-95: U.S. Geological Survey Water-Resources Investigations Report 01-4229, 5 pls.

Engineering Software, Inc., 2006, MODRET computer program for simulation of infiltration from stormwater retention ponds: Sandy, Utah, Scientific Software Group, 1 disc.

Fetter, C.W., 1994, Applied Hydrogeology (3d ed.): New York, N.Y., Macmillan College Publishing Company, 691 p.

Finnemore, E.J., 1995, A program to calculate ground-water mound heights: Ground Water, v. 33, no. 1, p. 139-143.

Freeze, R.A., and Cherry, J.A., 1979, Groundwater: Englewood Cliffs, N.J., Prentice-Hall, 604 p.

Gill, H.E., 1962, Ground-water resources of Cape May County, New Jersey, saltwater invasion of principal aquifers: New Jersey Department of Conservation and Economic Development, Special Report 18, 171 p.

Glover, R.E., 1960, Mathematical derivations as pertain to groundwater recharge: Fort Collins, Colo., U.S. Department of Agriculture Agricultural Research Service, 81 p. 
Hantush, M.S., 1967, Growth and decay of groundwater mounds in response to uniform percolation: Water Resources Research, v. 3, p. 227-234.

Harbaugh, A.W., Banta, E.R., Hill, M.C., and McDonald, M.G., 2000, MODFLOW-2000, The U.S. Geological Survey modular ground-water model-User guide to modularization concepts and the ground-water flow process: U.S. Geological Survey Open-File Report 00-92, 121 p.

Hunt, B.W., 1971, Vertical recharge of unconfined aquifers: Journal of Hydraulic Division, American Society of Civil Engineers, v. 97, no. HY7, p. 1017-1030.

Johnson, M.J., and Charles, E.G., 1997, Hydrology of the unconfined aquifer system, Salem River area: Salem River and Raccoon, Oldmans, Alloway, and Stow Creek basins, New Jersey, 1993-94: U.S. Geological Survey WaterResources Investigations Report 96-4195, 5 pls.

Johnson, M.J., and Watt, M.K., 1996, Hydrology of the unconfined aquifer system, Mullica River basin, New Jersey, 1991-92: U.S. Geological Survey Water-Resources Investigations Report 94-4234, 6 pls.

Kauffman, L.J., Baehr, A.L., Ayers, M.A., and Stackelberg, P.E., 2001, Effects of land use and travel time on the distribution of nitrate in the Kirkwood-Cohansey aquifer system in southern New Jersey: U.S. Geological Survey WaterResources Investigations Report 01-4117, 49 p.

Latinopoulos, P., 1981, The response of groundwater to artificial recharge schemes: Water Resources Research, v. 17, no. 6, p. 1712 .

Latinopoulos, P., 1984, Periodic recharge to finite aquifers from rectangular areas: Advances in Water Resources, v. 7, p. 137-140.

Manglik, A, Rai, S.N., and Singh, R.N., 1997, Response of an unconfined aquifer induced by time varying recharge from a rectangular basin: Water Resources Management, v. 11, p. 185-196.

Manglik, A, Rai, S.N., and Singh, R.N., 2003, Modelling of aquifer response to time varying recharge and pumping from multiple basins and wells: Journal of Hydrology, v. 292 , no. $1-4$, p. $23-29$.

Marino, M.A., 1974, Water table fluctuations in response to recharge: Journal of Irrigation and Drainage Division, American Society of Civil Engineers, v. 100, no. IR2, p. 117-125.

Modica, Edward, 1996, Simulated effects of alternative withdrawal strategies on ground-water-flow patterns, New Jersey Pinelands: U.S. Geological Survey Water-Resources Investigations Report 95-4133, 46 p.
Natural Resources Conservation Service, 2009, Web Soil Survey: U.S. Department of Agriculture, Natural Resources Conservation Service soils database, accessed November, 19, 2009, at http://websoilsurvey.nrcs.usda.gov/app/WebSoilSurvey.aspx.

New Jersey Administrative Code 7:8, 2004, Stormwater management rules: State of New Jersey, Trenton, N.J., accessed November 2, 2009, at http://www.nj.gov/dep/rules/adoptions/2004_0202_watershed.pdf.

New Jersey Geological Survey, 2008, Horizontal hydraulic conductivity summary: New Jersey Geological Survey Hydro Database, accessed November 20, 2009, at http:// www.state.nj.us/dep/njgs/geodata/dgs02-1.htm.

Nicholson, R.D., McAuley, S.D., Barringer, J.L., and Gordon, A.D., 1996, Hydrogeology of, and ground-water flow in, a valley-fill and carbonate-rock aquifer system near Long Valley in the New Jersey Highlands: U.S. Geological Survey Water-Resources Investigations Report 93-4157, 159 p.

Poeter, Eileen, McCray, John, Thyne, Geoffry, and Siegrist, Robert, 2005, Guidance for evaluation of potential groundwater mounding associated with cluster and high-density wastewater soil absorption systems: Project number WU-HT-02-45, prepared for the National Decentralized Water Resources Capacity Development Project Washington University, St. Louis, Mo., by the International Groundwater Modeling Center, Colorado School of Mines, Golden, Colo., 97 p.

Pope, D.A., and Watt, M.K., 2005, Use of a ground-water flow model to delineate contributing areas to the Puchack well field, Pennsauken Township and vicinity, Camden County, New Jersey: U.S. Geological Survey Scientific Investigations Report 2004-5101, 47 p.

Rai, S.N., and Singh, R.N., 1981, A mathematical model of water-table fluctuation in a semi-infinite aquifer induced by localised transient recharge: Water Resources Research, v. 17, p. 1028-1032.

Rai, S.N., Manglik, A., and Singh, R.N., 1994, Water table fluctuation in response to transient recharge from a rectangular basin: Water Resources Management, v. 8, p. 1-10.

Rao, N.H., and Sarma, P.B.S., 1981, Ground-water recharge from rectangular areas: Ground Water, v. 19, no. 3, p. $270-274$.

Reilly, T.E., 2001, System and boundary conceptualization in ground-water flow simulation: U.S. Geological Survey Techniques of Water-Resource Investigation 03-B8, 29 p. 
Ritter, M.E., 2006, The physical environment: an introduction to physical geography: Stevens Point, Wisc., University of Wisconsin, accessed August 7, 2009, at http://www.uwsp. edu/gEo/faculty/ritter/geog101/textbook/soil_systems/soil_ development_soil_properties.html.

Sumner, D.M., and Bradner, L.A., 1996, Hydraulic characteristics and nutrient transport and transformation beneath a rapid infiltration basin, Reedy Creek Improvement District, Orange County, Florida: U.S. Geological Survey WaterResources Investigations Report 95-428, 51 p.

Sumner, D.M., Rolston, D.E., and Marino, M.A., 1999, Effects of unsaturated zone on ground-water mounding: Journal of Hydrologic Engineering, v. 4, no.1, p. 65-69.

Sunada, D.K., Warner, J.W., and Molden, D.J., 1983, Artificial groundwater recharge, San Luis Valley, Colorado: Fort Collins, Colo., Colorado Water Resources Research Institute, Colorado State University, Research Project Technical Completion Report, Project no. A-050-Colo, 116 p.

Township of Princeton, 2009, Code of the Township of Princeton, Mercer County, New Jersey, amended through October 5, 2009: Princeton, N.J., accessed December 20, 2009, at http://clerkshq.com/default.ashx?clientsite=princeton- $n j$.

Warner, J.W., Molden, D.J., Chehata, Mondher, and Sunada, D.K., 1989, Mathematical analysis of artificial recharge from basins: Water Resources Bulletin, v. 25, no. 2, p. 401-411.

Zapecza, O.S., 1989, Hydrogeologic framework of the New Jersey Coastal Plain: U.S. Geological Survey Professional Paper 1404-B, 49 p.

Zomorodi, Kaveh, 2005, Simplified solutions for groundwater mounding under stormwater infiltration facilities: Proceedings of the American Water Resources Association 2005 annual Water Resources Conference, November 7-10, 2005, Seattle, Washington, $4 \mathrm{p}$. 


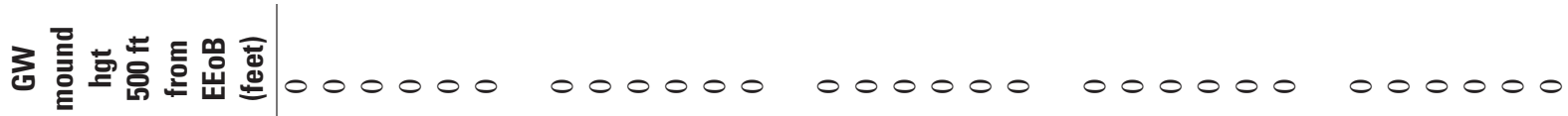

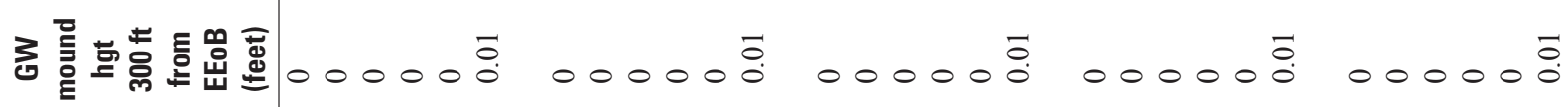

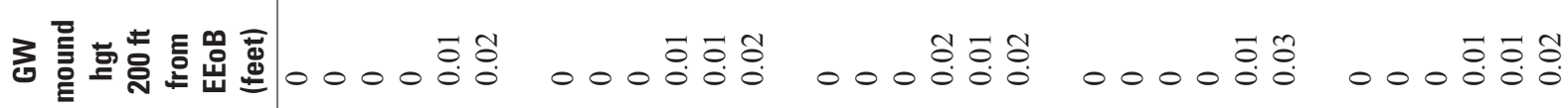

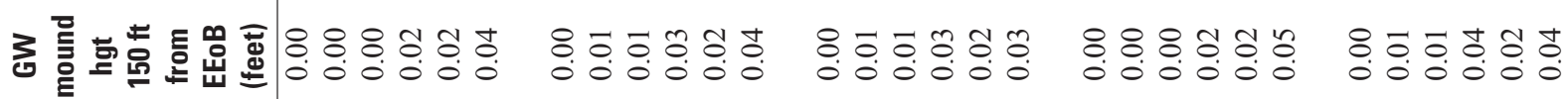

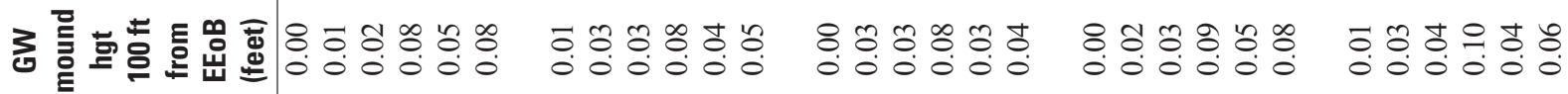

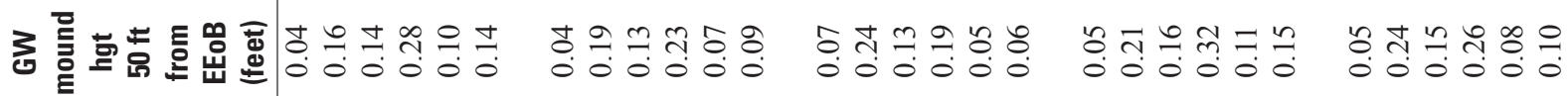

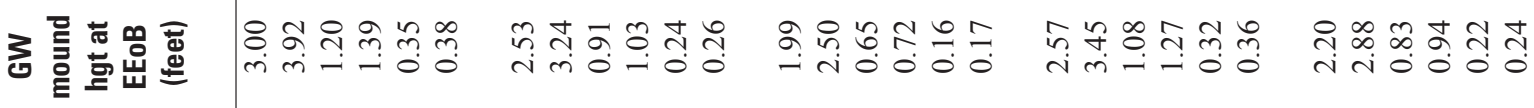

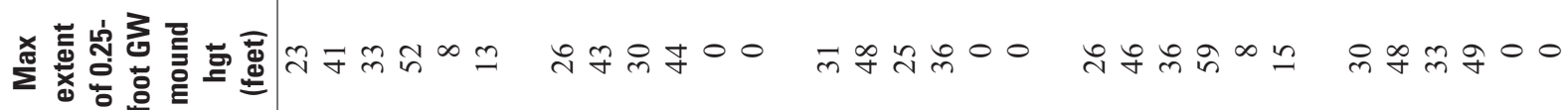

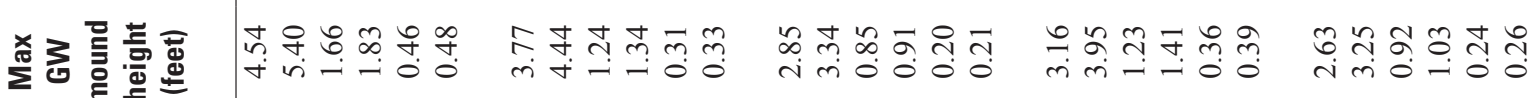

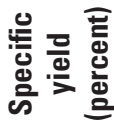

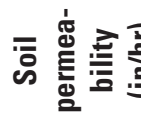

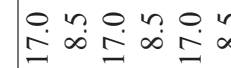
on on in n ononon n o no non on in in o in 亲苍总 ô-

กับ ก

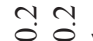

กุช $\infty=\infty$ $=\infty$ 스

器昡

으으으으으 유유 유유 아아의의우

으으으으으으

ํํํํํํํำ 言总离

$\bar{x} \bar{x} \bar{x} \bar{x} \bar{x}$

$\vec{x} \bar{x} \vec{x} \bar{x}-$

$\vec{x} \nabla \vec{x}-\vec{x}$

$\infty \infty \infty \infty \infty \infty \infty \infty \infty \infty \infty \infty$

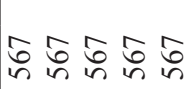
言 흥 Ф $\frac{0}{5}$ 言

$4 \sin 4 \sin 4 \mathrm{n}$

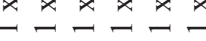
$x \not x \times x \not x$ $\triangle x \times x x x$

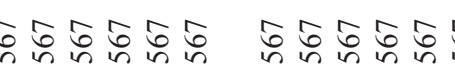

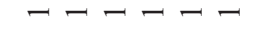
- $\rightarrow-ー-ー$ (n)

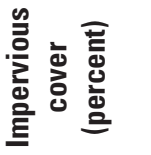

m.

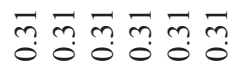

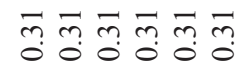

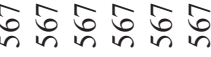

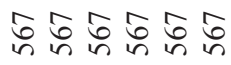

000000

으으으으으으

으으으으으으

으으으으으으

으으으으으으

으으으으으으 


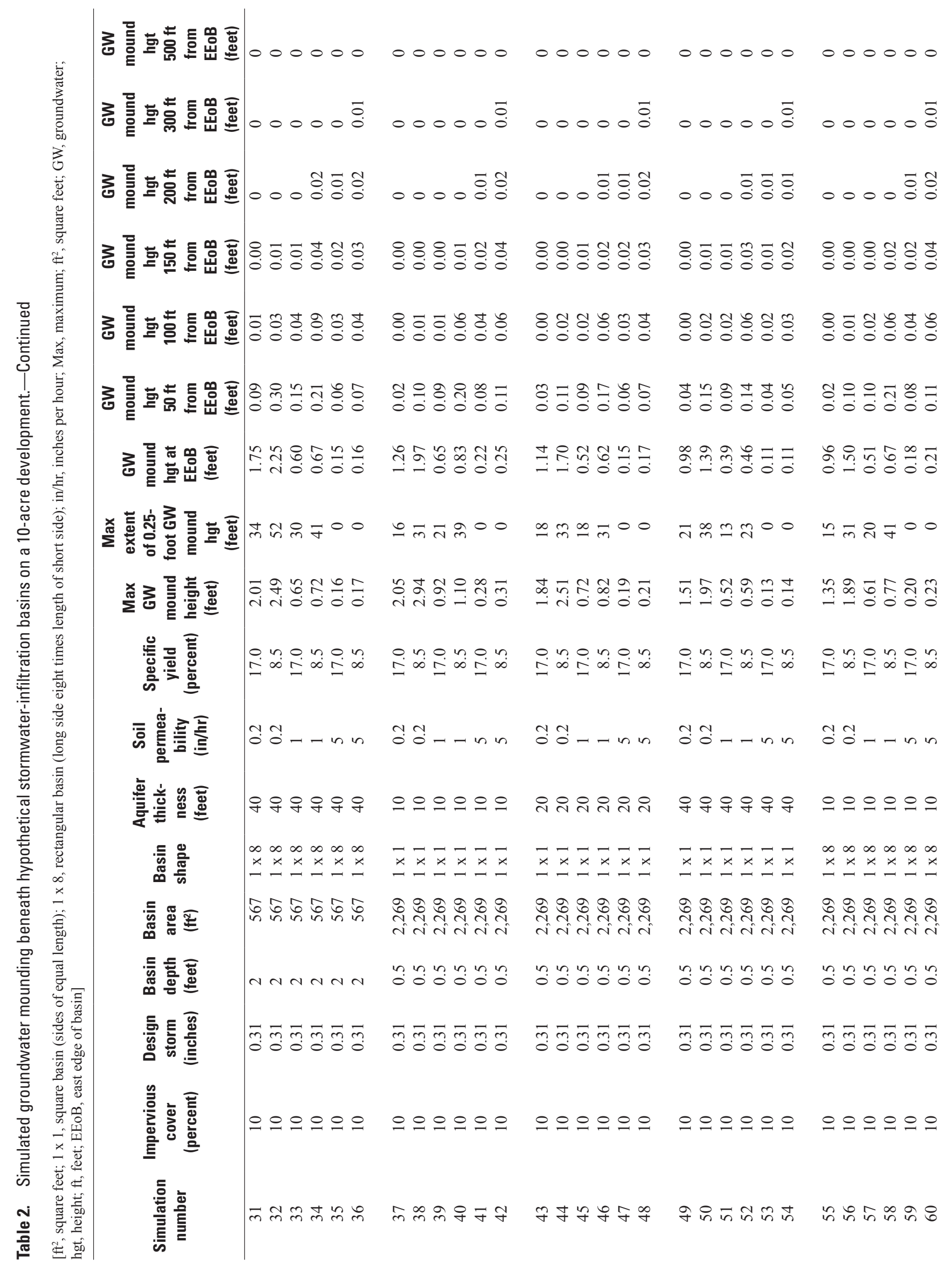




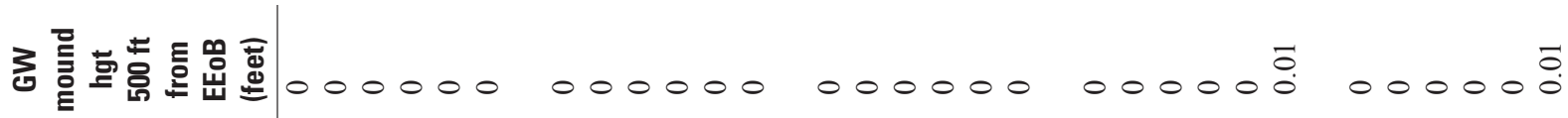

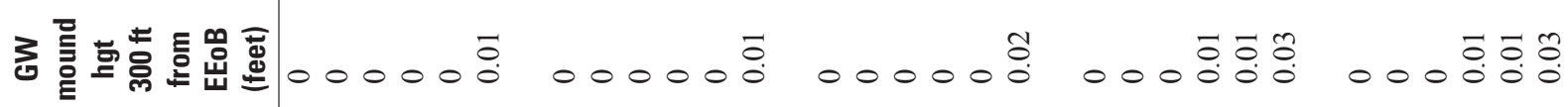

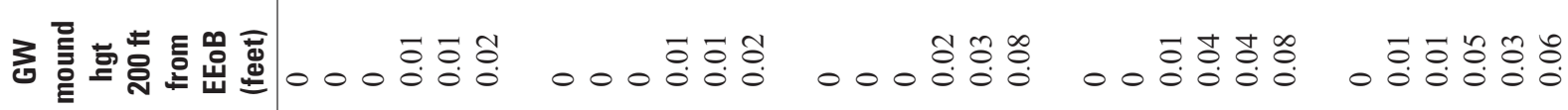

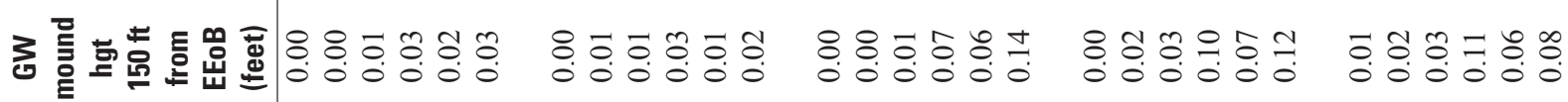

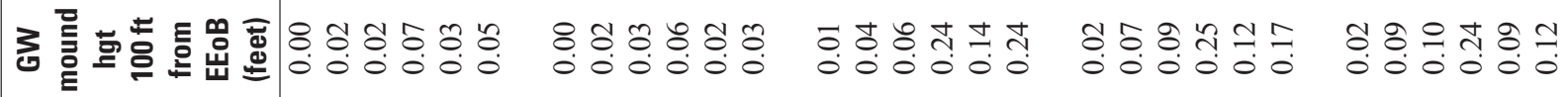

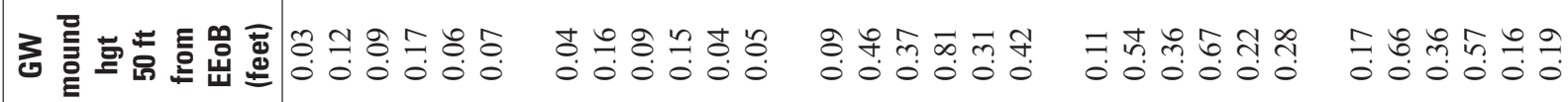

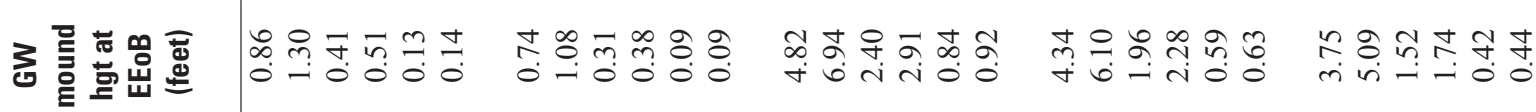

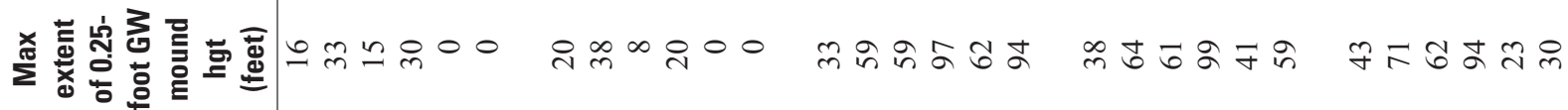

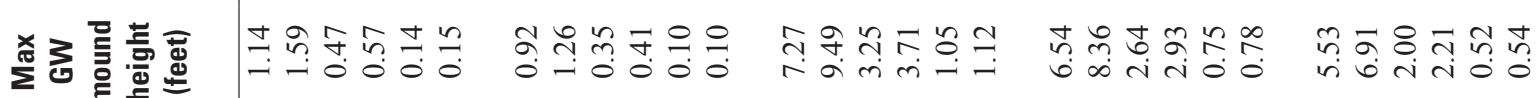

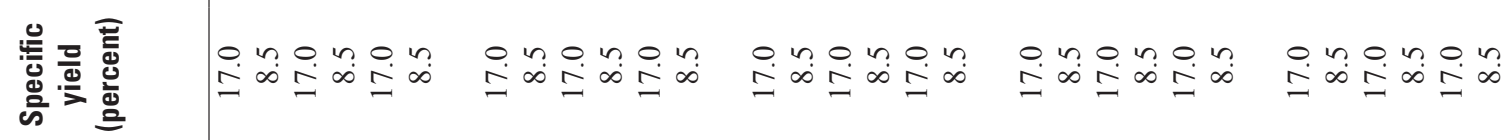

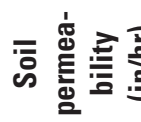

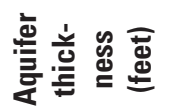
言兽

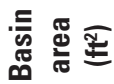
กै-

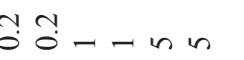
กุo ํ.

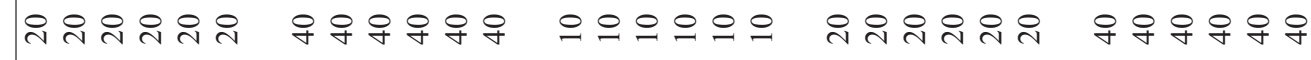
$\begin{array}{llllll}\infty & \infty & \infty & \infty & \infty & \infty \\ x & x & x & x & \times & x\end{array}$

$\infty \infty \infty \infty \infty \infty$

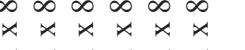

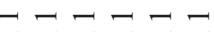

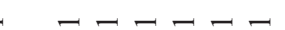

오 웅 웅 तี

के के

$x \times x-7$

$\neg-\neg-\neg-$ 跣

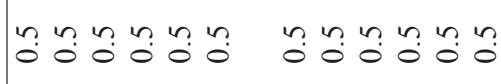
号 흉 言高离

$\bar{m} \bar{m} \bar{m}$

$\vec{m} \bar{m} \vec{m} \vec{m} \bar{m}$

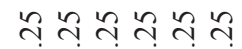

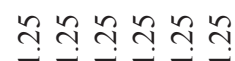

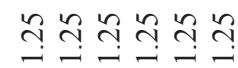
言竞焉

으으으으으으 으으으으으으 으으으으으으 으으으으으으 으으으으으으 


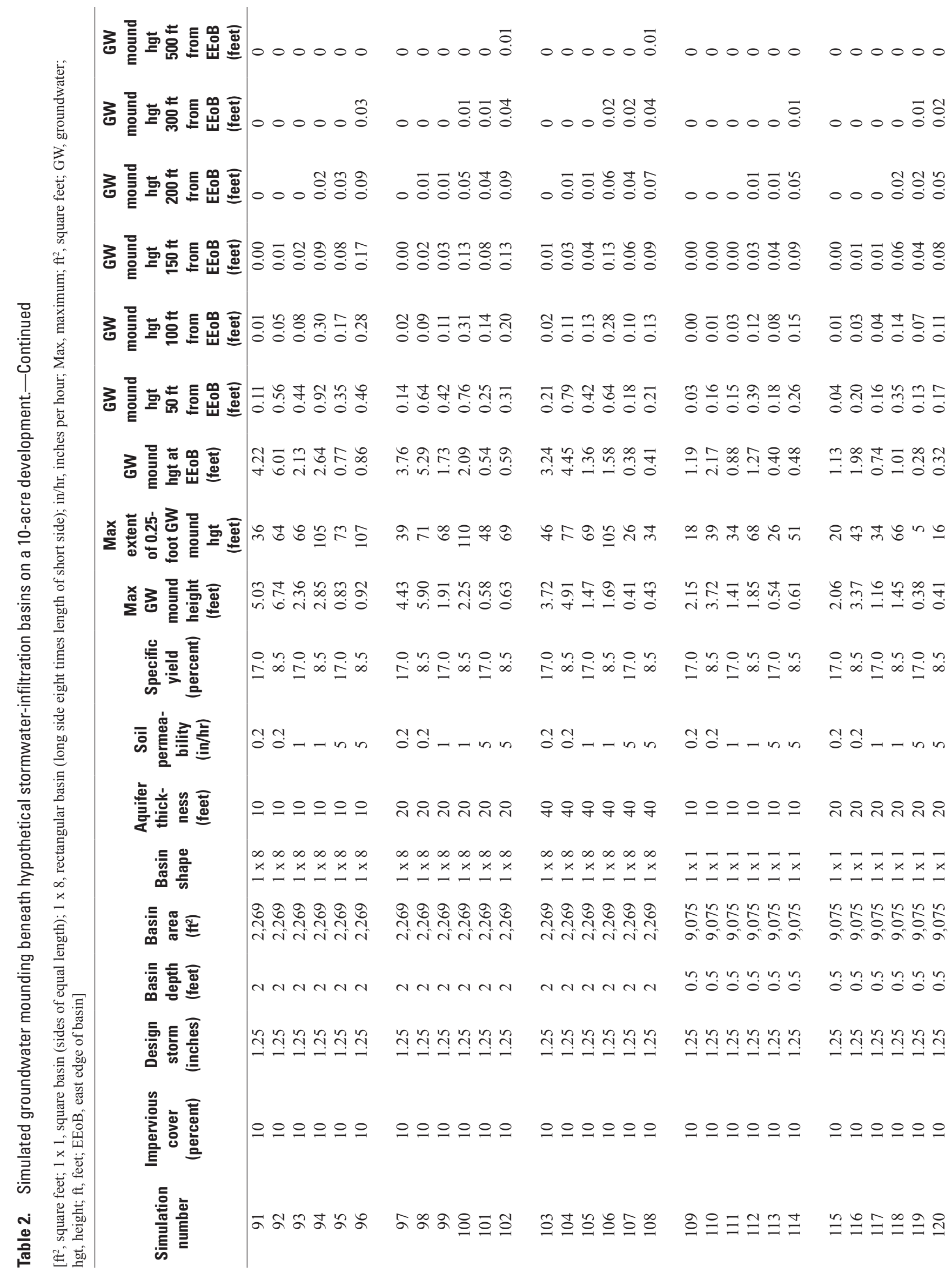




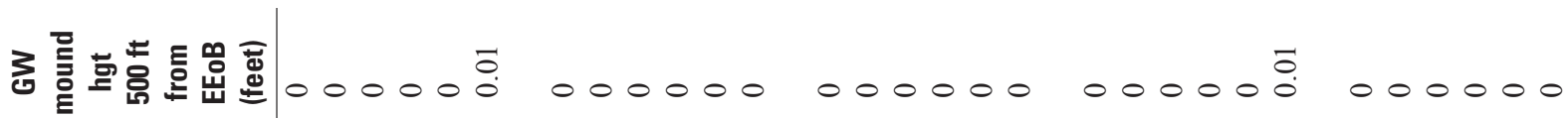

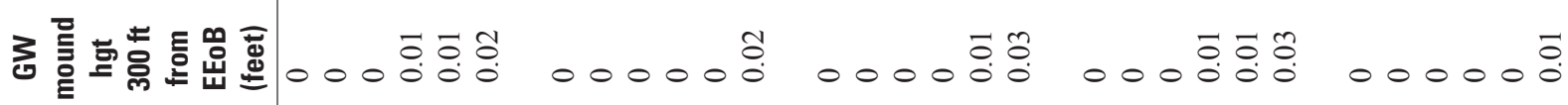

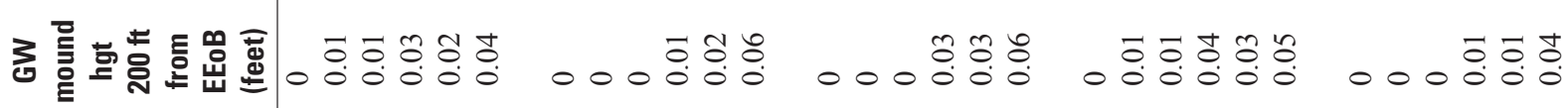

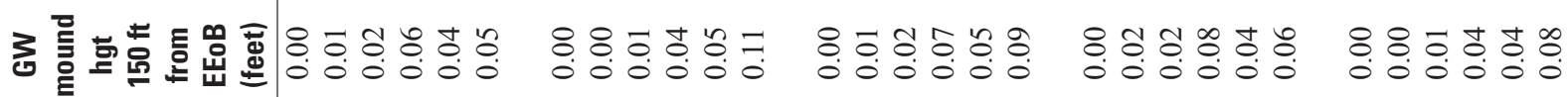

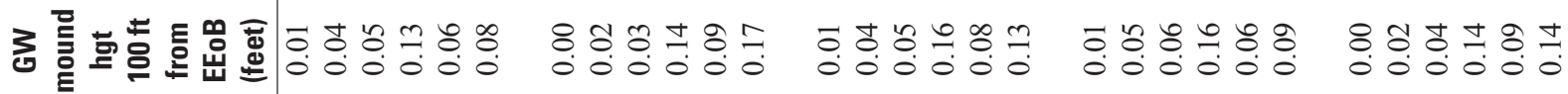

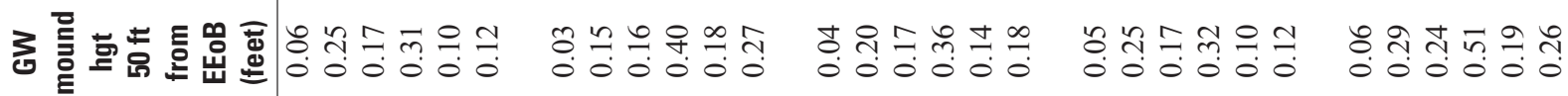

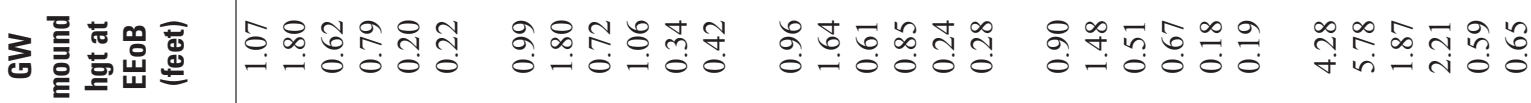

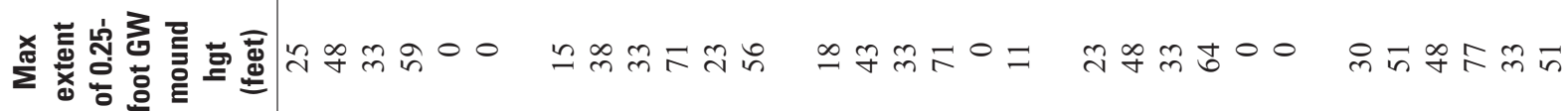

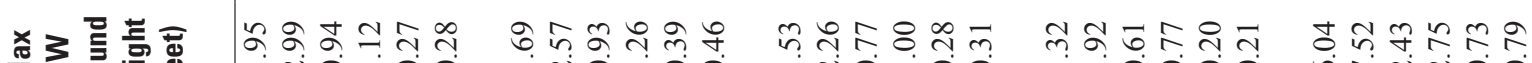

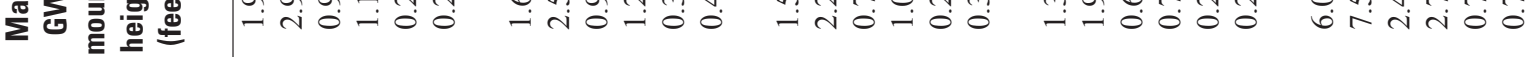

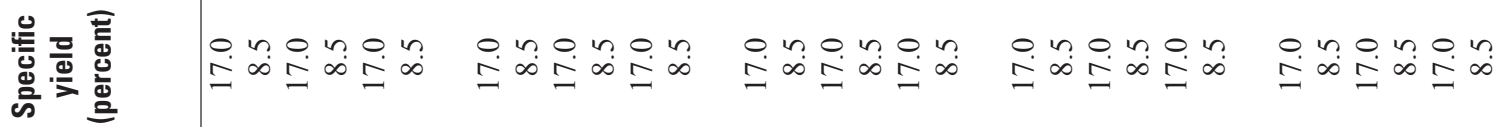

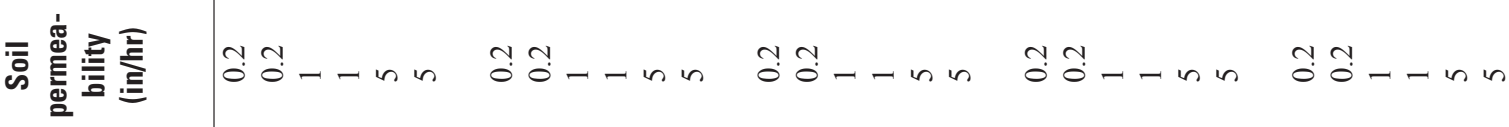

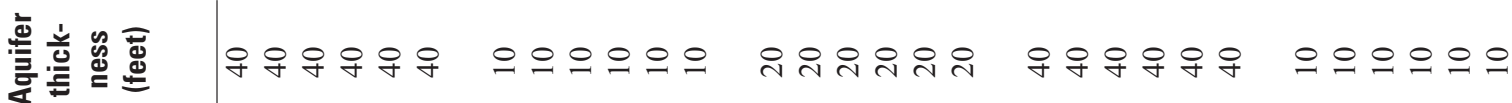

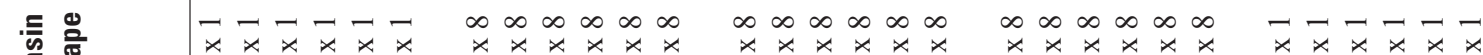
"⿹

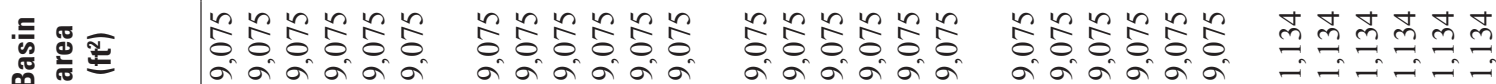

I
震 흥

衰

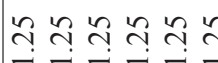

กุำ

กุำ

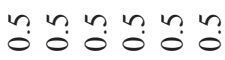

$\operatorname{NanN}$

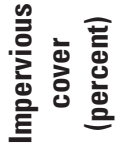

으으으으으으

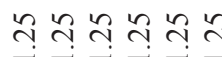

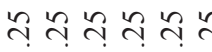

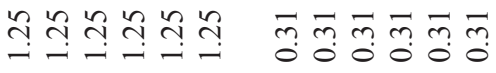




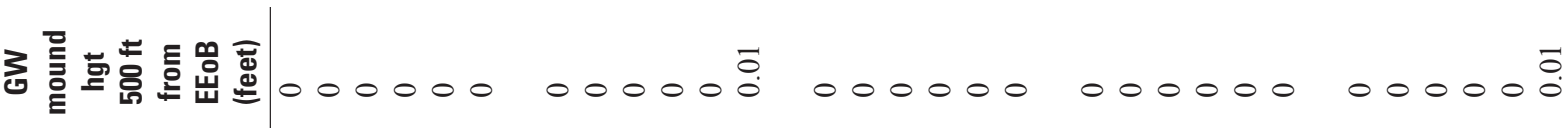

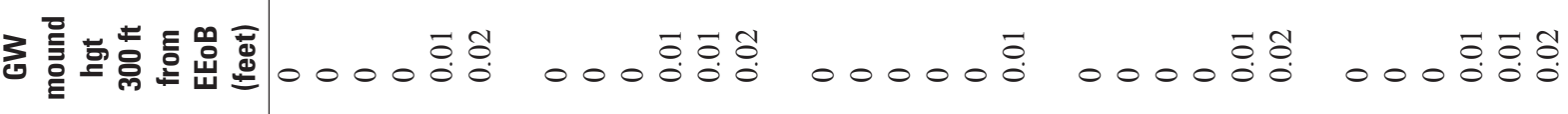

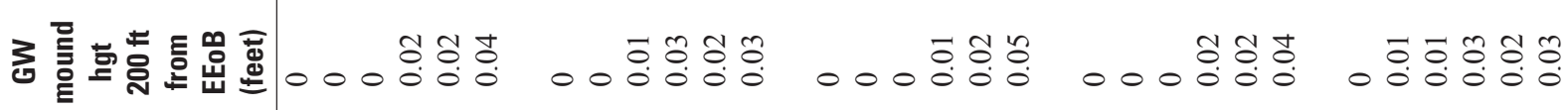

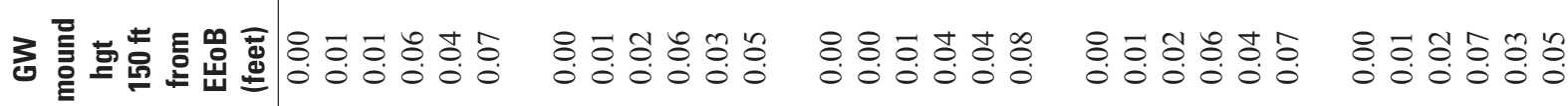

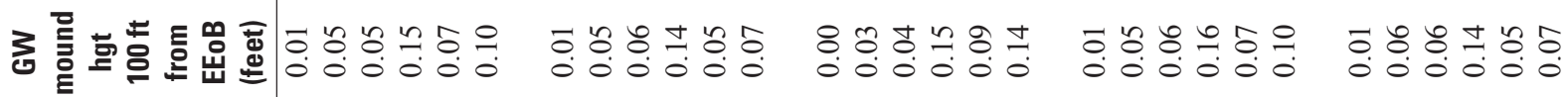

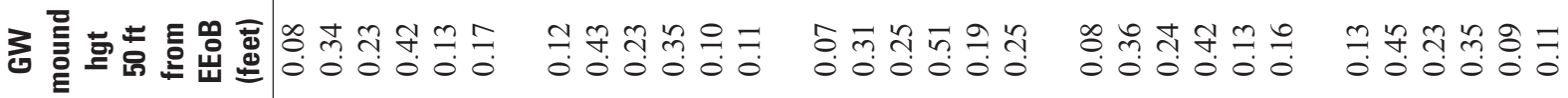

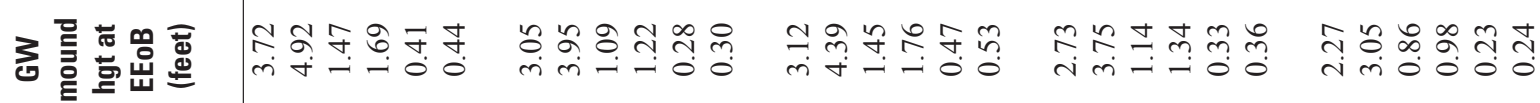

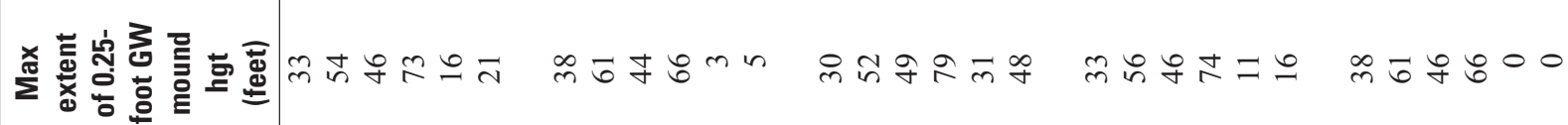

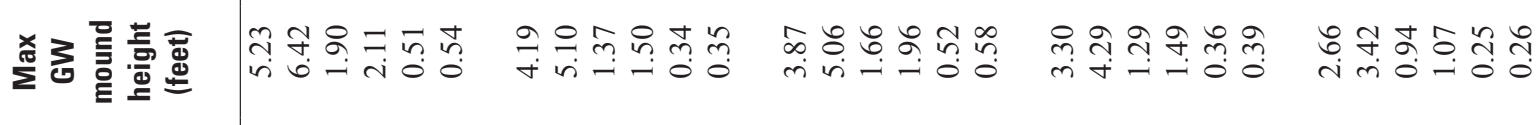
衷 क $\triangleq$

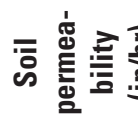

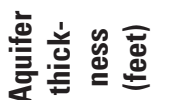

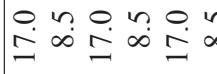

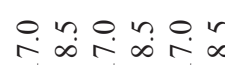

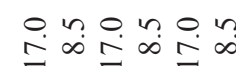

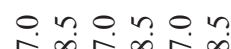

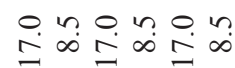

กุ

$\stackrel{0}{\pi}$

กุ่ กี่

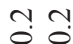

กุ่ กี่

กิ ำ ิํำ ิ

우우아의우

으으으으으우

유유유유

우아아우우우

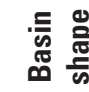

$\vec{x} \vec{x} \vec{x} \vec{x} \vec{x} \quad \vec{x} \vec{x} \vec{x} \vec{x} \vec{x} \vec{x}$

$\infty \infty \infty \infty \infty \infty \quad \infty \infty \infty \infty \infty \infty$

$\infty \infty \infty \infty \infty \infty$

$\infty \infty \infty \infty \infty \infty$

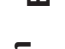

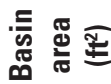

A+ +4

-

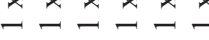

$\stackrel{x}{\sim} \underset{\sim}{-} \stackrel{x}{-} \stackrel{x}{-}$

$\stackrel{x}{\sim} \underset{\sim}{-} \stackrel{x}{-} \stackrel{x}{-}$

言 등

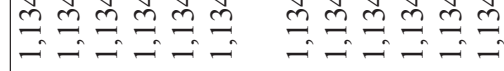

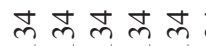

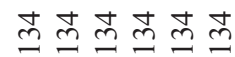

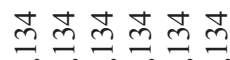

遌 흏

衰

$4 \sin 4$

N N N N

$\mathrm{N} N \mathrm{~N} N$

$\mathrm{NNNN}$

N N $N N$

$\bar{m} \vec{m} \bar{m} \vec{m}$

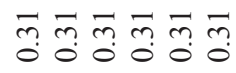

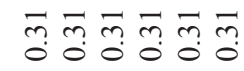

ज़ $\bar{m} \bar{m}$

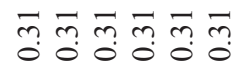

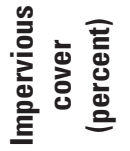

규ํํํํํำ

유유유유유

유유유유유

ิㅠํํํํำ

ิㅠํํㅠํㅠ 


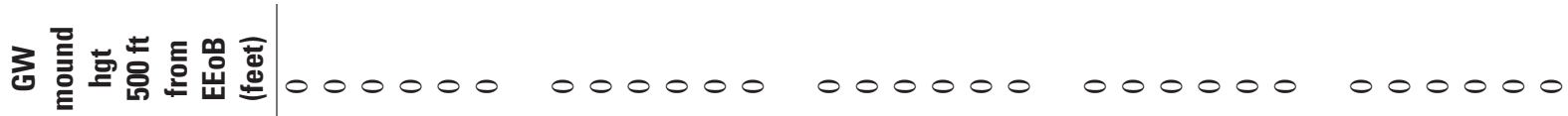

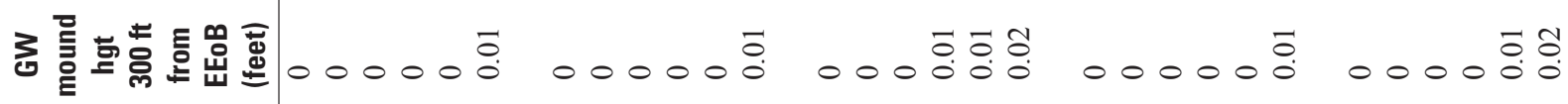

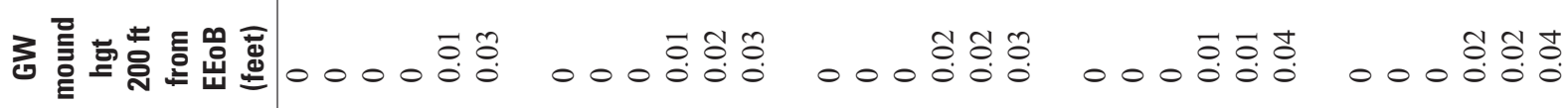

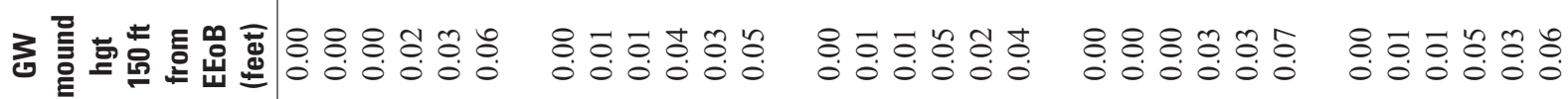

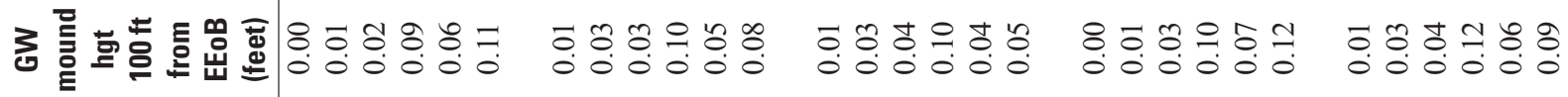

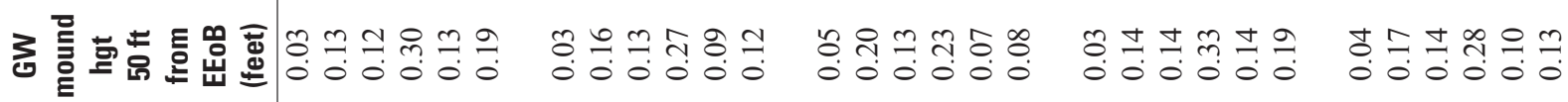
卷言苛出焉

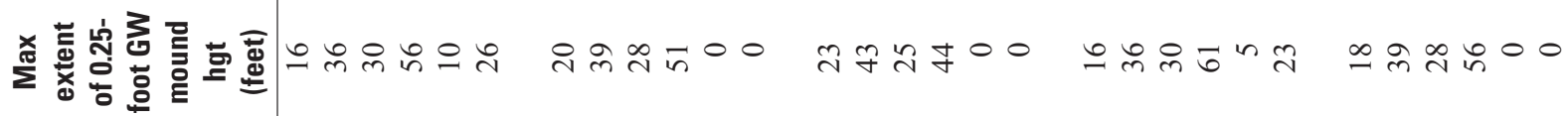

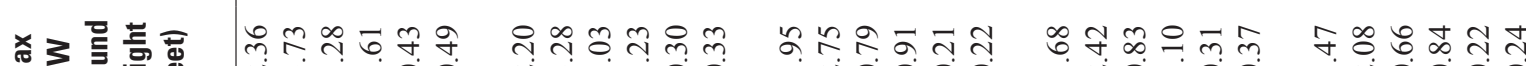

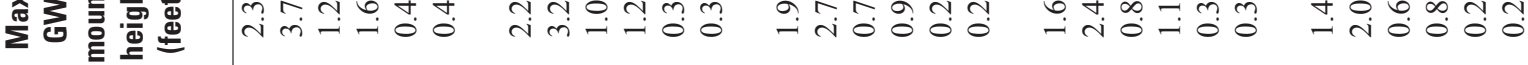
产 믈

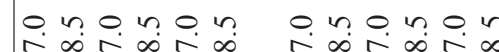

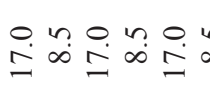

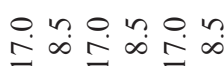

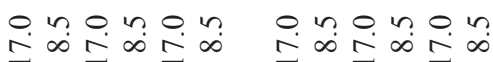

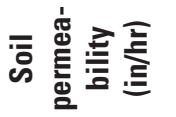
กับ ชี

กุก

กำ

กำ

กุด กี

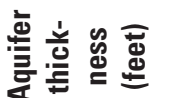

으으으으응 유유유유 우아아아와

으으으으으으

유유ำำ

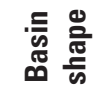

$\vec{x} \bar{x} \vec{x} \bar{x} \bar{x}$

$\vec{x} \bar{x} \vec{x} \bar{x}-$

$\vec{x} \vec{x} \bar{x}-\vec{x}$

$\infty \infty \infty \infty \infty \infty$

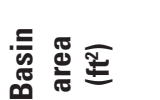

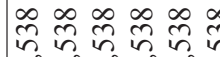

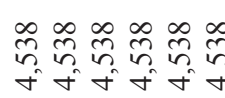

$\stackrel{x}{-} \underset{\sim}{ } \stackrel{x}{\sim} \stackrel{x}{-}$

$\stackrel{x}{x} \underline{x} \times \underset{x}{x}$

$\infty \infty \infty \infty \infty$

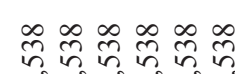

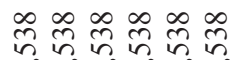
$\stackrel{x}{\sim} \underset{\sim}{-} \stackrel{x}{-} \underset{\sim}{-}$ 恶 竞

กุด

กุำกำกำ

ำ

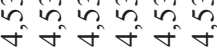

$\begin{array}{llll}\infty & \infty & \infty & \infty \\ n & \infty & \infty & \infty \\ n & n & n & n \\ n & n & n\end{array}$

言

$\vec{m} \vec{m} \vec{m} \vec{m}$

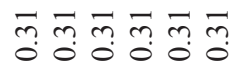

$\vec{m} \bar{m} \vec{m}$

กุำกำ

กำกำกำ

总高

ํํํำ ㅇํ

ㅇํํํํํํำ

중ำ 쥬

ํํ유ㅈㅠㅠㅠ

유유유유 


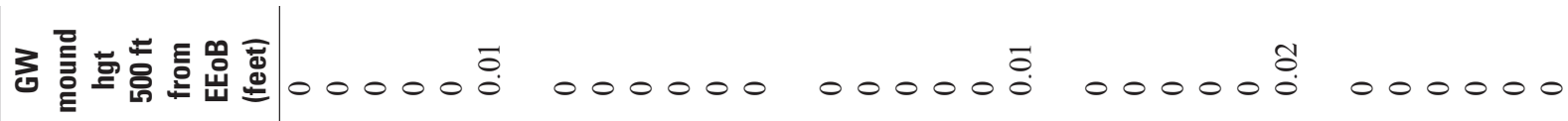

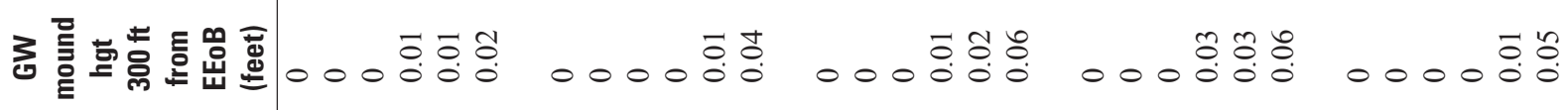

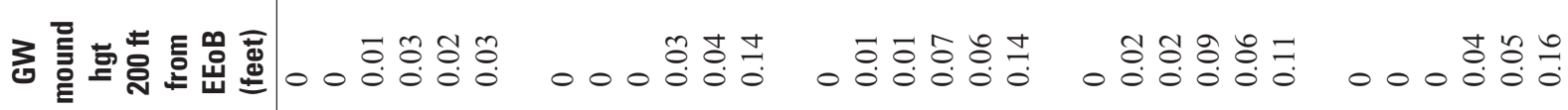

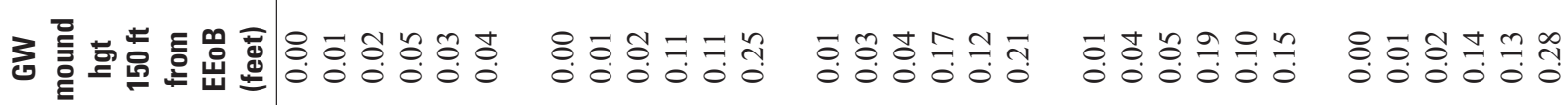

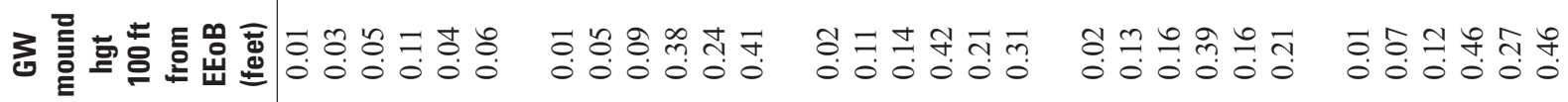

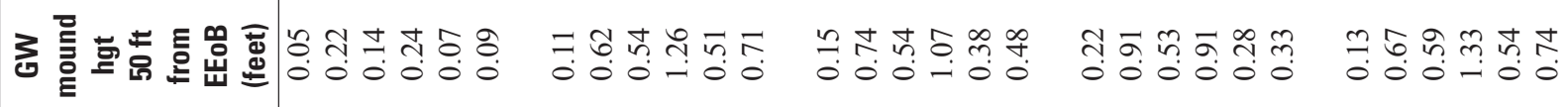

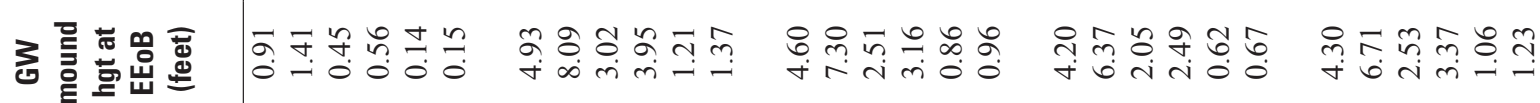

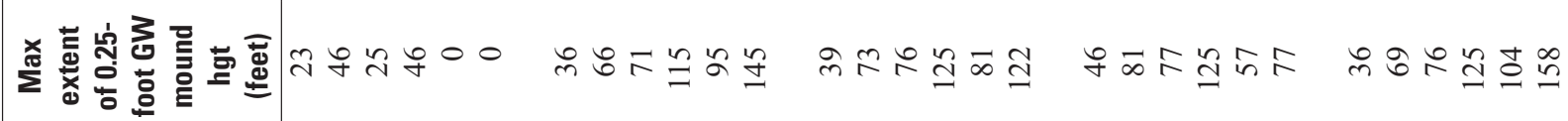

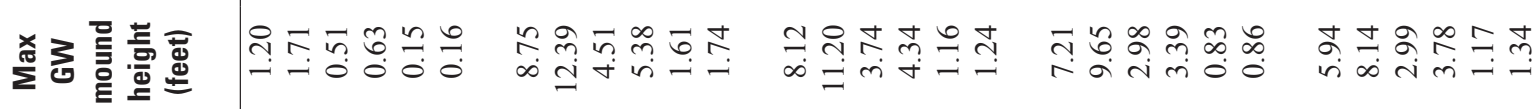

釆

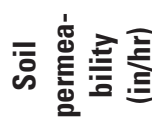

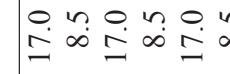

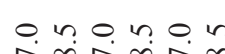

o. no no. n

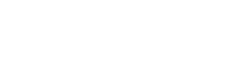

in o in on

$=\infty$

$=\infty \pm \infty$

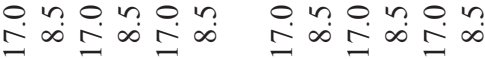

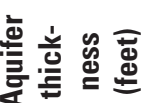

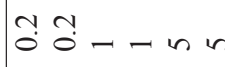

กุบ

กุบ กับ

กุ

$\stackrel{0}{\pi}$

in

高总

if $q$ q $q$ q $q$

으으으으으

กิ กิ กิ ำำ

우우우우우우

으으으으으으

言恋恋

$\begin{array}{llllll}\infty & \infty & \infty & \infty & \infty & \infty \\ x & x & x & x & x & x\end{array}$

$\vec{x}-\vec{x}-\vec{x}+$

$\stackrel{x}{\sim} \underset{\sim}{-} \stackrel{x}{-} \stackrel{x}{-}$

$\vec{x}-\vec{x}-\vec{x}$

$\vec{x} \bar{x} \vec{x} \bar{x} \bar{x}$

$\infty \infty \infty \infty \infty \infty$

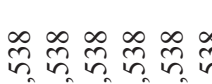

$\infty \sum_{n}^{\infty} \sum_{n}^{\infty} \sum_{n}^{\infty} \sum_{n}^{\infty}$

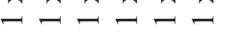

$\stackrel{x}{-} \stackrel{x}{-} \stackrel{x}{\sim} \stackrel{x}{-}$

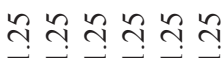

ํํํํํํํํํ 


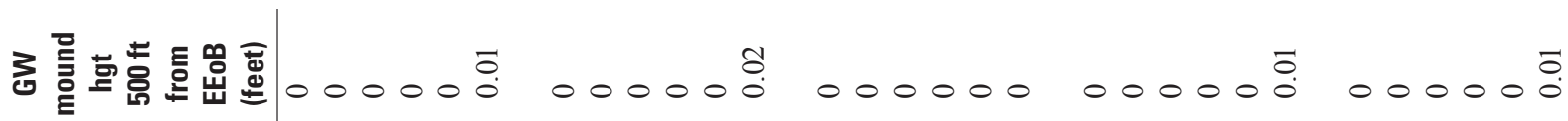

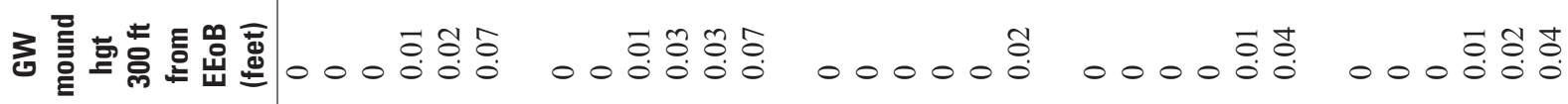

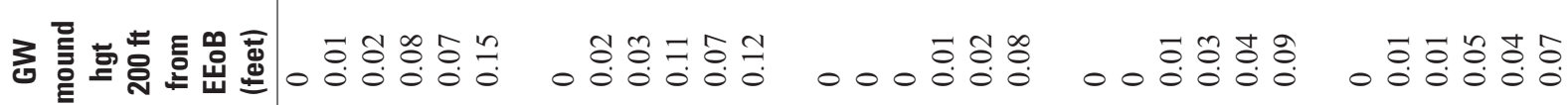

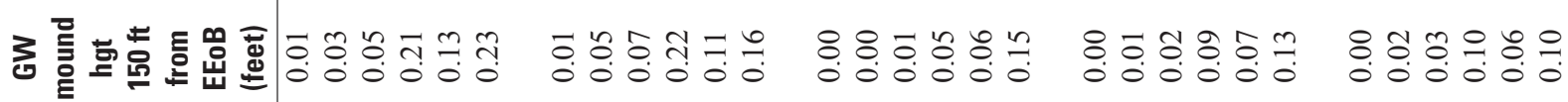

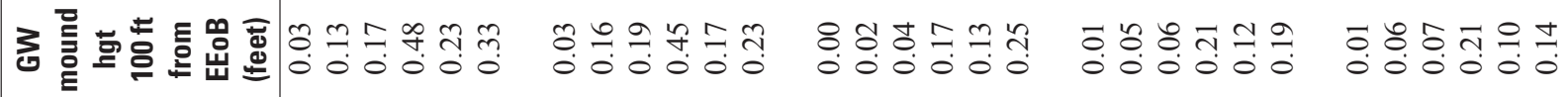

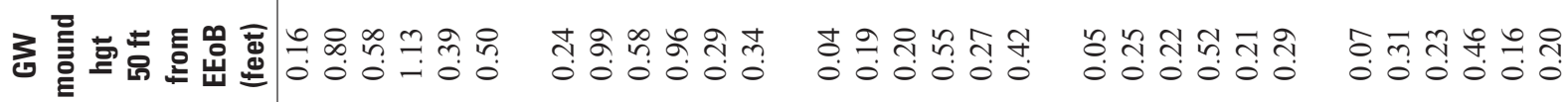

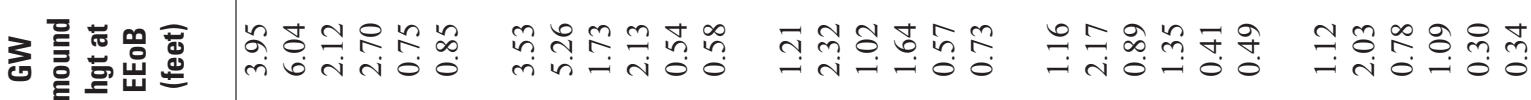

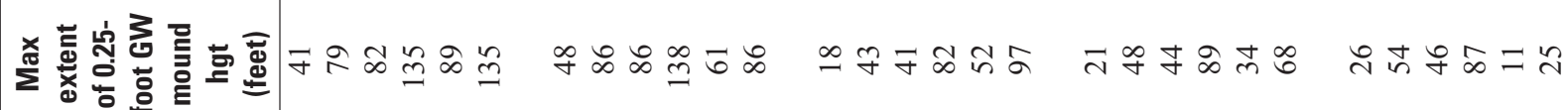

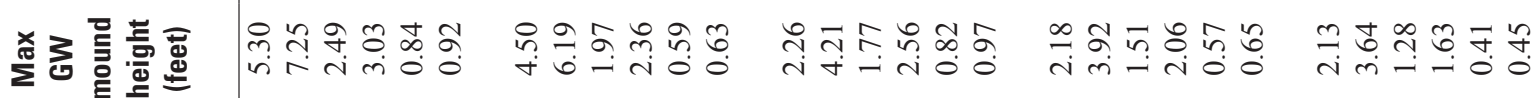

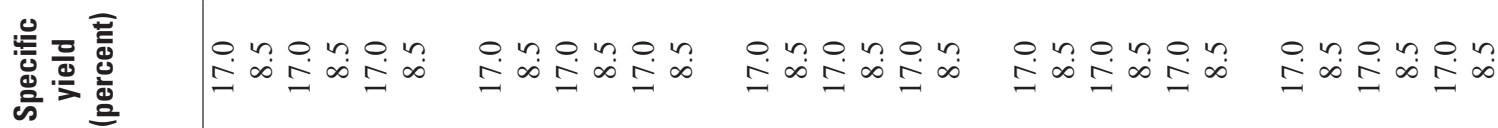

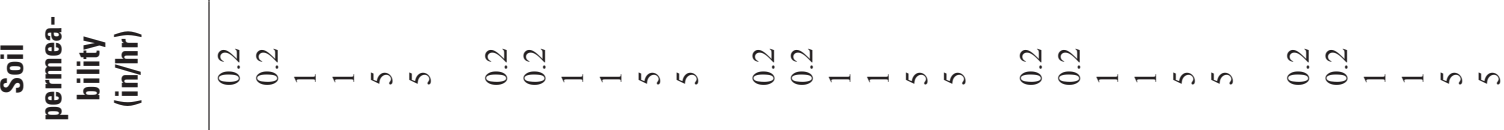

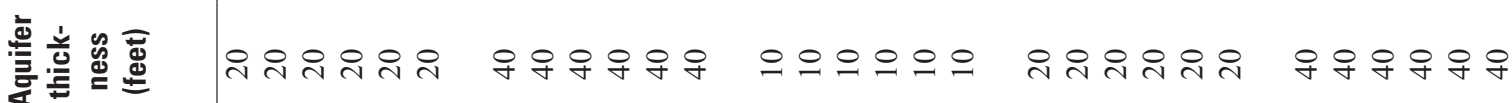

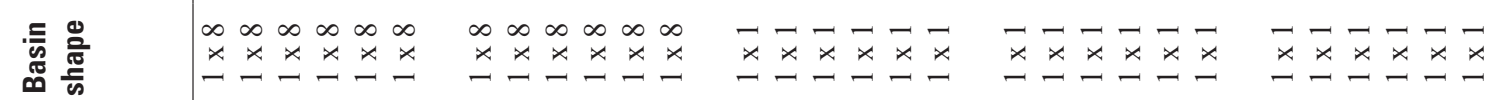

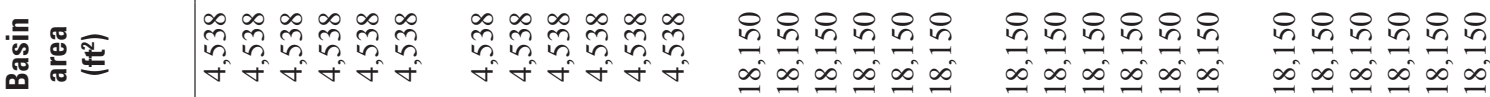

言恶

产

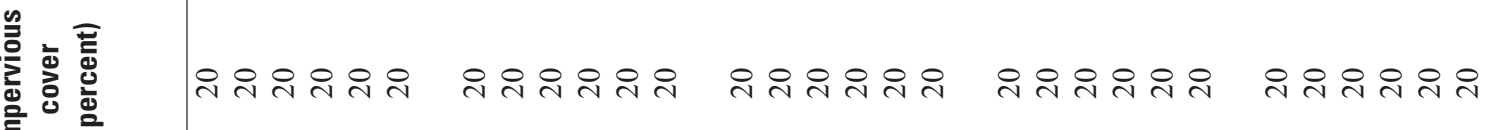

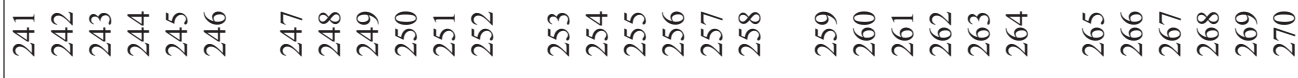




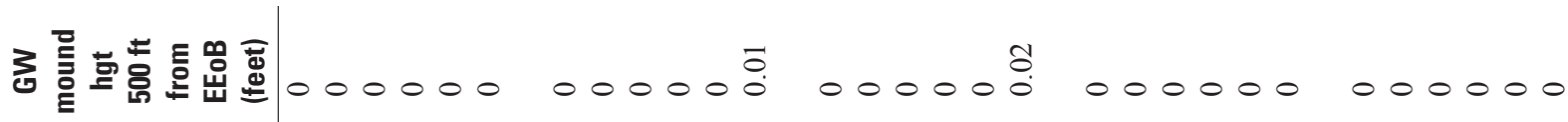

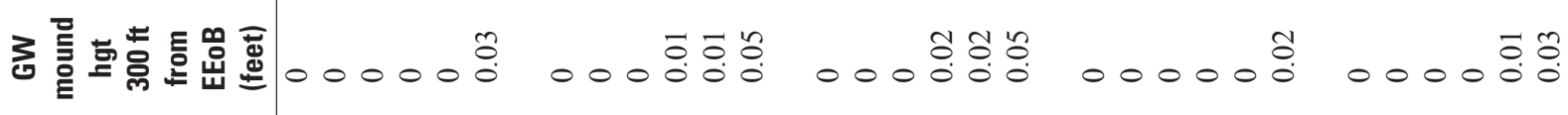

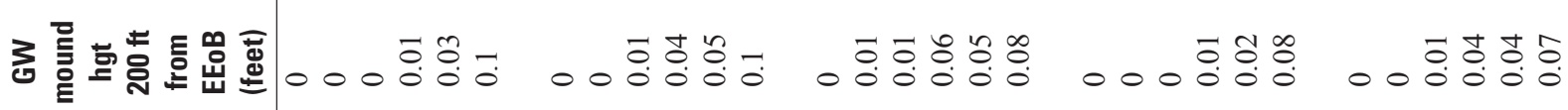

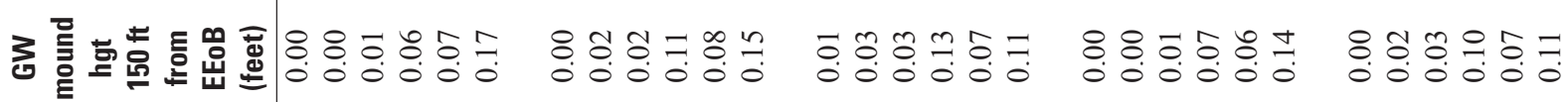

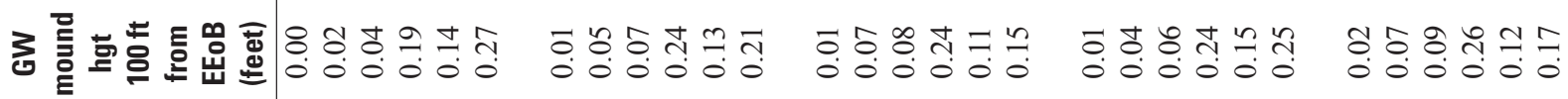

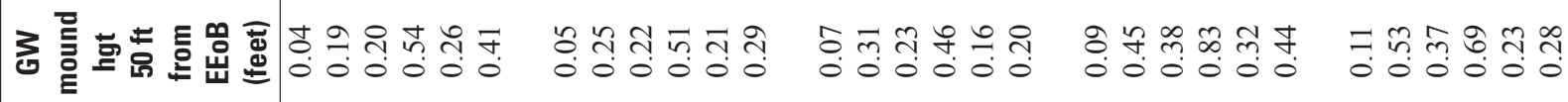

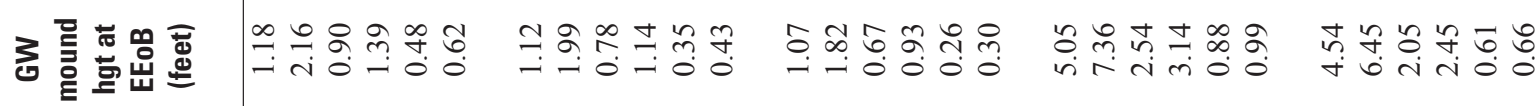

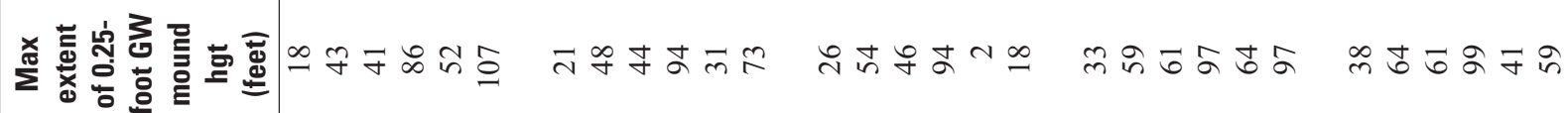

×言毒

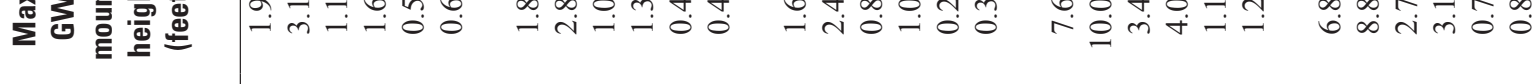

㝘

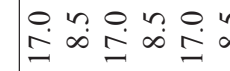

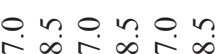

요요요요. 요

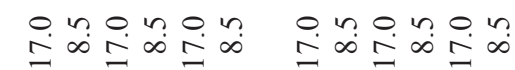

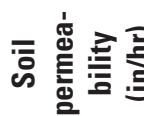

产竞总总

言

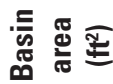

กู่

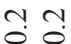

กุ่

ำ

กับ กุ่

$\sin 0$

으으으으으오

유유ํำ 구

아아아앙의

으으으으으으

유유유유ำ

$\infty \infty \infty \infty \infty \infty$

$\times \times \times \times \times \times$

$\infty \infty \infty \infty \infty \infty$

$\infty \infty \infty \infty \infty \infty$

$\stackrel{x}{\sim} \stackrel{x}{-} \underset{\sim}{-} \underline{\sim}$

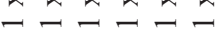

$x \not x \star x x x$

$\vec{x}-\vec{x}-\vec{x}$

$\stackrel{x}{\sim} \underset{x}{-} \stackrel{x}{-} \stackrel{x}{-}$

$\vec{x}-\vec{x}-\vec{x}$

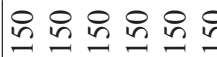

는으는은

은으는 은요

के

-1 - - -

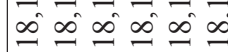

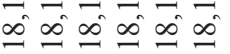

$\infty$ - $\infty^{0} \infty \infty^{\circ}$

तै तैत्तत्रतै

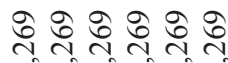

言 흥

กุำ

กำ

กุำ

衰

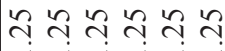

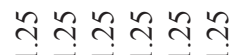

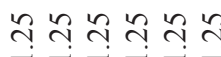

$\vec{m} \bar{m} \vec{m} \bar{m}$

$\bar{m} \bar{m} \bar{m} \bar{m} \bar{m} \overline{0}$

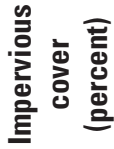

유유ํํํำ

ํㅠ유융ํ

ิㅠํํํํํำ

우앙아아왕

우아아아우우

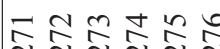

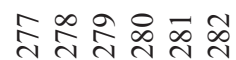

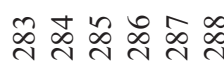

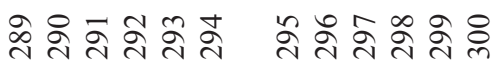




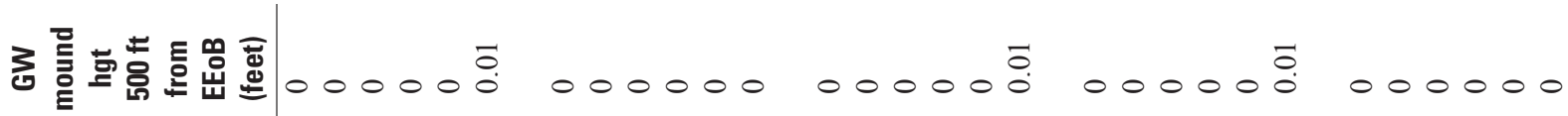

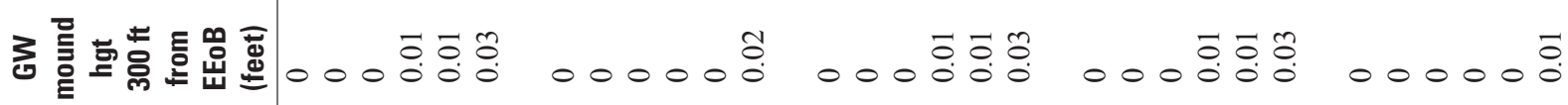

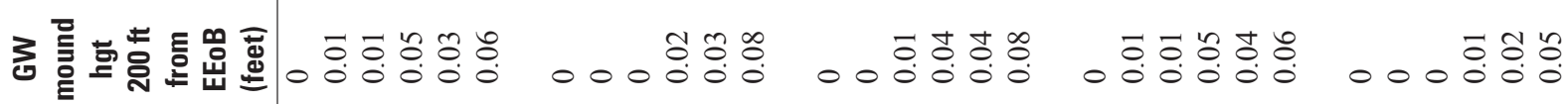

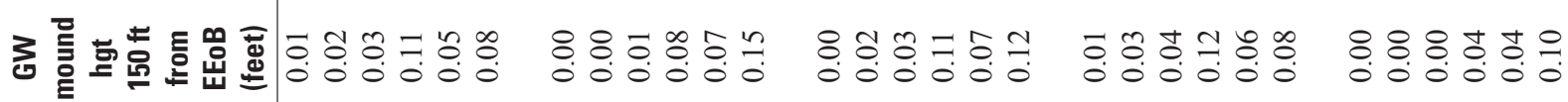

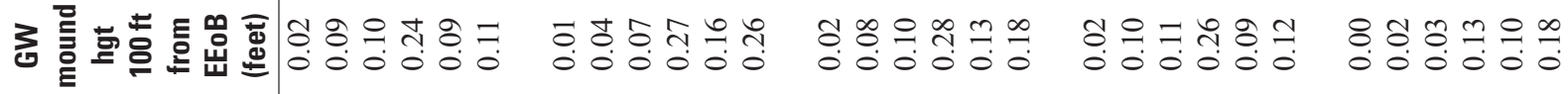

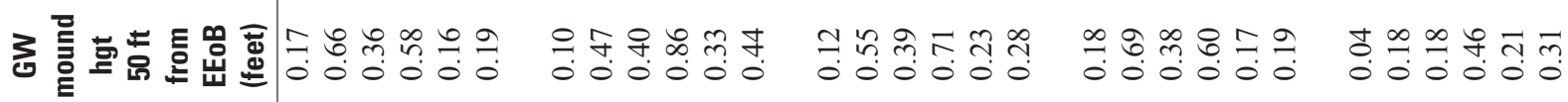

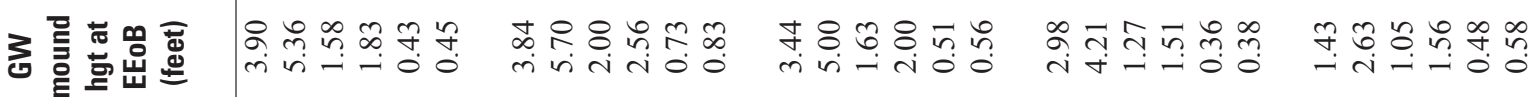

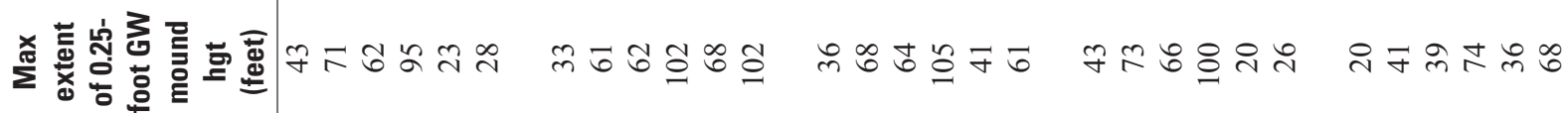

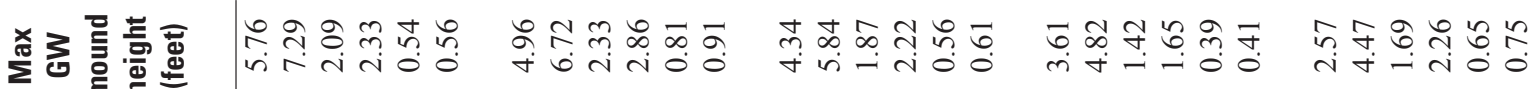

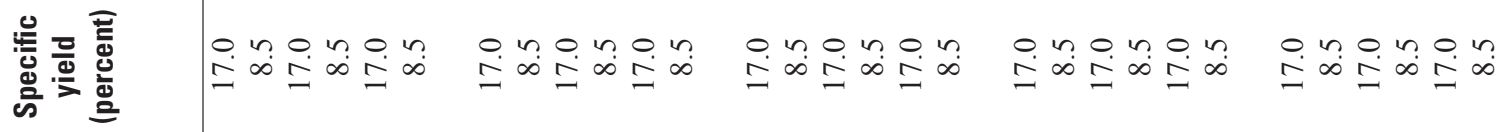

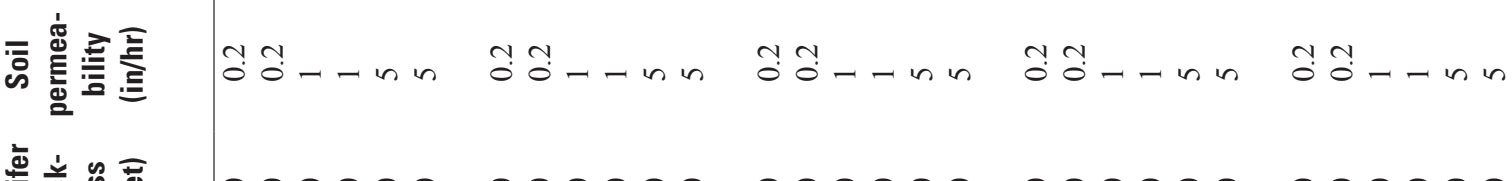

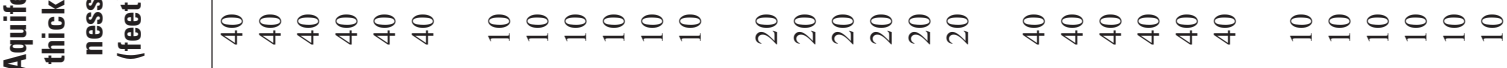

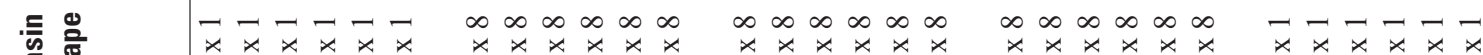

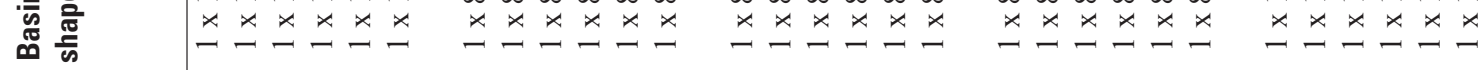

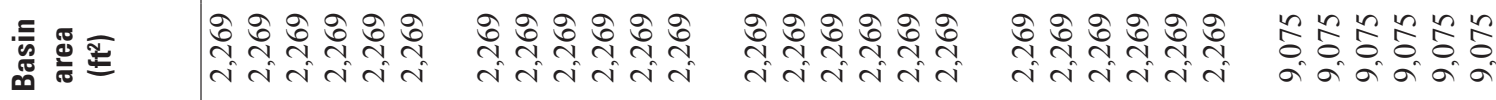

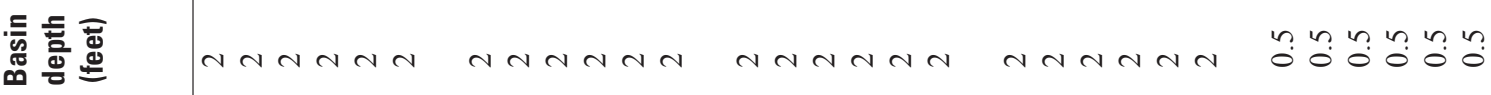

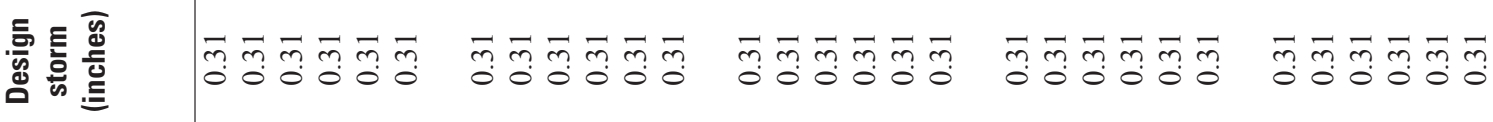

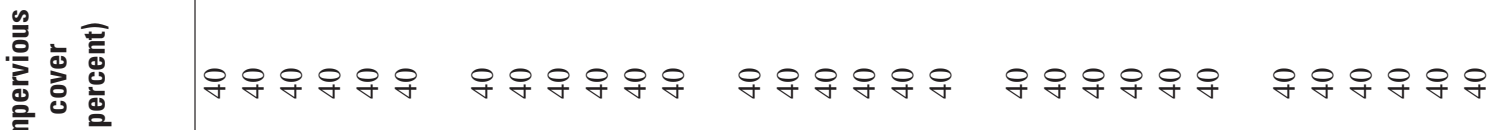

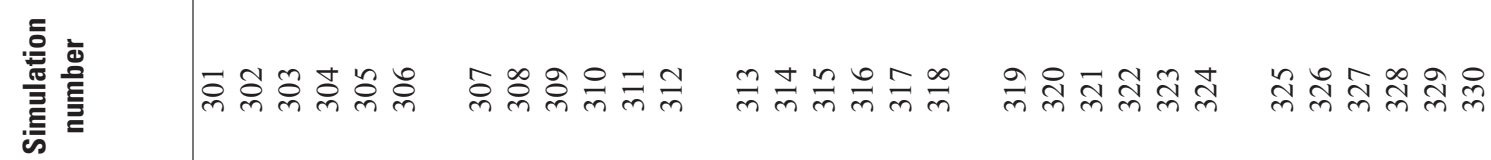




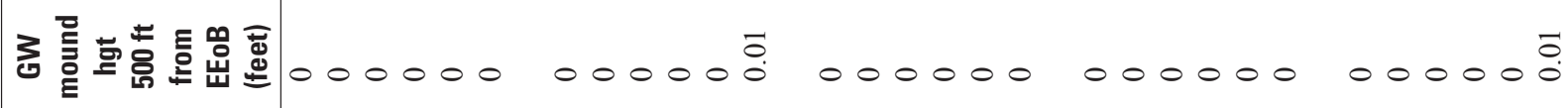

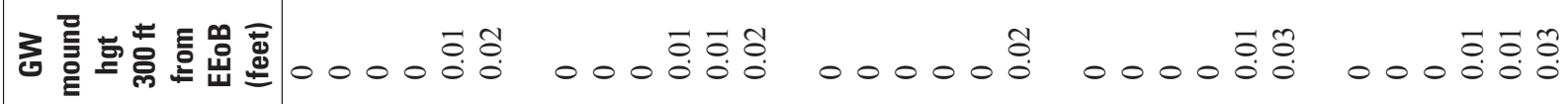

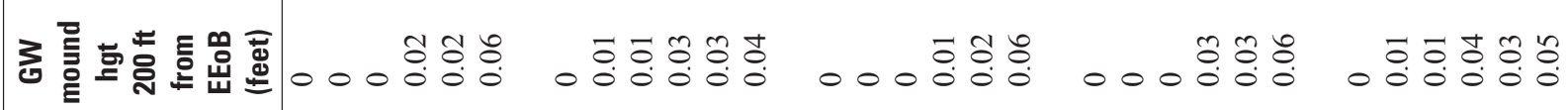

उ

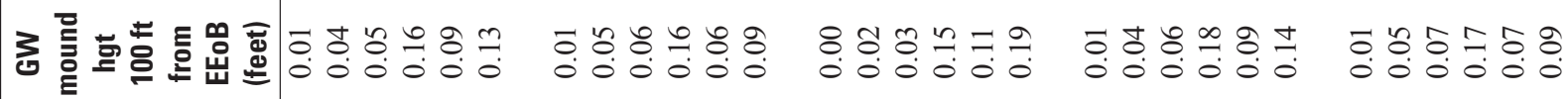

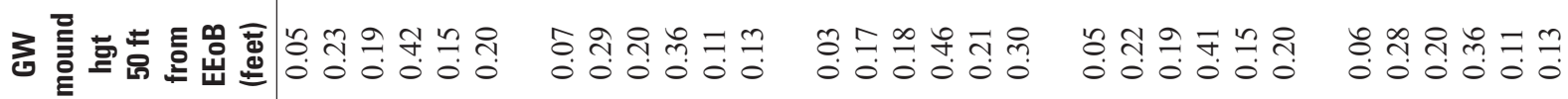

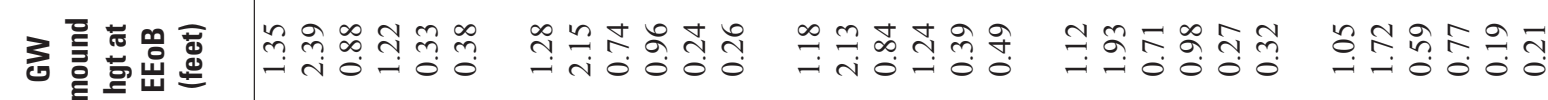

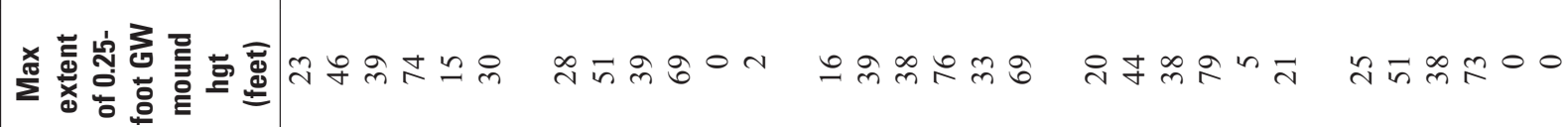

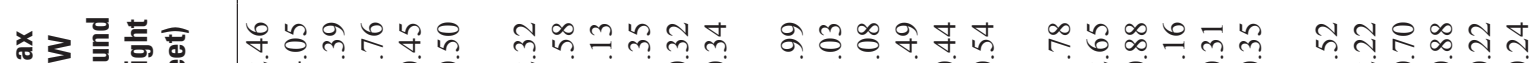

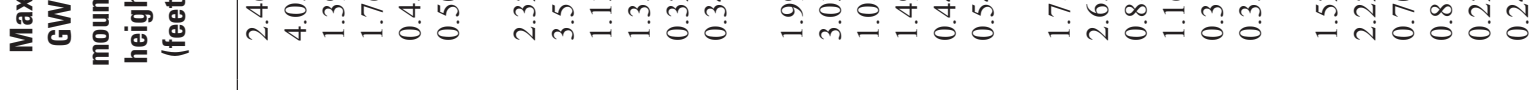

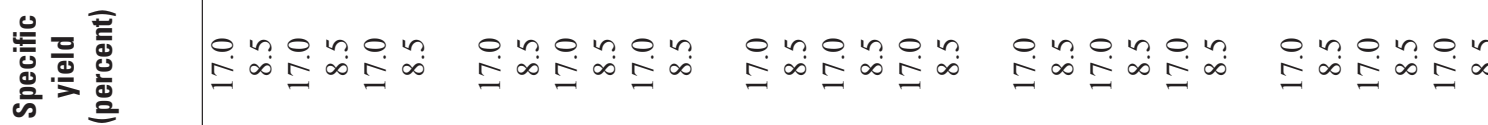
की 容离离

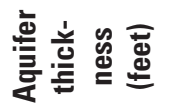

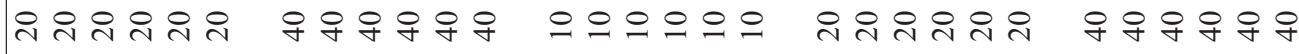

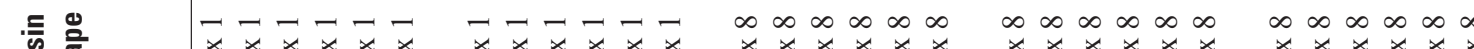

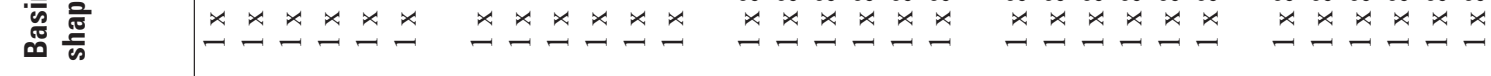

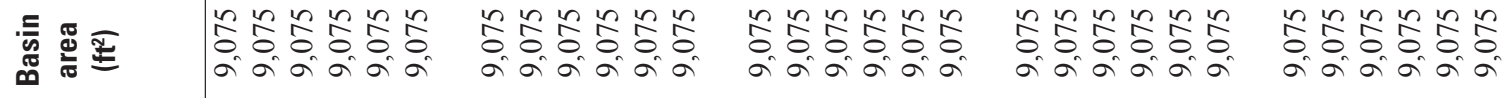

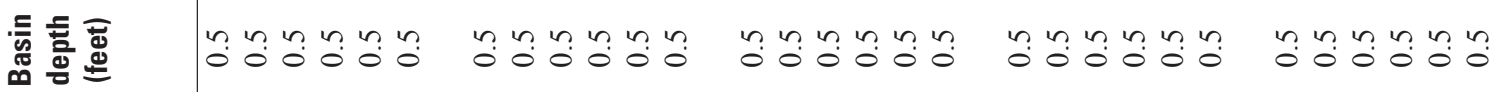

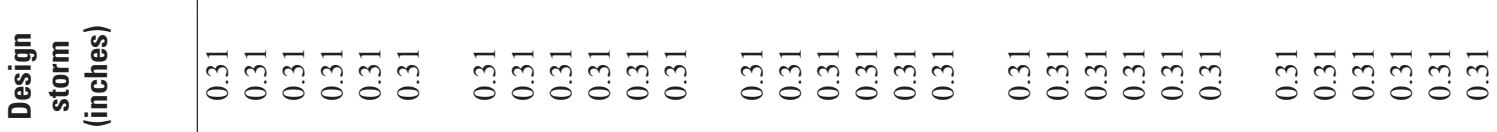

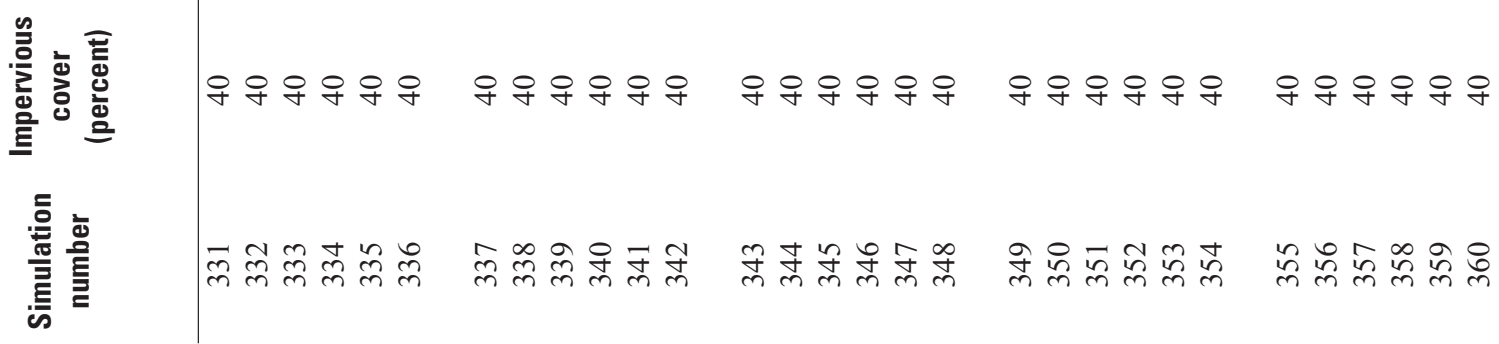




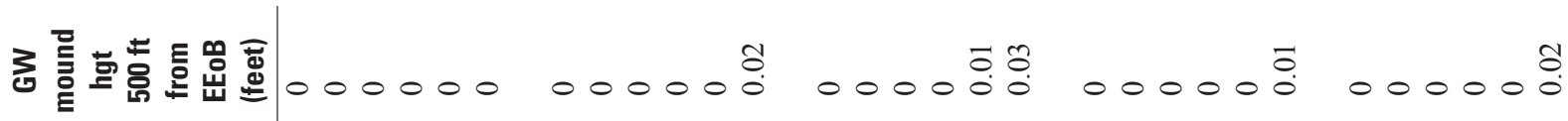

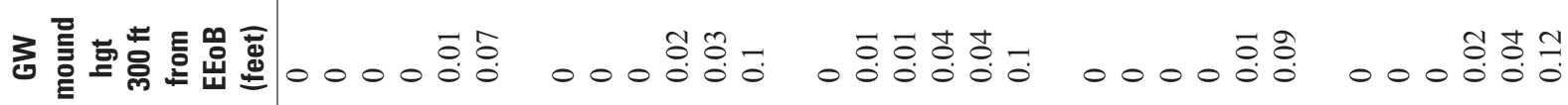

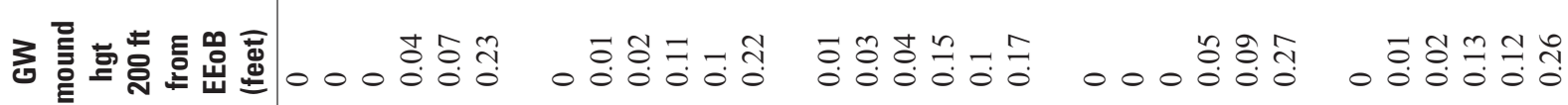

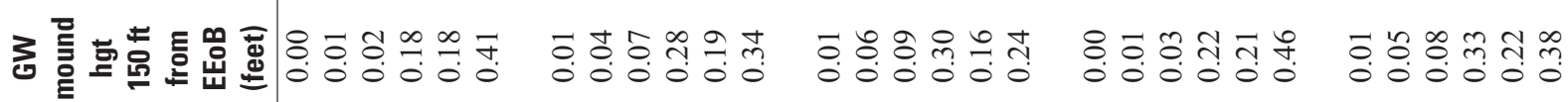

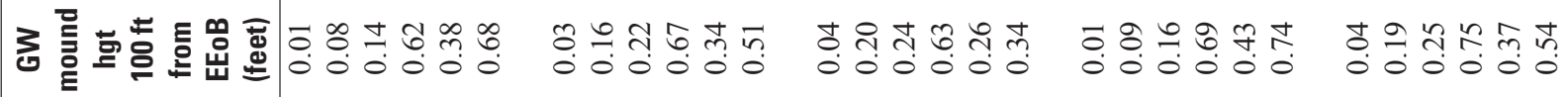

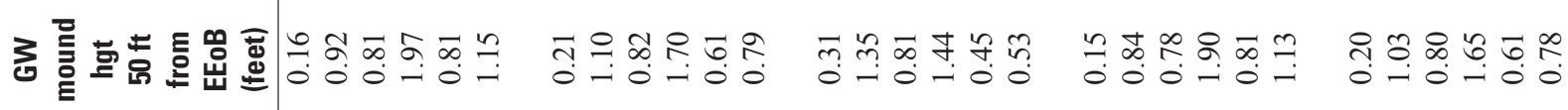

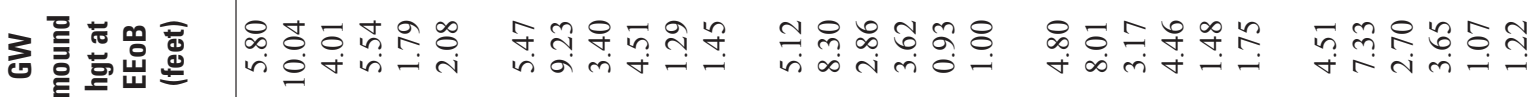

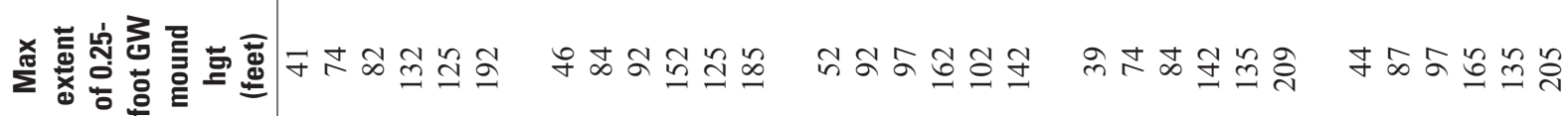

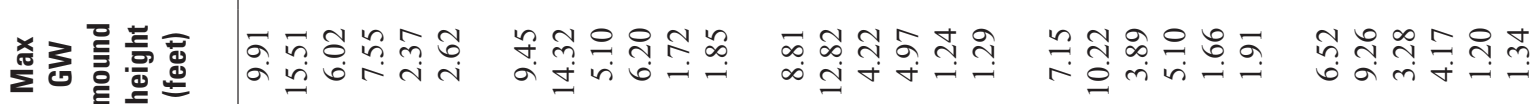

尤

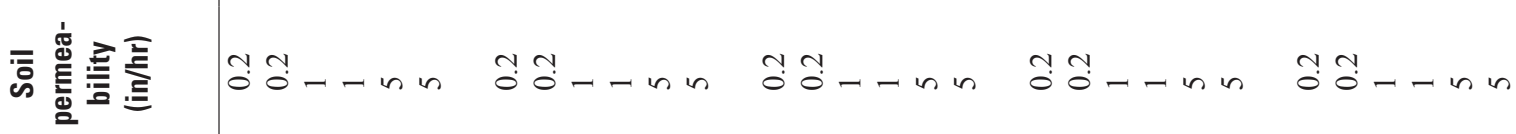

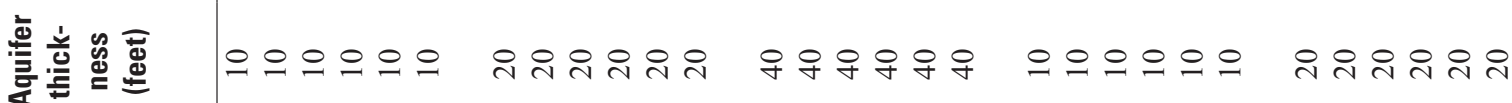

$=0-\neg-\neg-\neg-\neg-\neg-\neg-\neg \infty \infty \infty \infty \infty \quad \infty \infty \infty \infty \infty \infty$

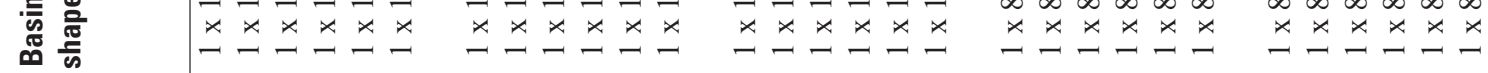

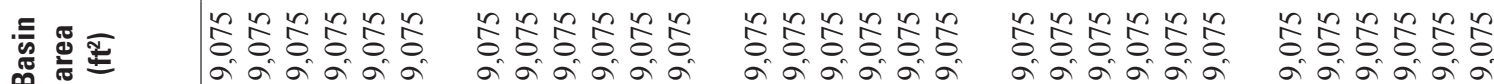

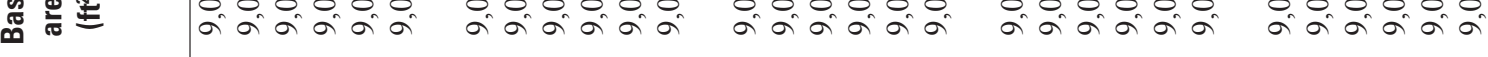

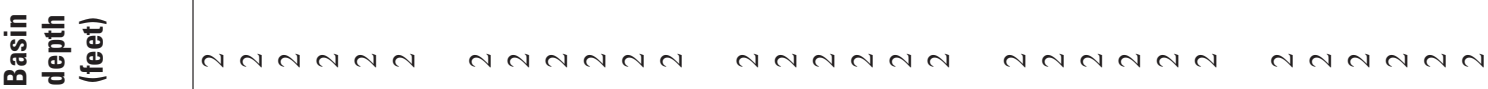

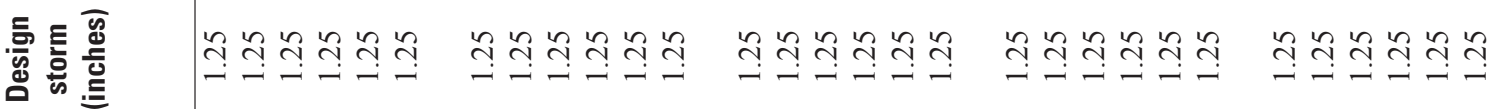

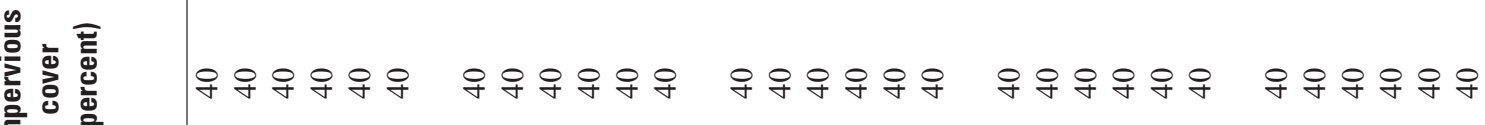

竞离 


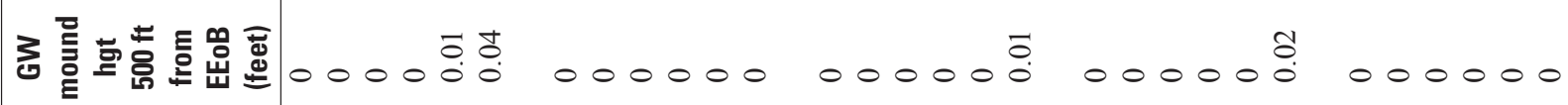

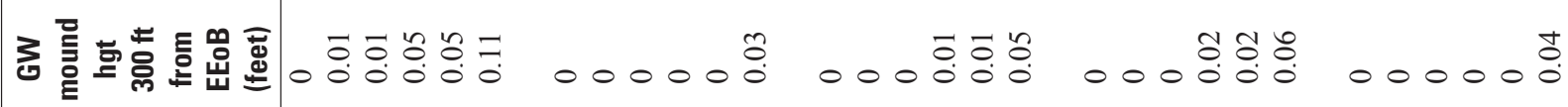

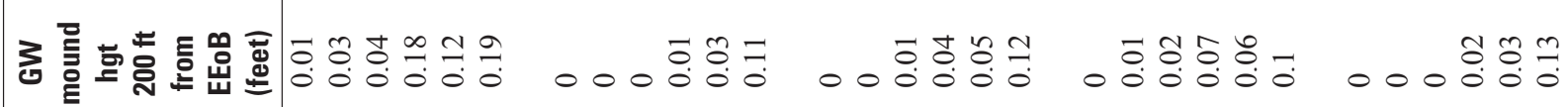

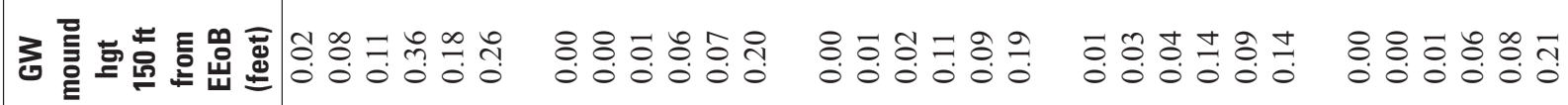

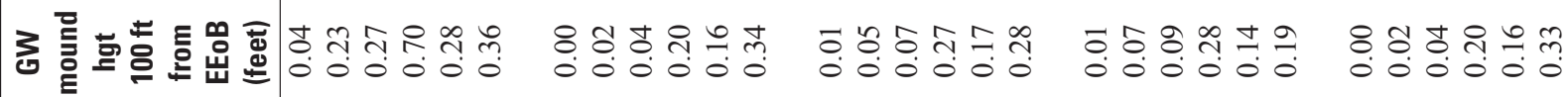

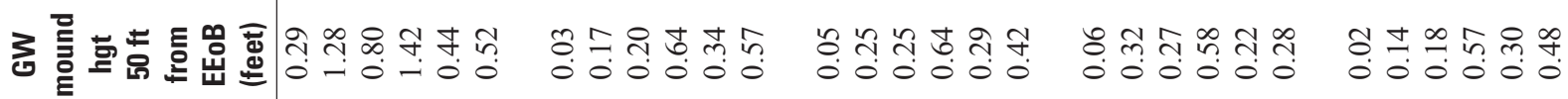

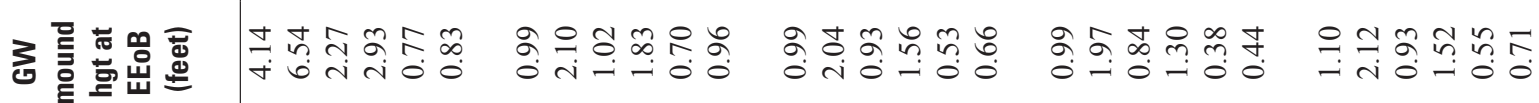

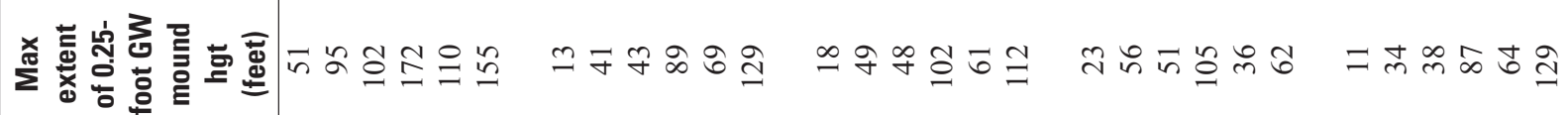

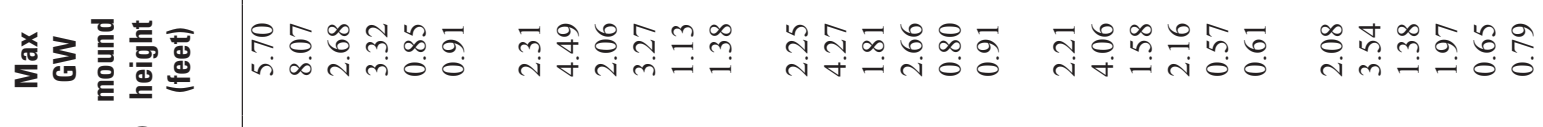

峞

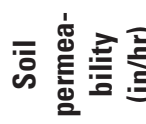

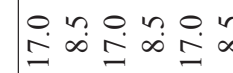

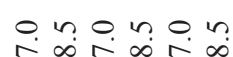

요요요요 응

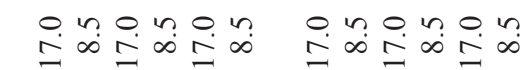

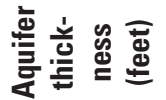

กุด ชี่-

กุบ

กุบ ำ

กุ

กั่

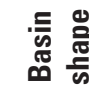

우우우워워우

으으으으으으

กิ กิ กิ ำำ

우아아우아우

으으으으으으

言胥恋

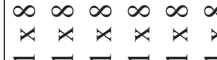

$\vec{x} \vec{x} \vec{x}-\vec{x}$

$\underset{x}{x} \stackrel{x}{-} \stackrel{x}{-}$

$\vec{x} \nabla-\vec{x}+\vec{x}$

$\neg-\neg-\neg-$

$\infty \infty \infty \infty \infty \infty$

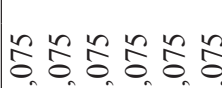

: \& : : : $:$

$\underline{x} \underset{-}{x} \stackrel{x}{-x}$

$\underline{x} \underset{\sim}{-x} \underset{\sim}{-} \stackrel{x}{-}$

$\stackrel{x}{\longrightarrow} \stackrel{x}{-} \stackrel{x}{-} \stackrel{x}{-}$

言 등

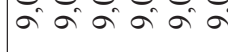

in in in

\& : \& :

\&: : : :

융 \& 8 : \&

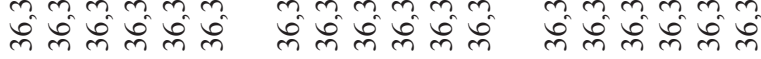

กำ

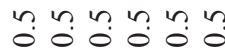

औ?

言高高

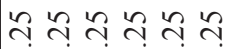

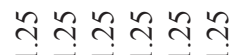

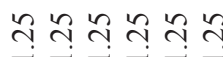

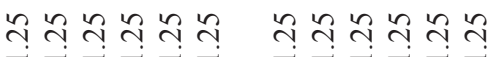

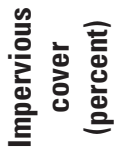

우앙ㅇㅇㅇㅇㅇㅇ

앙ㅇㅇㅇㅇㅇㅇㅇ

우아아앙ㅇㅇㅜ

우아아앙ㅇㅇㅇ

우아아우 


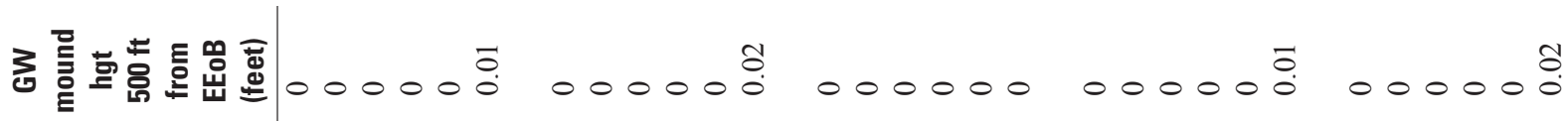

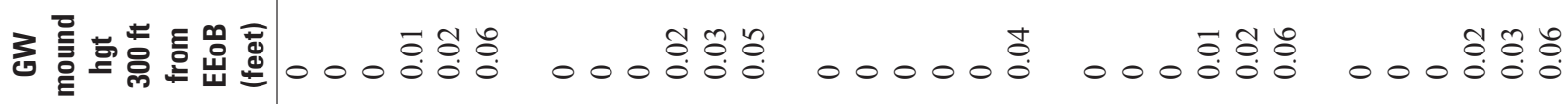

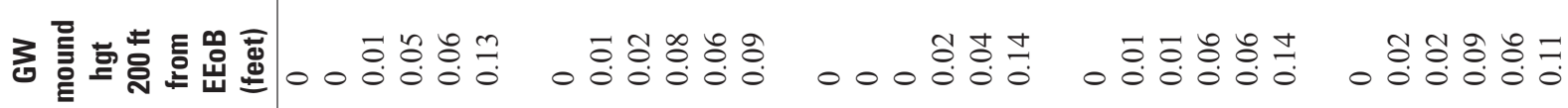

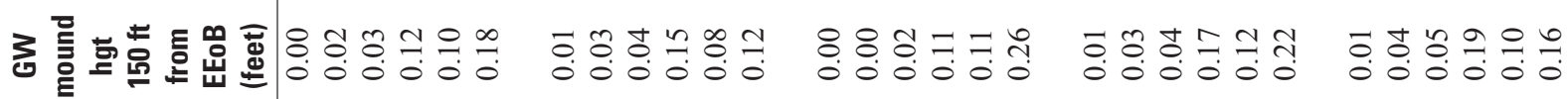

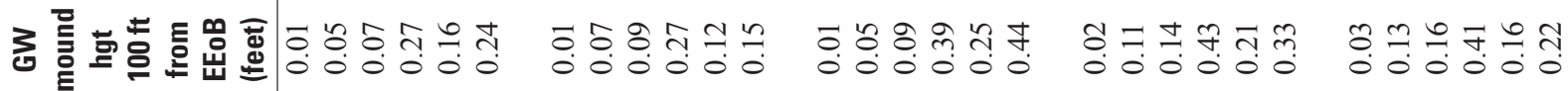

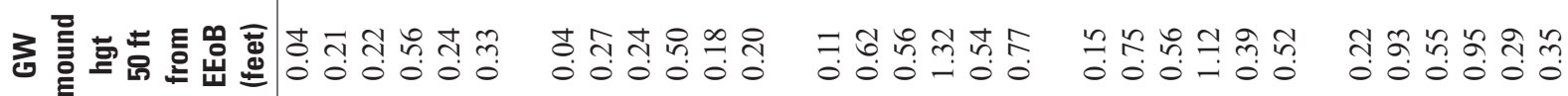

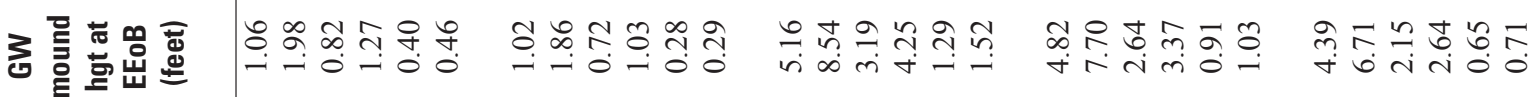

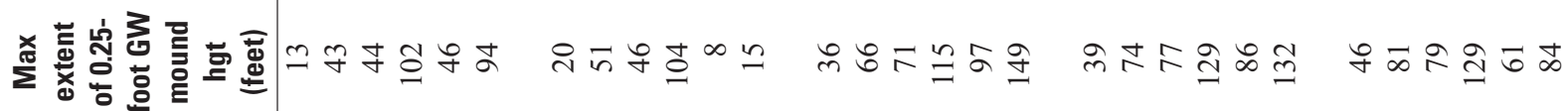

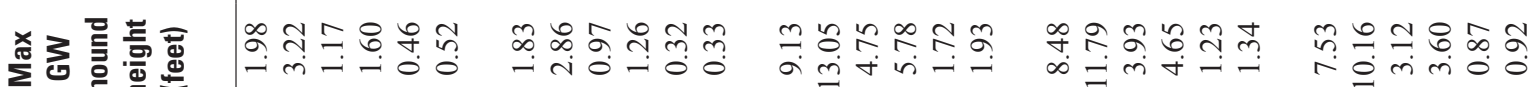
鹿 들

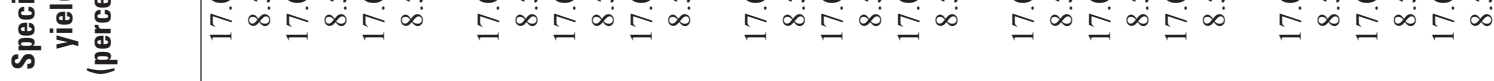

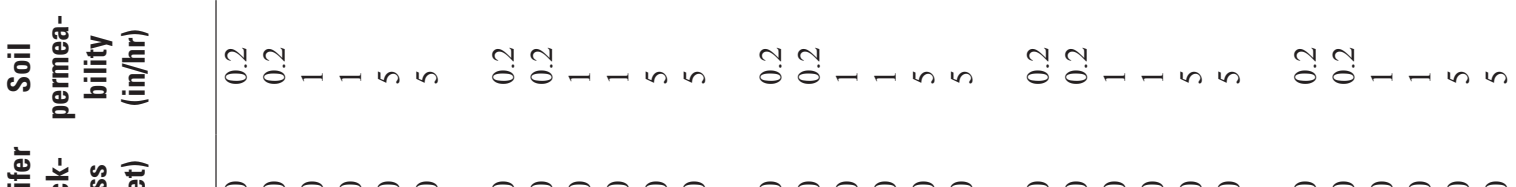

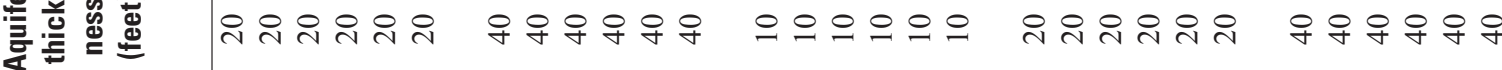
:

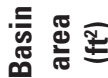

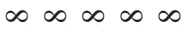
$\ddot{x} \underset{x}{\sim} \stackrel{x}{-} \underset{\sim}{-}$

$\infty \infty \infty \infty \infty \infty$

$\neg-\neg-\neg-\neg-\neg-\neg-$

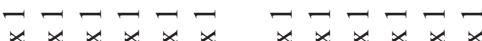
\&: \& \& \& \& \& \& \& \& ñ

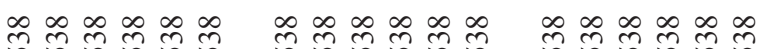

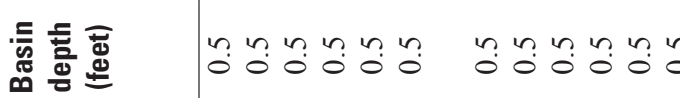

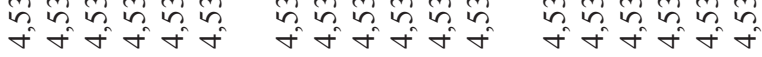

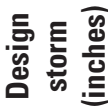

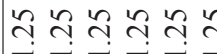

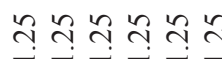

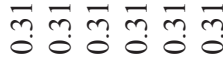

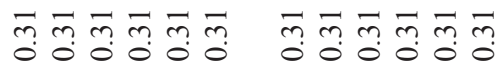
吾言恶

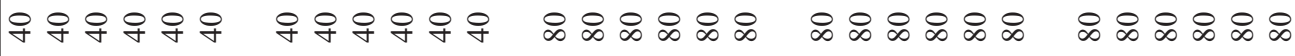
音 这

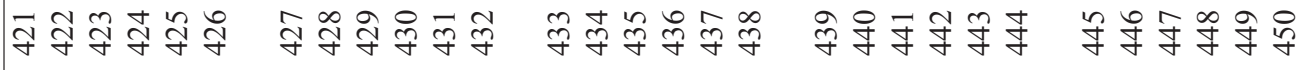




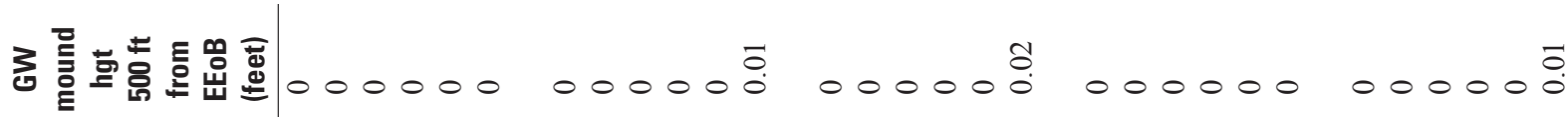

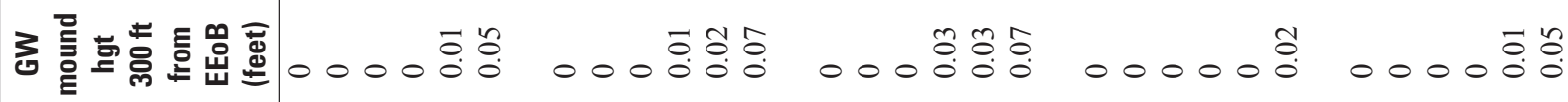

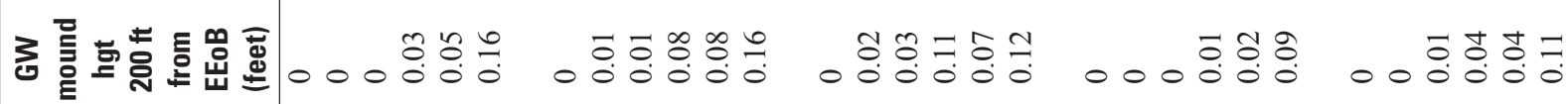

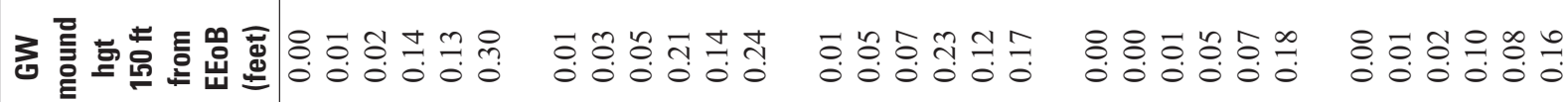

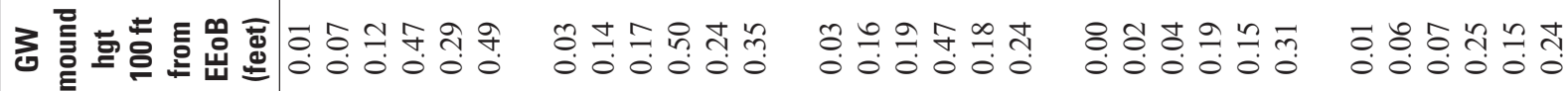

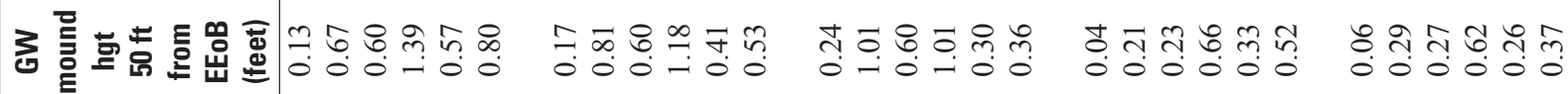

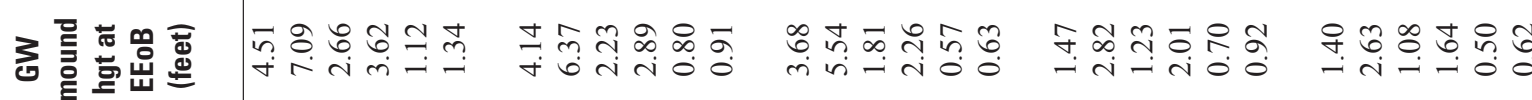

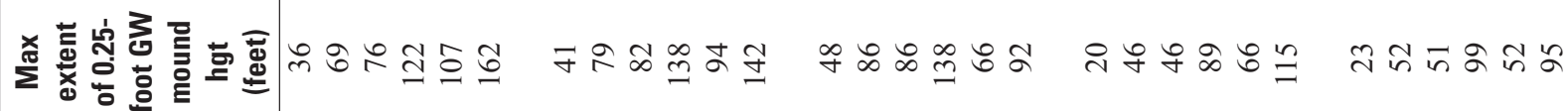

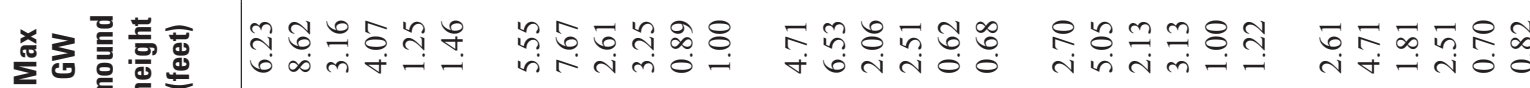

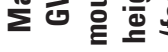

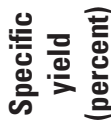

$+\log _{0}$ i

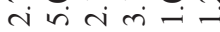

i $\dot{4} \rightarrow 400$

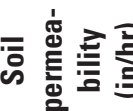

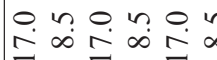

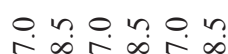

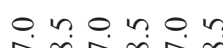

on ono n

o n o no n

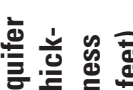

กุ๊

$\stackrel{0}{\pi}$

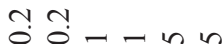

กุํา ชี

กับ กุ่ (5) 


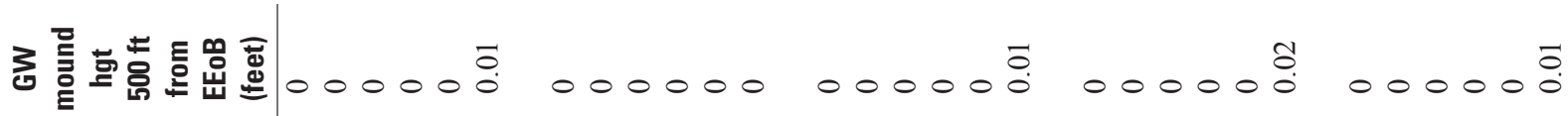

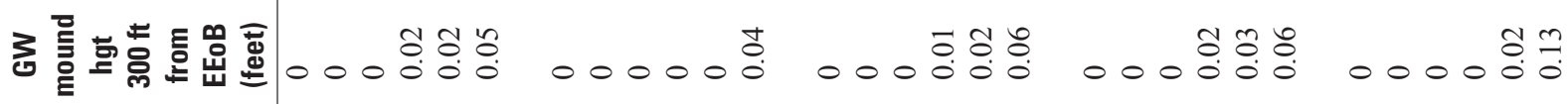

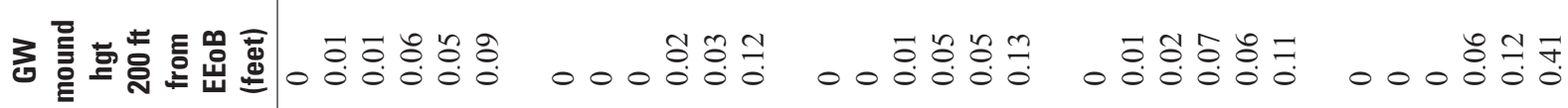

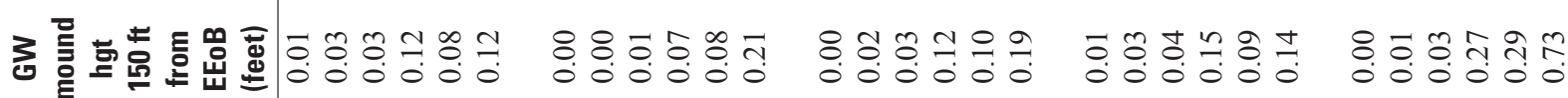

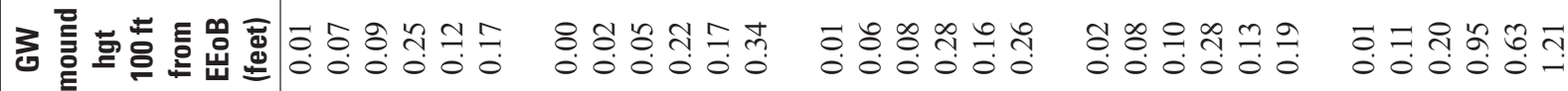

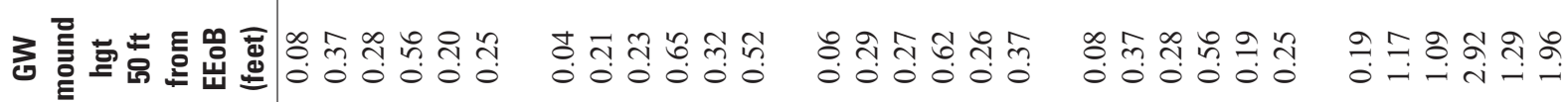

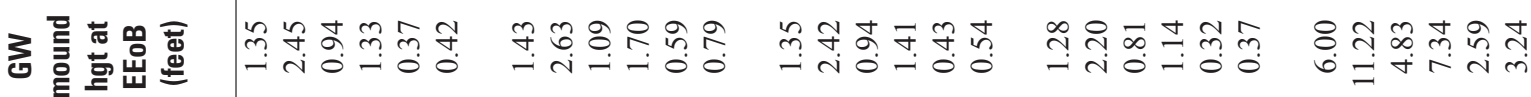

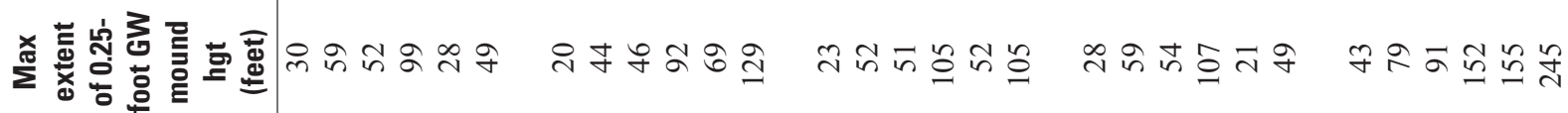

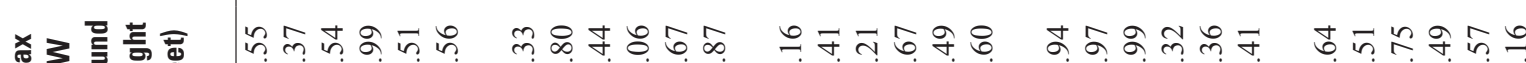

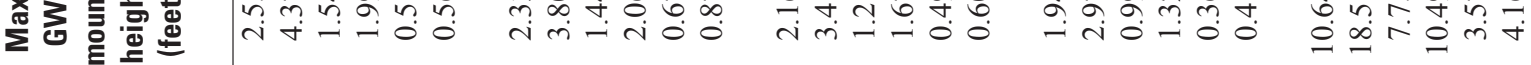
鹿 品高

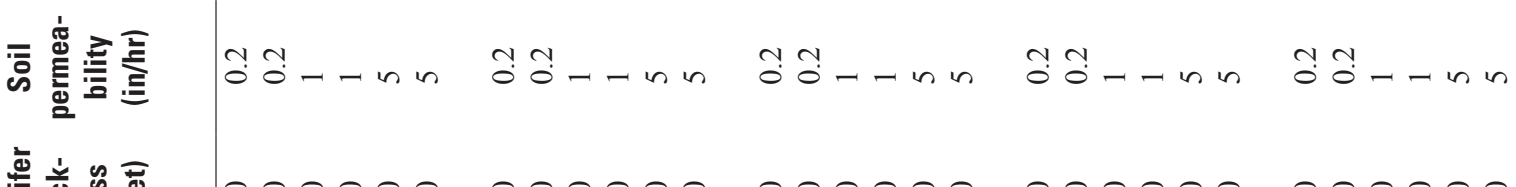

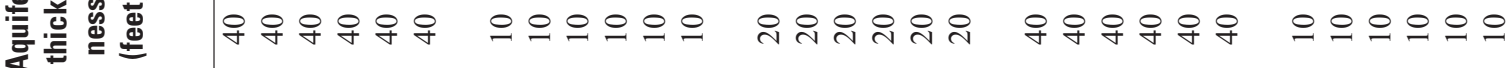

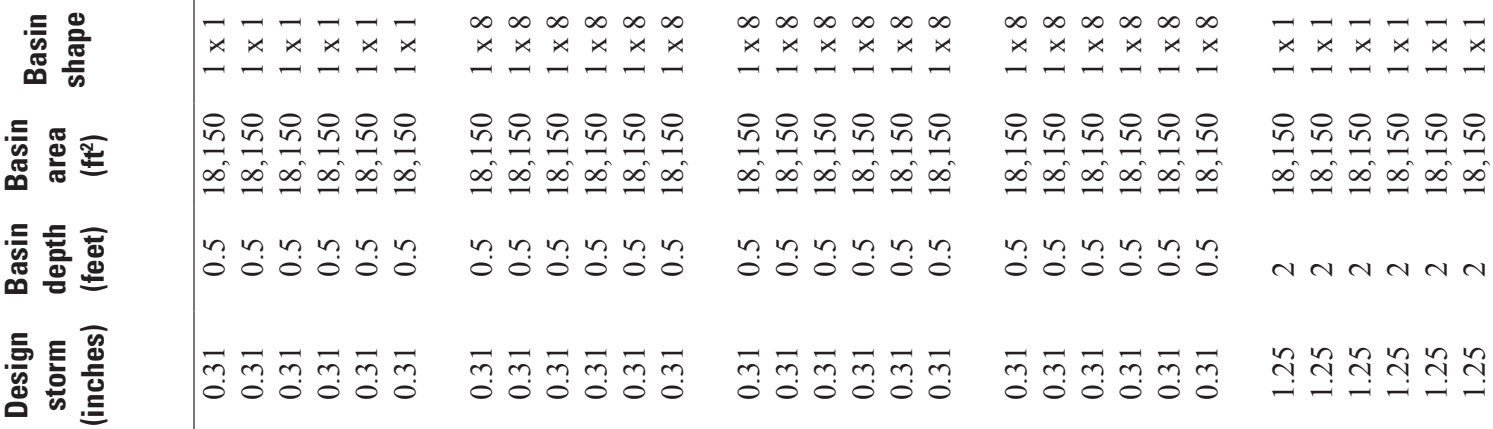
言焉热 音

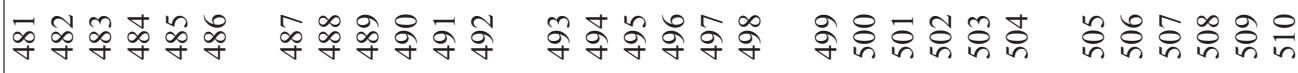




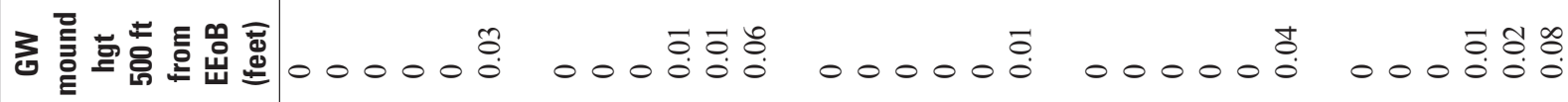

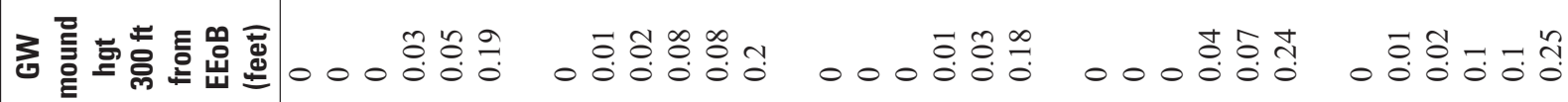

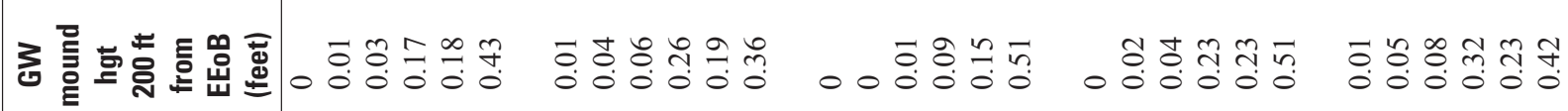

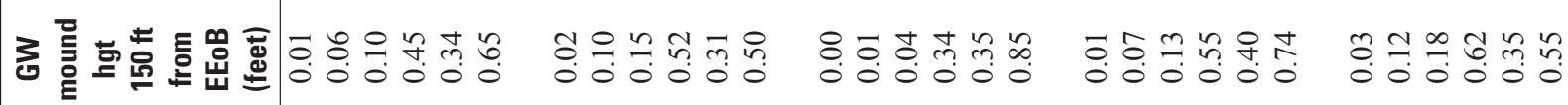

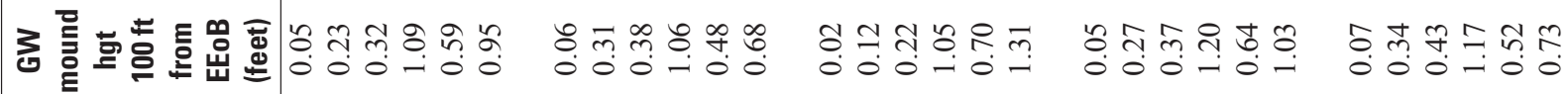

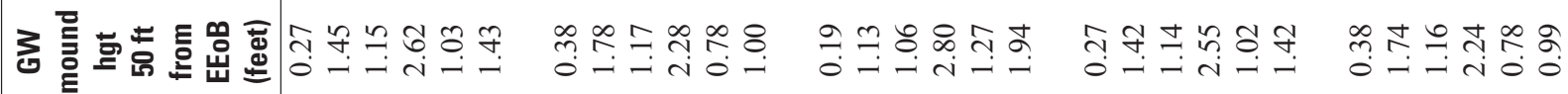

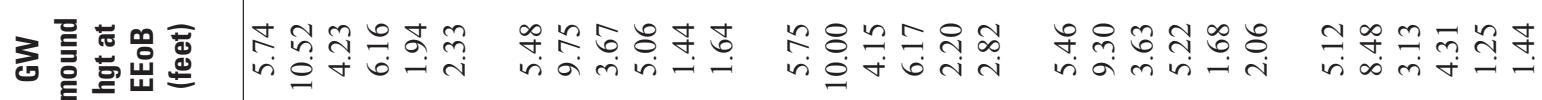

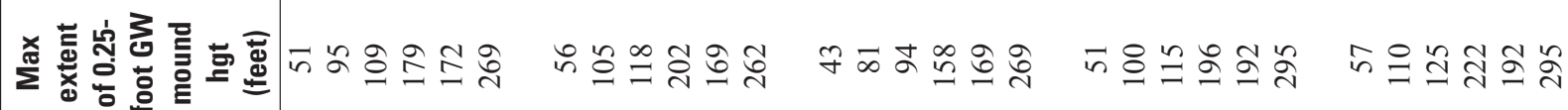

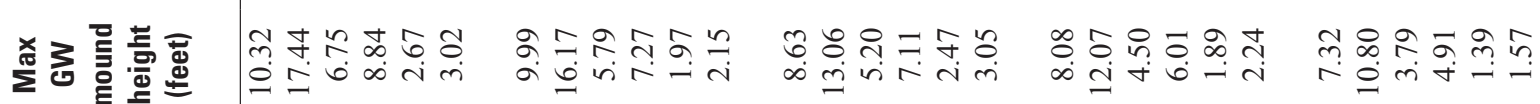

鵕

के

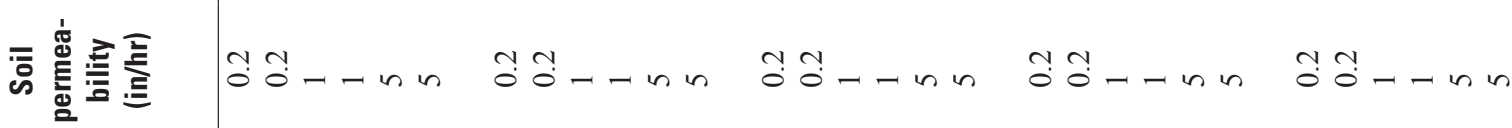

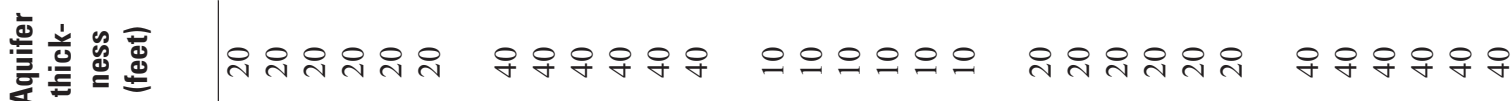

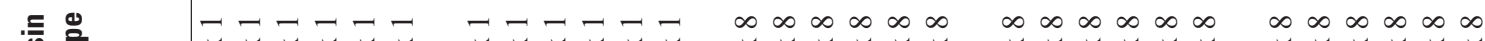

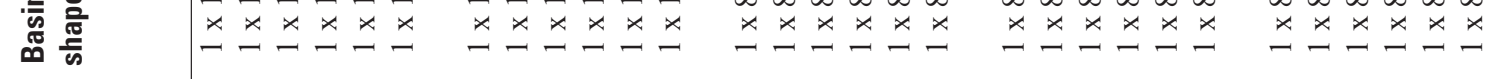

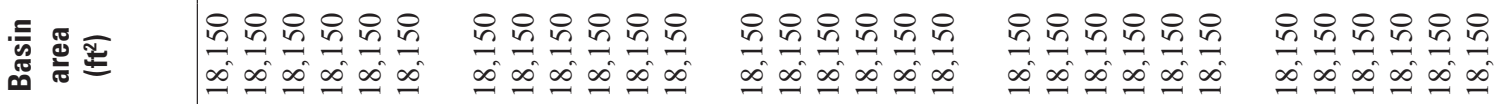

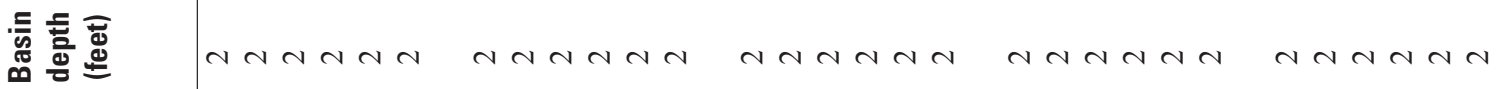

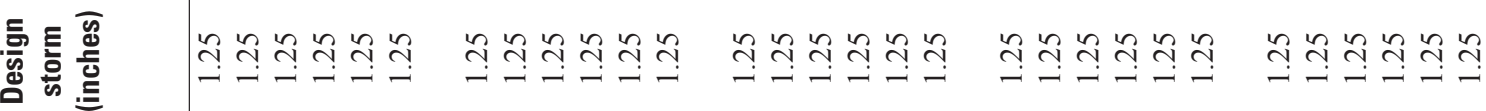

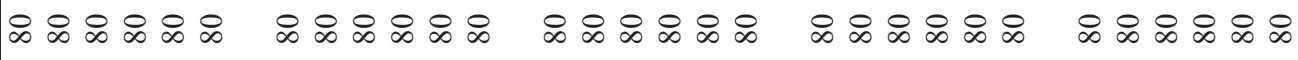




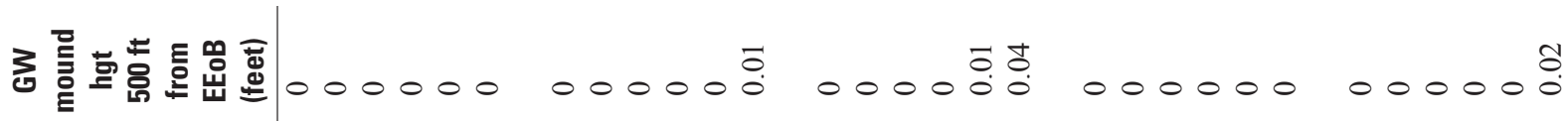

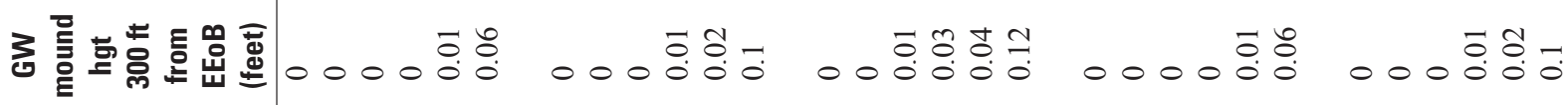

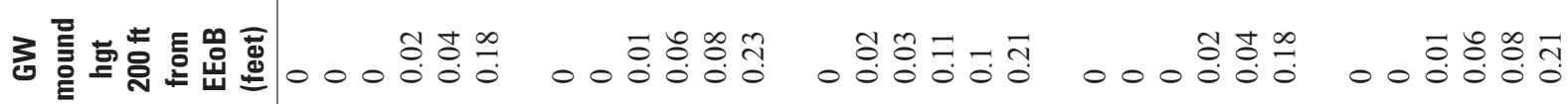

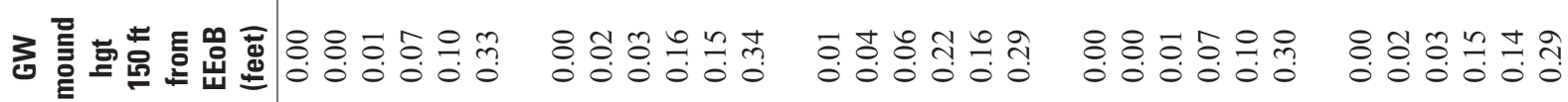

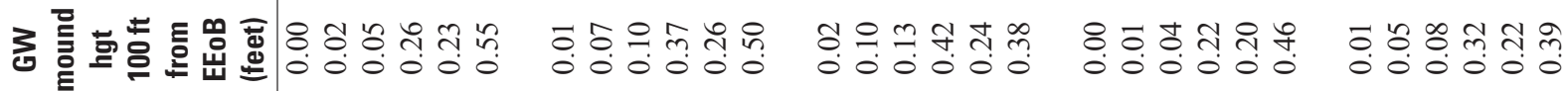

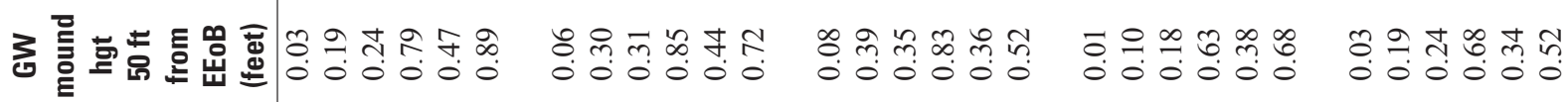

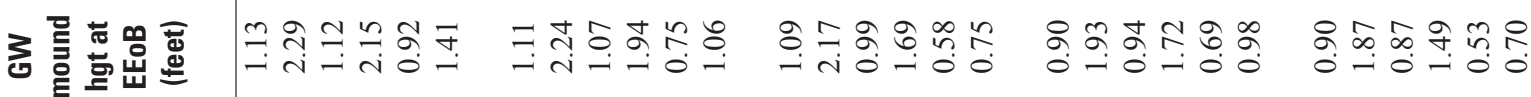

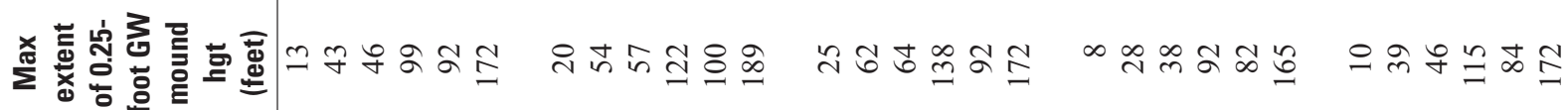

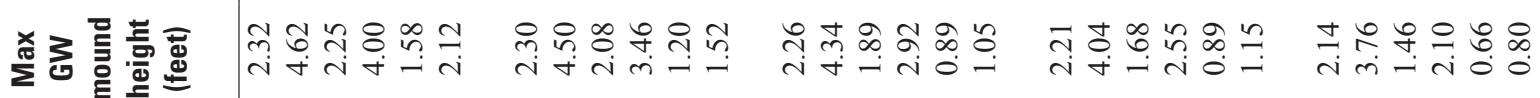

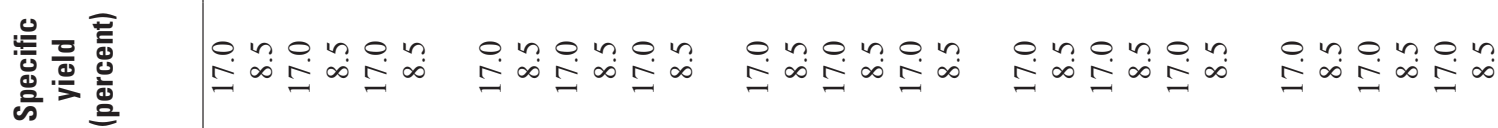

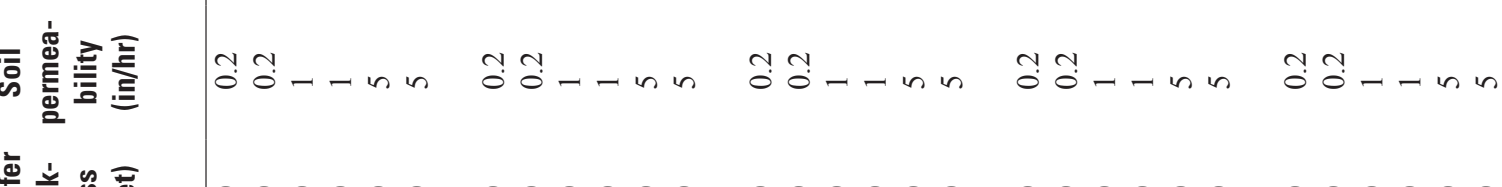

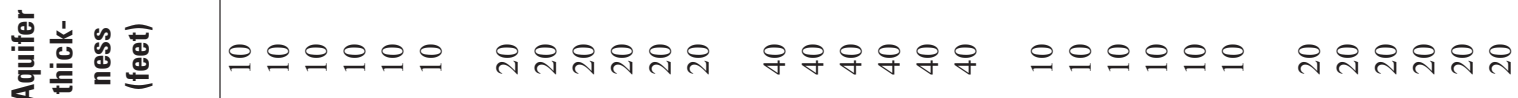

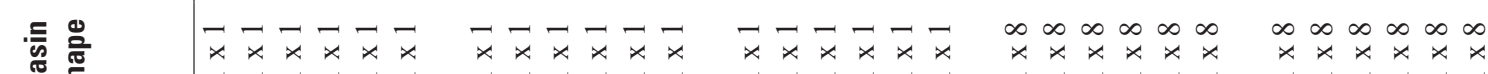

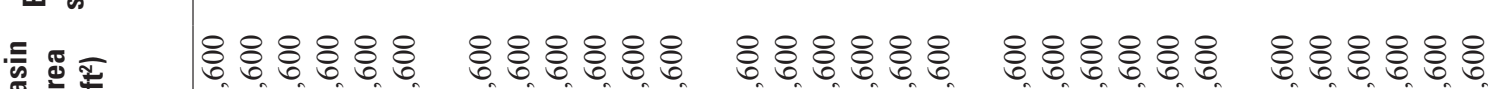

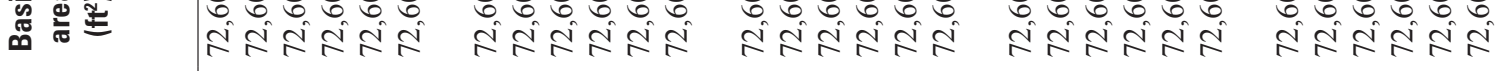
言 衰

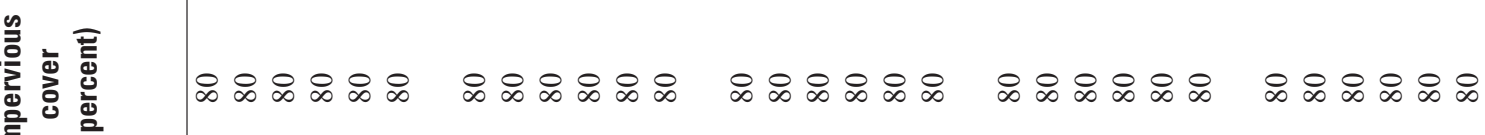
章

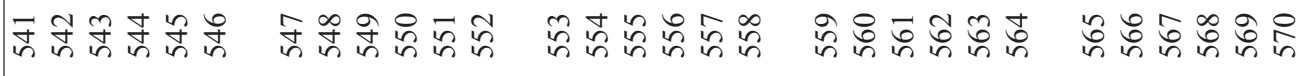




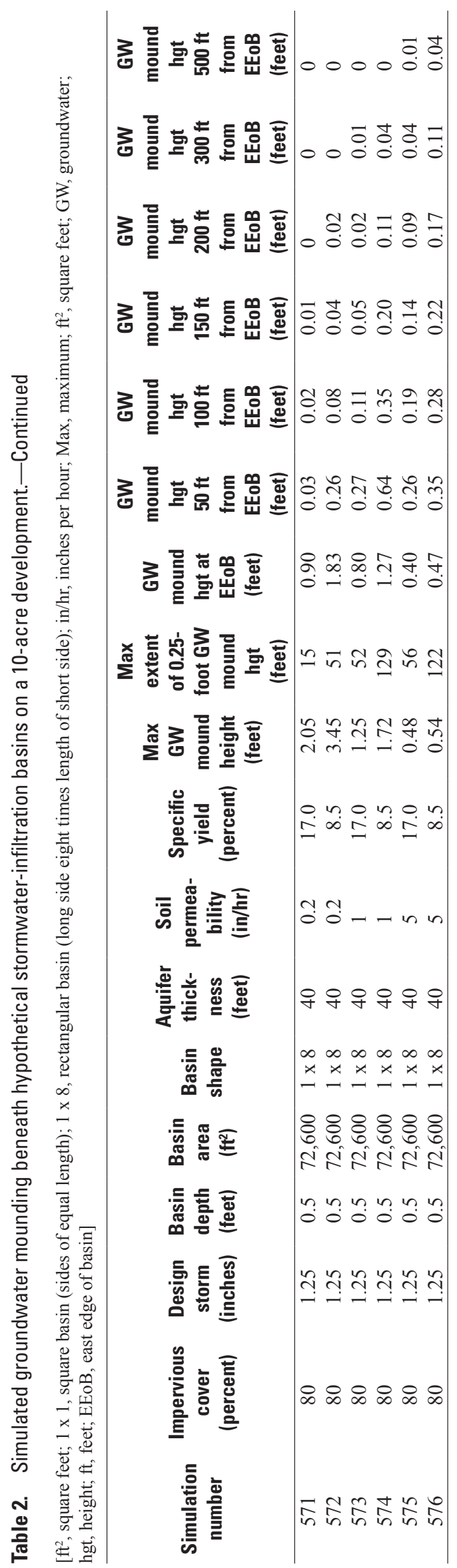




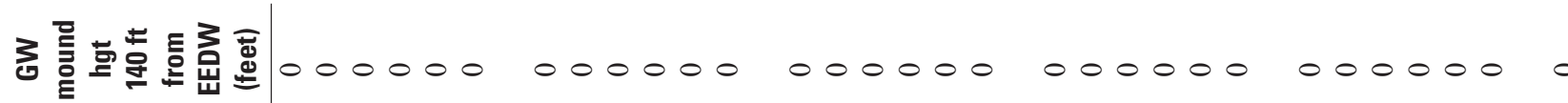

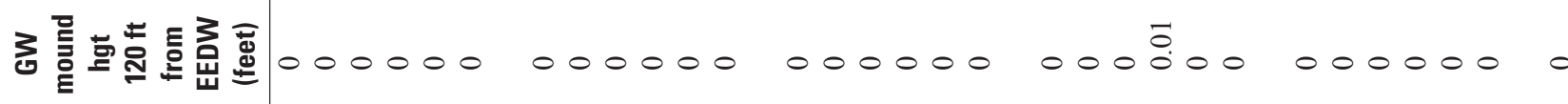

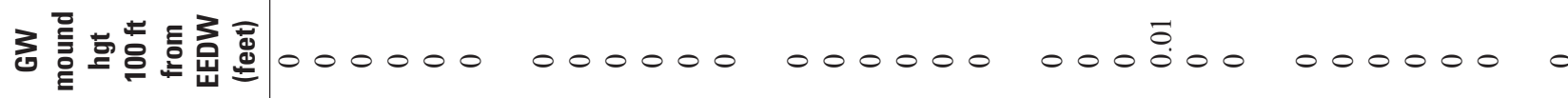

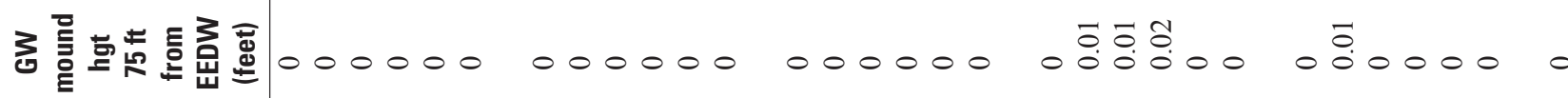

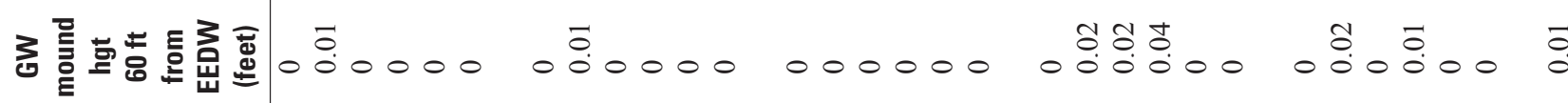

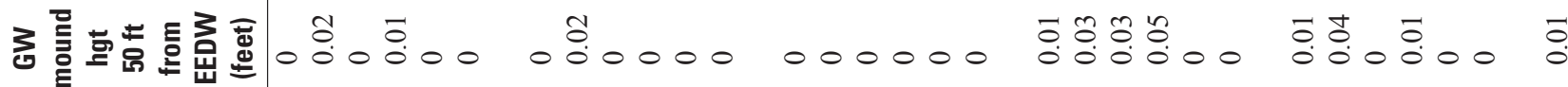

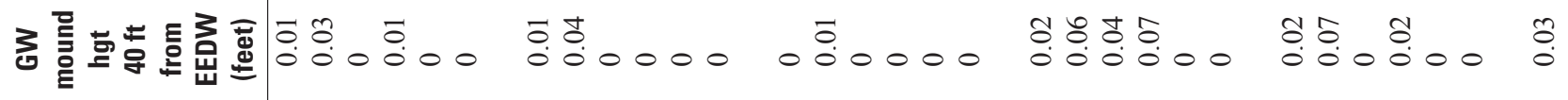

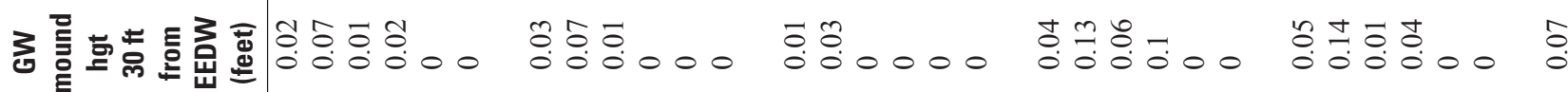

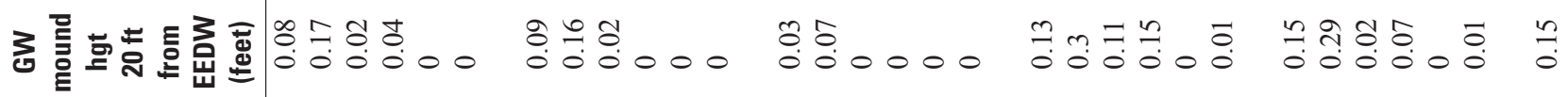

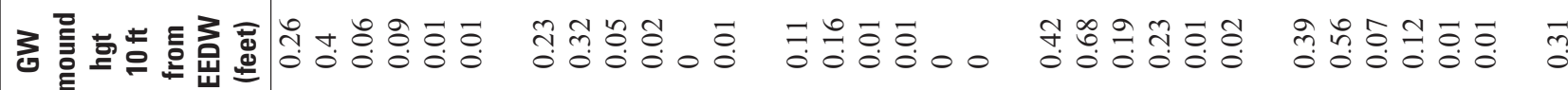

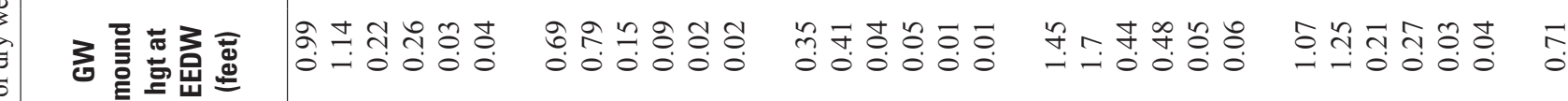

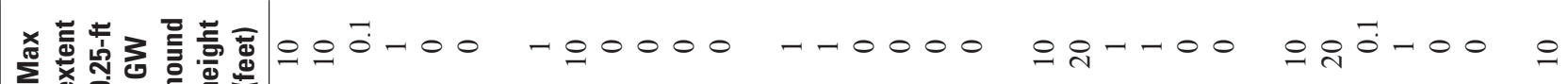

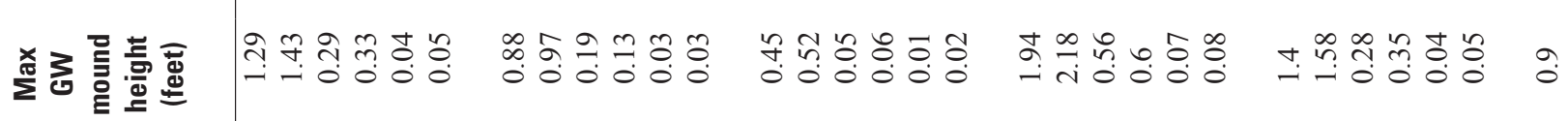
选 응

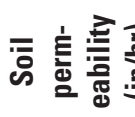

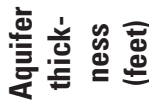

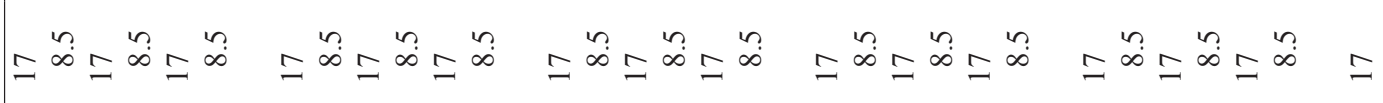

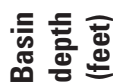

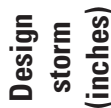
$\frac{m}{m} \frac{m}{m} \frac{m}{m} \frac{m}{m} \frac{m}{m}$ กั่ กุ กูก

으으으으응 위유유유

ำ ำ

กุ้ กั่

กุด

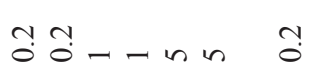

文充

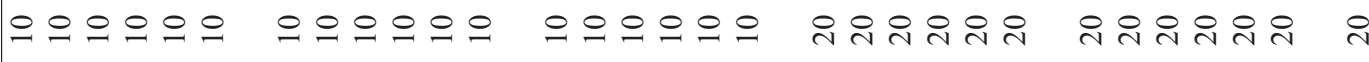




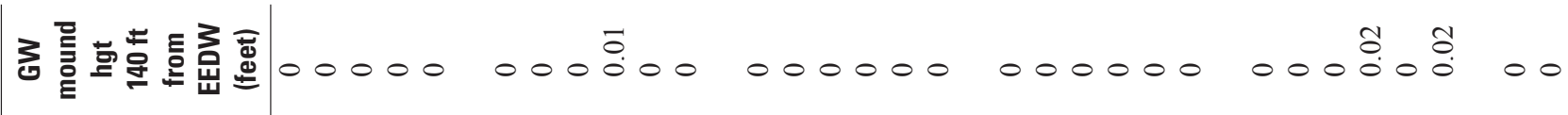

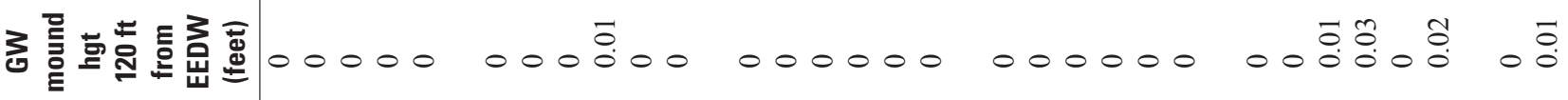

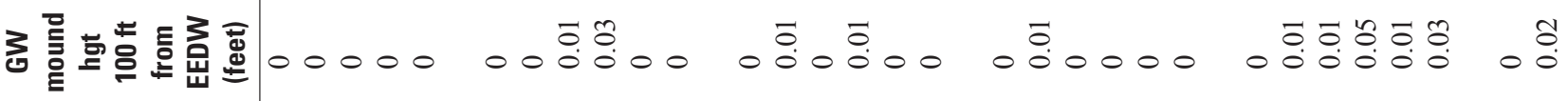

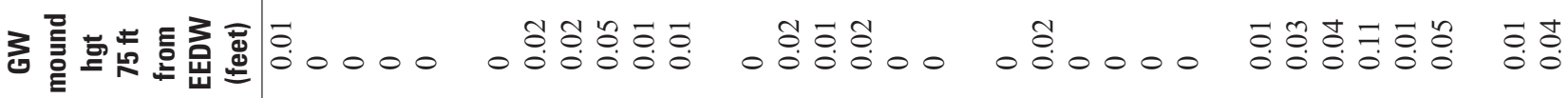

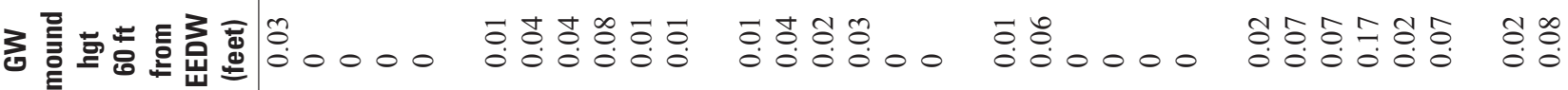

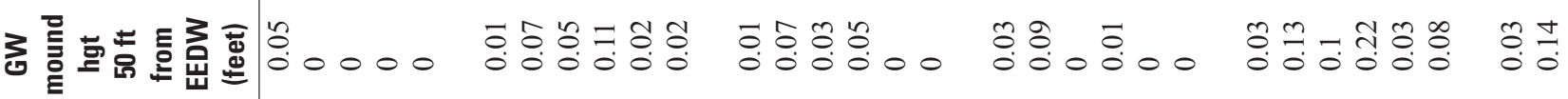

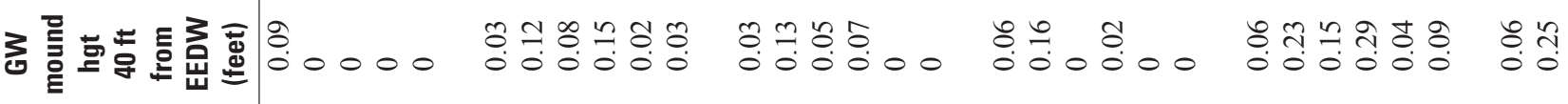

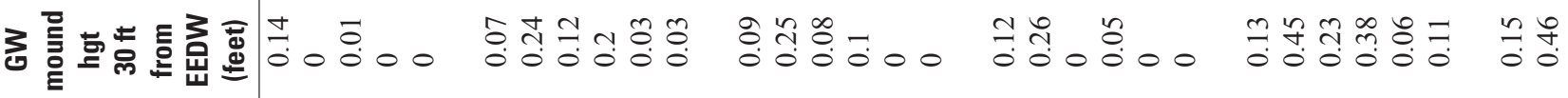

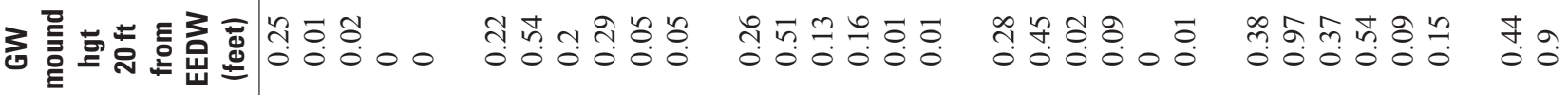

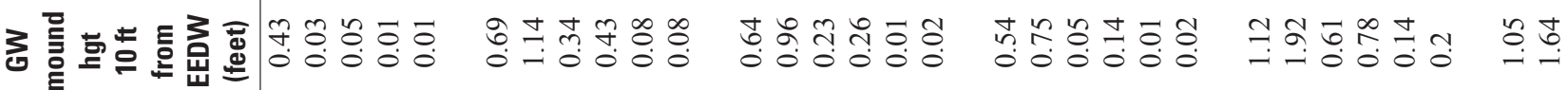

에으융ㅇ

규잉ㅇㅇ

융-

ㅇํ윳ำㄴ

수우

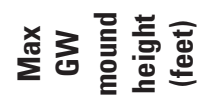

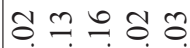

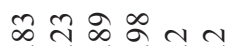

눙 in

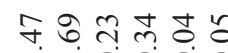

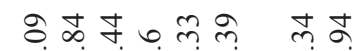

包 등

造卷

$\ddot{\infty}=\ddot{\infty}=\ddot{\infty}$

$=\stackrel{n}{=\infty}=\stackrel{n}{\infty}=\infty$

$=\stackrel{n}{=}=\stackrel{n}{\infty}=\stackrel{n}{\infty}$

$=\stackrel{n}{=}=\stackrel{n}{\infty}=\stackrel{n}{=}$

$=\stackrel{n}{=}=\stackrel{n}{\infty}=\stackrel{n}{=}$

$=\stackrel{n}{\infty}$

的言害总

กุร กุด.

กับ

กุด

กุ

กุ้ ชุำ

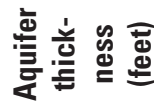

아웅ㅇㅇㅇㅢ

으으으으으으

ㅇํำ ำกำ

의 $q$ 앙

으으으으으으

유 우

言

言

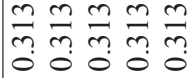

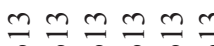

$\operatorname{4an} 4 \sin$

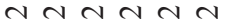

市

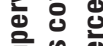

으류유ํำ

ơ

$m \frac{m}{m} m \frac{m}{m} m$

$m m m m m$

$m \frac{m}{m} \frac{m}{m} \frac{m}{m}$

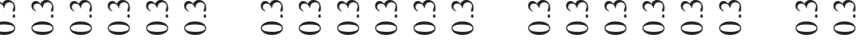




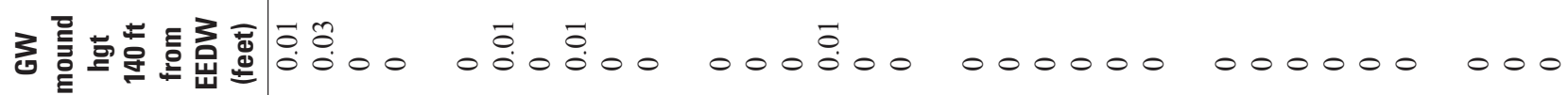

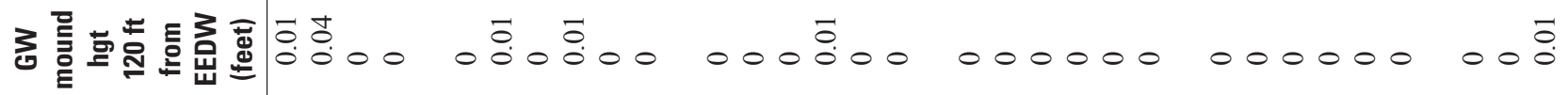

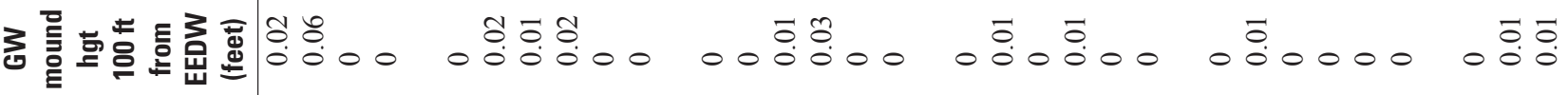

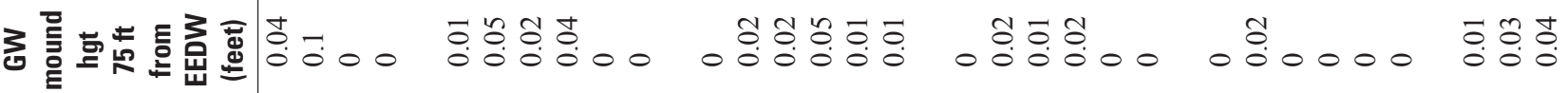

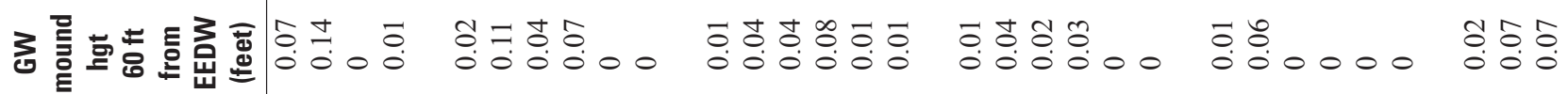

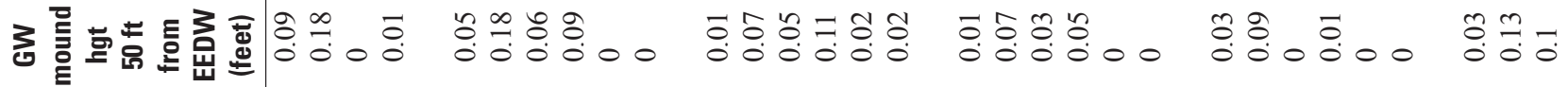

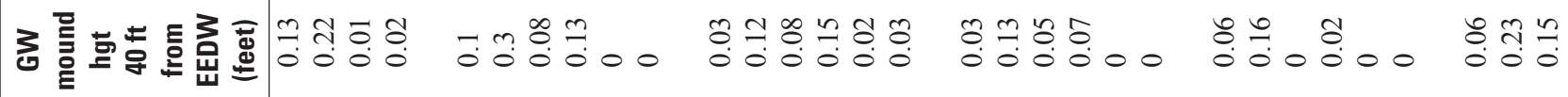

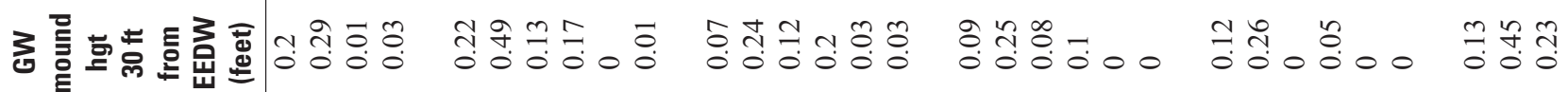

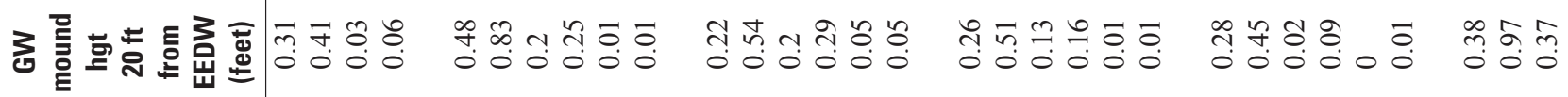

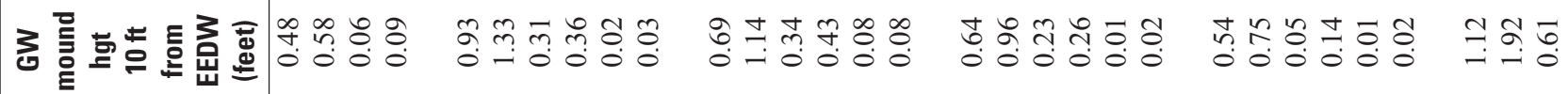

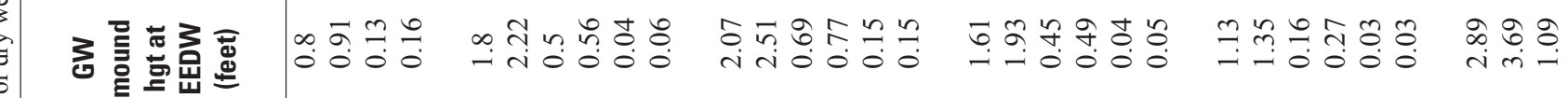

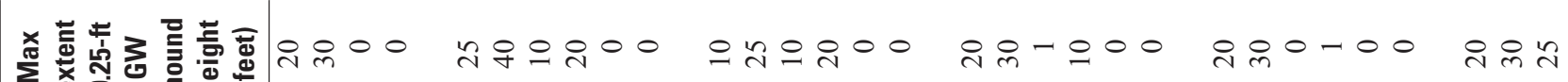

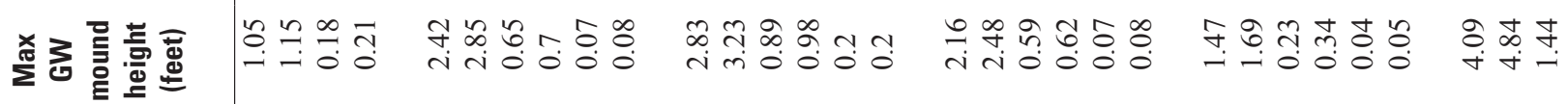

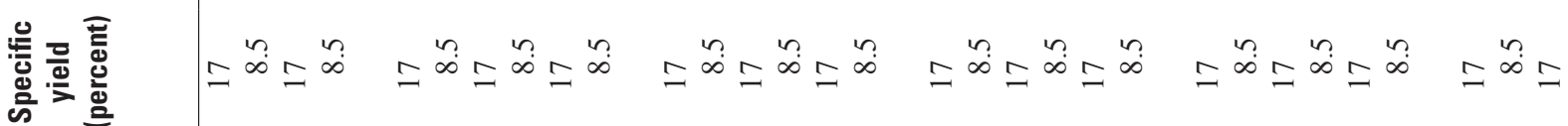

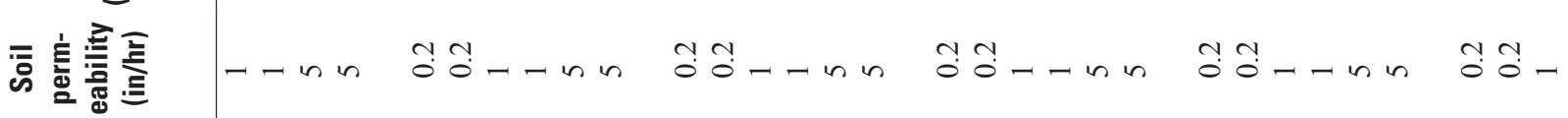

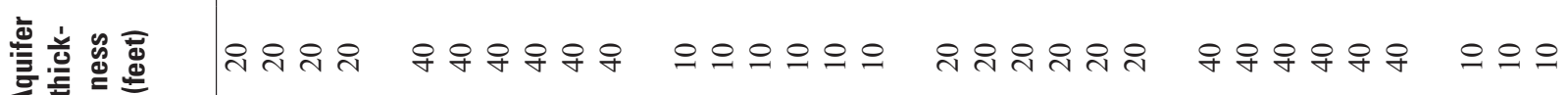

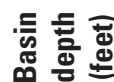
衰

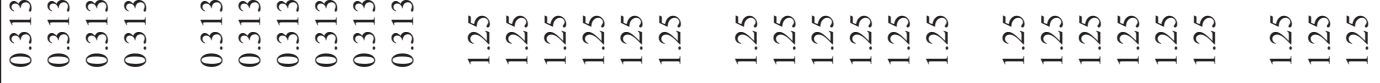

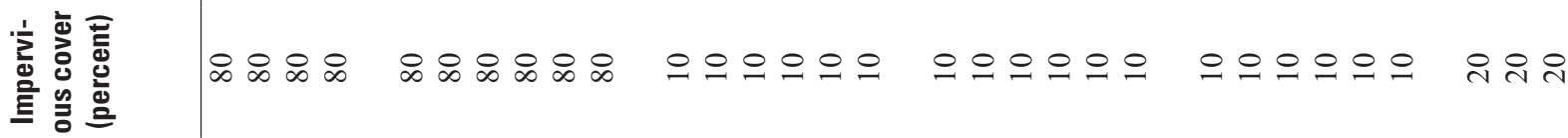

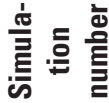

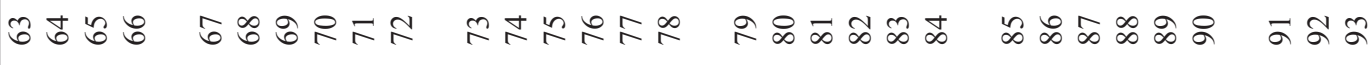




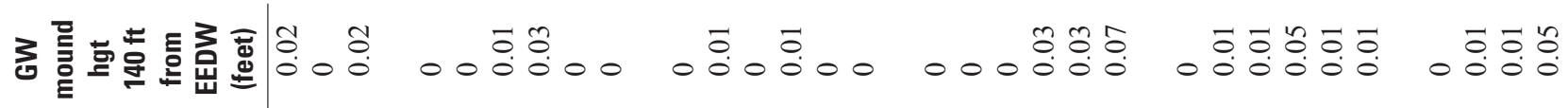

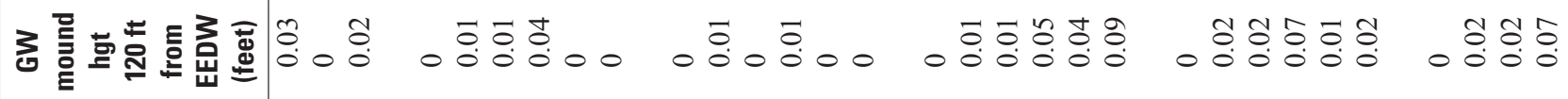

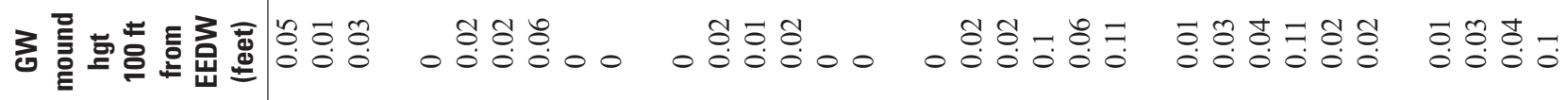

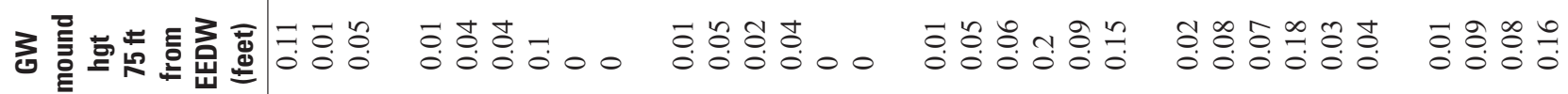

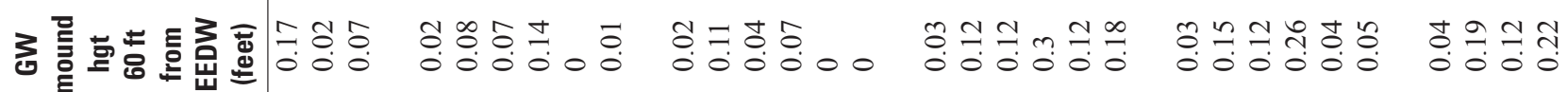

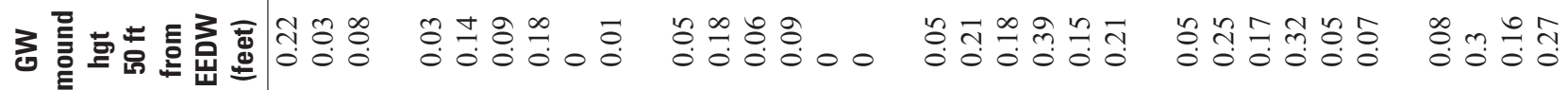

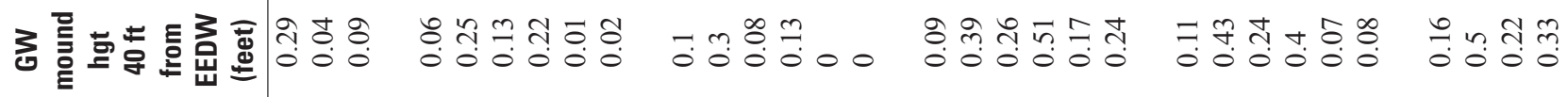

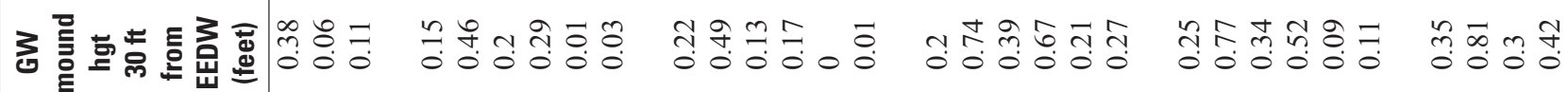

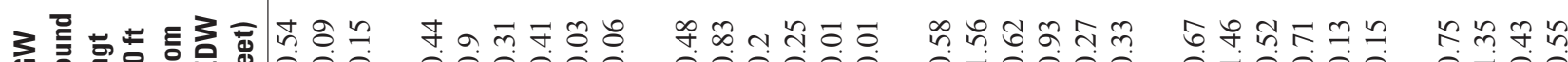

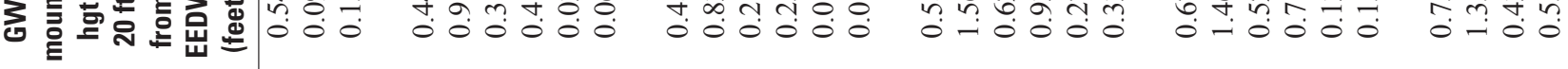

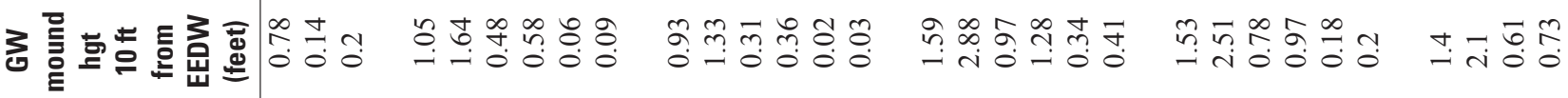

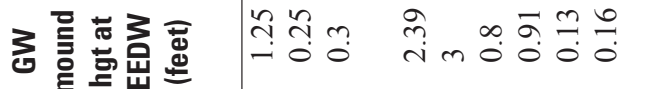

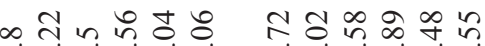

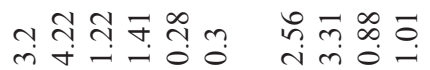

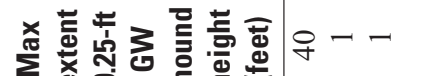

구융ㅇㅇㅇ

광ㅇㅇㅇㅇㅇㅇ

세앙ㅇㅇㅇㅈㅇㅛ

유요요요 -

유용요 요

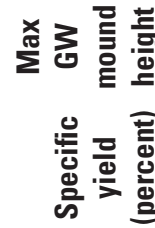

में क्ष

ๆ

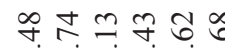

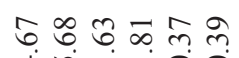

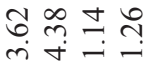

的言高焉

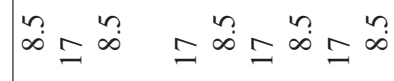

$=\stackrel{n}{\infty}=\stackrel{n}{\infty}=\infty$

$=\stackrel{n}{=}=\stackrel{n}{=}=\ddot{\infty}$

$=n^{n}=\stackrel{n}{\infty}=\stackrel{n}{\infty}$

$=\infty n^{n}=\infty$

产竞总总

กำ

กุก

กุ่

กุ ข

กับ กุด-

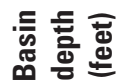

预

กุ่

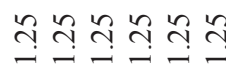

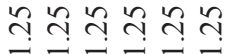

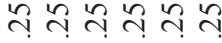

กิกลุก๊

กุกิ กุก กิ

文

要递

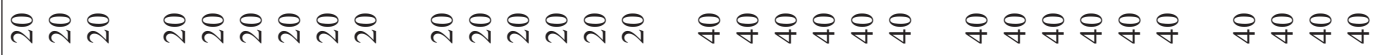




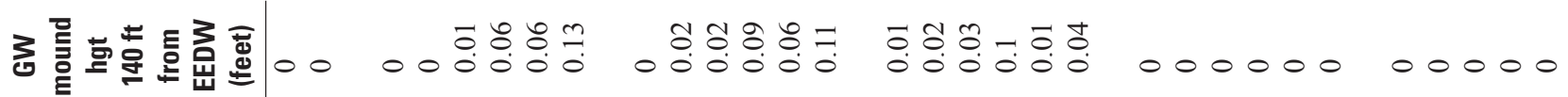

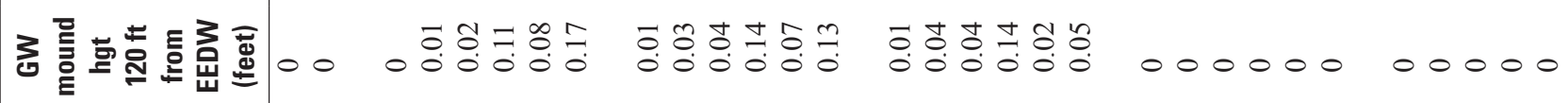

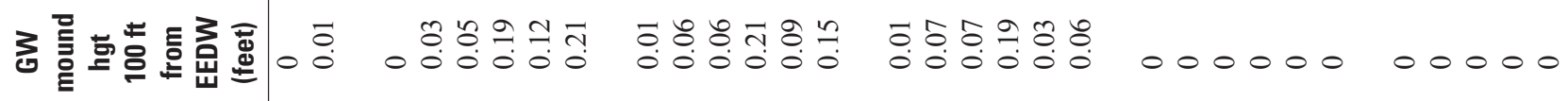

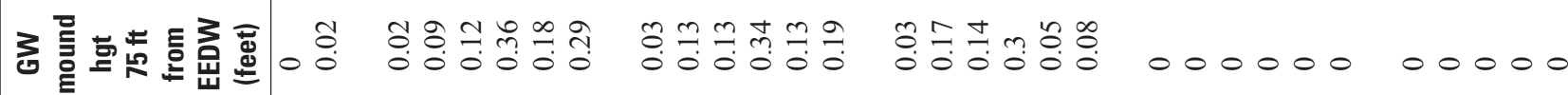

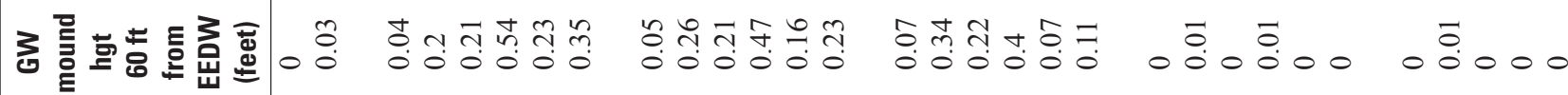

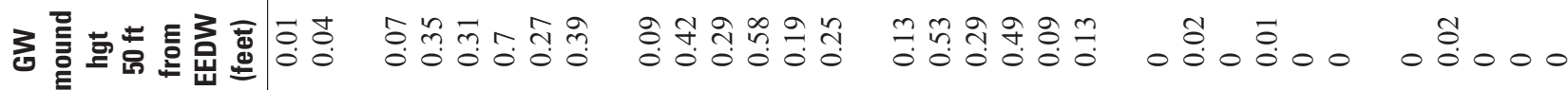

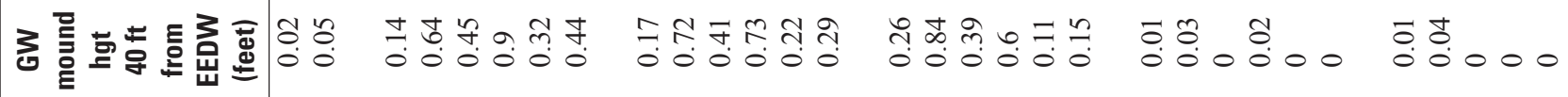

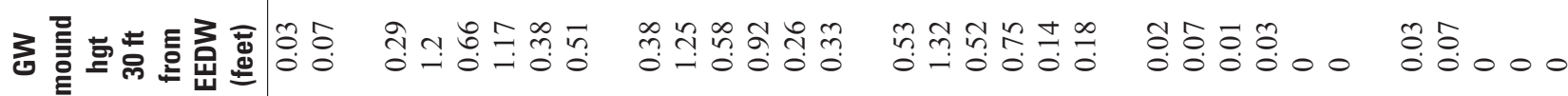

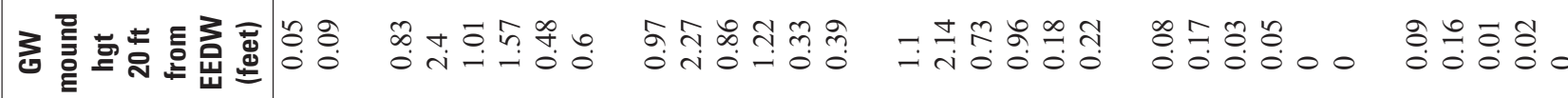

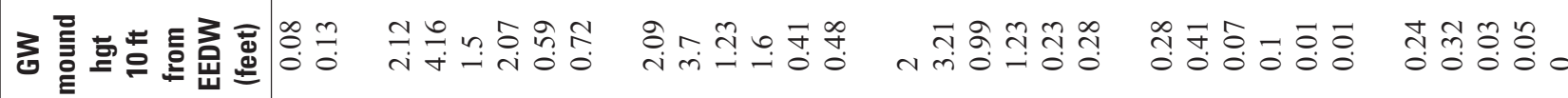

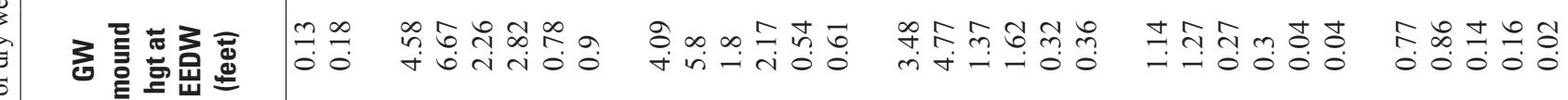

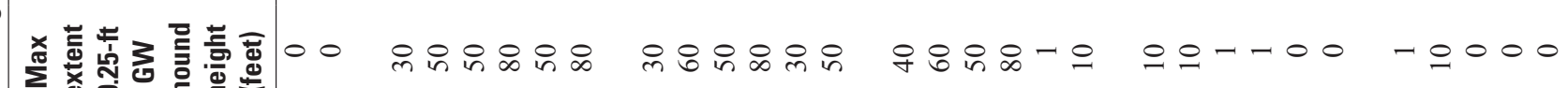

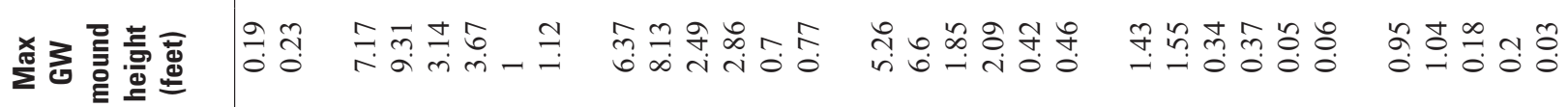

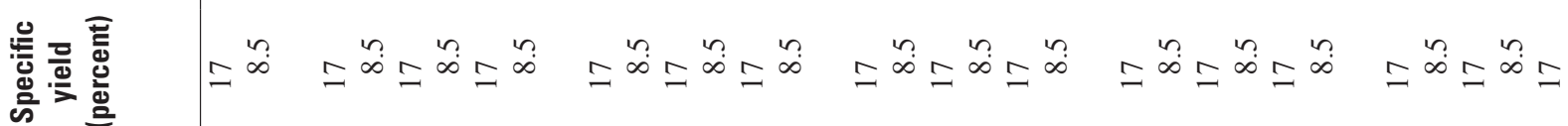

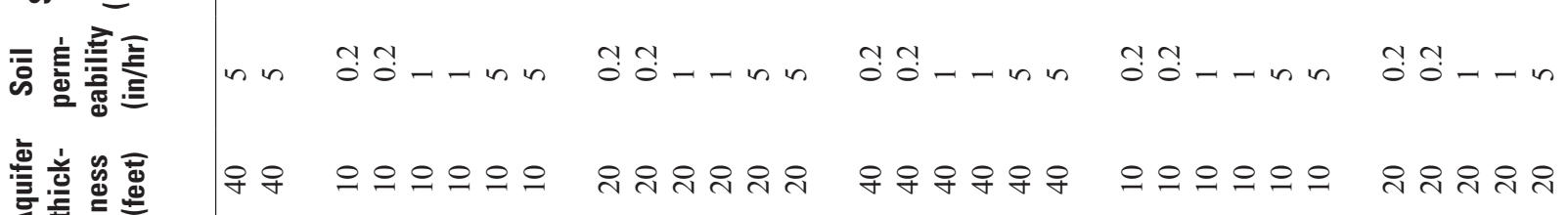

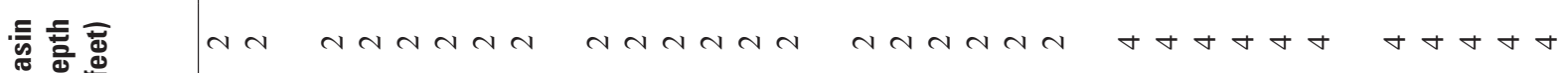
$\infty$ 衰

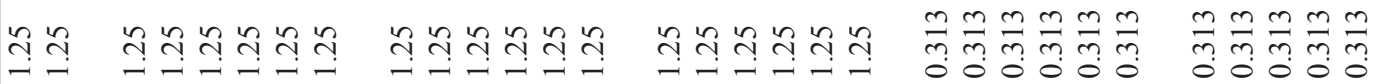

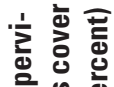
宣号总 아 突

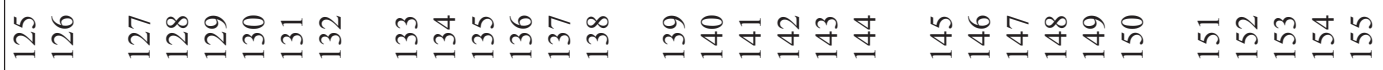




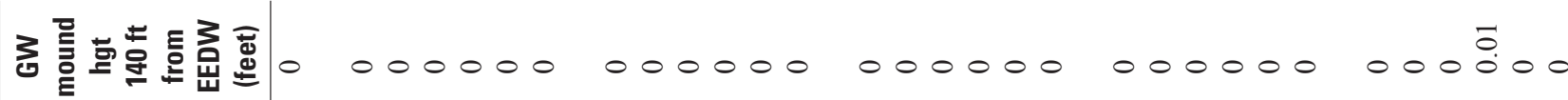

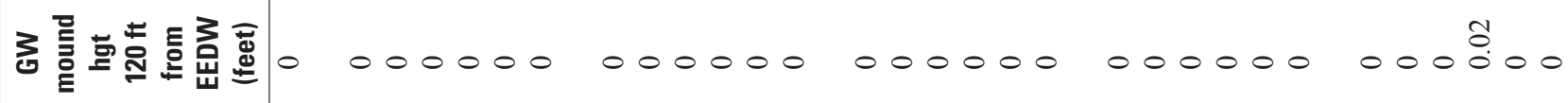

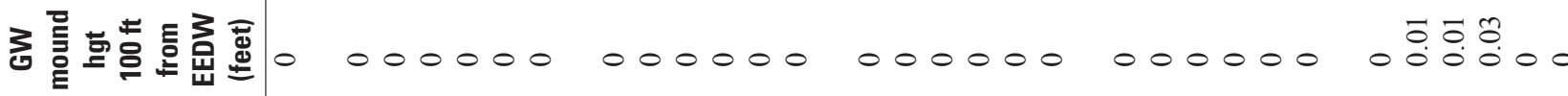

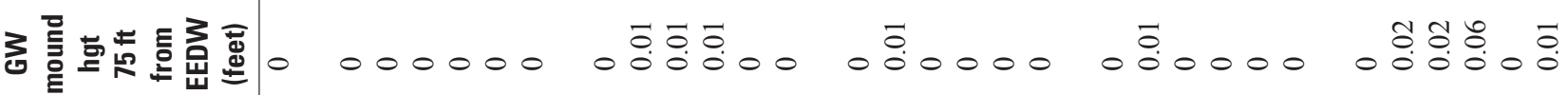

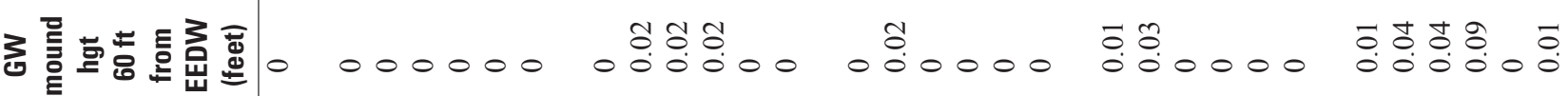

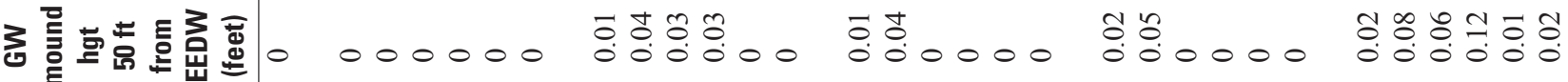

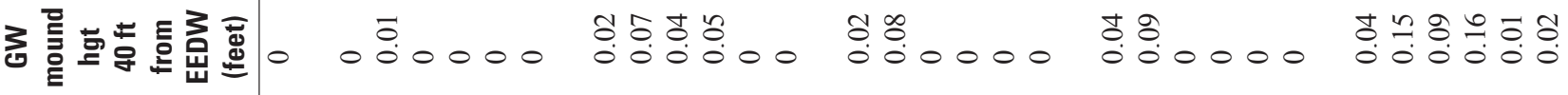

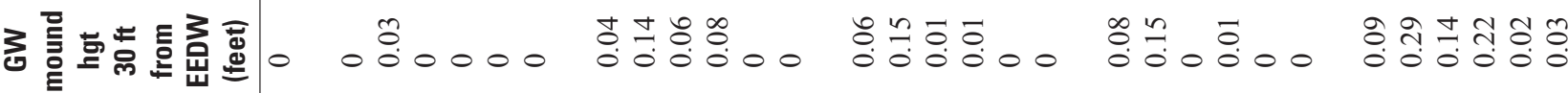

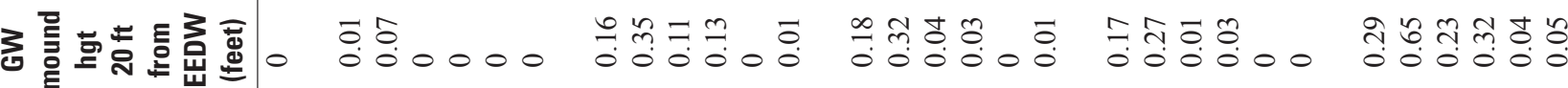

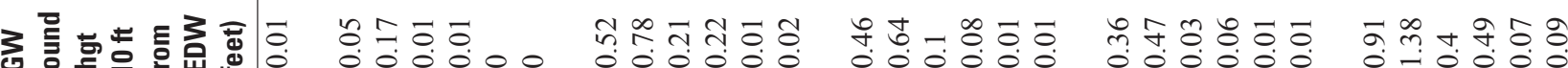

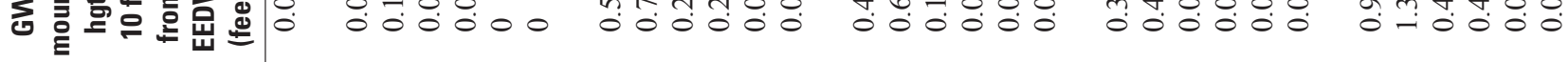

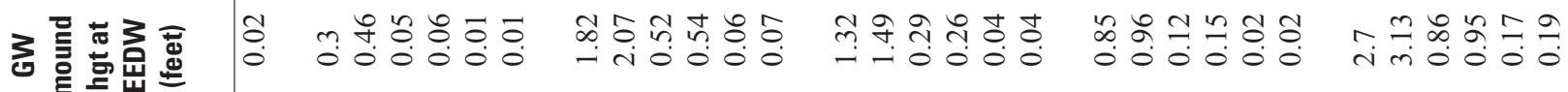

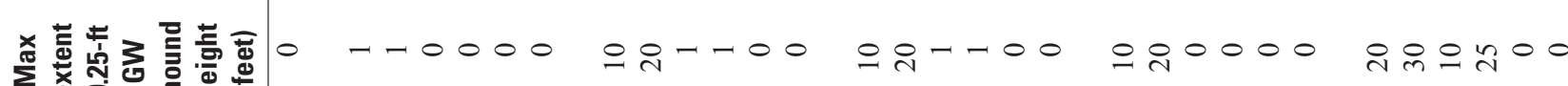

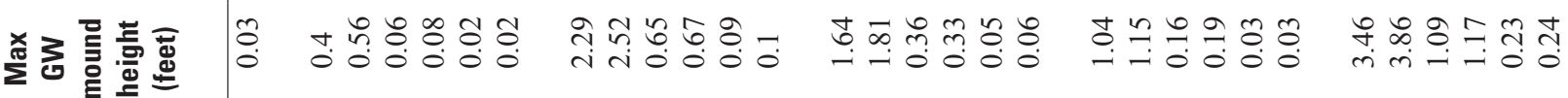
氖 के

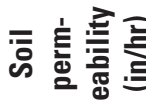

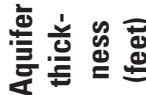

등 호웛용

言

$m \quad m m m m m$ $=\stackrel{n}{=}=\stackrel{n}{=\infty}=\infty$

$=\stackrel{n}{=}=\stackrel{n}{=}=\infty$

$=\stackrel{n}{=}=\stackrel{n}{=}=\infty$

$=\stackrel{n}{\infty}=\stackrel{n}{=}=\stackrel{n}{=}$

$=\stackrel{n}{\infty}=\stackrel{n}{\infty}=\stackrel{n}{\infty}$

察言

宣哭总

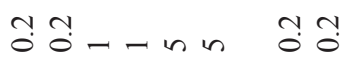

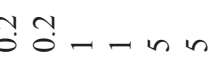

กับ บุ

กับ บุ

ก ก

o- $-n$

ํํㅇ.

or- 0 n

紊

$\because$ ถ⿻ำ

으으으으으으

ํํํํำ ิํ

아앙ㅇㅇㅇㅇㅇㅇ

으으으으으으

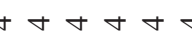

$m m m m m$

$m n n m m m$

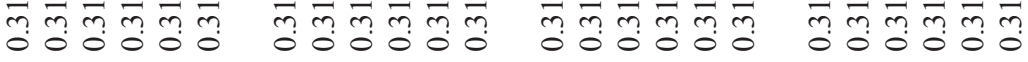

$m \frac{m}{m} \frac{m}{m} \frac{m}{m} \frac{m}{m} \frac{m}{m} \frac{m}{m} \frac{m}{m} \frac{m}{m}$

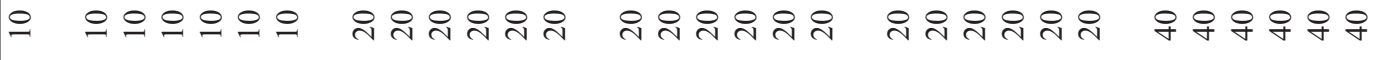




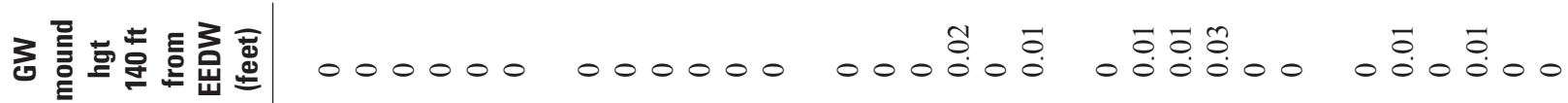

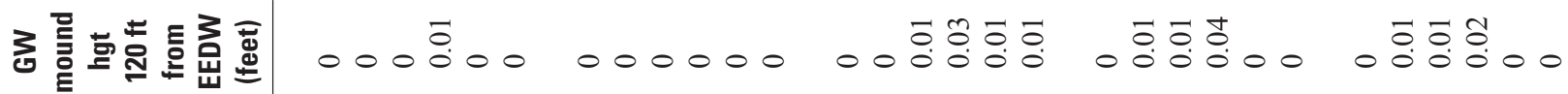

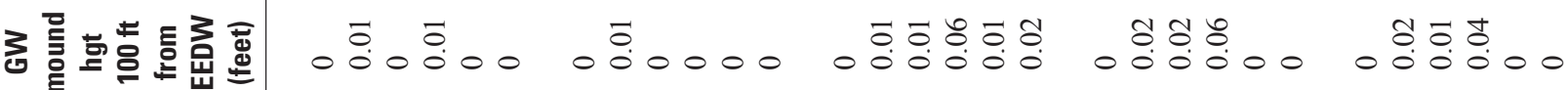

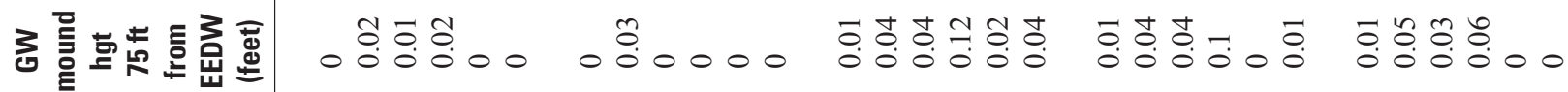

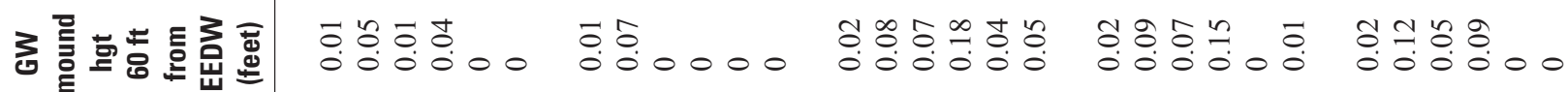

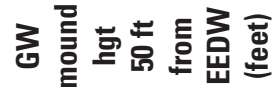

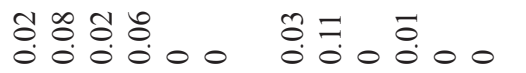

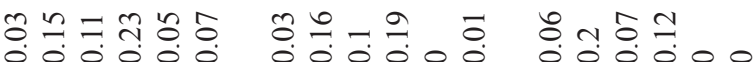

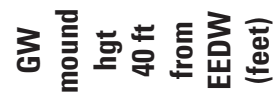

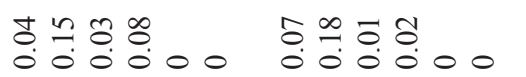

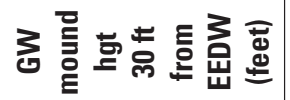

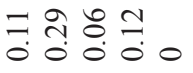

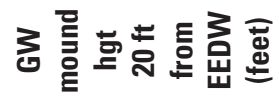

กิเกตรี 000000

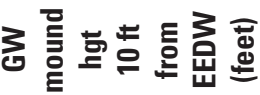

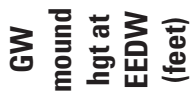

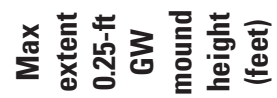

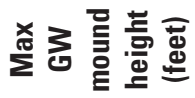

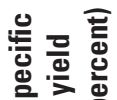

的言要恋

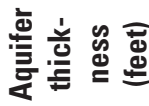

言 咅

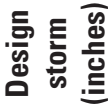

完产

豆虽总

突 $\infty$ 苟

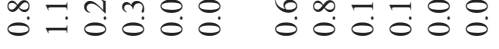

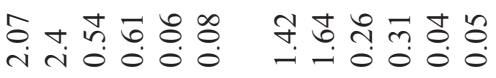

유융이

규가이

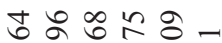

i i 00000

ㅇำ

$=\stackrel{n}{\infty}=\stackrel{n}{\infty}=\stackrel{n}{\infty}=\stackrel{n}{\infty}=\stackrel{n}{\infty}=\frac{n}{\infty}$

กั่ กั่

ก.

กุ้ ชุ่

위유융ํํ

4.

$m m m m m$

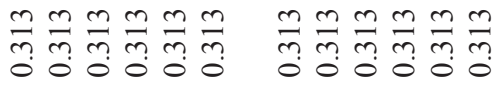

우앙ㅇㅇㅇㅇㅇㅇㅇ

$\infty \stackrel{\infty}{\infty} \approx \sigma$
ธิธี่ำ요
우아아아아우

$\theta+\theta+\theta$

$\stackrel{m}{m} \frac{m}{m} \frac{m}{m} \frac{m}{m}$ o.

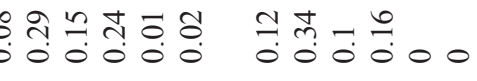

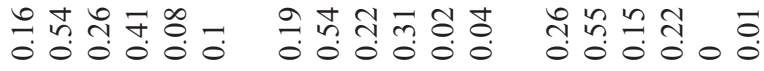

चึ.

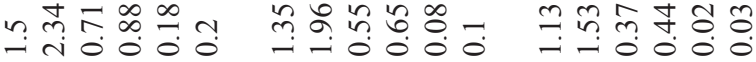
ॠ

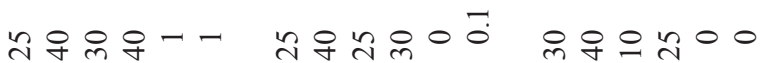

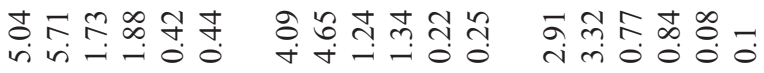

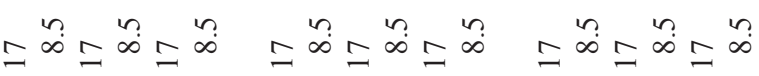
กุด ก -

으으으으우

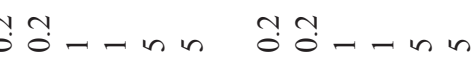

유ㅇㅠㅠ유유 아아아

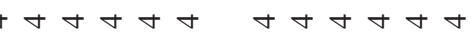

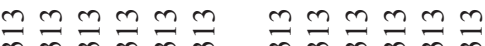

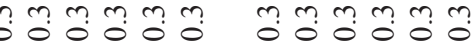

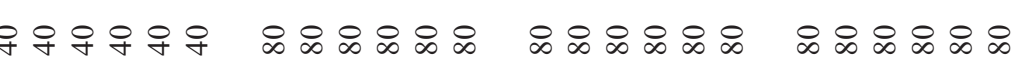

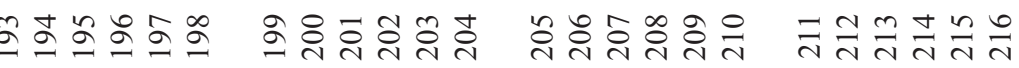


E E

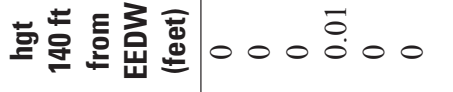

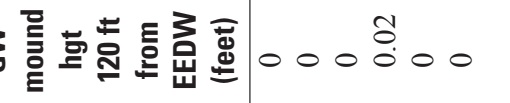

ㅎํㅇํㅇ 훙

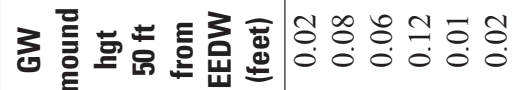

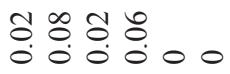

ஜํ.:

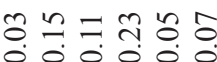

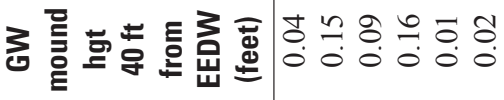

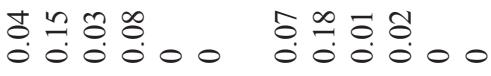

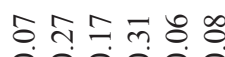

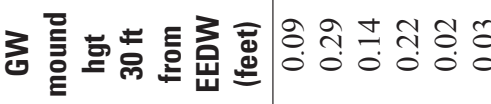

च స़े :

$\frac{3}{2}$ กุ

눔

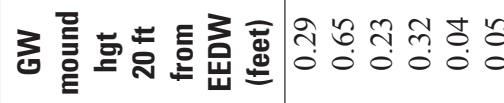

กี

$m \approx n \infty 00$

तै: 0.0000

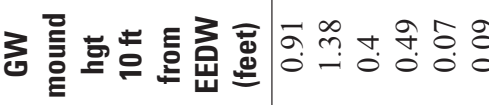

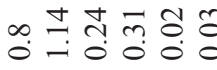

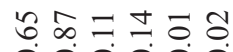

¿̂.

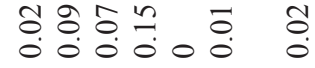

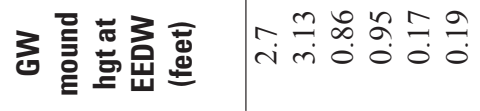

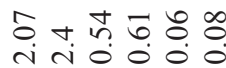

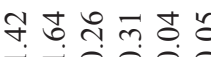

000000

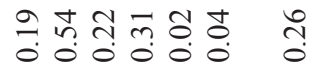

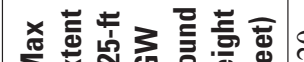

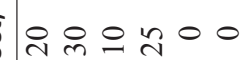

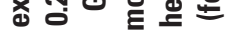

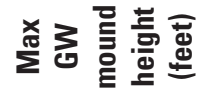

+. $\infty$ o

규융ㅇㅇ

iㅏㅇ--oo

ทำำ

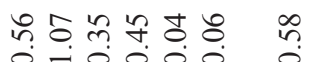

氜 뜨유.

के

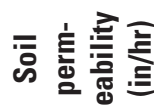

$=\stackrel{n}{\infty}=\stackrel{n}{\infty}=\frac{n}{\infty}$

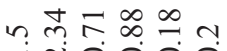

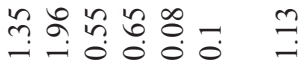

产竞崖

$\cos 2$

言

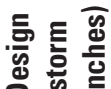

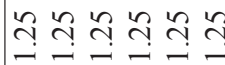

으으으으으으

पे

लंभ प्र है

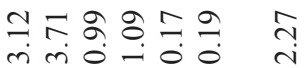

.

䟤

豆㗪

으으으으으으

궁ㅇㅇㅇㅇㅜ -

n워융유

突

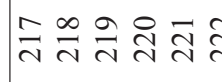

$=\stackrel{n}{\infty}=\stackrel{n}{=}=\frac{n}{\infty}$

$=\stackrel{n}{=}=\stackrel{n}{=\infty}=\stackrel{n}{\infty}$

t우유요

ㅇํำ

กุบ

ํํㅇ.

규유ํํㅠำ

กุ้ กัด

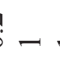

- in in

กุ่ ชุ

으으으으으으

아아아아우우

Aㄷำ

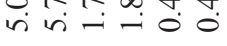

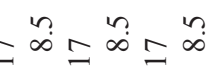

$=\stackrel{n}{=}=\stackrel{n}{\infty}=\infty$

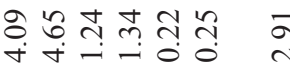

$t+t+t t^{2}$

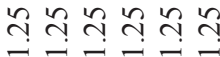

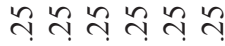

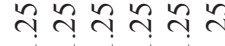

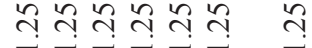

- - -

- -1

으으으으으으

유유유융

규유유유 죽

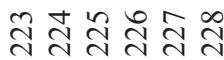

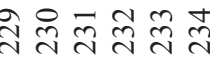

๙ึิ 


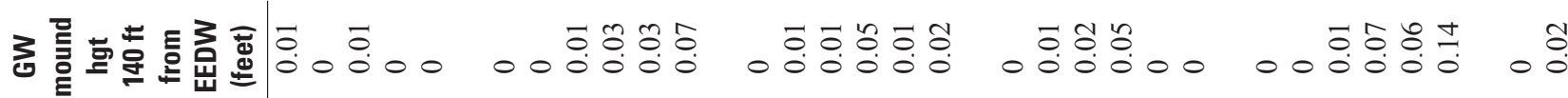

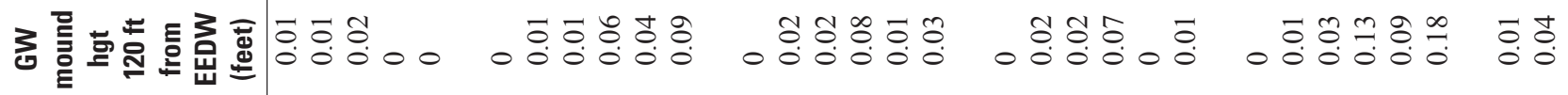

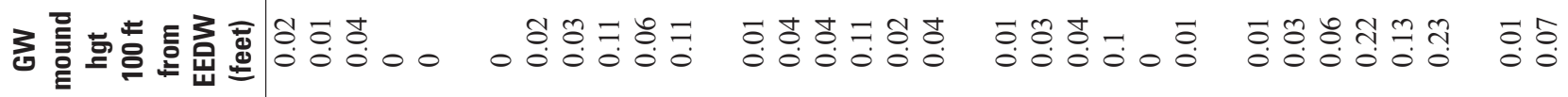

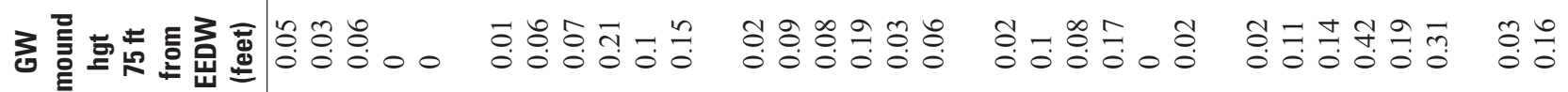

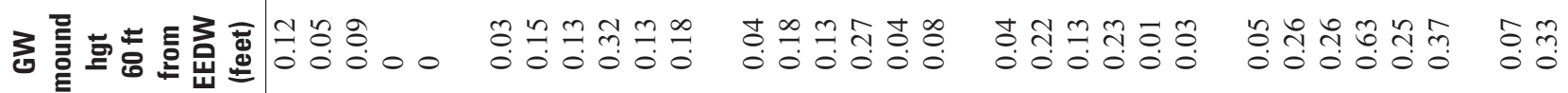

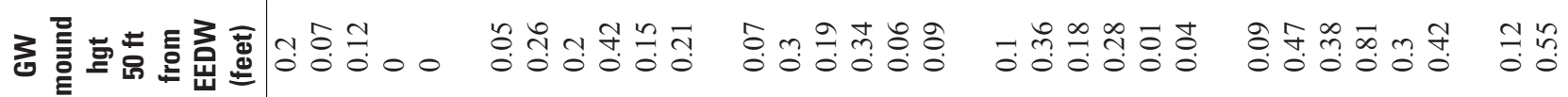

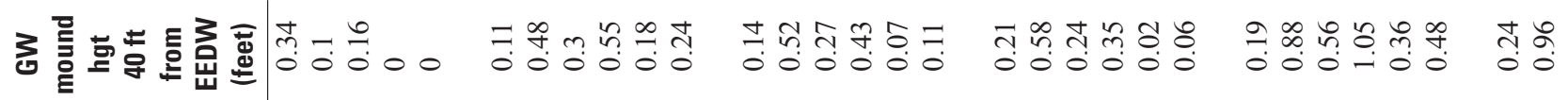

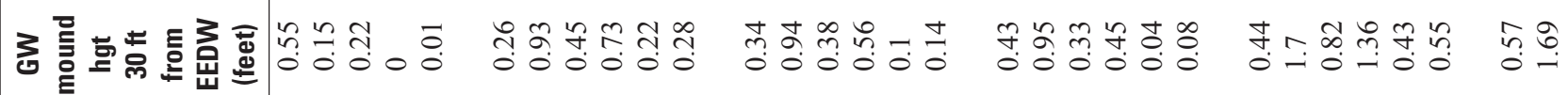

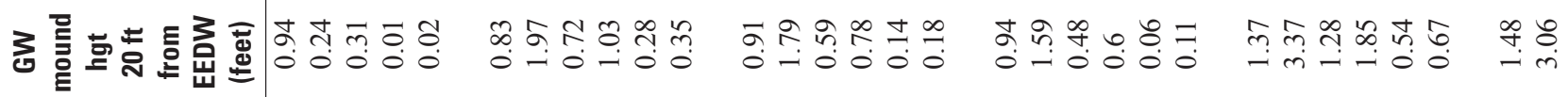

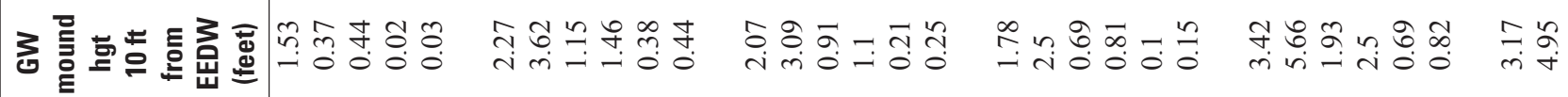

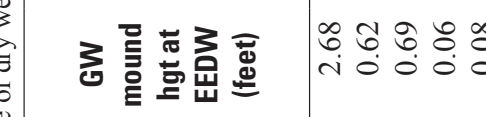
苘

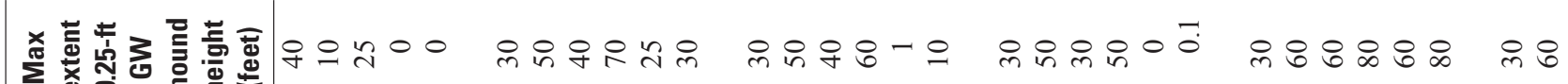

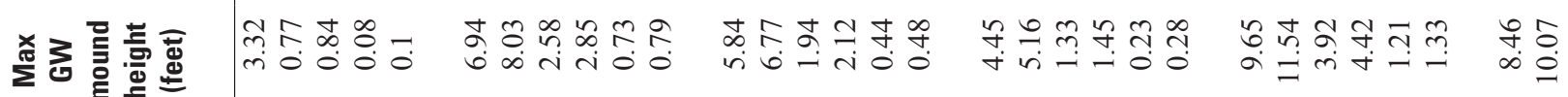

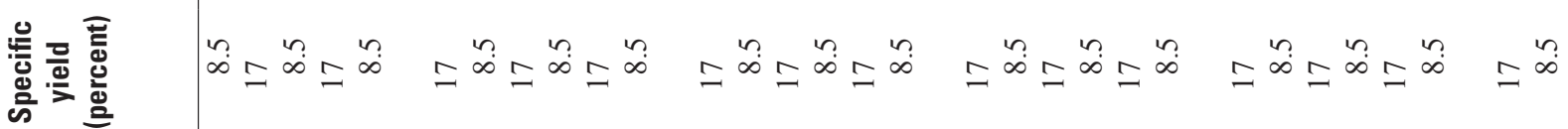

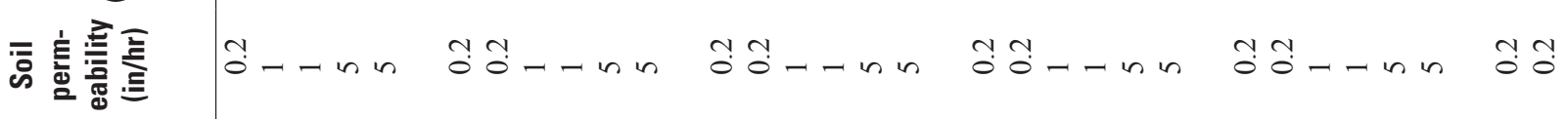

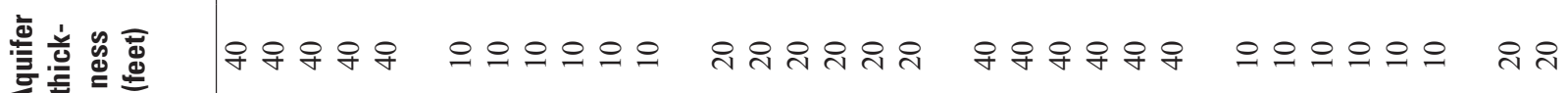
. 告

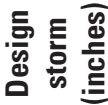

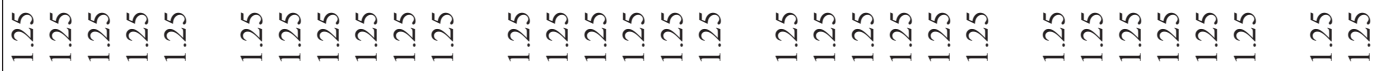

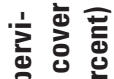
至号兽

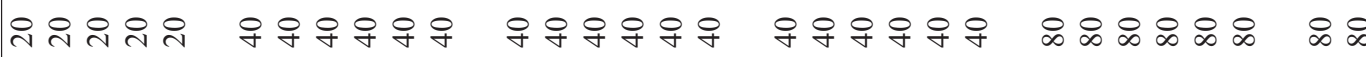
突

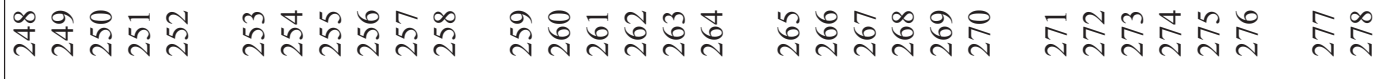




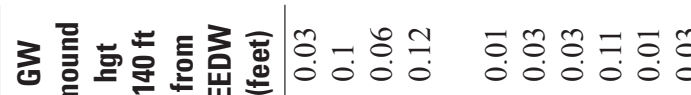

000000000000000000000

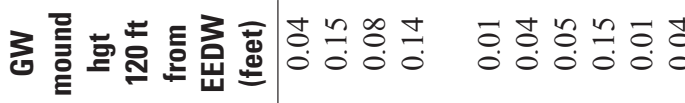

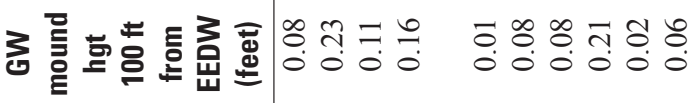

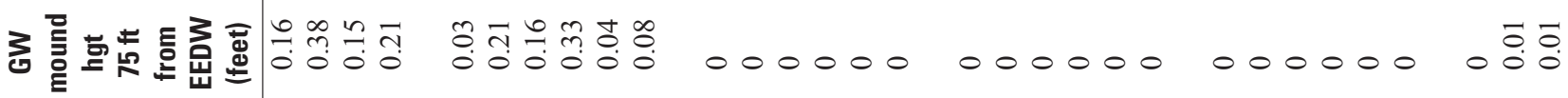

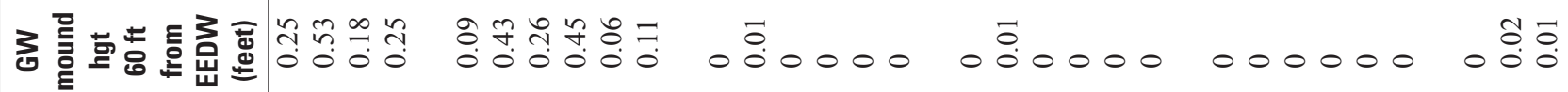

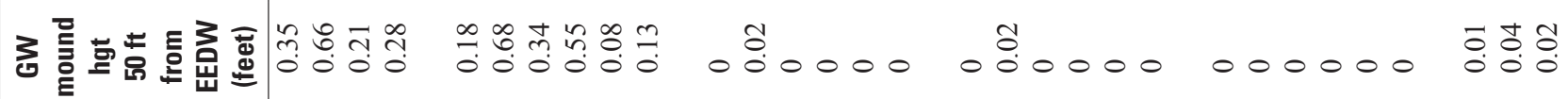

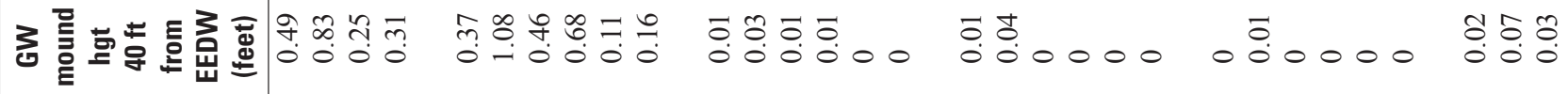

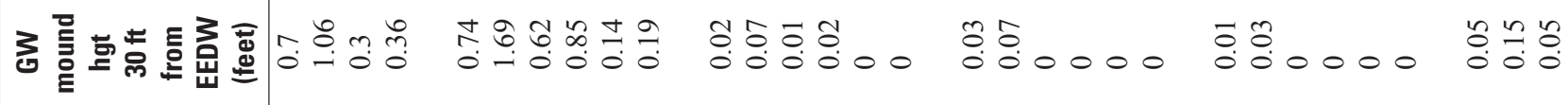

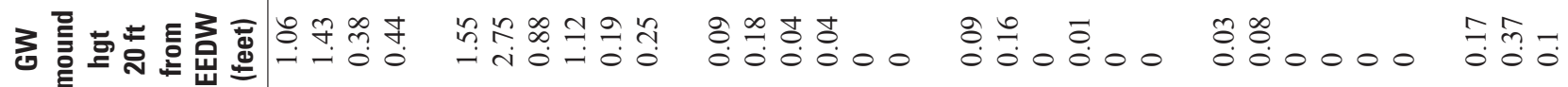

卷辰

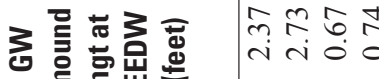

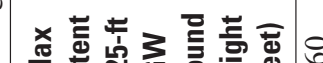

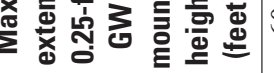

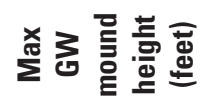

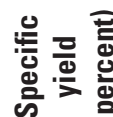

的言高意

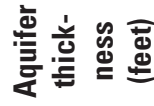

密

홍

的毛

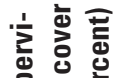

宣哀总

完

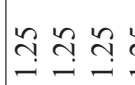

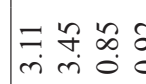

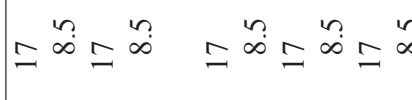

ำ ำ

y- $x$ in in

ํํํำ ิ

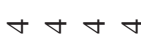

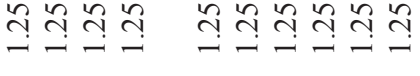

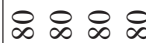

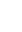

우우아아우우

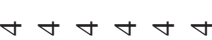

(1)

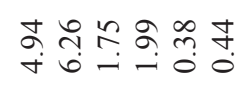

웅요은ㅈ

$B=$ กิ

$=\stackrel{n}{\infty}=\stackrel{n}{\infty}=\infty$

ஃஃஃஃஃ

쉬워 $\underset{\sim}{\infty} \underset{\sim}{\infty}$
ज䏛

mิษ

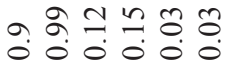

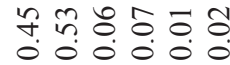

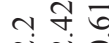

$00-100$

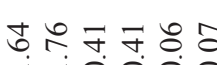

$-10000$

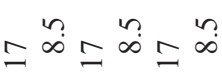

ก)

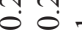

으으으으으으

으으으으으으

$m m m m$

०ै भ?

으으으으으으

으으으으으으

$=\stackrel{n}{\infty}=\stackrel{n}{\infty}=\stackrel{n}{\infty}$

$=\stackrel{n}{=}=\stackrel{n}{=}=\stackrel{n}{\infty}$

$=\infty$

$\frac{1}{3}$

o.

กับ กัด

กุ่ กี่

유유유유앙ㅇㅇ으으으

으으으으으으 으으으으으으 으으으

$\stackrel{m}{m} \stackrel{m}{m} \frac{m}{m} m \frac{m}{m} \quad m m \frac{m}{m} \frac{m}{m} \frac{m}{m} \quad m \frac{m}{m}$

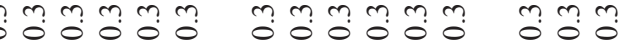

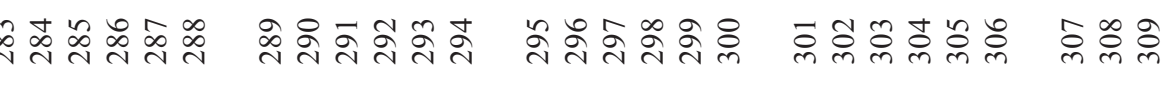




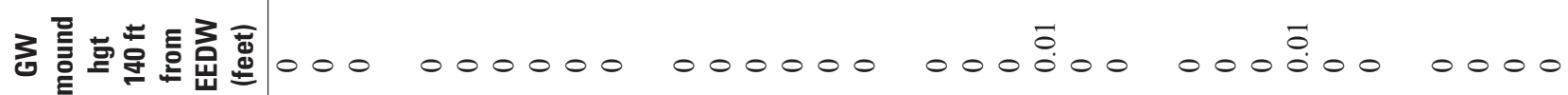

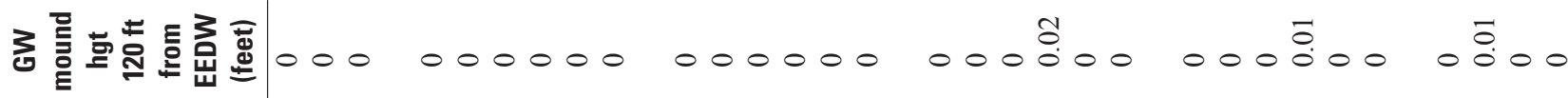

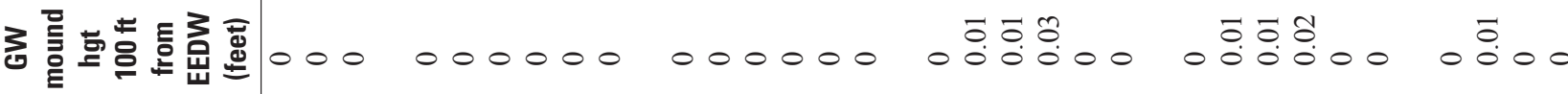

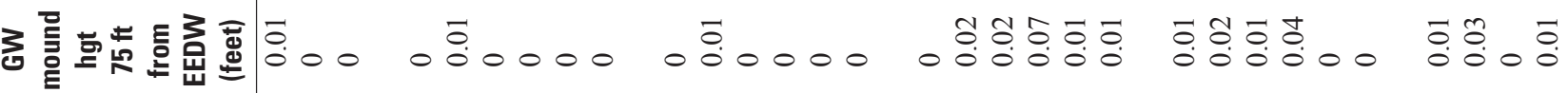

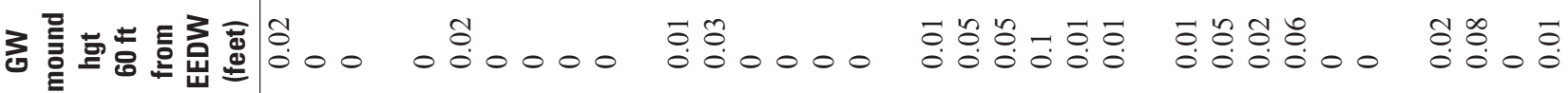

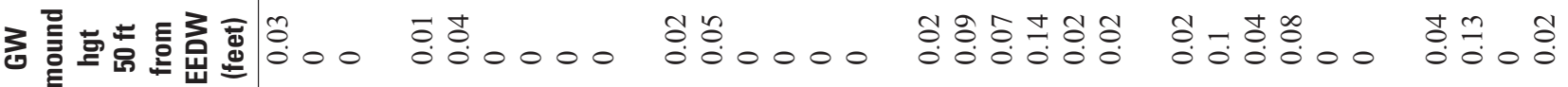

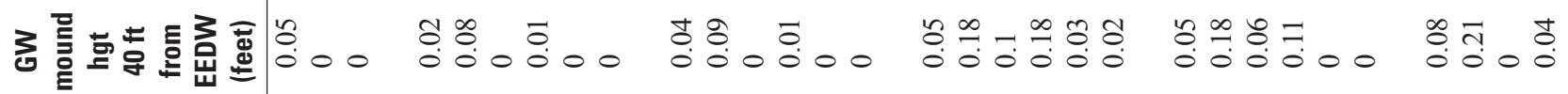

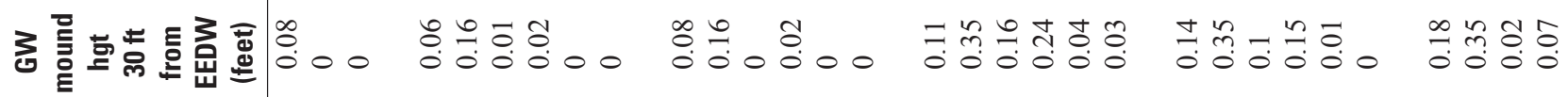

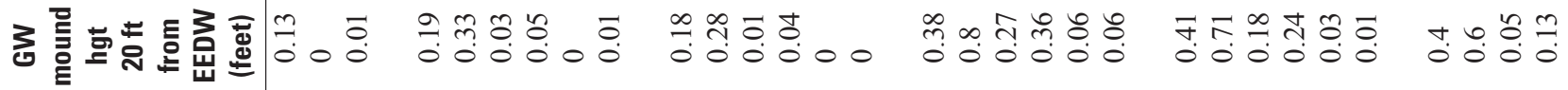

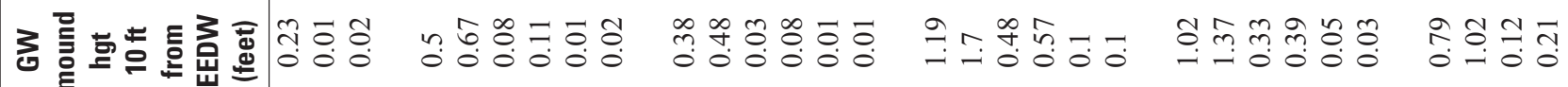

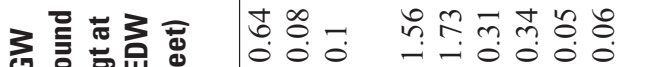

ลิ - ำ ำ ชิ ช

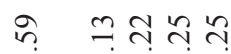

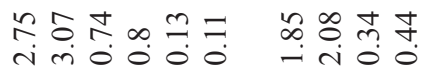

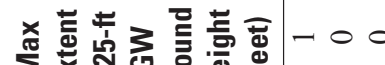

유--00

유융

유유뮤--

쥬융ㅇㅇㅇㅇ

과요-

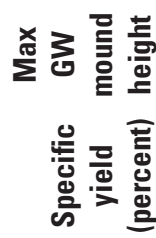

츙

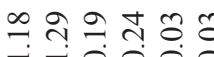

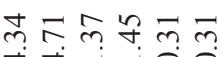

అี่

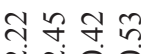

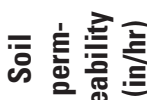

$\stackrel{n}{\infty}=\stackrel{n}{\infty}=\stackrel{n}{\infty}=\stackrel{n}{=}=\frac{n}{\infty}$

$=\stackrel{n}{\infty}=\stackrel{n}{\infty}=\stackrel{n}{\infty}$

$=\stackrel{n}{=}=\infty n^{n}=\infty$

$=\stackrel{n}{=}=\stackrel{n}{\infty}=\stackrel{n}{=}$

$=\stackrel{n}{=\infty}=\stackrel{n}{=}$

离竞免要

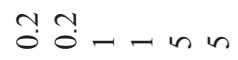

กับ กุด

กุํา

กุ้

กุํา กุด -

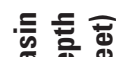

으으으 유유슈ํํ

아아아워워우

으으으으으으

으유유유유

아아앙ㅇ

으으 으으으으으 으으으으으 으으으으으 으으으으으 으으으

衰

$\frac{m}{m} \stackrel{m}{m} \frac{m}{m}$

$m \frac{m}{m} \frac{m}{m} \frac{m}{m}$

$m \frac{m}{m} m \frac{m}{m}$

$m \frac{m}{m} \frac{m}{m} \frac{m}{m}$

$\stackrel{m}{m} \frac{m}{m} \frac{m}{m} \frac{m}{m} \stackrel{m}{m} \frac{m}{m}$

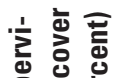

宣哭尊

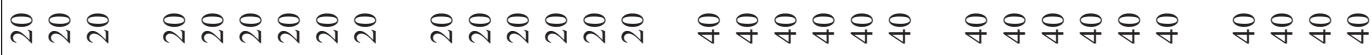

突

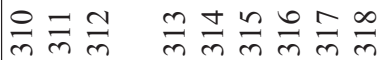

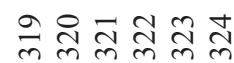

๗ँ्त̄

जస్లి

હે 


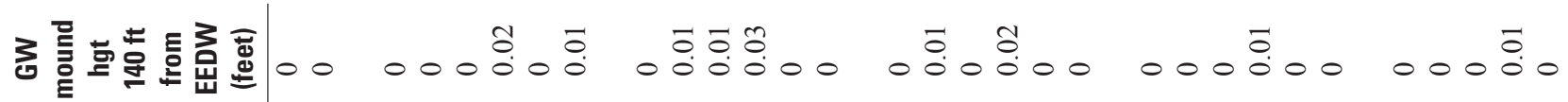

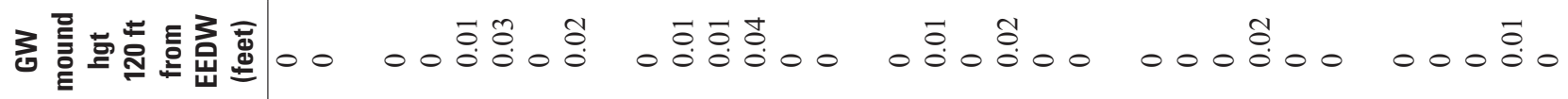

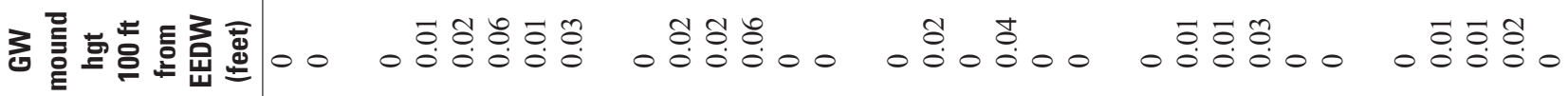

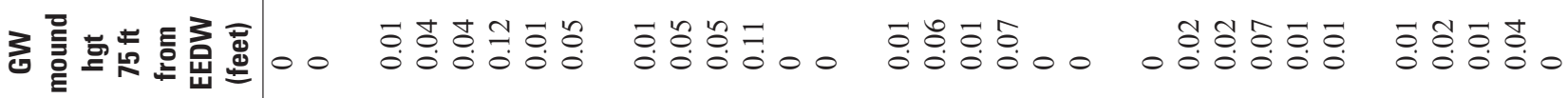

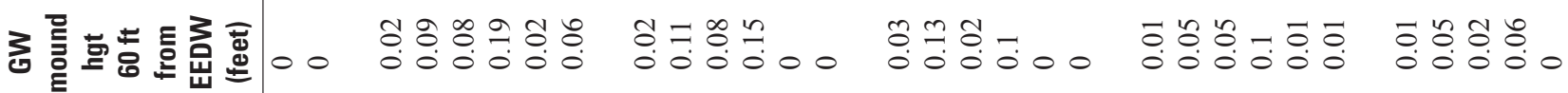

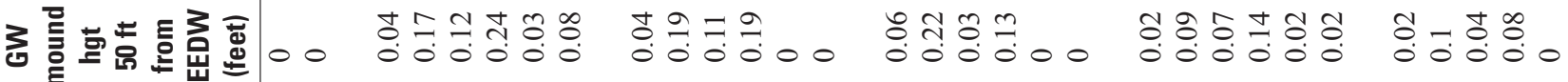

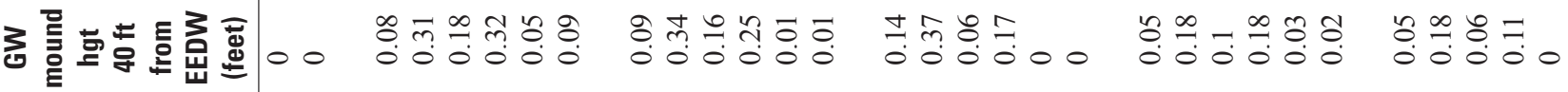

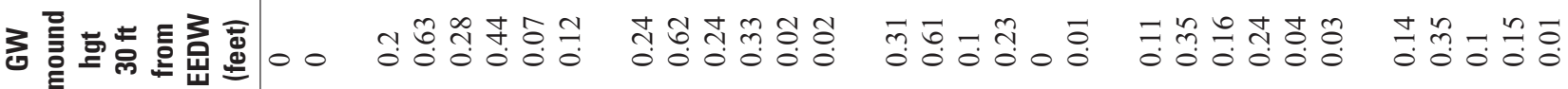

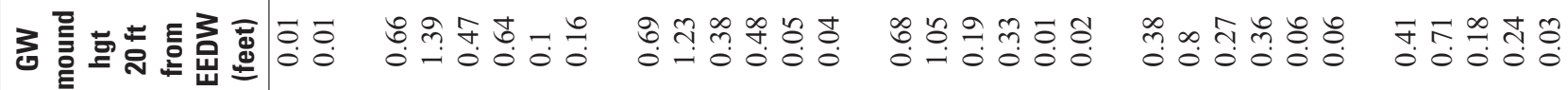

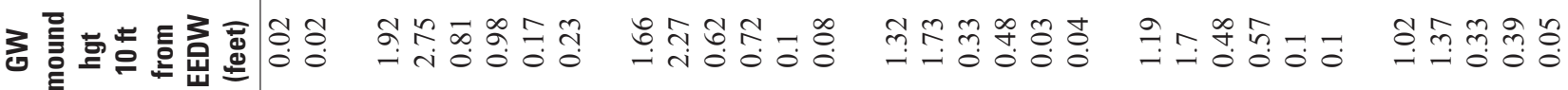

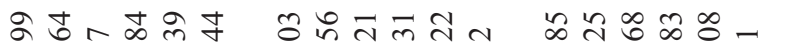

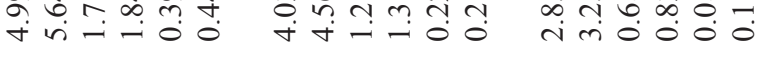

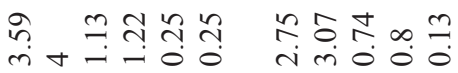

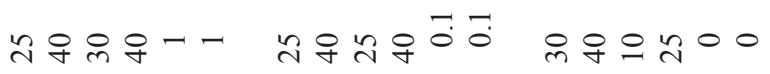

ㅇํํำㄴ- 유융ㅇำ

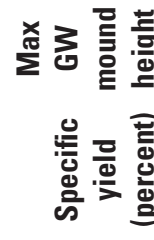

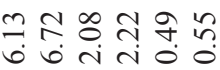

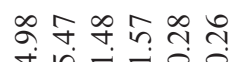

ก $\infty \stackrel{\infty}{\infty} \stackrel{m}{a}=$

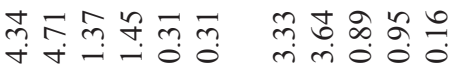

的言竞焉

$=\stackrel{n}{\infty}=\infty \infty_{\infty}^{n}=\infty$

$=\stackrel{n}{=}=\stackrel{n}{\infty}=\stackrel{n}{\infty}$

$=\stackrel{n}{=}=\stackrel{n}{\infty}=\stackrel{n}{\infty}$

$=\stackrel{n}{=}=\stackrel{n}{\infty}=\stackrel{n}{=}$

$=\stackrel{n}{=\infty}=\stackrel{n}{\infty}=$

产冚总总

กุํา ชุ

กับ ของ

กับ

กุก

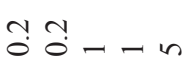

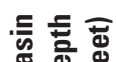

웅

으으으으으으

ิํํำ ㅇํำ

아아앙ㅇㅇㅇㅇ

으으으으으으

위유유유

으으으으으오

으으으으으으

으으으으으으

으으으으으으 으으으으으

홍 홍

$\frac{m}{m} \frac{m}{m} \frac{m}{m} \frac{m}{m} \frac{m}{m} \frac{m}{m}$

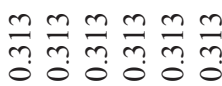

$m \frac{m}{m} \frac{m}{m} \frac{m}{m}$

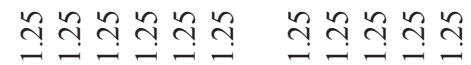

完言

宣哭总

৯৯ঃ৯ঃ

$\triangleright \triangleright \triangleright \triangleright \triangleright \triangleright$

$\triangleright \triangleright \triangleright \triangleright \triangleright \triangleright$

으으으으으으 으으으으으 


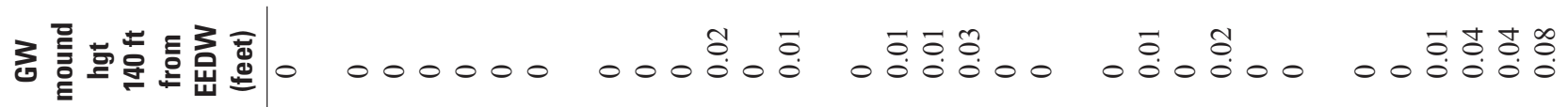

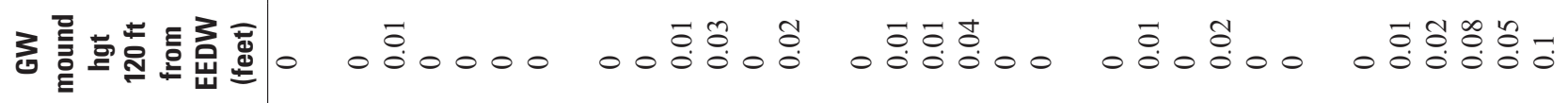

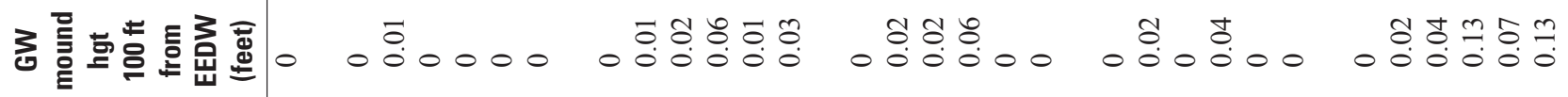

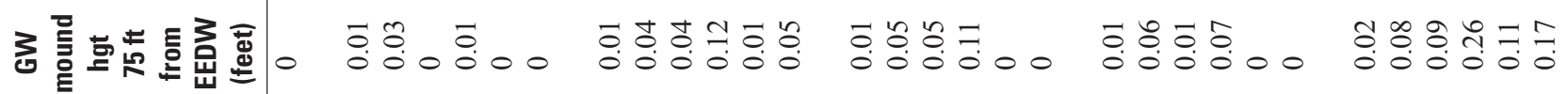

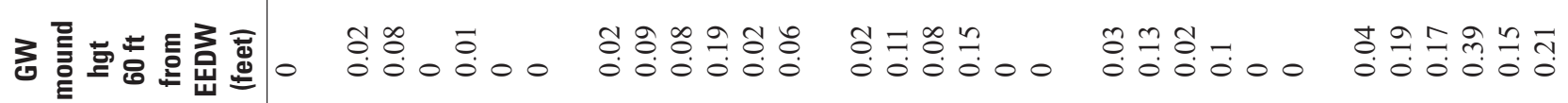

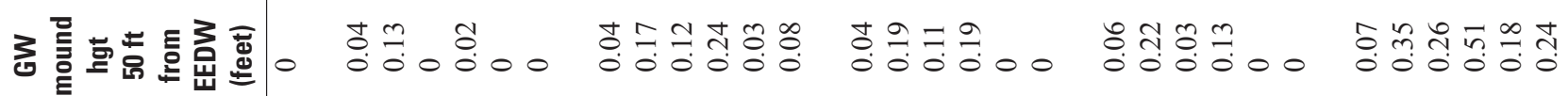

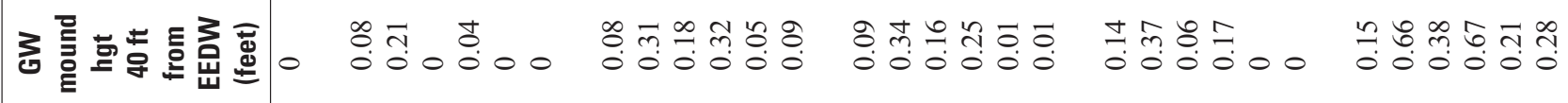

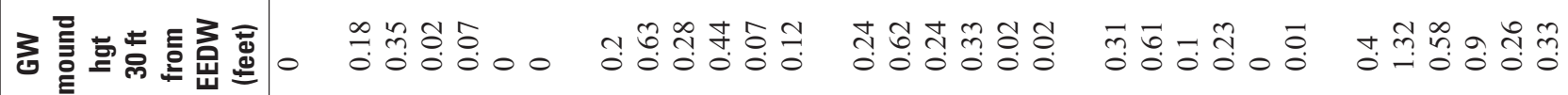

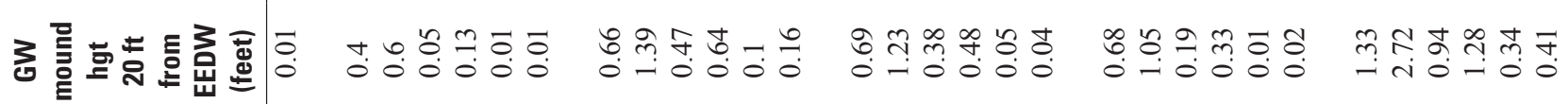

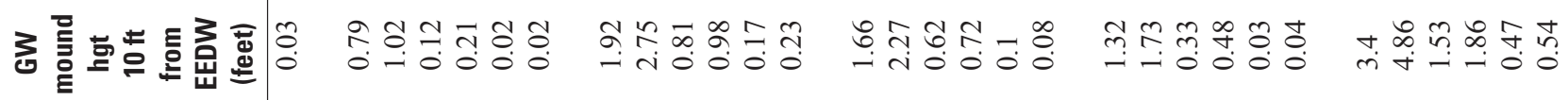

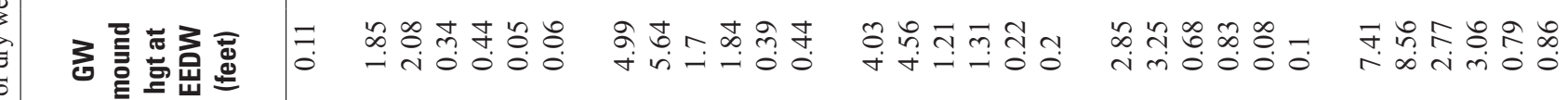

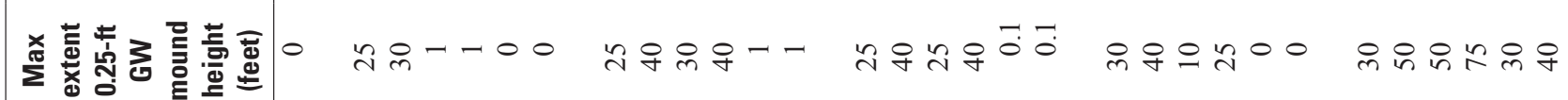

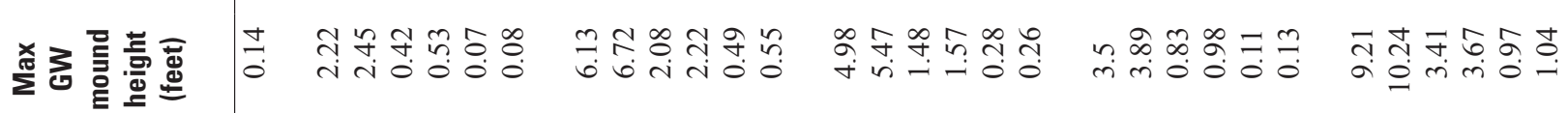

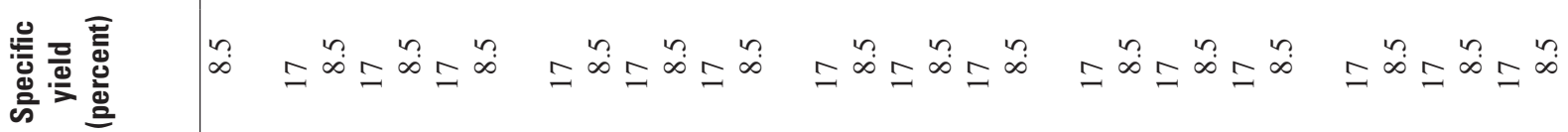

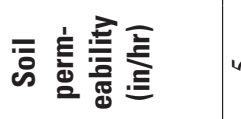

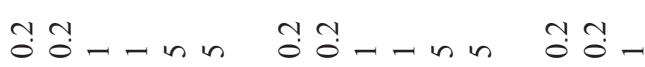

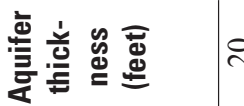

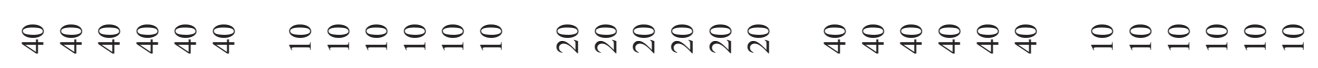

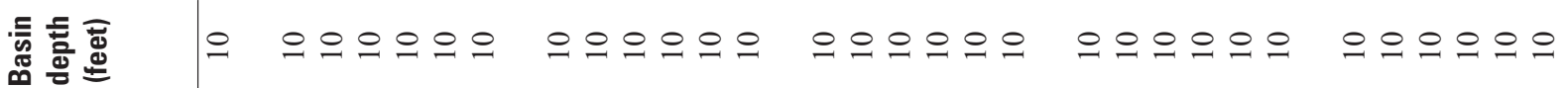

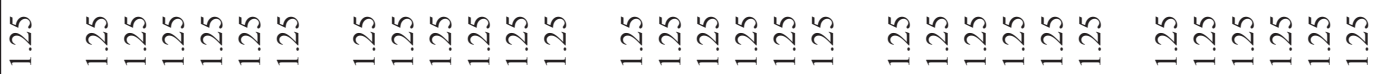

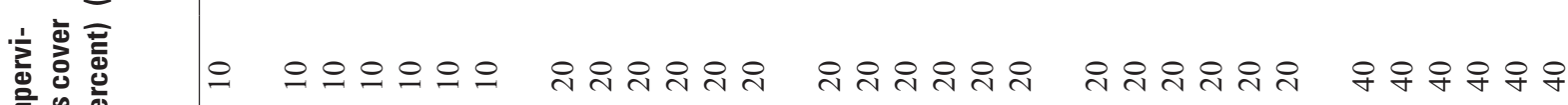
至哭总

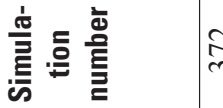

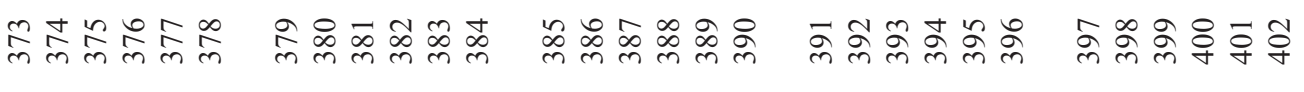




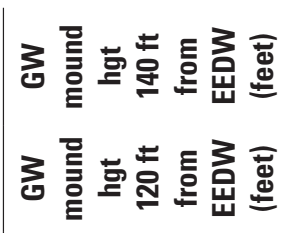

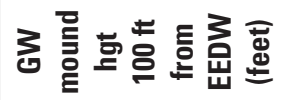

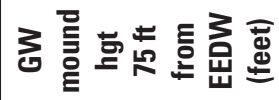

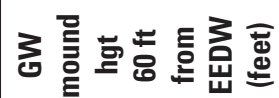

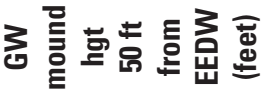

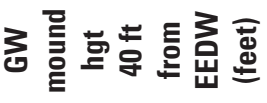

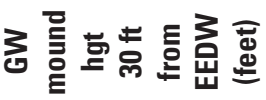

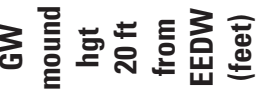

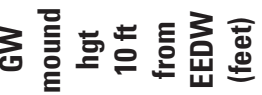

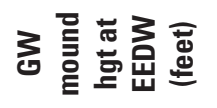

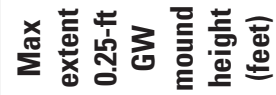

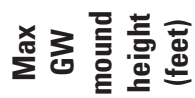

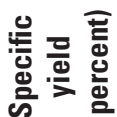

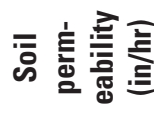

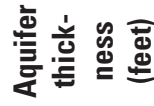

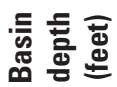

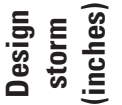

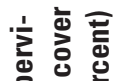

트 응 흔

흘 흘 흘
- $\overrightarrow{0}: \overrightarrow{0}: \stackrel{0}{0}: \overrightarrow{0} \cdot \overrightarrow{0}$

○ 둥유.

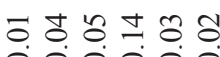

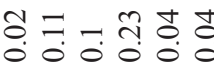

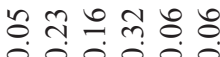

$\hat{\theta}+\hat{y}^{\infty}$

0.000000

고유ํำ

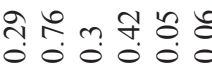

웅 웅 8

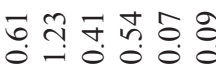

$m+2059$

i i

m.

$\stackrel{\infty}{\circ}=$ 구 + $\stackrel{\infty}{\infty}$

4.

กุ

onitió

잉으아요으으

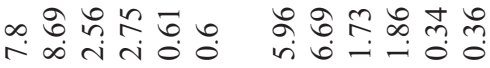

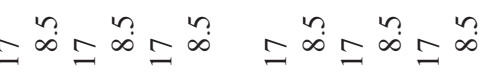

$\pi \frac{1}{2}$

1.०

주슈슈츄ำ

$\pi)^{2}$

강

(1)

으으으으으으

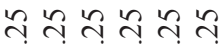

- - - -

우의의의

孚荤崇宗宗学

ๆ ำ $\infty$ 웅

त लं०

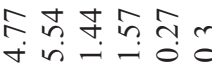

dided-

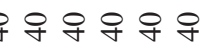

으으으으으으

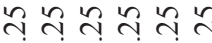

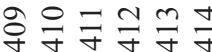

요요요

F

I里的-

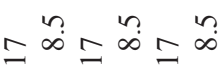

ㄱำ

ag- - in

กูก อี่

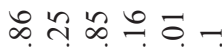

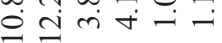

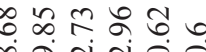
oि तis:

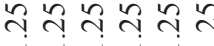

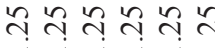

- - -

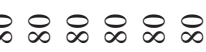

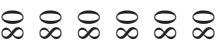


For additional information, write to:

Director

U.S. Geological Survey

New Jersey Water Science Center

Mountain View Office Park

810 Bear Tavern Rd., Suite 206

West Trenton, NJ 08628

or visit our Web site at:

http://nj.usgs.gov/ 
